\title{
THE GUATEMALAN EARTHQUAKE OF FEBRUARY 4, 1976, A PRELIMINARY REPORT
}

This study was conducted by the U.S. Geological Survey in cooperation with the Government of Guatemala and with partial support from the Organization of American States

GEOLOGICAL SURVEY PROFESSIONAL PAPER 1002

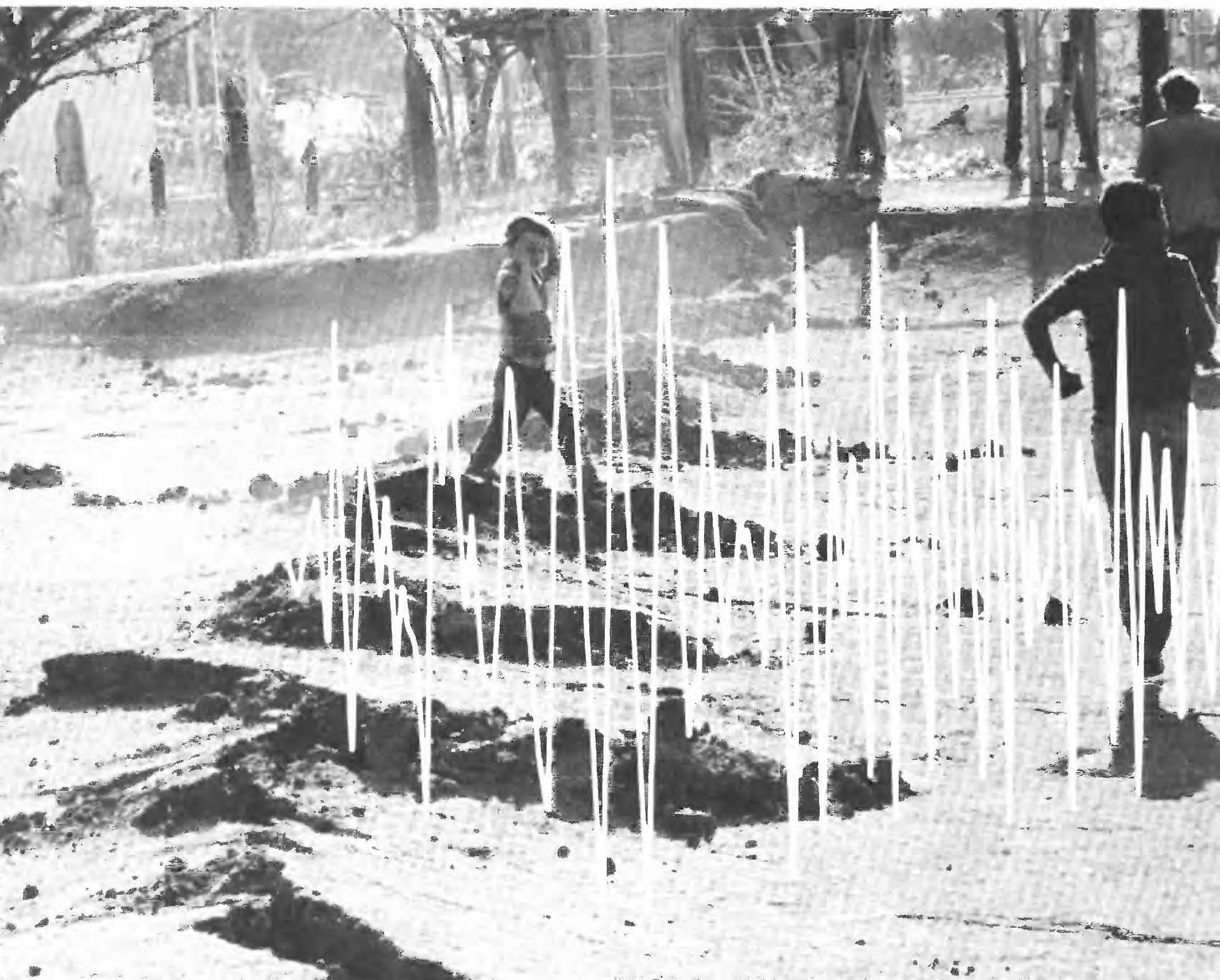




\title{
THE GUATEMALAN EARTHQUAKE OF FEBRUARY 4, 1976, A PRELIMINARY REPORT
}

\author{
A. F. ESPINOSA, EDITOR
}

GEOLOGICAL SURVEY PROFESSIONAL PAPER 1002

A preliminary report of a series of closely related studies of the destructive Guatemalan earthquake of February 4, 1976

This study was conducted by the U.S. Geological Survey in cooperation with the Government of Guatemala and with partial support from the Organization of American States
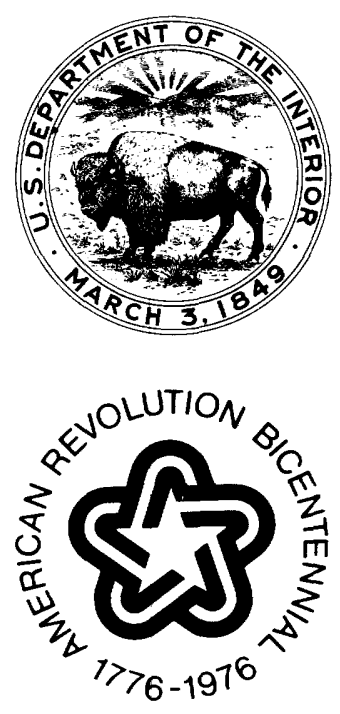


\title{
UNITED STATES DEPARTMENT OF THE INTERIOR
}

\author{
CECIL D. ANDRUS, Secretary
}

\section{GEOLOGICAL SURVEY}

\author{
V. E. McKelvey, Director
}

First printing 1976

Second printing 1977

\section{Library of Congress Cataloging in Publication Data}

The Guatemalan earthquake of February 4, 1976.

(Professional paper - U.S. Geological Survey; 1002) “The study was conducted by the U.S. Geological Survey in cooperation with the Government of Guatemala and with partial support from the Organization of American States."

Bibliography: p.

1. Earthquakes--Guatemala. I. Espinosa, A. F. II. Series: United States. Geological Survey. Professional paper; 1002 .

QE535.2.G9G8

$551.2 ' 2$ '097281

$76-608166$

For sale by the Superintendent of Documents, U.S. Government Printing Office Washington, D.C. 20402

Stock Number 024-001-02858-1 


\section{CONTENTS}

Glossary --.- Page

Symbols and abbreviations

Abstract -_-

Introduction -

Acknowledgments -

Tectonic setting and seismicity, by William Spence and Waverly Person

Introduction -

Seismicity -

Historical seismicity - _.

Tectonic history of the Caribbean-North American plate boundary -

The Caribbean-Cocos-North American plate triple junction

Instrumentally recorded seismic activity prior to the main event, by David $H$.

Harlow -

Introduction _.

Seismically active areas in Guatemala _... 12

Distribution of S-P times _._.

Seismic activity in the vicinity of Guatemala City

Summary _.

Main event and principal aftershocks from teleseismic data, by Waverly Person, William Spence, and James W. Dewey _... 17

Main event source parameters from teleseismic data, by James W. Dewey and

Bruce R. Julian - 19

Introduction -

Focal mechanism -..

Seismic moment _...

Source dimensions, displacement, stress drop, and direction of fault propagation -

Future earthquakes on the Motagua fault system

Strong-motion recordings of the main event and February 18 aftershock, by

Charles F. Knudson

Introduction - . -

Seismic instrumentation

Seismoscope records of main event

Strong-motion accelerogram of February 18 aftershock

San Salvador accelerograph of main event

Aftershocks from local data, by Charley J. Langer, Jean P. Whitcomb, and

Arturo Aburto Q

Introduction -........

Instrumentation and field procedure -

Data and analysis

Results and discussion _...

Geologic effects, by George Plafker, Manuel G. Bonilla, and Samuel B. Bonis....-

Introduction _...

The main fault -

Relationship of faulting to damage

Secondary faults

Mixco zone -....

Villa Linda-Castañas zone

Incienso-Santa Rosa zone

Regional tectonic relations of earthquake faults _......

Landslides - - . . - .

Landspreading, fissuring, subsidence, and sand mounds _..................

Volcanic activity 
Intensity distribution and source parameters from field observations, by Alvaro

F. Espinosa, Raul Husid, and Antonio Quesada -

Introduction -.....-.

Casualties and damage -

Intensity distribution in Guatemala

Distribution of adobe damage -

Intensities in Guatemala City

Intensities in neighboring countries -......-

Ground motion at intermediate distances .

Source parameters from field observations -

Damage and engineering implications, by Raul Husid, Alvaro F. Espinosa, and

Antonio Quesada .....

Introduction -...-

Earthquake-resistant design practice in Guatemala

Types of structures -...

Damage survey --1-0-1-

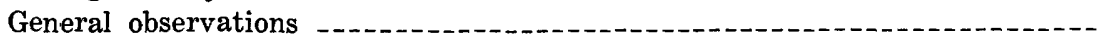

Structural engineering observations in Guatemala City, by Karl V. Steinbrugge --

Introduction

Life loss and construction

Design and construction practices -

Specific damage observations -

References cited --

Chronological historical record of damaging earthquakes in Guatemala, 15261976

Page

52

52

52

52

58

61

61

62

62

67

67

67

67

67

70

80

80

80

80

81

\section{ILLUSTRATIONS}

\section{Figures 1-4. Maps showing-}

1. Guatemala, Central America

2. Tectonic setting of the Caribbean plate

3. Regional seismicity, 1902-74

4. Historical seismicity of Guatemala

5. Diagram of tectonic evolution of the Caribbean plate

6. Diagram of projected tectonic configuration of the Caribbean plate in $50 \mathrm{~m} . \mathrm{y}$

7. Map of station locations of the 1973 Guatemalan seismograph network

8. Guatemalan seismicity map, 1945-75 _.

9. Histogram showing distribution of $S-P$ time intervals

10. Map showing epicenters and known faults within the $\mathbf{1 9 7 3}$ seismic network

11. Location of epicenters of the main event and principal aftershocks

12. P-wave focal mechanism solution -...-

13. Azimuthal variation of the $G$-wave displacement spectral density

14. Effect of source propagation on G-wave amplitudes -.-.-.--

15. Location of strong-motion field network

16. Seismoscope plate, roof of University administration building, Guatemala City -

17. Seismoscope plate, ground floor of University administration building, Guatemala City

18. Deconvolved seismoscope recording _._._._. 28

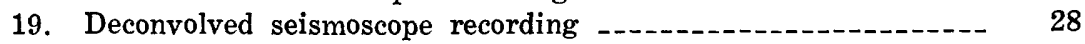

20. Accelerogram of aftershock, IBM building, Guatemala City -- 28

21. Sample seismograms from the 1976 temporary seismic network 32

22. Map of aftershock epicenters from 1976 temporary seismic network -...-

23. Map showing regional setting of Motagua and Mixco faults --- 
Figures 24-28. Aerial photographs showing-

24. Displaced furrows on the Motagua fault trace, farmland west of Cabañas

25. Displaced furrows on Motagua fault trace, farmland west of El Progreso

26. En echelon offset, in a soccer field, of the Motagua fault trace-Gualán -

27. Most easterly, locally visited trace of the Motagua fault - - -

28. Subinal, Guatemala

29. Map showing zones of secondary faults and locations discussed in text

30-32. Photographs showing-

30. Fault displacement in Guatemala City

31. Fault damage to house in Guatemala City ....-..-

32. Fault damage to house in Guatemala City, vertical dis-

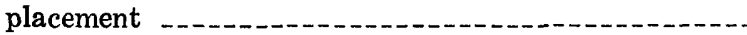

33. Map showing extent of earthquake-induced landslides

34. Photograph of landslides in road cut, San Cristobal, Guatemala

35-38. Aerial photographs showing-

35. Landslides north of Chimaltenango, Guatemala ......-

36. Landslide in gully, Guatemala City

37. Landslide-dammed lake, Río Pixcayá _............

38. Ground cracks and sand mounds in unconsolidated alluvium near Quebradas

39. Photograph of linear sand mounds and craters, Motagua River Valley

40. Map showing location of intensity-questionnaire sampling distribution in Guatemala

41. Photograph of landslide obstructing road between Guatemala City and El Progreso

42. Photographs of damage to railroads at Gualán, El Jicaro, Puerto Barrios wharf, and fault trace near Las Ovejas

43. Map showing Modified Mercalli intensity distribution in Guatemala

44. Schematic diagram of slip progression and effect on wave amplitudes due to a moving dislocation

45. Contour map of damage to adobe-type structures

46-57. Photographs showing-

46. Intensively damaged towns of Joyabaj, Comalapa, Tecpan, and San Martin Jilotépeque -.......-

47. Wharf destroyed by earthquake at Puerto Barrios ---

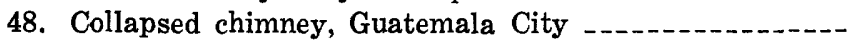

49. Head of a landslide, Guatemala City

50. Overthrown marble statues, Guatemala City .........

51. Distortion and severe damage to wood construction, Puerto Barrios

52. Collapsed second story at Colegio San Javier, Guate-

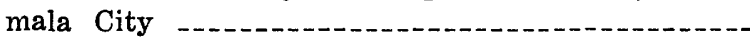

53. Partial collapse of three-story reinforced-concrete structure, Guatemala City

54. Collapsed church, Guatemala City

55. Collapsed third story of Hotel Terminal, Guatemala

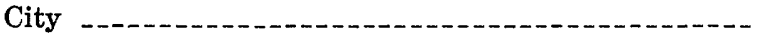

56. Collapsed gas-station structure, Guatemala City -..-

57. Collapsed water tower, Guatemala City _.............

58. Drawings of collapsed water tower shown in figure 59

59. View of collapsed water tower, Villanueva 74

60. View of collapsed grain silo, Villalobos _._. 74

61. Drawing of cracked sedimentation tank 75 
FIGURES 62-76. Photographs showing-

62. Damage to reinforced masonry, Colonia San Francisco,

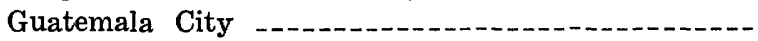

63. Fault trace across San José Rosario subdivision, Guatemala City -.-.-.

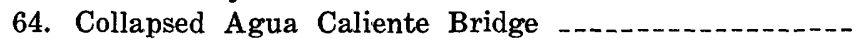

65. Damaged Benque Viejo Bridge -.........................

66. Column failure in reinforced-concrete framed structure,

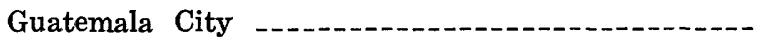

67. Partial collapse of protruding structure on 11-story Cruz Azul building, Guatemala City ...........

68. Collapsed single-story reinforced-concrete framed building, Licorera Mixco, Mixco -................

69. Heavily damaged adobe houses, Antigua and Guate-

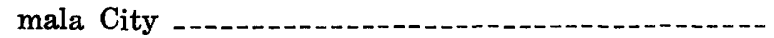

70. Damage to flat beams and slab in a reinforced-concrete building, Guatemala City _...................

71. Undamaged steel-frame Finance Ministry Building,

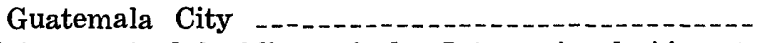

72. Main terminal building of the International Airport, Guatemala City -...

73. Partially collapsed third story of Hotel Terminal, Guatemala City -....

74. Collapsed column in Hotel Terminal, Guatemala City--

75. Collapsed second story, Catholic Boys School, Guatemala City

76. Column failure in second story, Catholic Boys School, Guatemala City

\section{TABLES}

TABLE 1. Coordinates and magnifications of seismograph stations --.--

2. Number of events each month originating from the central fault system compared with the number of all regional events

3. Epicenter location of aftershocks

4. Distance, azimuths, and spectral density for G-waves -......

5. List of seismograph stations occupied during this study

6. Aftershocks of the main event located by the temporary seismograph network

7. Characteristics of earthquake fractures along the Motagua fault

8. Casualties and damage, Departmentwide -

9. Casualties and damage by municipality

10. Felt area for Modified Mercalli intensities VI and higher -.--

11. Damage to adobe type structures 


\section{GLOSSARY}

Accelerogram. A record made by an acceleroyneter, showing the amplitude of acceleration as a function of time.

Accelerometer. An instrument designed to record ground accelerations.

Aftershock. Secondary small magnitude earthquakes which follow the main event.

Amplification. Seismic-wave amplification is a relative measurement of the ratios of seismic waves recorded on alluvium to those recorded on crystalline rock. In the frequency domain is the ratio obtained from two stations for a selected spectral component.

Bar. $10^{6}$ dyne $\mathrm{cm}^{-2}$.

Body-wave magnitude $\left(m_{b}\right)$. A measure obtained from the amplitude and period of $\mathrm{P}$ - or $\mathrm{S}$-waves at teleseismic distances.

Colegio. School.

Deconvolved. Division of a time series into a new time series plus a shorter wavelet. Usually the wavelet has a physical significance such as the impulse response of a system.

Departamento. A subdivision of the Republic of Guatemala geographical territories. Similar to States in the United States.

Department. See Departamento.

Energy $(E)$. A measure of the seismic energy released by an earthquake. Dimensions are in ergs. This quantity $E$ is often given in empirical relationships as functional dependent on magnitude.

Epicenter. The point on the Earth's surface vertically above the hypocenter or point of origin of an earthquake.

Fracture zone. An elongated complex of geologic features, mostly faults, thought to represent the contact between major geologic units which are moving relative to each other.

G-waves. Seismic surface waves impulsive and slightly dispersed are called G-waves (mantle Love waves). The suffix 2, 3, 4, and so on indentifies the great circle path of propagation. Odd numbers identify the short great circle path from epicenter to station G1; G3 is that epicentral distance plus $360^{\circ}$. Even numbers identify waves that propagate in opposite azimuths.

Hazardous structure. An unsafe structure because of poor design, poor construction, defects in foundations, or damaged due to faulting or vibrational effects of an earthquake.

HYPO71. The identification of a software package which computes the hypocenter parameters of an earthquake.

Hypocenter. The point of origin of an earthquake, where rupture begins and from which seismic waves originate.

Intensity. A numerical subjective index describing the effects of an earthquake on man, on structures, and on the Earth's surface. The Modified Mercalli scale of 1931 with ratings from I to XII, as defined below, is used in the United States (modified from Richter, 1958):
Modified Mercalli intensity scale

I. Not felt, except by a very few under specially favorable circumstances.

II. Felt only by a few persons at rest, especially on upper floors of buildings. Delicately suspended objects may swing.

III. Felt quite noticeably indoors, especially on upper floors of buildings, but many people do not recognize it as an earthquake. Standing motorcars may rock slightly. Vibration like passing truck. Duration estimated.

IV. During the day, felt indoors by many; outdoors by few. At night some awakened. Dishes, windows, and doors disturbed; walls make creaking sound. Sensation like heavy truck striking building. Standing motorcars rocked noticeably.

V. Felt by nearly everyone, many awakened. Some dishes, windows, and so on broken; a few instances of cracked plaster; unstable objects overturned. Disturbance of trees, poles, and other tall objects sometimes noticed. Pendulum clocks may stop.

VI. Felt by all, many frightened and run outdoors. Some heavy furniture moved; a few instances of fallen plaster or damaged chimneys. Damage slight.

VII. Everyone runs outdoors. Damage negligible in buildings of good design and construction; considerable in poorly built or badly designed structures. Some chimneys broken. Noticed by persons driving motorcars.

VIII. Damage slight in specially designed structures; considerable in ordinary substantial buildings, with partial collapse; great in poorly built structures. Panel walls thrown out of frame structures. Fall of chimneys, factory stacks, columns, monuments, walls. Heavy furniture overturned. Sand and mud ejected in small amounts. Changes in well water. Persons driving motorcars disturbed.

IX. Damage considerable in specially designed structures; well-designed frame structures thrown out of plumb; great in substantial buildings, with partial collapse. Buildings shifted off foundations. Ground cracked conspicuously. Underground pipes broken.

$\mathrm{X}$. Some well-built wooden structures destroyed; most masonry and frame structures destroyed with foundations; ground badly cracked. Rails bent. Landslides considerable from river banks and steep slopes. Shifted sand and mud. Water splashed (slopped) over banks.

XI. Few, if any, masonry structures remain standing. Bridges destroyed. Broad fissures in ground. 
Underground pipelines completely out of service. Earth slumps and land slips in soft ground. Rails bent greatly.

XII. Damage total. Waves seen on ground surfaces. Lines of sight and level distorted. Objects thrown upward into the air.

Isoseismals. Contour lines of equal intensity.

Left-lateral movement. A horizontal movement in which the block across the fault from the observer has moved to the left.

Love waves. A type of surface wave.

Magnitude $\left(M_{L}, m_{b}, M_{S}\right)$. A quantity characteristic of the total energy released by an earthquake. The "intensity" rating, as contrasted to magnitude, describes its effects at a particular place. Richter (1958) devised the logarithmic magnitude scale, which is in terms of the motion which would be measured by a standard type of seismograph located $100 \mathrm{~km}$ from the epicenter of an earthquake. $\mathrm{M}_{\mathrm{L}}$ is the magnitude determined from local recordings, $m_{b}$ is known as body-wave magnitude, and $M_{s}$ as a surface-wave magnitude.

Main event. Refers to the main earthquake.

Meizoseismal area. The area within the isoseismals of higher Modified Mercalli intensity ratings.

Modified Mercalli. See Intensity.

Particle displacement. The difference between the initial position of a soil particle and any later position.

Particle velocity. The time rate of change of particle displacement.

Phase. Any change of frequency in the seismogram of an earthquake. The seismograph responds to the motion of the ground and makes a seismogram. The seismogram is a line that is related to the motion of the Earth in any one chosen direction. The principal phases are called $\mathrm{P}, \mathrm{S}$, and $\mathrm{L}$ phases.

Plate. One of the mechanically independent lithospheric segments comprising the outermost layers of the Earth.

Right-lateral movement. The contrary of left-lateral movement. See Left-lateral movement.

Sand mounds. The deposits resulting from turbid upward flow of water and some sand to the ground surface from increased ground-water pressures when saturated cohesionless materials are liquefied by earthquake ground motions.

Sedimentation tank. A large reinforced concrete tank designed to house large amounts of water.

Seismogram. A record of ground motion caused by an earthquake.

Seismograph. A system for amplifying and recording the signals from a seismometer.

Seismometer. A device that detects vibrations of the Earth, and whose physical constants are known for calibration to allow calculation of the actual ground motion from the seismograph.

Seismoscope. An instrument that inscribes on a glass plate a permanent record of an earthquake. This instrument is an unconstrained pendulum that records strong ground motions.

Seismoscope plate. A record of ground motion caused by an earthquake.

Station code. Abbreviation of seismological stations: (1) of the WWNSS, (2) of stations in Guatemala prior to the February 4 earthquake, and (3) of field portable seismograph stations in Guatemala.
1. WWNSS stations mentioned in this report:

ALQ, Albuquerque, New Mexico

BRK, Berkeley, California

COL, College, Alaska

DUG, Dugway, Utah

GEO, Georgetown University, Washington, D.C.

GIE, Galapagos Island

GOL, Golden, Colorado

GUA, Guam

KIP, Kipapa, Hawaii

LON, Longmarie, Washington

PAS, Pasadena, California

PAL, Palisades, New York

PTO, Pôrto, Portugal

PRE, Pretoria, South Africa

SJG, San Juan, Puerto Rico

WES, Weston, Massachusetts

2. Stations in Guatemala:

ARC, Quiriguá, Department of Izabal

BVA, Buena Vista, Department of Guatemala

CHI, Chimachoy, Department of Sacatepéquez

FGO, Volcán de Fuego, Department of Escuintla

MMA, Magdalena Milpas Altas, Department of

Sacatepéquez

REC, Recreo, Department of Guatemala

TER, Terranova, Department of Escuintla

3. Field stations in Guatemala:

ARC, Quiriguá, Department of Izabal

CCO, Chichicastenango, Department of Quiché

CHM, Chimaltenango, Department of Chimaltenango

CML, Chiquimula, Department of Chiquimula

ELC, El Chol, Department of Baja Verapaz

FFF, La Piña, Department of Izabal

GCG, Guatemala City, Department of Guatemala

JAP, Jalapa, Department of Jalapa

JOY, Joyabaj, Department of Quiché

PAL, Palencia, Department of Guatemala

PTO, Puerto Barrios, Department of Izabal RIO, La Esmeralda, Department of Izabal

SAN, Sanarate, Department of El Progreso

SJE, San Jeronimo, Department of Baja Verapaz

TEC, Tecpan, Department of Chimaltenango

TEL, Teleman, Department of Alta Verapaz

VIT, Vitalis, Department of Izabal

Stereographic projection. A coordinate system or network of meridians and parallels, projected from a sphere at suitable intervals, used to plot points whose coordinates are known and to study orientation and distribution of planes and points.

Strike. Angle between true north and the trace or projection of a geologic surface or lineation on the horizontal plane.

Strike-slip fault. Fault in which movement is principally horizontal.

Strong motion. Ground motion of sufficient amplitude to be of engineering interest in the evaluation of damage due to earthquakes. This type of motion is usually recorded on seismoscopes and accelerographs. 
Surface-wave magnitude $\left(M_{s}\right)$. A measure obtained from the amplitude and period of surface waves at teleseismic distances.

Teleseismic. Refers to distances in the far field.

Thrust fault. A steeply or slightly inclined fault in which the block above the fault has moved upward or over the block below the fault.
Trench. Elongated bathymetric depression of the sea floor. Thought to be areas where oceanic crust is subducted into the upper mantle.

Universidad. University.

Wavelet. A short time series used in the deconvolution of a longer time series. It refers also to a time pulse.

Zone. Suburbs or districts in Guatemala City.

\title{
SYMBOLS AND ABBREVIATIONS
}

\author{
[See the Glossary also]
}

$A$-.-. area of dislocation. ${ }^{\circ} \mathrm{C}$ $\mathrm{cm}$ - _. $\mathrm{cm} / \mathrm{rad}$............. centimetres per radian. cm-s _._. $\mathrm{cm} / \mathrm{yr}$-........... $\bar{D}$.

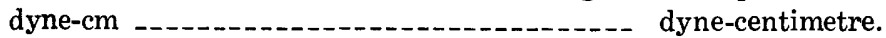
dyne $\mathrm{cm}^{-2}$ $\Delta$ $\Delta \sigma$ $E$. energy. See Glossary. Es _-_-_-_._- seismic energy. G2, G3, G4 _........................... Gaves. See Glossary. $g$-..- acceleration due to gravity $\left(980 \mathrm{~cm}-\mathrm{s}^{-2}\right)$. $H$ $\mathrm{Hz}$. $h$ $I_{\mathrm{mm}}$ ICAITI _..-.-.- Instituto Centroamericano de Investigacion y Técnologia Industrial.

$\mathrm{kg}$ kilogram. $\mathrm{km}$ $\mathrm{km}^{2}$-_$\mathrm{km}^{3}$. $\mathrm{km} / \mathrm{s}$. $L$ _._. $m$ - M - $\mathrm{m}_{\mathrm{b}}$ - . $\mathrm{M}_{\mathrm{L}}$
$M_{\mathrm{o}}$ seismic moment. $M_{s}$ min _. $\mathrm{mm} / \mathrm{min}$ ms - $\mathrm{ms} / \mathrm{day}$. . m.y. _$\mu$. NEIS -......... National Earthquake Information Service. $Q$ $r$. RMS _._. ROCAP - -.-- Regional Office for Central America Programs s S -

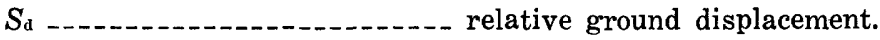
SQ calculating hypocenters.

o - - . $T_{1}$ $T_{2}$ $\theta$. $\bar{u}$. USAID _._....- U.S. Agency for International Development. UTC _...... Universal Coordinated Time. WWV . ....... Call letters for National Bureau of Standards time and frequency radio broadcast station, Fort Collins, Colorado.

WWNSS -- Worldwide Network of Standard Seismographs. $w$. $\dot{x}$ 



\title{
THE GUATEMALAN EARTHQUAKE OF FEBRUARY 4, 1976, A PRELIMINARY REPORT
}

\author{
A. F. EsPinosa, Editor
}

\section{ABSTRACT}

The Guatemalan earthquake of February 4, 1976, with a surface-wave magnitude of 7.5, was generated by left-lateral slippage on the Motagua fault and was felt over an area of at least $100,000 \mathrm{~km}^{2}$. This earthquake claimed more than 22,700 lives and injured more than 76,000 people. The preliminary estimate of losses is about $\$ 1,100,000,000$.

Ground breakage was observed and mapped for a distance of nearly $240 \mathrm{~km}$ along a segment of the fault. It is the longest surface rupture to have occurred in America since 1906. The inferred total length of faulting is nearly $300 \mathrm{~km}$, postulated on the basis of small aftershocks and high damage concentration west of Guatemala City. Maximum horizontal slippage as measured on the fault, about $25 \mathrm{~km}$ north of Guatemala City, was $325 \mathrm{~cm}$. The average horizontal displacement is approximately $100 \mathrm{~cm}$. Slippage also occurred on a number of secondary faults and caused damage to houses and other structures in the vicinity of Guatemala City.

The February 4 earthquake caused extensive landsliding along the highway that leads from Guatemala City to the Pacific and Atlantic Oceans. Landslides also blocked many railroads and destroyed many communication routes in the highlands of Guatemala. A large landslide near Tecpan covered two small villages and dammed a river. Additional landslides were triggered by aftershock activity.

Guatemala contains three major earthquake-generating zones. The first zone, which has the highest level of seismicity, is the Benioff zone that dips northeastward beneath Guatemala and is due to the Cocos plate being thrust beneath the Caribbean plate. The second lies at shallow depths along the chain of active volcanoes; the third is the fault system that bisects Guatemala from east to west. It is in this third zone that the February 4 earthquake occurred.

The preliminary fault plane solution is consistent with almost pure sinistral slip on a nearly vertical fault striking about $\mathrm{N}$. $65^{\circ} \mathrm{E}$. This solution agrees with the geologically mapped fault trace. The seismic moment was determined to be $2.6 \times 10^{27}$ dyne-cm from the amplitude of mantle Love waves (G-waves). A fault depth of $29 \mathrm{~km}$ was calculated from the seismic moment and the field observations of fault length and fault displacement. The earthquake was a low-stress-drop event, $3 \leq \Delta_{\sigma} \leq 18$ bars. The energy release was $1.1 \times 10^{23}$ ergs.

Thousands of aftershocks followed the main earthquake. Epicenters for 78 small aftershocks determined from locally recorded data delineate the Motagua fault and several secondary faults. A number of epicenters in the eastern part of Guatemala follow the general trend of the inferred extension of the Motagua fault. A large number of events that occurred south of the Motagua fault and west of long $90.3^{\circ} \mathrm{W}$. at depths of less than $14 \mathrm{~km}$ are associated with secondary faults, such as the north-south faults that bound the Guatemala City graben.

The maximum Modified Mercalli intensity was IX in the Mixco area, in some sections of Guatemala City, and in Gualán. The Modified Mercalli intensity reached VI over an area of $33,000 \mathrm{~km}^{2}$. The concentration of high intensities observed near the western end of the Motagua fault suggests the influence of a westward-propagating fault rupture.

Communities and small towns that suffered 100 percent damage covered an area of $1,700 \mathrm{~km}^{2}$. At some localities, adobe structures near the causative fault (within $10 \mathrm{~km}$ ) were essentially undamaged; at greater distances from the fault in the highlands, there was widespread collapse of adobe buildings. Modern earthquake-resistive structures in Guatemala City were damaged, including several hospitals. Several water tanks and corrugated-steel grain silos and numerous heavy parapets collapsed.

The information compiled in this study will be useful in assessing and delineating earthquake hazards in Guatemala to reduce the potential for loss of life and property in future earthquakes. The information in this study is also important in evaluating the effects to be expected from large strikeslip earthquakes elsewhere, such as those that occur in coastal California. A more detailed study of the distribution of intensities in Guatemala City could provide the basis for delineating variations in the hazards due to ground shaking and ground failure throughout the city and could assist in developing land-use policies.

\section{INTRODUCTION}

The Republic of Guatemala in Central America suffered extensive loss of life and severe damage to its economy from the February 4, 1976, earthquake. A request by the Guatemalan government to the Organization of American States prompted the U.S. Geological Survey to send a team of scientists and engineers to Guatemala to investigate the cause of the earthquake, the geologic, seismologic, and engineering effects, and the hazards resulting from the earthquake. U.S. Geological Survey Open-File Report 76-295, which was released in March 1976, provided a brief interim summary of the activities 


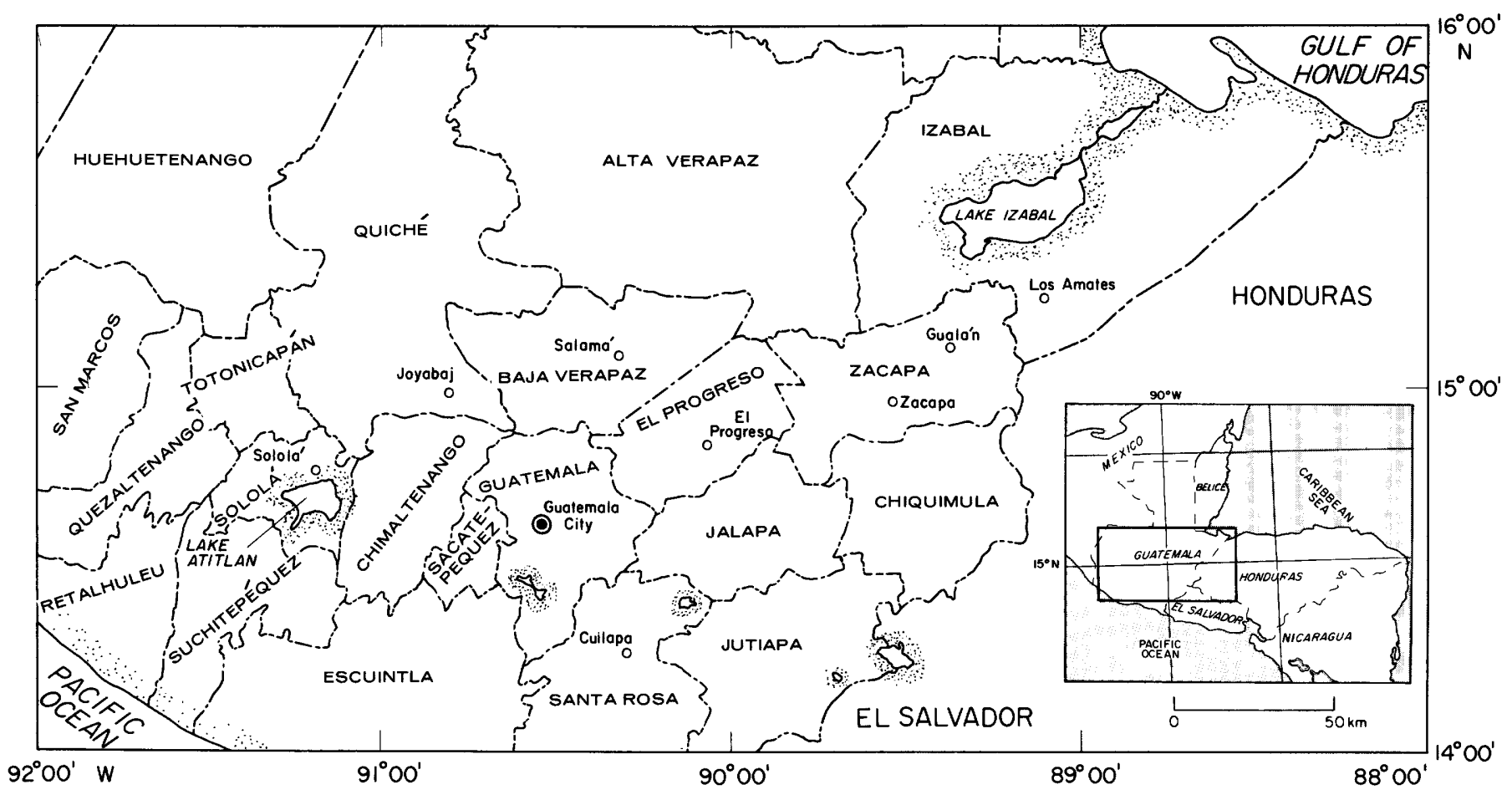

Figure 1.-Guatemala and its Departments (States), including its general location in Central America. Base map modified from Guatemala, Instituto Geográfico Nacional, 1974, 1:500,000.

of the earthquake investigation team. The open-file report and this publication represent the immediate response by our agency to the request of the Guatemalan government.

Guatemala has a long history of damaging earthquakes. Historic chronicles date earthquake occurrences in Guatemala from the period of the Spanish conquest. The chronicles indicate that the cities of Antiqua and Guatemala City have been badly damaged by earthquakes more than 15 times since the early 16th century. The most damaging earthquakes to have occurred before the February 4 event were on December 25, 1917, and on January 3, 1918. These earthquakes and their aftershocks claimed numerous lives and partially destroyed Guatemala City.

The February 4 earthquake caused extensive damage, as the following statistics from a few of the cities and Departments (States) show: 88,404 houses were destroyed and 434,934 people left homeless in the Department of Guatemala, about onehalf that number in the Department of Chimaltenango (fig. 1), and all houses were destroyed in the towns of San Pedro Sacatepéquez, El Jicaro, Sumpango, Tecpan, and Gualán.

From the above, it is obvious that the principal hazard to life from earthquakes in the Republic of
Guatemala is the collapse of manmade structures because of ground shaking. There are, in addition, other serious earthquake hazards, especially landslides in the highlands and surface breakage along active faults. Landslides can interrupt lifelines, in particular, roads, railroads, and communication networks, and they can dam streams and cause lakes that are subject to sudden release upon failure of the dam.

There is much to learn from this earthquake that is directly relevant to the problem of reducing earthquake hazards in the United States. The fault that produced the earthquake is the boundary between two crustal plates and is tectonically similar to the San Andreas fault in California and to the Fairweather fault in southeastern Alaska. Many of the modern buildings in Guatemala City are similar to structures in the United States and in particular to those in cities in coastal Califormia.

The different papers of this report present (1) the tectonic setting and the seismicity of the region; (2) the local seismic activity before the February 4 earthquake; (3) the main event and principal aftershocks as recorded at teleseismic distances; (4) the source parameters of the main event and possible future earthquakes on the fault that slipped on February 4; (5) estimation of strong ground 
motion due to the main event; (6) aftershocks from local data and their relation to primary and secondary faulting; (7) the geologic effects, including primary and secondary faults, landslides, and relation of faulting to damage; (8) the intensity of shaking and its distribution, casualties and damage, groundmotion parameters at intermediate distances, and source parameters from field observations; (9) damage and engineering implications and earthquake-resistant design code; and (10) design, construction practice, and general observations on damage to high-rise structures.

The results from this collective investigation will aid in the reduction of earthquake hazards in Guatemala and in the United States, but the material presented in this report should be considered as preliminary. Some of the details may change, and the conclusions may be modified upon further scrutiny of existing data and upon analysis of new data gathered in later geologic field studies.

\section{ACKNOWLEDGMENTS}

We gratefully acknowledge: Colonel J. Guillermo Echeverria Vielman, Coordinator of the Comite Nacional de Emergencia; Mr. Jose Asturias, Scientific Coordinator of the Comite Nacional de Emergencia; Dr. Eduardo Gonzalez Reyez, Executive Secretary for Education, Science, and Culture of the Organization of American States; Dr. Gabriel Dengo, Director of the Instituto Centroamericano de Investigacion y Tecnologia Industrial; and Ing. F. Hernandez Cruz, Director General, Instituto Geográfico Nacional, for their full support in our investigation. Mr. M. Freundel, Assistant Director USAID/ ROCAP, provided ground transportation and an excellent chauffeur. We wish to acknowledge the support given to us, in the questionnaire canvassing of Guatemala City, by Ing. M. A. Castillo Barajas, Director, and Ing. H. E. Molina, Assistant Director, of the Civil Engineering Department of the Universidad de San Carlos. Also, we are grateful to the university students who participated in this effort and to Dr. S. B. Bonis of the Instituto Geográfico Nacional, who also obtained a great number of intensity questionnaires for our program. We wish to thank the Camara de Construccion and the Instituto Geográfico Nacional for providing us with temporary office space. We also would like to thank the helicopter officers and staff of La Fuerza Aerea Guatemalteca for their efficient and enthusiastic support of our canvassing fieldwork.

We gratefully acknowledge the support given to us by members of the Guatemala Air Club and particularly Messrs. Rudy Weissenberg C., Antonio Delgado Wyld, and François Berger, who generously made their personal aircraft available for our reconnaissance studies of the Motagua fault. Mr. David Schwartz of the Woodward-Lundgren Company participated with us in some of the fieldwork along the Motagua fault and freely shared his personal knowledge of the geology in part of this area. We wish to thank Messrs. D. F. Miller and A. Sunderman, engineers with ROCAP, for their support while we were in Guatemala. Also, Dr. O. Salazar of the Instituto Geográfico Nacional gave full support to our efforts in Guatemala.

We wish to thank Mr. A. Gregg of the InterAmerican Geodetic Survey; the U.S. Military Group; Mr. C. Urrutia, Director, and Mr. E. Sanchéz, technician, of the Observatorio Nacional for their support to our seismic network task. The helicopter support for this program was provided by the U.S. Army, 114th Aviation Company, from Panama. Mr. J. Irriarte, a geologist with the Instituto Nacional de Electrificacion, gave us field support and participated with us in the deployment of our seismic equipment. Our most sincere thanks are also due to the Guatemalans, both private citizens and public officials, who helped by relating their personal experiences about the earthquake, to those who provided support to our mission, and to those who provided information to our efforts. Without their support, this investigation would not have been as fruitful as it has been. 
THE GUATEMALAN EARTHQUAKE OF FEBRUARY 4, 1976, A PRELIMINARY REPORT

\title{
TECTONIC SETTING AND SEISMICITY
}

\author{
By William Spence and Waverly Person
}

\section{INTRODUCTION}

The February 4, 1976, main event occurred within the Motagua fault zone, the active boundary between the North American and Caribbean plates. The tectonic setting for the region of the Caribbean plate, with seismicity for the years $1962-69$, is shown in figure 2.

The absolute motion of the Caribbean plate has been shown to be nearly fixed, assuming stationarity of the hot-spot reference frame (Jordan, 1975). Thus, the average relative plate motions-CocosCaribbean $\left(7.47 \mathrm{~cm} / \mathrm{yr}\right.$ at $25.3^{\circ}$ azimuth), North American-Caribbean $\left(2.08 \mathrm{~cm} / \mathrm{yr}\right.$ at $252.4^{\circ}$ azimuth), and Cocos-North American $(9.01 \mathrm{~cm} / \mathrm{yr}$ at $35.0^{\circ}$ azimuth) - directly cause the seismicity of the region of Guatemala. These plate motions were calculated at lat $15^{\circ} \mathrm{N}$., long $90^{\circ} \mathrm{W}$. from relations given by Minster and others (1974). The rupture of the February 4 earthquake progressed into the zone of the triple junction between the Cocos, Caribbean, and North American plates and thus assumes a particular significance.

\section{SEISMICITY}

The seismicity of the zone from lat $13^{\circ}-18^{\circ} \mathrm{N}$., long $87^{\circ}-95^{\circ} \mathrm{W}$. for the period $1902-75$ is shown in figure $3 A$. The main event and its nine largest aftershocks, through March 7, 1976, are shown by $x$ 's (Person and others, this report). The Motagua fault zone is notable for its lack of major earthquakes from 1902 (or earlier) until the February 1976 main event and is a clear example of a seismic gap on the Caribbean-North American plate boundary. The one large earthquake epicenter shown near the western end of the mapped Motagua fault $\left(M_{S}=7.5,1921\right)$ is assigned a focal depth of 120 $\mathrm{km}$ (Gutenberg and Richter, 1954) and thus is associated with the subducting Cocos plate rather than with the Motagua fault. The eastward extension of the Motagua fault, the Swan fracture zone, has been seismically active during this period. It is characterized by shallow, left-lateral, strike-slip faulting (Molnar and Sykes, 1969). The maximum seismicity in this figure occurs with the zone from lat $14^{\circ}-15^{\circ} \mathrm{N}$., long $91^{\circ}-94^{\circ} \mathrm{W}$. and suggests that a complex tectonic regime is associated with the Caribbean-Cocos-North American triple junction.

Five cross sections through this Middle America seismic zone, for the period 1962-72, are shown in figure $3 B$ (A. C. Tarr, written commun., 1976). These show that the diffuse seismicity in figure $3 A$ is largely attributable to the underthrusting of the Central American continental mass by the Cocos plate. Of the 1,331 earthquakes that occurred during the period $1902-75$, shown in the map portion of figure $3 A$, the 17 events with $\mathrm{M}_{\mathrm{s}} \geqslant 7.0$ apparently are associated with the subduction of the Cocos plate. The seismicity of these cross sections is more diffuse than that of seismic cross sections that are based on high-quality local data for island ares (for example, Engdahl, 1971, 1973; Mitronovas and others, 1969). An increased resolution of the dip of the Cocos plate beneath Nicaragua has been obtained by a relocation of earthquakes in that area (Dewey and Algermissen, 1974). An improved picture of Guatemalan regional seismicity as a series of cross sections could provide insight into the nature of the associated triple junction.

A major seismic gap has been noted at the western coast of Central America between long $88^{\circ}$ and $91^{\circ} \mathrm{W}$. (Kelleher and others, 1973). Now that the Motagua fault-lock zone has ruptured, the possibility that additional major earthquakes could occur deserves special study. South of the Motagua fault, an eastward relaxation of the Caribbean plate coupled with an accelerated local subduction of the Cocos plate could result in underthrust-type earthquakes that would fill this seismic gap. North of the Motagua fault, an accelerated westward motion of the North American plate could override the Cocos plate and lead to normal faulting off the southwestern coast of Mexico. 


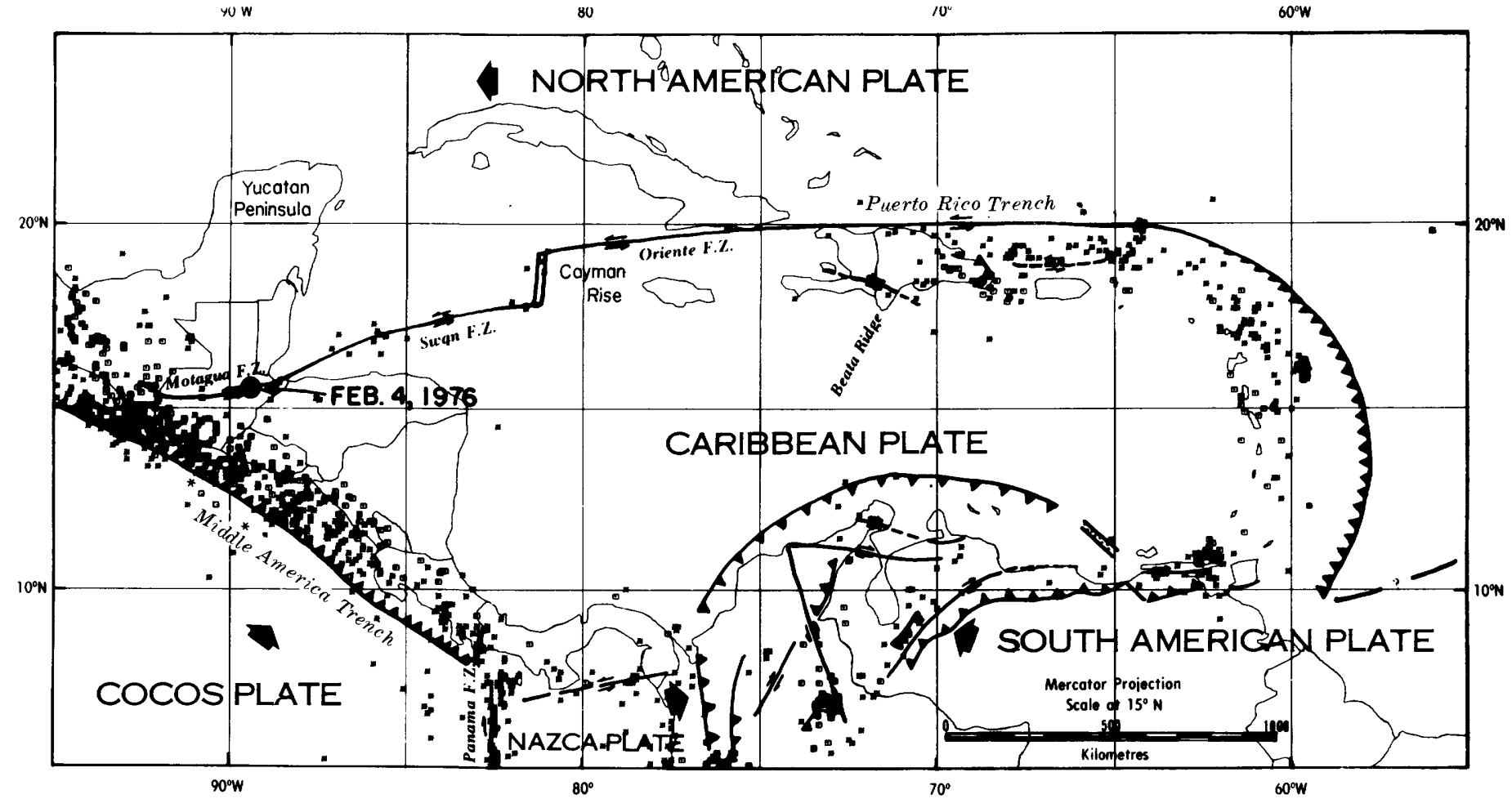

Figure 2.-Tectonic setting of the Caribbean plate. The Motagua fault zone, Swan fracture zone, Oriente fracture zone, and Puerto Rico Trench are elements of a major transform fault system on which the North American plate moves westward, at $2.1 \mathrm{~cm} / \mathrm{yr}$, relative to the nearly stationary Caribbean plate. Large arrows indicate direction of plate movement. The location of the February 4 Guatemalan earthquake is shown by the large dot. Small squares are previous earthquake locations. Serrated line indicates subduction. Modified from Jordan (1975) by Tarr and King (1976).

\section{HISTORICAL SEISMICITY}

Historical accounts of damaging earthquakes in Guatemala are numerous and date from the time of the Spanish conquest. A particularly destructive earthquake occurred in 1541 near Ciudad Vieja, the primary early Spanish settlement in Guatemala, and caused the deaths of approximately 150 Spaniards and at least 600 Indians and Negroes. The Spanish settlement subsequently was moved to nearby Antigua, and this city became the original capital of Guatemala. Antigua was extensively damaged by earthquakes 11 times between 1565 and 1773. Accounts say that Antigua was destroyed in $1586,1717,1773$, and 1874. Following the 1773 earthquake, Guatemala's capital was moved to Guatemala City.

Before 1976, Guatemala City had experienced damaging earthquakes in 1917-18, 1863, and 1862. The December 25, 1917, earthquake destroyed or seriously damaged about 40 percent of the houses in Guatemala City. This earthquake was followed by large earthquakes on December 29, 1917, January 3,1918 , and January 24,1918 . The most damaging earthquake of the 1917-18 series was that on January $3,1918$.
A chronological historical record of important Guatemalan earthquakes, from 1526 to the time of the February 1976 main event, for noninstrumental and instrumental data is given on p. 87. Included are earthquakes occurring in or offshore from Guatemala that caused damage or are known to have had a magnitude greater than or equal to 6.0. The source of descriptive information for each earthquake is indicated in parentheses. At this writing, primary sources have not been checked for all earthquakes, and thus the information in the chronological listing may contain occasional omissions or errors.

In figure 4, the earthquakes in the chronological historical listing that have instrumentally determined epicenters are plotted as triangles, and the larger or better described earlier earthquakes are plotted at their maximum damage zone as squares. A notable recent earthquake series occurred near Mazatenango. The October 23, 1950, earthquake $\left(\mathrm{M}_{\mathrm{s}}=7.1\right)$ was followed, within 2 weeks, by six aftershocks of $M_{S} \supseteq 6.0$. The pattern of historical seismicity in Guatemala is similar to that based on reliable epicenter estimates, such as shown in figure $3 A$. Notably, there is a general lack of major his- 


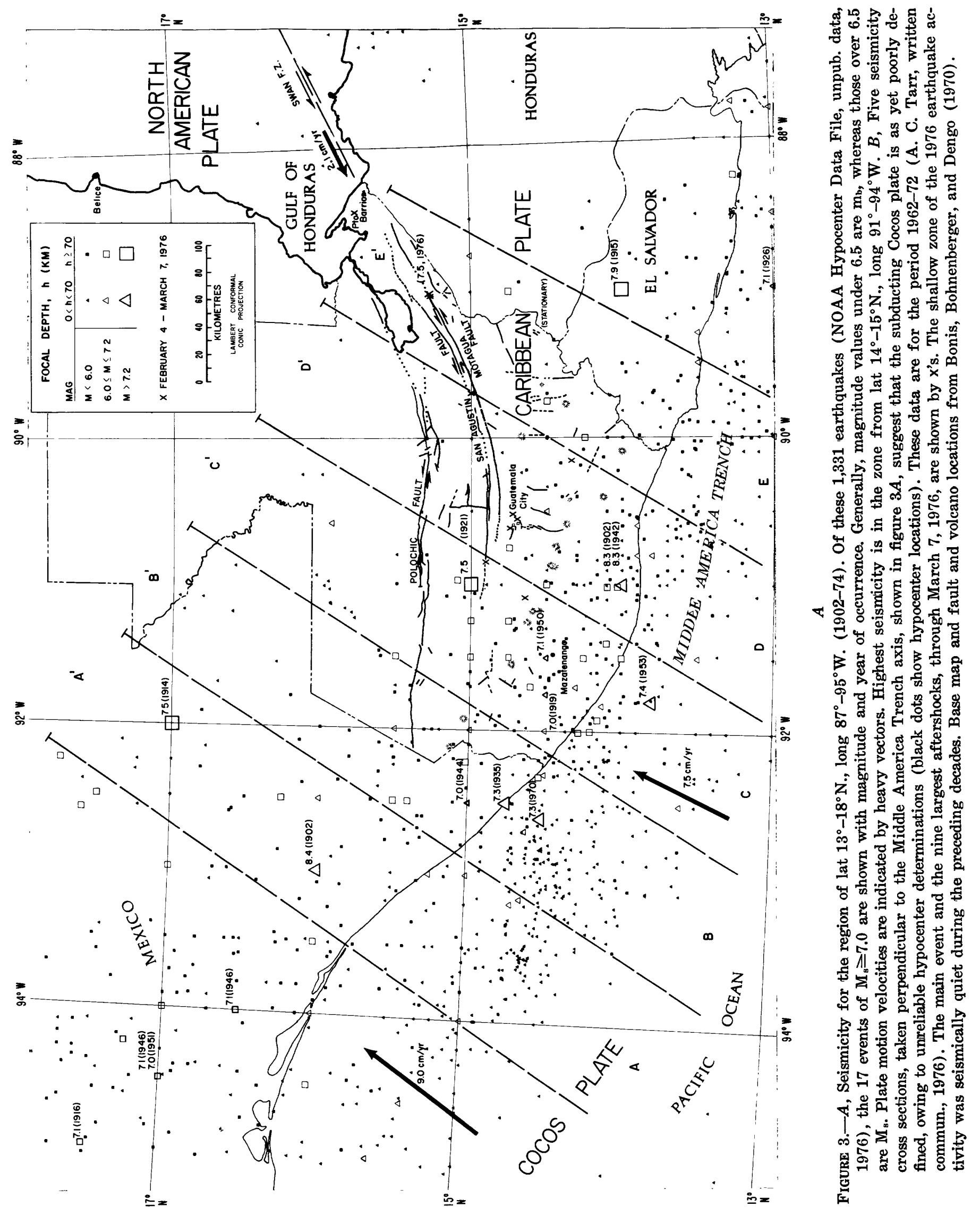



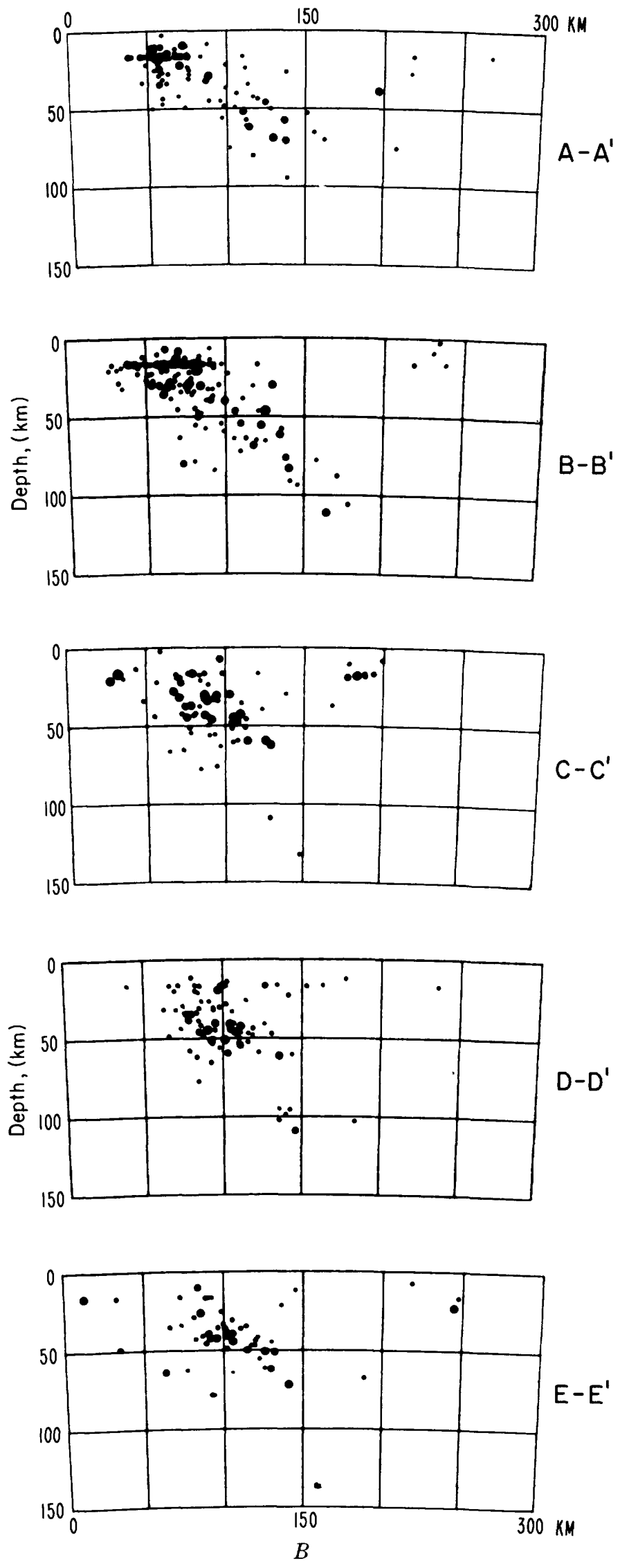

Figure 3.-Continued. torical earthquakes that can definitely be associated with the Motagua fault.

Because of scattered population centers and poor communication, the historical accounts of earthquakes provide only approximate estimates of an earthquake's epicenter. As an illustration, there have been two $M_{s}=8.3$ earthquakes with epicenters at lat $14.0^{\circ} \mathrm{N}$., long $91.0^{\circ} \mathrm{W}$. in 1902 and 1942. The first of these is reported to have destroyed Quezaltenango and to have activated Santa Maria Volcano (Vassaux, 1969). No data are available, in conventional sources, on the cities of Antigua, Comalapa, or Mazatenango, which were nearer to the epicenter. The 1942 earthquake is described as "strongly felt throughout the central region of Guatemala" (Seismological Society of America Bulletin, 1942). The problem for earlier earthquakes sometimes is more severe.

However, based on both historical and modern records of Guatemalan seismicity, we conclude that large earthquakes on the Motagua fault occur only rarely. Although the historical record is incomplete and imprecise, we feel that, before the February 4 main event, the most recent large earthquakes that may have occurred on the Motagua fault are those of April 1765 and 1773. The 1765 earthquake destroyed many towns in the Department of Chiquimula and is placed by us on the Motagua fault at about long $89.5^{\circ} \mathrm{W}$. The major earthquake of July 29, 1773, was preceded by numerous foreshocks, unlike the February 4 event. However, Montessus de Ballore's (1888) source reports that, although the 1773 event destroyed Antigua, it was felt even more strongly to the north, in Chimaltenango and Quezaltenango. Thus, this major earthquake may have occurred on the western Motagua fault. The moderate earthquake of January 1929 caused considerable damage at Puerto Barrios. It is reasonable to associate this earthquake with the western portion of the Swan fracture zone or possibly with the eastern extremity of the Motagua fault. A moderate earthquake occurred somewhat west of the 1929 event on August 10, 1945. The U.S. Coast and Geodetic Survey located it at lat $15.4^{\circ}$ N., long $88.8^{\circ} \mathrm{W}$. (not shown in fig. 4), and this earthquake could reasonably be associated with the Motagua fault. This event caused significant damage at Quiriguá and was felt in the Departments of Chiquimula, Zacapa, and part of Izabal (Seismological Society of America Bulletin, 1945).

We conclude that the return period for major earthquakes on the central and western Motagua fault is at least 200 years. The average relative 


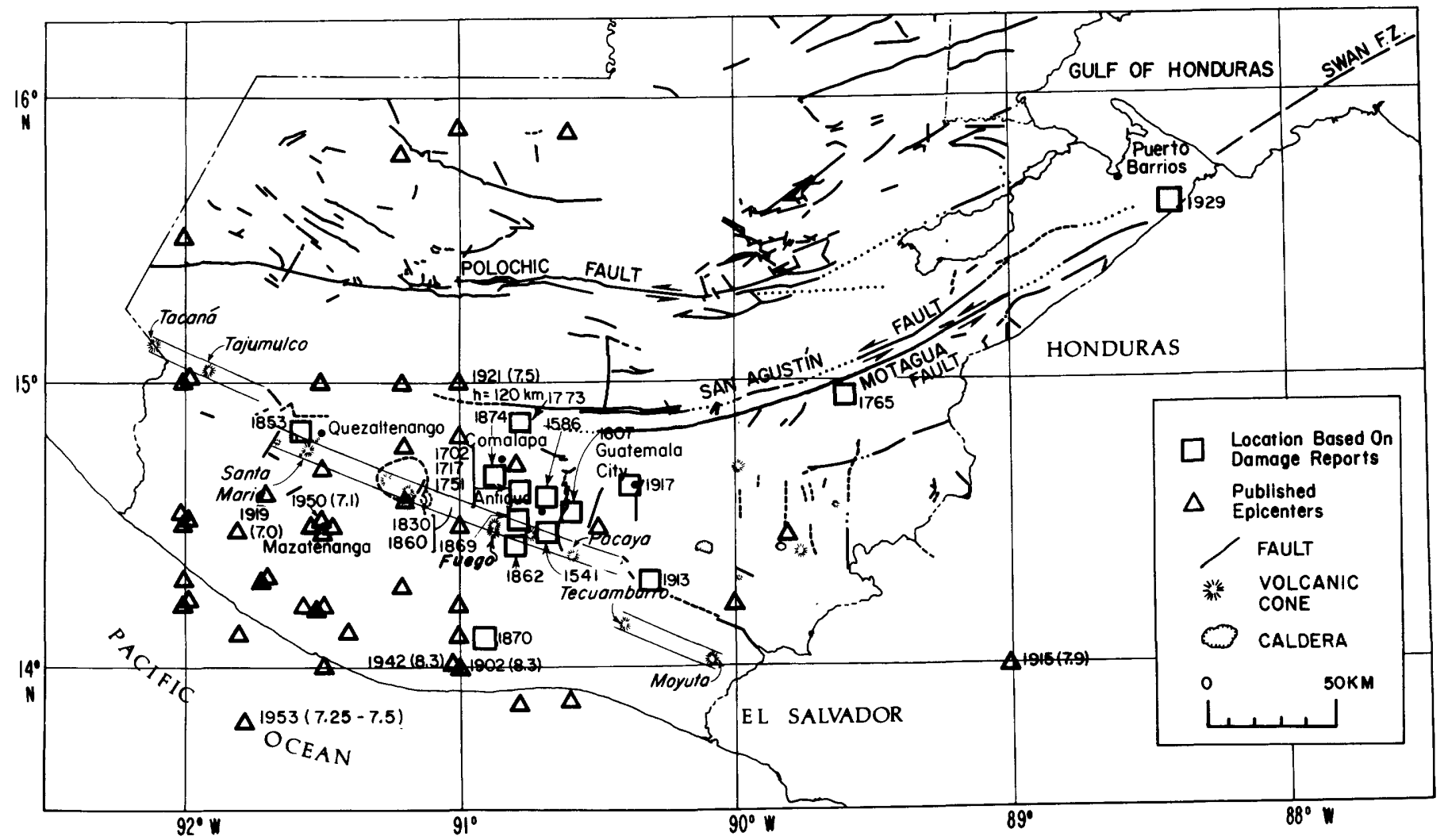

Figure 4.-Historical seismicity of Guatemala. Epicenters based on P-wave arrival time data are shown by triangles. The closed dashed line is an inferred ring fault. The larger or better described earlier events (a chronological historical listing is on p. 88) are plotted as squares at the site of maximum reported intensity. The zone near Antigua apparently has particularly high seismicity. Except for the 1765 event, there is a marked absence of historical seismicity associated with the Motagua fault. Distribution of faults and volcanoes modified from Bonis, Bohnenberger, and Dengo. (1970). Additional geological information is available from Dengo and Bohnenberger (1969) and Dengo (1969). Segmentation and off set of the Guatemalan volcanic linears (light parallel lines) into eastern, central, and western limbs are described by Stoiber and Carr (1973).

plate velocity between the North American and Caribbean plates of $2.1 \mathrm{~cm} / \mathrm{yr}$ then implies that the maximum displacement of a major Motagua fault earthquake should be of the order of $4 \mathrm{~m}$. The February 4 main event had a measured maximum displacement of about $1.5 \mathrm{~m}$ (Plafker and others, this report). This difference can be explained by the occurrence of creep and small-to-moderate earthquakes on the Motagua fault or by sudden differential displacement at the time of the February 4 main event along buried parallel strands within the Motagua fault system.

\section{TECTONIC HISTORY OF THE CARIBBEAN-NORTH AMERICAN PLATE BOUNDARY}

Until recently, the tectonic history of the Caribbean region has been one of the more perplexing elements in plate-tectonics reconstructions. The Caribbean plate has existed for approximately 50 million years (Malfait and Dinkelman, 1972; Pinet, 1972).

The Caribbean-North American plate boundary between Hispaniola and Guatemala consists of two fracture zones, the Oriente fracture zone to the east and the Swan fracture zone to the west (fig. 2). The Cayman Trough and Ridge are subparallel to these fracture zones. An offset in seismicity corresponds to the offset of these two fracture zones (Bowin, 1968). Holcombe and others (1973) have used morphological arguments to demonstrate that this offset corresponds to an active center of eastwest spreading, the Cayman Rise.

Centered at the Cayman Rise, a series of symmetrically spaced, north-south-trending ridges has been mapped out to $150 \mathrm{~km}$ east and west from the Cayman Rise (Holcombe and others, 1973). This evidence for east-west spreading conclusively supports the occurrence of extensive left-lateral dis- 
placement at the Caribbean-North American plate boundary. Pinet (1972) argues that this left-lateral displacement is longer than $1,000 \mathrm{~km}$, based on correlation of salt-piercement structures on opposite sides of the Motagua fault, in northern Honduras and in Guatemala. Hess and Maxwell (1953) estimated this left-lateral offset to be about $1,100 \mathrm{~km}$.

The Caribbean plate is inferred to be approximately stationary in an absolute plate-velocity reference frame (Jordan, 1975). This conclusion is based on the hot-spot hypothesis as advanced by Wilson (1963) and Morgan (1971) and supported by Minster and others (1974). Thus, the North American plate is moving westward with respect to the middle-American portion of the Caribbean plate and is overriding the Cocos plate. The left-lateral offset associated with the Caribbean-North American plate boundary should persist through Guatemala; the Motagua fault is the continental extension of this active plate boundary.

This model has been dramatically confirmed by the occurrence of the 1976 Guatemalan earthquake. Heretofore the lack of field evidence for left-lateral displacement on the Motagua fault (McBirney, 1963; McBirney and Bass, 1969; Falquist and Davies, 1971; Kesler, 1971) and the sphenochasm hypothesis for the opening of the Gulf of Honduras (Carey, 1958; Freeland and Dietz, 1971; Uchupi, 1973) had left the character of the northwestern Caribbean in some doubt.

One model for the evolution of the Caribbean plate is illustrated in figure 5 (Malfait and Dinkelman, 1972). This model begins with an eastward extension of the "East Pacific" plate into the present-day Caribbean zone and requires a progressive extension of subduction and island-arc volcanism from the position of southern Mexico towards the western side of the South American plate. This model includes a clockwise rotation of the Caribbean plate from the inferred north-northeast motion of the "East Pacific" plate to the present-day position as shown in figure 2.

Malfait and Dinkelman's model also includes large-scale left-lateral displacement at the Polochic or Motagua fault systems. A surprisingly well fitting reconstruction of pre-Late Cretaceous plate elements at this zone can be obtained by moving the North American plate eastward on the Polochic fault (for example, King, 1969) to a position where a match is obtained for the 500 -fathom isobaths of eastern Yucatan and eastern Honduras. The required displacement is $1,000-1,100 \mathrm{~km}$.

\section{THE GARIBBEAN-COCOS-NORTH AMERICAN PLATE TRIPLE JUNGTION}

Jordan (1975) has shown the southwestern Caribbean plate triple junction to be an exceedingly large zone of plate interaction. The northwestern Caribbean triple junction, which includes the Motagua fault system, is a smaller and probably less complex zone. We here attempt to set first-order bounds to the Caribbean-Cocos-North American triple junction zone. We use evidence of the occurrence of unusual tectonic activity, including very high levels of seismicity and volcanism, as indicative of the presence of this triple junction zone.

Although the eastern portion of the Motagua fault is approximately linear and parallel to the local direction of relative plate motion, this fault begins to curve, concave to the north, at about long $89.5^{\circ}$ W. This change in fault direction may be tied to the complex stress field associated with this triple junction. The extreme western wedge of the Caribbean plate, west of about long $89.5^{\circ} \mathrm{W}$. and between the mapped Motagua fault and the linear volcanic segments (shown in fig. 4), is characterized by north-south-striking faults and a diffuse zone of volcanism (Bonis and others, 1970).

Although the main-event rupture followed the curve of the Motagua fault, few (perhaps none) of the aftershocks and none of the extensive northtrending secondary faulting occurred to the north of the Motagua fault (Langer and others, this report; Plafker and others, this report). Plafker, Bonilla and Bonis (this report) found the occurrence of active secondary faulting (normal, down to the east) as far as $30 \mathrm{~km}$ from the main fault. This remarkable character of the aftershock distribution and secondary faulting is consistent both with: (1) the tendency of the Motagua fault to develop parallel to the relative motion of the North American and Caribbean plates and (2) an eastward relaxation of the Caribbean plate following the primary rupture at the Motagua fault.

Present-day seismicity, shown in figures 3 and 4 , is concentrated in the zone from lat $14^{\circ}-15^{\circ} \mathrm{N}$, long $91^{\circ}-94^{\circ} \mathrm{W}$., the preponderance of large earthquakes occurs at shallow and intermediate depths at the smaller zone from lat $14^{\circ}-15^{\circ} \mathrm{N}$., long $91^{\circ}-$ $92.5^{\circ} \mathrm{W}$. The linear extension of the eastern Motagua fault passes through the concentration of large shallow- and intermediate-depth earthquakes at lat $14^{\circ}-15^{\circ} \mathrm{N}$., long $91^{\circ}-92.5^{\circ} \mathrm{W}$.

In recent geologic time, the central Guatemalan volcanic lineament has been the most active volcanic segment in Central America (Stoiber and 

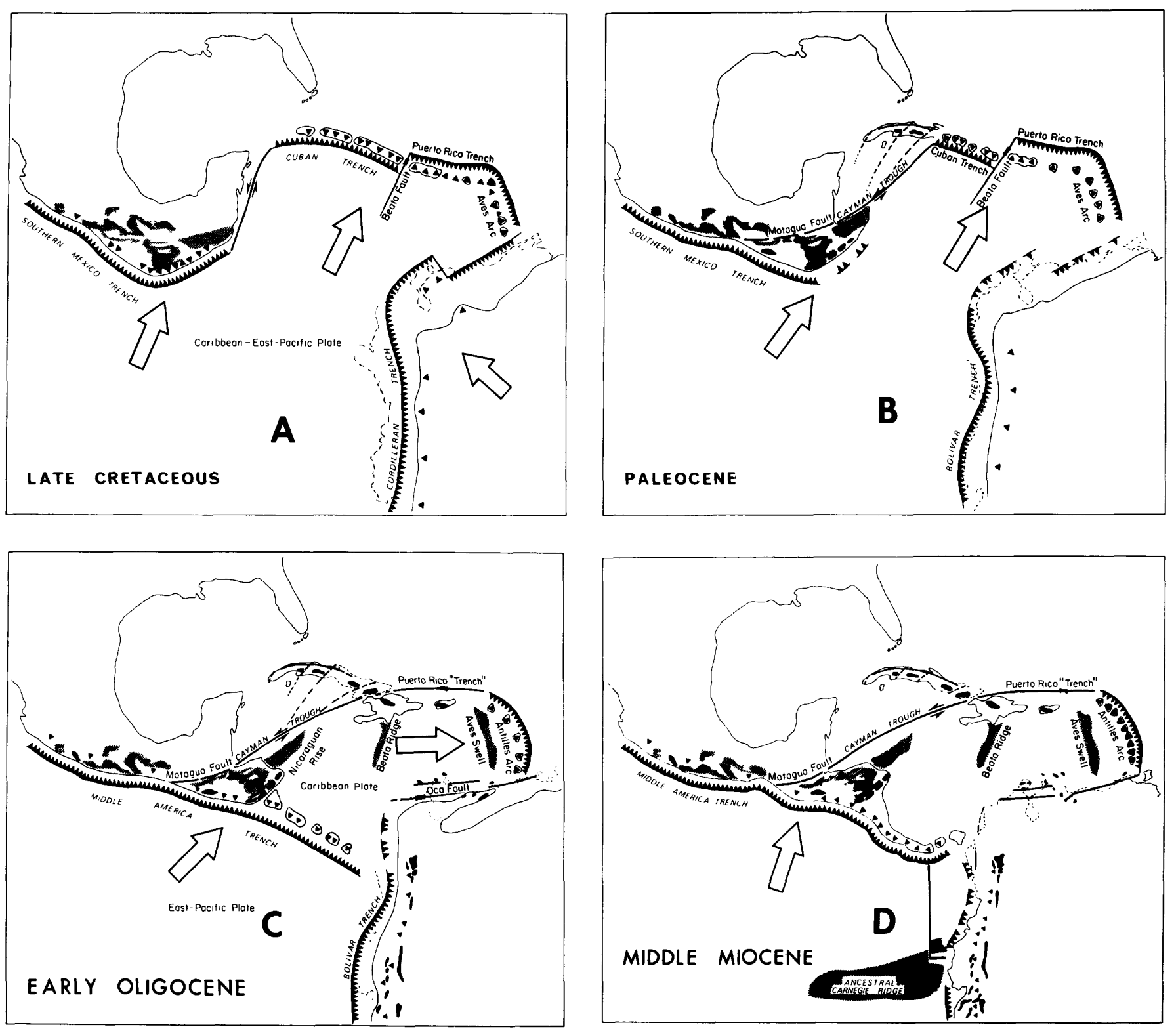

Figure 5.-Model for the evolution of the Caribbean plate. (Used by permission from Malfait and Dinkelman, 1972.) Arrows indicate motion relative to the North American plate. Solid triangles indicate volcanoes.

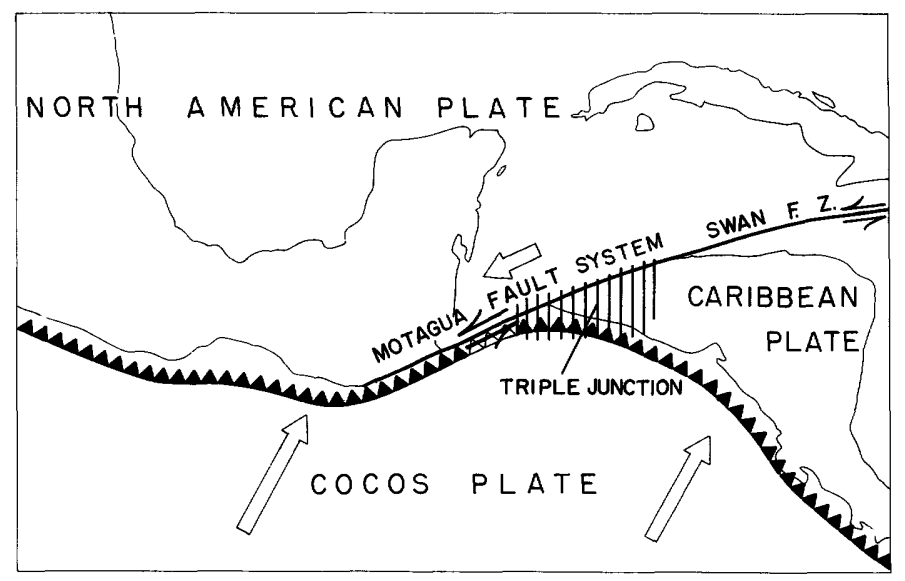

Figure 6.-Possible appearance of the Caribbean-Cocos-North American plate triple junction and nearby plate boundaries 50 m.y. from now, assuming that there will be no major changes in local plate motions. The tendency for this plate geometry to develop may explain the presentday east-west elongation of the Caribbean-Cocos-North American plate triple junction. Open arrows indicate motion relative to the Caribbean plate; serrated line indicates underthrusting or subduction. 
Carr, 1973). Fuego Volcano (lat $14.48^{\circ}$ N., long $90.88^{\circ}$ W.) is midway in the central Guatemalan volcanic segment and is located about $45 \mathrm{~km}$ westsouthwest of Guatemala City. Fuego is near the linear extension of the eastern Motagua fault and is the most active volcano in Central America. Fuego produced major eruptions totaling $0.5 \mathrm{~km}^{3}$ during October 1974 (Bonis, 1976).

Assuming that the long, tabular concentration of extremely high seismicity and volcanism in southern Guatemala, coupled with the curve of the Motagua fault, reflects the complex tectonics of a triple junction zone, we suggest approximate bounds to this zone of lat $14.0^{\circ}-15.0^{\circ} \mathrm{N}$., long $89.5^{\circ}-94.0^{\circ} \mathrm{W}$. This triple junction of two trenches and a transform fault should be viewed as a three-dimensional zone of accommodation between three lithospheric plates.
Because of the relative westward motion of the North American plate, there should be a definite tendency for the Motagua fault to evolve westward. This should ultimately result in a new east-westtrending boundary between the Cocos and North American plates. This boundary should be characterized by both subduction of the Cocos plate and left-lateral transcurrent motion of the North American plate. The eastern terminator of the CaribbeanCocos-North American triple junction will tend to remain spatially and geometrically stable. Such a present-day evolution from the Guatemalan triple junction zone may explain the extended east-west character inferred for this triple junction. Figure 6 is a schematic diagram showing the CaribbeanCocos-North American plate triple junction and nearby plate boundaries as they might appear $\mathbf{5 0}$ m.y. from now, assuming that no major changes in local plate motions occur. 


\title{
THE GUATEMALAN EARTHQUAKE OF FEBRUARY 4, 1976, A PRELIMINARY REPORT
}

\section{INSTRUMENTALLY RECORDED SEISMIC ACTIVITY PRIOR TO THE MAIN EVENT}

\author{
By David H. Harlow
}

\begin{abstract}
INTRODUCTION
Instrumental recording of earthquakes in Guatemala began in 1925 with the installation of a threecomponent Wiechert seismograph at the Observatorio Nacional in Guatemala City (Vassaux, 1969). No other permanent seismographs were operated in Guatemala until early 1973, when three radio-telemetered high-gain seismic stations were installed near Guatemala City and Pacaya and Fuego Volcanoes as part of a cooperative project between the U.S. Geological Survey and government agencies of Guatemala, El Salvador, and Nicaragua to monitor seismic activity and ground tilt at active volcanoes in Central America. This project is described in detail by Ward and others (1974). The cooperating

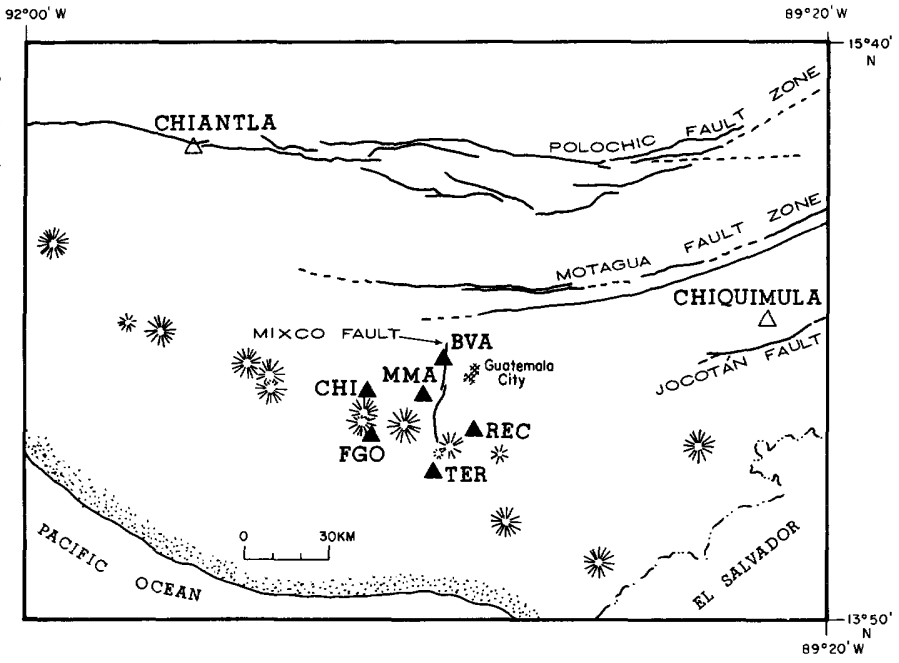
agency in Guatemala was originally the Instituto Geográfico Nacional and since early 1975 has been the Observatorio Nacional.

In March 1973, seismographs were temporarily installed at Chiantla and Chiquimula in cooperation with Dartmouth College, the Instituto Geográfico Nacional, and the U.S. Geological Survey. The purpose of these instruments was to monitor earthquake activity on an east-west system of faults that cuts across central Guatemala and consists mainly of the Polochic, Motagua, and Joctán faults (Quittmeyer, written commun., 1974).

Three additional radio-telemetered stations were added in February 1975, bringing the total to six. The purpose of this seismic network is to monitor earthquake activity associated with faults and active volcanoes.

The locations of the permanent and temporary seismic stations are plotted in figure 7 , and station data are listed in table 1 . Seismometers with a natural frequency of $1 \mathrm{~Hz}$ are employed at each station. The seismic signals from the permanent stations are relayed to the Observatorio Nacional and recorded on drum recorders at a paper speed of 60 $\mathrm{mm} / \mathrm{min}$. A description of the instrumentation and
Figure 7.-Seismic station locations. Temporary seismic stations operated during 1973 are shown by open triangles, and the existing telemetering stations are shown by solid triangles. Volcanic cones are also shown.

the response curve can be found in Ward and others (1974). For the Chiantla and Chiquimula stations, recording was done on site.

\section{SEISMICALLY ACTIVE AREAS IN GUATEMALA}

Molnar and Sykes (1969) studied the regional tectonics of the Caribbean and Central America by using earthquake hypocenters and focal mechanisms for earthquakes larger than magnitude 4.0 recorded by the WWNSS between 1954 and 1967 . The most prominent seismic feature is a zone of earthquakes that dips northeastward beneath Central America and appears to be the result of the convergent plate motion and underthrusting of the Cocos plate beneath the Caribbean plate. Hypocenters for earthquakes within this zone range from near-surface depths at the Middle America Trench to depths of approximately $100 \mathrm{~km}$ beneath the line of active volcanoes and then to maximum depths of about $250 \mathrm{~km}$ (fig. $3 B$ ). During this time inter- 
TABLE 1.-Coordinates and magnifications of seismograph stations

\begin{tabular}{|c|c|c|c|c|}
\hline Stations ${ }^{1}$ & $\begin{array}{c}\text { Latitude } \\
\left({ }^{\circ} \mathrm{N} .\right)\end{array}$ & $\begin{array}{c}\text { Longitude } \\
\left({ }^{\circ} \mathrm{W} .\right)\end{array}$ & $\begin{array}{c}\text { Instal- } \\
\text { lation } \\
\text { date }\end{array}$ & $\begin{array}{l}\text { Magnifi- } \\
\text { cation at } \\
25 \mathrm{~Hz}\end{array}$ \\
\hline \multicolumn{5}{|l|}{ Present locations: } \\
\hline FGO & $14^{\circ} 26.74^{\prime}$ & $90^{\circ} 50.43^{\prime}$ & $2 / 73$ & 120,000 \\
\hline $\mathrm{CHI}$ & $14^{\circ} 35.69^{\circ}$ & $90^{\circ} 51.62$ & $2 / 75$ & 60,000 \\
\hline MMA & $14^{\circ} 32.28^{\prime}$ & $90^{\circ} 40.89^{\prime}$ & $2 / 75$ & 60,000 \\
\hline BVA & $14^{\circ} 40.00^{\prime}$ & $90^{\circ} 38.24^{\prime}$ & $2 / 73$ & 120,000 \\
\hline REC & $14^{\circ} 26.25^{\prime}$ & $90^{\circ} 31.36^{\prime}$ & $2 / 73$ & 120,000 \\
\hline TER & $14^{\circ} 18.25^{\prime}$ & $90^{\circ} 41.01^{\prime}$ & $2 / 75$ & 240,000 \\
\hline \multicolumn{5}{|l|}{1973 locations: } \\
\hline Chiquimula & $14^{\circ} 47.4^{\prime}$ & $89^{\circ} 33.6^{\prime}$ & $3 / 73$ & 120,000 \\
\hline Chiantla & $15^{\circ} 21.6^{\prime}$ & $91^{\circ} 27.0^{\prime}$ & $3 / 73$ & 60,000 \\
\hline
\end{tabular}

1 Station codes are listed in the Glossary.

val, however, only a few shallow-focus earthquakes locate along the fault system through Central Guatemala, which marks the boundary between the North American and Caribbean plates (Malfait and Dinkelman, 1972; Jordon, 1975). Included in this fault system is the Motagua fault (fig. 7) that was the source of the February 4 earthquake.

Figure 8 is a seismicity map of Guatemala based on 30 years of data recorded by the Wiechert seismograph at the Observatorio Nacional. The gain of this seismograph is 35 , and thus it is sensitive to earthquakes larger than roughly magnitude 2.0 in the vicinity of Guatemala City and larger than magnitude 5.5 at a distance of $200 \mathrm{~km}$. Earthquake epicenters are located only approximately by using the $\mathrm{S}-\mathrm{P}$-wave difference to calculate distance and $\mathrm{P}$ wave amplitudes on the two horizontal components to determine azimuth. In addition, felt earthquake reports sent to the Observatorio Nacional aid in verifying the locations. Therefore, this group of earthquakes is approximately equivalent to what would have been located by the WWNSS. Even though the epicenters are subject to large errors, these long-term data provide important data on the features of seismically active zones in Guatemala and their relative level of seismic activity over three decades.

The greatest concentration of seismic activity shown in figure 8 is along the Pacific coast of Guatemala and is probably associated with the Benioff zone that dips northeastward beneath the country. Recent results, from a seismic network in Nicaragua (Aburto, 1975), show that, in addition to the very active dipping Benioff zone, a separate but seismically less active zone of shallow earthquakes with depths less than $20 \mathrm{~km}$ occurs along the Nicaraguan chain of active volcanoes. Data from the six-station seismic net suggest that a similar group of shallow earthquakes occurs in the vicinity of the volcanoes near Guatemala City (fig. 10). Historically this

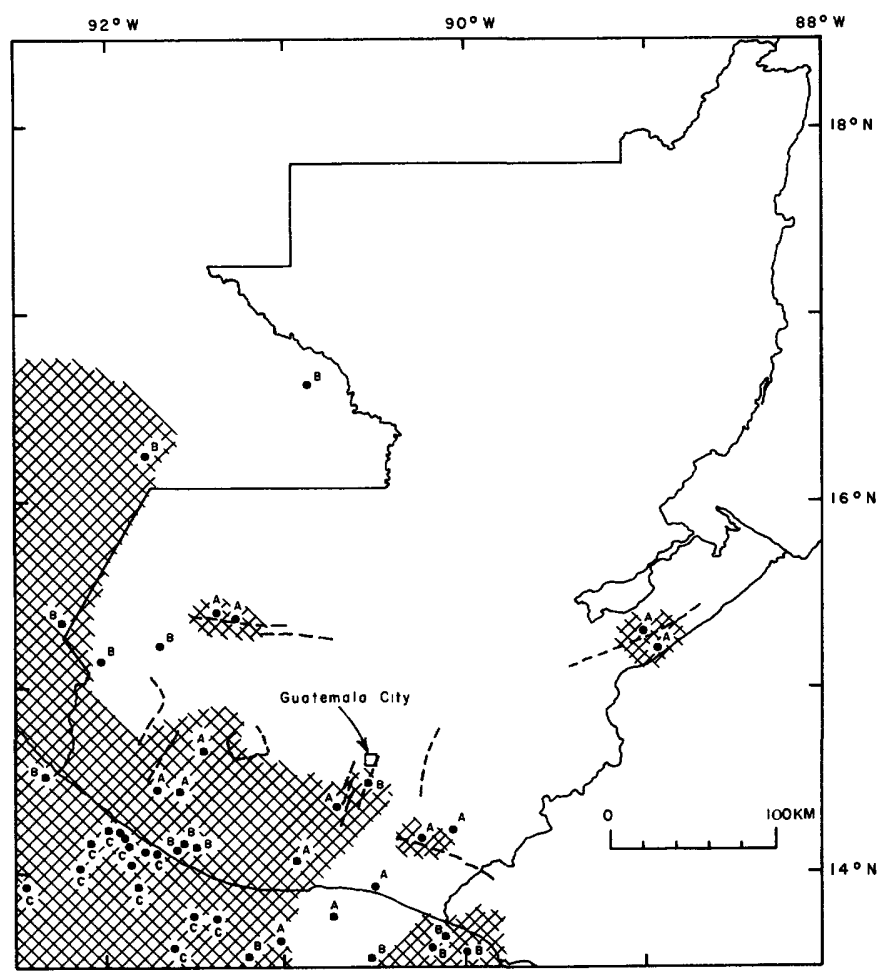

Figure 8.-Seismicity map for Guatemala (1945-75) compiled by J. Vassaux, Observatorio Nacional, Guatemala. Hatched areas are regions of frequent seismic activity. Dots indicate the number of earthquake series or swarms at specific areas during this period: $A$, fewer than 5 times; $B$, between 6 and 10 times; and C, more than 10 times.

shallow seismic zone is the source of moderatesized locally destructive earthquakes in Central America (Carr and Stoiber, 1976, unpub. data) including, most recently, the Managua earthquake of December 23, 1972, that damaged much of the capital city of Nicaragua. Therefore, the earthquakes in Guatemala that occur near the comparatively less seismically active northern boundary of the large hatched area shown in figure 8 may also be associated with shallow seismicity along the line of volcanoes. 
Two other small areas of relatively low-level seismic activity are located in figure 8 in west-central and east-central Guatemala. These areas lie along the fault system that runs across central Guatemala, and the eastern area occurs on the Motagua fault. Previous data (Molnar and Sykes, 1969), the extensive ground breakage on the Motagua, and its tectonic similarity to the San Andreas fault indicate that the earthquakes in these areas occur at shallow depths.

Thus, there are three sources of magnitude 4 or larger earthquakes in Guatemala, and their relative levels of seismic activity appear to have been constant for the last 30 years. The main source of seismicity is the zone of earthquakes that dips northeastward beneath the country. The other two sources are shallow and seismically less active. One lies along the chain of active volcanoes, and the other along the fault system that crosses central Guatemala. Historically, however, these shallow, relatively less active zones are the sources of the majority of moderate-sized locally destructive earthquakes. Although the deep shocks are more numerous, their depths, which are in the range of 50-250 $\mathrm{km}$ under the more heavily populated regions, lessen their threat by placing them at considerable distances from cities and towns.

\section{DISTRIBUTION OF S-P TIMES}

Distributions of $\mathrm{S}-\mathrm{P}$ times from the station at Fuego Volcano and the two stations temporarily installed along the fault zone in central Guatemala are plotted in figure 9. Approximately 10 percent of the recorded earthquakes could not be used, either because the arrival times were unclear or because the earthquake waves were large enough to exceed the dynamic range of the instruments, thereby making the $\mathrm{S}-\mathrm{P}$ time unreadable for $\mathrm{S}-\mathrm{P}$ intervals of less than 15 or $20 \mathrm{~s}$ (a unit $\mathrm{S}-\mathrm{P}$ interval is equivalent to a focal distance of about $8 \mathrm{~km}$ ). For earthquakes within $5 \mathrm{~km}$, the lowest detectable magnitudes are roughly estimated (Brune and Allen, 1967) to be 0.5 for Fuego and Chiquimula and 0.8 for Chiantla.

Events with $\mathrm{S}-\mathrm{P}$ times of less than $5 \mathrm{~s}$ were recorded at all stations, indicating that, at each site, local faults are active. For microearthquakes within $40 \mathrm{~km}$ of the stations, an average of 5.5 events per day were recorded at Fuego (Harlow and Ward, unpub. data, 1976), and about 1.0 event per day was recorded at Chiquimula and Chiantla. The higher seismicity at Fuego is probably related to its high level of recent volcanic activity. Local
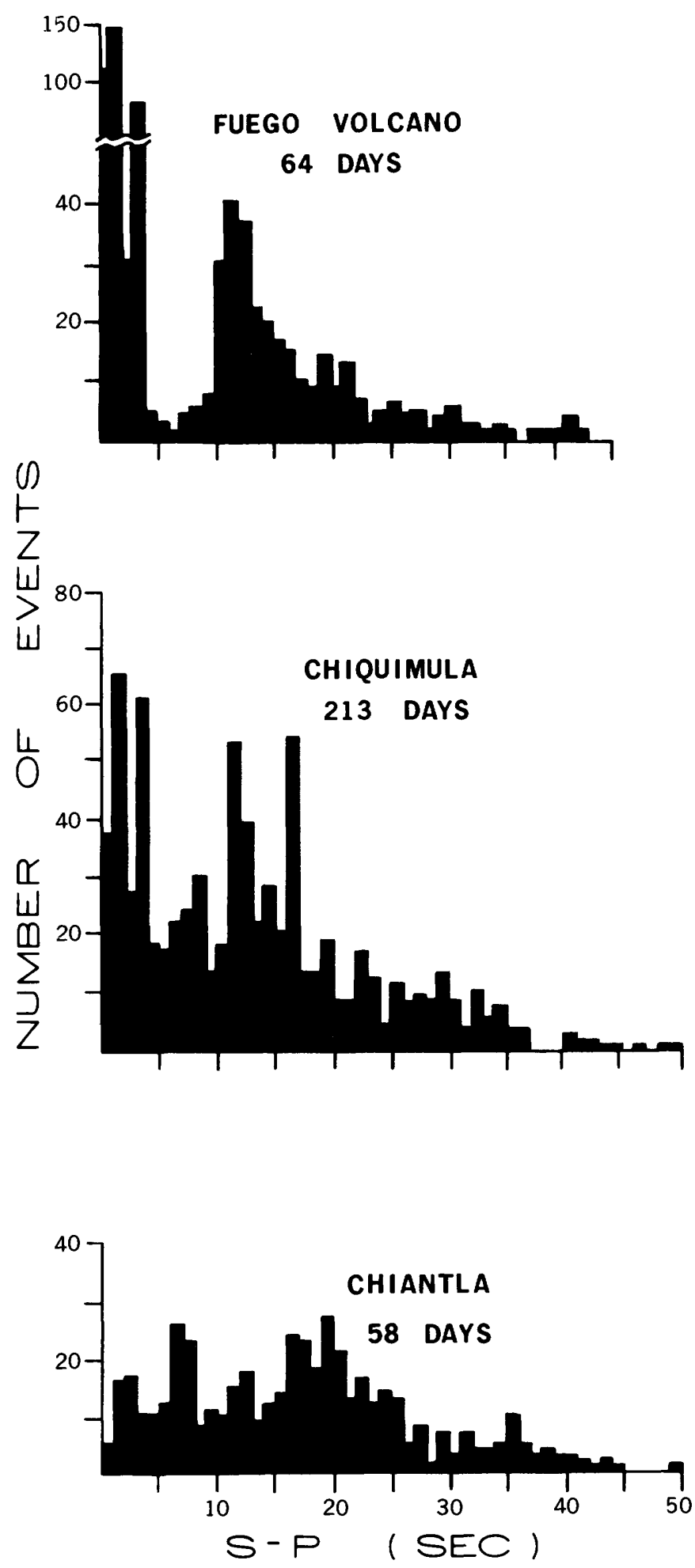

FIGURE 9.-Distribution of S-P times in seconds during 1973 at seismic stations in Guatemala. Useful recording days are noted for each station. 
seismicity near Fuego originates both on local faults and at the volcano. The Chiquimula station is 8 $\mathrm{km}$ north of the Jocotan fault and $25 \mathrm{~km}$ south of the Motagua fault. Thus, events with 1- to 2-s S-P times at Chiquimula likely occur on the Jocotán fault or on north-south-trending fractures in the Ipala graben just to the south of the Jocotán fault in this area (Carr, 1974). The numerous events with S-P times of 3 to $5 \mathrm{~s}$ could occur either on the above faults or on the Motagua fault. The data suggest that the Polochic fault is also seismically active in the vicinity of Chiantla. The events with $\mathrm{S}-\mathrm{P}$ times of 7 and $8 \mathrm{~s}$ and greater at Chiantla could originate on the western end of the Motagua fault. Thus, the occurrence of microearthquakes within $40 \mathrm{~km}$ of these seismograph stations indicates that the Polochic, Motagua, and Jocotán faults are probably seismically active.

Intermediate-depth earthquakes with magnitudes greater than 1.5 to 2.0 originating in the Benioff zone beneath the stations would be expected to produce peaks in the histograms at $\mathrm{S}-\mathrm{P}$ times of 10 to $14 \mathrm{~s}$. Peaks in this range occur at the Fuego and Chiquimula stations. There are no clear peaks in the distribution of $\mathrm{S}-\mathrm{P}$ times at Chiantla, however, possibly because of the relatively short recording time or the diffuse seismic activity in southeastern Mexico (Molnar and Sykes, 1969; see also fig. 8).

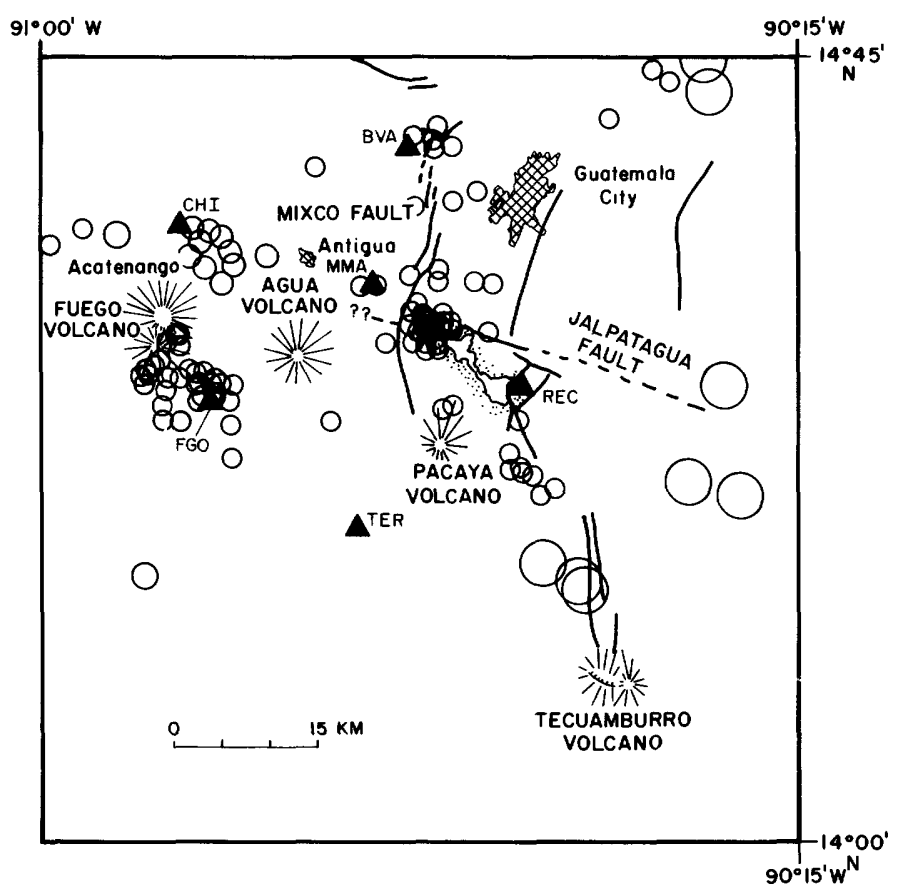

FIGURE 10.-Epicenter locations and known faults in the region of the six-station seismic network (solid triangles). The size of the circles reflects the estimated error in the calculated location. Station code is in the Glossary.

\section{SEISMIC ACTIVITY IN THE VICINITY OF GUATEMALA GITY}

Epicenters of shallow (less than $15 \mathrm{~km}$ deep) microearthquakes near Guatemala City are plotted in figure 10 . These data include 29 events recorded by the three-station network during 65 useful recording days in 1973 and 75 events recorded by the six-station network from March to September 1975. For earthquakes that occur inside or near the seismic network, magnitude 1 events are the smallest that can be located. The most intense seismicity occurs within $10 \mathrm{~km}$ of Fuego Volcano, which has had large eruptions in 1971,1973 , and 1974, plus minor eruptive activity in 1975 . These events, then, are probably related to eruptive processes at Fuego. Epicenters show that the Jalpatagua and Mixco faults are seismically active (ground breakage on the Mixco fault zone was caused by the February 4 earthquake). Other epicenters lie on or near other known faults in this area. Thus, the shallow seismicity indicates that there is a complex pattern of active faults near Guatemala City.

Events that may originate on the Motagua fault have not been systematically located because they are outside the network and their epicenters are therefore poorly determined. A check of all regional earthquakes recorded by the six-station network from March 1975 through January 1976 was made to determine how many events might have originated on the fault zone across Guatemala represented by the Polochic, Motagua, and Jocotan faults. Criteria used to identify regional events occurring at shallow focal depths north of the seismic net are: (1) relative arrival time at the seismic stations to roughly determine azimuth and (2) apparent velocities across the network of less than $10 \mathrm{~km} / \mathrm{s}$. The second criterion passes shallow earthquakes at distances up to approximately $175 \mathrm{~km}$ from the seismic net and discriminates against events that occur north of the seismic net but at depth on the Benioff zone. The lowest detectable magnitude for these earthquakes is about 1.5 for events on the Motagua fault nearest to Guatemala City and 4.0 for events at a distance of $150 \mathrm{~km}$. The results, listed by month in table 2, show that, at most, only 11 percent of the regional earthquakes could have originated on the Motagua fault during this period. In addition, no unusual activity such as swarms was observed. This, together with previous data from other sources, suggests that, although the Motagua fault is an historic source of large and damaging earthquakes, it is not continuously the most seismically active tectonic feature in Guatemala. 
TABLE 2.-Number of events each month originating from the central fault system compared with the number of all regional events

\begin{tabular}{|c|c|c|c|}
\hline & Date & $\begin{array}{l}\text { Possible } \\
\text { central } \\
\text { fault } \\
\text { system } \\
\text { events }\end{array}$ & $\begin{array}{c}\text { Total } \\
\text { regional } \\
\text { events }\end{array}$ \\
\hline \multirow[t]{10}{*}{1975} & March & 9 & 76 \\
\hline & April & 14 & 77 \\
\hline & May & 28 & 90 \\
\hline & June & & \\
\hline & July & ${ }^{1} 5$ & ${ }^{1} 43$ \\
\hline & August & 9 & 49 \\
\hline & September & 8 & 104 \\
\hline & October & 14 & 119 \\
\hline & November & 6 & 127 \\
\hline & December & 6 & 123 \\
\hline \multirow[t]{2}{*}{1976} & January & 8 & 124 \\
\hline & Total & $\overline{107}$ & 932 \\
\hline
\end{tabular}

1 The numbers of events for July are extrapolated from 22 useful recording days.

\section{SUMMARY}

Seismic data collected over an interval of about 30 years before the earthquake of February 4 reveal three main sources of seismic activity in Guatemala. The most intense source of seismic activity is a zone of earthquakes that dips northeastward beneath Guatemala and results from the Cocos plate being thrust under the Caribbean plate. The danger of this seismic zone is greatly reduced by the depths, and therefore the distance, of these events, which range from 50 to $250 \mathrm{~km}$ under the more heavily populated regions. During the interval of the last 30 years, the second and third source regions have consistently generated fewer shocks. The second source of earthquakes occurs at shallow depths along the chain of active volcanoes. This zone is historically the source of many moderate-sized, locally damaging earthquakes and, at least in the vicinity of Guatemala City, consists of many complexly related active faults. The third source is the fault system that cuts across central Guatemala and includes the Motagua fault, which was the source of the February 4 earthquake. During 1973 , about 1.0 local (within $40 \mathrm{~km}$ ) microearthquake per day was recorded at two high-gain seismograph stations installed on this fault system, suggesting that the Polochic, Motagua, and Jocotán faults are seismically active. During the 11 months preceding the February 4 earthquake, however, only 11 percent of all regional earthquakes recorded at a seismic network near Guatemala City could have originated from this fault system. Thus, the seismic zone that produced the most destructive earthquake in the recent history of Guatemala has exhibited a level of seismicity over the last 30 years that is lower than the prominent seismic activity that occurs on the deep seismic zone. 
THE GUATEMALAN EARTHQUAKE OF FEBRUARY 4, 1976, A PRELIMINARY REPORT

\title{
MAIN EVENT AND PRINCIPAL AFTERSHOCKS FROM TELESEISMIC DATA
}

\author{
By Waverly Person, William Spence, and James W. Dewey
}

The hypocenter of the main event of the Guatemala earthquake was determined by using stations available to the National Earthquake Information Service (NEIS) throughout the world. The preliminary hypocenter and origin time parameters are:

Origin time: 090143.3 UTC (03 0243.3 local time)

Latitude: $\quad 15.32^{\circ} \mathrm{N}$.

Longitude: $89.08^{\circ} \mathrm{W}$.

Depth: $\quad 5 \mathrm{~km}$ (constrained)

Magnitude: $\mathrm{M}_{\mathrm{s}}=\mathbf{7 . 5}$

The main event is located near Los Amates about $157 \mathrm{~km}$ northeast of Guatemala City on the Motagua fault. It should be emphasized that the hypocenter of the main event represents the point of the initial rupture. The fault break extends at least $160 \mathrm{~km}$ westward towards Guatemala City and $80 \mathrm{~km}$ towards the northeast (Plafker and others, this report).

Data from 90 stations were used in locating the main event, including readings from Guatemala. The wide distribution of these stations gives us reasonable confidence in the epicenter solution. Travel-time anomalies, however, could conceivably be producing a location bias of tens of kilometres; the preliminary location of the Managua, Nicaragua, earthquake of December 23, 1972, for example, was biased $25 \mathrm{~km}$ to the northeast of the true epicenter. In the case of the Guatemala earthquake, a component of location bias in the direction of the Motagua fault would be difficult to detect.

There were neither reliable teleseismic depth phases nor stations close enough to the epicenter of the Guatemala main event to enable us to estimate hypocentral depth with confidence. The hypocenter was restrained to a shallow depth, $5 \mathrm{~km}$, because of the surface faulting that accompanied the earthquake and because the depths of aftershocks located by Langer, Whitcomb, and Aburto (this report) were in the range 0-12 km. Computation with no depth restraint of the hypocentral parameters of the main event always yielded focal depths in the shallow crust, but these results could be fortuitous.

The magnitude is based on the average of surface-wave data from several stations. $M_{s}=7.5$ is consistent with amplitudes of $100-\mathrm{s}$ G-waves measured by Dewey and Julian (this report).

Short-period P-wave arrivals of the February 4 main event and subsequent aftershocks are generally emergent. The teleseismic records strongly suggest that the main event was a multiple rupture.

The February 4 main event was followed by damaging aftershocks. The two largest aftershocks (both $m_{b}=5.8$ ), as of March 7, 1976, occurred soon after the main event. These aftershocks occurred near Guatemala City, possibly on the north-south-trending Mixco fault (see fig. 7). Other 


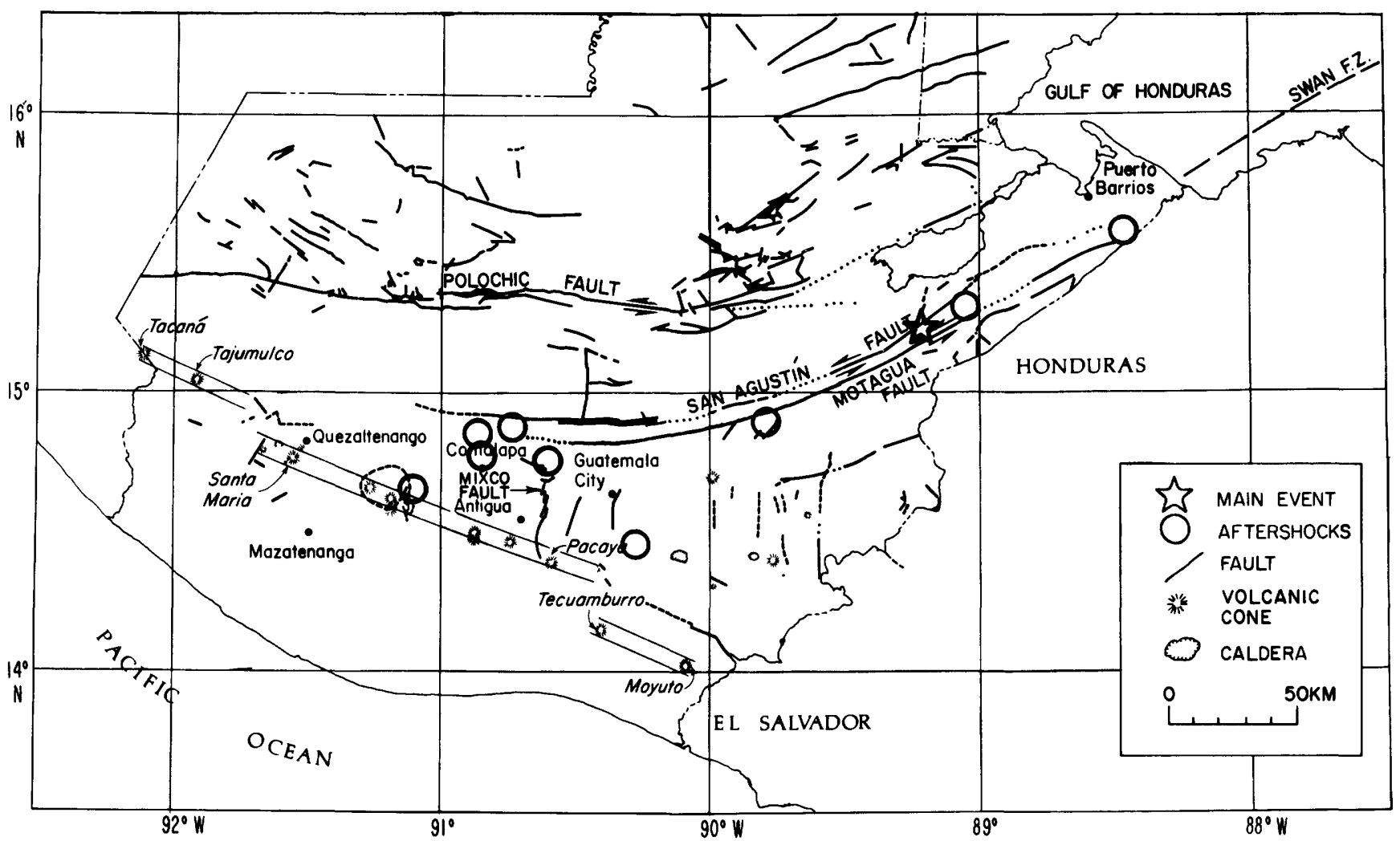

FiguRE 11.-Epicenters of main event and the principal aftershocks through March 7, 1976. These locations are based on data available as of April 5, 1976, and are subject to slight revision. Light parallel lines represent volcanic linears. (Base map modified from Bonis and others, 1970, and Plafker and others, this report.)

TABLE 3.-Epicenter location of aftershocks

\begin{tabular}{|c|c|c|c|c|c|}
\hline Date & Origin time & $\begin{array}{c}\text { Latitude } \\
\left({ }^{\circ} \mathrm{N} .\right)\end{array}$ & $\begin{array}{c}\text { Longitude } \\
\left({ }^{\circ} \mathrm{W} .\right)\end{array}$ & $\begin{array}{c}\text { Depth } 1 \\
(\mathrm{~km})\end{array}$ & Magnitude \\
\hline $\begin{array}{r}\text { Feb. } 4 \\
6 \\
6 \\
6 \\
8 \\
9 \\
9 \\
10 \\
\text { Mar. } 7 \\
7\end{array}$ & $\begin{array}{lll}09 & 30 & 28.3 \\
04 & 11 & 03.3 \\
18 & 11 & 59.2 \\
18 & 19 & 17.7 \\
08 & 13 & 51.9 \\
11 & 44 & 46.7 \\
06 & 17 & 43.0 \\
02 & 54 & 05.4 \\
03 & 15 & 40.3\end{array}$ & $\begin{array}{l}14.7 \\
14.6 \\
14.3 \\
14.7 \\
15.7 \\
15.3 \\
15.0 \\
14.9 \\
14.7\end{array}$ & $\begin{array}{l}90.6 \\
91.1 \\
90.2 \\
90.6 \\
88.5 \\
89.1 \\
89.7 \\
90.9 \\
90.5\end{array}$ & $\begin{array}{l}5 \\
5 \\
5 \\
5 \\
5 \\
5 \\
5 \\
5 \\
5\end{array}$ & $\begin{array}{l}5.8 \mathrm{~m}_{\mathrm{b}} \\
4.8 \mathrm{~m}_{\mathrm{b}} \\
5.2 \mathrm{~m}_{\mathrm{b}} \\
5.8 \mathrm{mb}_{\mathrm{b}} \\
5.7 \mathrm{M}_{\mathrm{S}} \\
5.1 \mathrm{~m}_{\mathrm{b}} \\
4.7 \mathrm{mb}_{\mathrm{b}} \\
4.8 \mathrm{~m}_{\mathrm{b}} \\
4.9 \mathrm{mb}_{\mathrm{b}}\end{array}$ \\
\hline
\end{tabular}

1 Constrained.

damaging aftershocks could have occurred immediately after the main event, and their seismic signatures could be buried in the coda of the main event. The $M_{s}=5.7$ aftershock of February 8 is near the eastern end of the surface-fault rupture. The two aftershocks in table 3 that are not alined with the Motagua fault zone lie immediately north of the central Guatemalan volcanic lineament shown in figure 11.

Table 3 is a list of preliminary origin times, epicentral coordinates, and magnitudes of the principal aftershocks occurring through March 7, 1976, as located by NEIS. Focal depth was restrained to $5 \mathrm{~km}$ in the aftershock hypocenter determination. Figure 11 shows epicenters of the main event and principal aftershocks. There were no foreshocks located by the NEIS, and we have no foreshocks recorded at high-gain stations at teleseismic distances. 
THE GUATEMALAN EARTHQUAKE OF FEBRUARY 4, 1976, A PRELIMINARY REPORT

\title{
MAIN EVENT SOURCE PARAMETERS FROM TELESEISMIC DATA
}

\author{
By James W. Dewey and Bruce R. Julian
}

\section{INTRODUCTION}

The Guatemala earthquake occurred on the Motaqua fault, a strike-slip fault thought to be part of the boundary between the Caribbean plate and the North American plate. The characteristics of the focal mechanism of the Guatemala earthquake are of considerable interest to U.S. seismologists, because there may be similarities between this fault and strike-slip faults in California that are also associated with plate boundaries. Conversely, the history of strike-slip earthquakes in California and other regions may help anticipate the future course of the aftershock sequence of the Guatemala earthquake.

\section{FOGAL MECHANISM}

The P-wave first-motion pattern of the main event is shown in figure 12 . The east-northeaststriking nodal plane corresponds to the fault plane of the earthquake. Motion across this plane is leftlateral strike-slip. The strike of the fault plane is well determined and is about N. $65^{\circ} \mathrm{E}$. Possible dips vary from $84^{\circ} \mathrm{N}$. to $82^{\circ} \mathrm{S}$. The motion is of almost pure strike-slip character. The fault plane in figure 12 agrees well with the geologically mapped fault trace.

\section{SEISMIC MOMENT}

The Guatemala earthquake produced mantle Love waves that had periods of around $100 \mathrm{~s}$ and that were well recorded by many seismographs of the WWNSS, from which the seismic moment of the earthquake can be determined. For this preliminary report, we estimated the displacement spectral density of the ground motion by multiplying the measured pulse amplitudes by $70 \mathrm{~s}$ for those phases with periods near $100 \mathrm{~s}$ (Brune and Engen, 1969). Amplitudes were normalized to an epicentral distance of $90^{\circ}$ (see Brune and Engen, 1969) with $Q$, the seis-

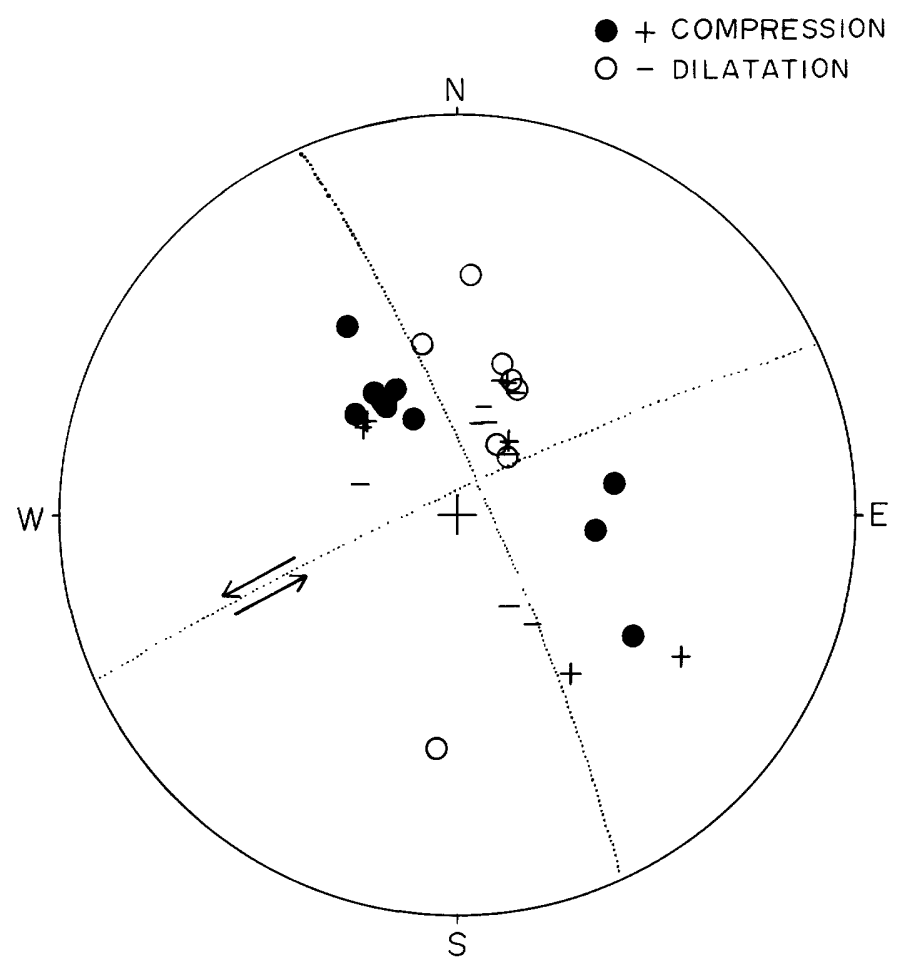

Figure 12.-Stereographic projection of P-wave first motions for the main event. Circles represent first motions especially measured for this study. Plus and minus represent first-motion data reported to the NEIS. The solution has been chosen to be consistent with all the readings made by us and, in addition, to be as consistent as possible with the first motions reported to the NEIS. The northeast-striking nodal plane corresponds in strike and sense of displacement to the Motagua fault.

mic quality factor, taken to be 107 and the group velocity of the G-wave taken to be $4.4 \mathrm{~cm} / \mathrm{s}$ (table 4 and fig. 13). These spectral densities were then adjusted for the orientation of the focal mechanism, assuming a vertical strike-slip fault as the earthquake source. More accurate determinations based on Fourier analysis of digitized records are planned. 
TABLE 4.-Distance, azimuths, and spectral density for G-waves

\begin{tabular}{|c|c|c|c|c|c|}
\hline Station ${ }^{1}$ & Phase 2 & (degrees) $^{3}$ & $\underset{\text { (degrees) }}{\stackrel{\theta}{*}}$ & $\begin{array}{l}\text { Spectral density } \\
\text { at } 90^{\circ} \\
\text { (cm-s) }\end{array}$ & $\begin{array}{l}\text { Spectral density }{ }^{6} \\
\text { corrected for } \\
\text { focal mechanism }\end{array}$ \\
\hline $\begin{array}{l}\text { SJG } \\
\text { SJG } \\
{ }^{7} \text { KIP } \\
{ }^{7} \text { PRE } \\
\text { ALQ }\end{array}$ & $\begin{array}{l}\text { G2 } \\
\text { G4 } \\
\text { G3 } \\
\text { G2 } \\
\text { G3 }\end{array}$ & $\begin{array}{l}337.7 \\
697.7 \\
425.1 \\
239.1 \\
385.0\end{array}$ & $\begin{array}{l}14.5 \\
14.5 \\
41.8 \\
46.1 \\
79.8\end{array}$ & $\begin{array}{l}7.11 \\
5.06 \\
2.88 \\
1.98 \\
6.65\end{array}$ & $\begin{array}{l}5.18 \\
3.68 \\
\\
4.52\end{array}$ \\
\hline $\begin{array}{l}\text { DUG } \\
\text { LON } \\
\text { GOL } \\
\text { GIE } \\
{ }^{7} \text { WES }\end{array}$ & $\begin{array}{l}\text { G3 } \\
\text { G3 } \\
\text { G3 } \\
\text { G2 } \\
\text { G3 }\end{array}$ & $\begin{array}{l}392.2 \\
401.5 \\
388.1 \\
334.1 \\
391.1\end{array}$ & $\begin{array}{r}80.0 \\
81.0 \\
88.0 \\
118.8 \\
141.2\end{array}$ & $\begin{array}{l}5.09 \\
5.10 \\
6.39 \\
5.40 \\
2.48\end{array}$ & $\begin{array}{l}3.45 \\
3.41 \\
4.08 \\
6.42\end{array}$ \\
\hline $\begin{array}{l}\text { : KIP } \\
\text { : } \mathrm{PRE} \\
\text { ' GUA } \\
\text { ALQ } \\
\text { ALQ }\end{array}$ & $\begin{array}{l}\text { G2 } \\
\text { G3 } \\
\text { G2 } \\
\text { G2 } \\
\text { G4 }\end{array}$ & $\begin{array}{l}294.9 \\
480.9 \\
240.7 \\
335.0 \\
695.0\end{array}$ & $\begin{array}{l}221.8 \\
226.1 \\
230.4 \\
259.8 \\
259.8\end{array}$ & $\begin{array}{r}2.41 \\
1.78 \\
1.49 \\
8.65 \\
13.35\end{array}$ & $\begin{array}{l}5.88 \\
9.07\end{array}$ \\
\hline $\begin{array}{l}\text { DUG } \\
\text { DUG } \\
\text { LON } \\
\text { LON } \\
\text { GOL }\end{array}$ & $\begin{array}{l}\text { G2 } \\
\text { G4 } \\
\text { G2 } \\
\text { G4 } \\
\text { G2 }\end{array}$ & $\begin{array}{l}327.8 \\
687.8 \\
318.5 \\
678.5 \\
331.9\end{array}$ & $\begin{array}{l}260.0 \\
260.0 \\
261.0 \\
261.0 \\
268.0\end{array}$ & $\begin{array}{l}5.21 \\
8.69 \\
4.38 \\
5.10 \\
5.30\end{array}$ & $\begin{array}{l}3.53 \\
5.89 \\
2.93 \\
3.41 \\
3.38\end{array}$ \\
\hline $\begin{array}{l}\text { COL } \\
\text { COL } \\
\text { GIE } \\
{ }^{7} \text { GEO } \\
{ }^{7} \text { WES }\end{array}$ & $\begin{array}{l}\text { G2 } \\
\text { G4 } \\
\text { G3 } \\
\text { G2 } \\
\text { G2 }\end{array}$ & $\begin{array}{l}297.8 \\
657.8 \\
375.9 \\
334.1 \\
328.9\end{array}$ & $\begin{array}{l}270.9 \\
270.9 \\
298.8 \\
317.2 \\
321.2\end{array}$ & $\begin{array}{l}5.89 \\
5.86 \\
7.80 \\
2.46 \\
2.99\end{array}$ & $\begin{array}{l}3.75 \text { (median) } \\
3.73 \\
9.27\end{array}$ \\
\hline $\begin{array}{l}\text { PTO } \\
\text { PTO }\end{array}$ & $\begin{array}{l}\text { G2 } \\
\text { G4 }\end{array}$ & $\begin{array}{l}286.8 \\
646.9\end{array}$ & $\begin{array}{l}346.2 \\
346.2\end{array}$ & $\begin{array}{l}5.11 \\
7.42\end{array}$ & $\begin{array}{l}3.67 \\
5.33\end{array}$ \\
\hline
\end{tabular}

1 Station code listed in Glossary.

- Phase: defined in Glossary.

3 Distance traveled by G-wave from source to station.

4Azimuth from source to station of the phase in question, measured clockwise from the direction of fault rupture propagation (S. $65^{\circ}$ W.).

Spectral density at $90^{\circ}$, estimated by multiplying the ground displacement by $70 \mathrm{~s}$ and applying the distance correction factor of Brune and Engen (1969)

${ }^{B}$ The correction factor, assuming a vertical strike-slip fault, is $[\pi / 2 \cos 2 \theta]^{-1}$.

3 These stations were within $15^{\circ}$ of a G-wave nodal plane and have not been used in the computation of moment.

Several of our stations lay near nodes of the theoretical Love-wave radiation pattern (fig. 13). Because the radiation-pattern correction for these stations is subject to large uncertainty, we used in the computation of seismic moment only those stations that were well removed (more than $15^{\circ}$ ) from the theoretical nodal planes (table 4). The mean of the adjusted displacement spectral densities is $4.77 \pm 0.43$ $\mathrm{cm}-\mathrm{s}$; the median is $3.75 \mathrm{~cm}-\mathrm{s}$. The mean seems unduly influenced by a few large values, and we take the median as more representative of the sample as a whole. The seismic moment corresponding to a displacement spectral density of $3.75 \mathrm{~cm}-\mathrm{s}$ is $2.6 \times 10^{27}$ dyne-cm (Brune and Engen, 1969).

The provisional surface-wave magnitude assigned to the main event was $\mathrm{M}_{\mathrm{S}}=7.5$ (Person and others, this report). The amplitudes of 100 -s surface waves do not support a major adjustment of this magnitude; the moment computed from these amplitudes falls in the middle of the "cloud" of data points in Brune and Engen's (1969) graph of 20-s surfacewave magnitude versus moment.
SOURCE DIMENSIONS, DISPLACEMENT, STRESS DROP, AND DIRECTION OF FAULT PROPAGATION

The zone of the largest $(M>5.0)$ best located aftershocks of the main event, occurring during the first week, is about $250 \mathrm{~km}$ long (Person and others, this report). This zone of the largest aftershocks coincides very closely with the zone of surface faulting mapped after the earthquake (Plafker and others, this report). Possibly an additional $50 \mathrm{~km}$ of fault rupture could be postulated on the basis of small aftershocks recorded after the earthquake (Langer and others, this report) and from high damage west of Guatemala City (Espinosa and others, this report). For the purpose of the analysis that follows, we shall take the fault length as 300 $\mathrm{km}$.

The relationship between seismic moment $\left(M_{0}\right)$, fault length $(L)$, width $(w)$, and average displacement $(\bar{D})$ is (Aki, 1966)

$$
M_{\mathrm{o}}=\mu L w \bar{D},
$$




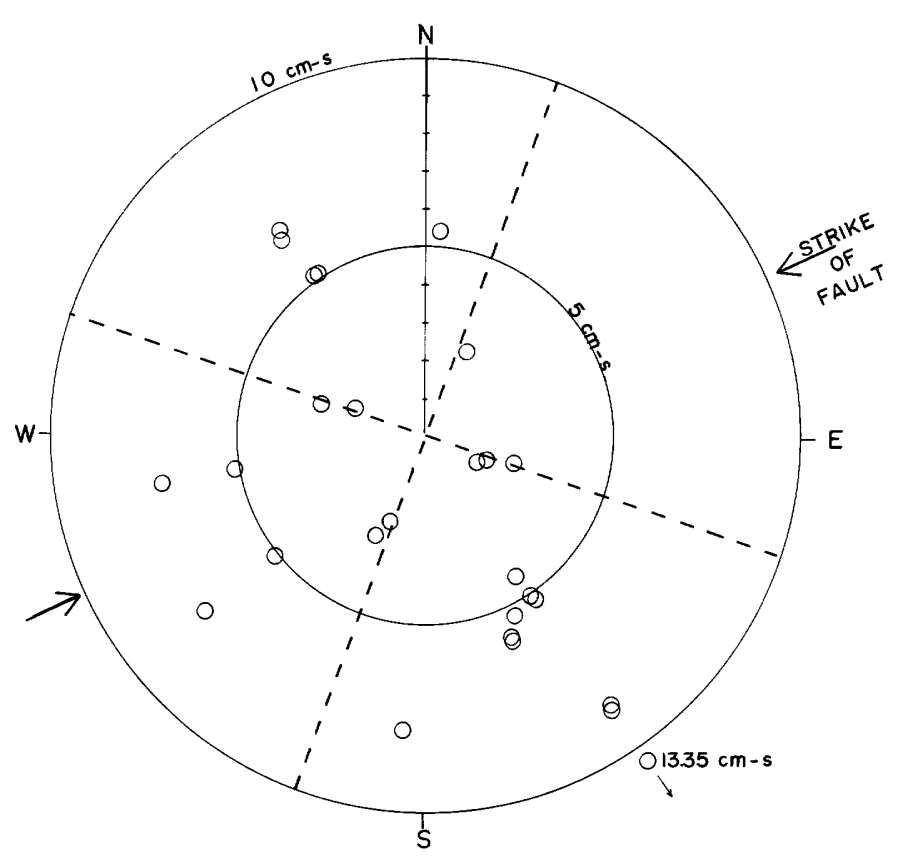

FIGURE 13.-Azimuthal variation of the displacement spectral density normalized to an epicentral distance of $90^{\circ}$. The dashed lines are theoretical nodal lines of the Love-wave radiation pattern for a vertical strike-slip fault, striking N. $65^{\circ} \mathrm{E}$.

where $\mu$ is the rigidity of the faulted medium, here taken to be $3 \times 10^{11}$ dynes $\mathrm{cm}^{-2}$. The average displacement, $\bar{D}$, is inferred from geologic observation to be $100 \mathrm{~cm}$ (Plafker and others, this report). Together with our estimate of seismic moment, a fault length of $300 \mathrm{~km}$ and an average displacement of $100 \mathrm{~cm}$ implies

$$
w=29 \mathrm{~km} \text {. }
$$

This fault width is apparently greater than those of earthquakes on California's San Andreas fault; the seismogenic fault width associated with the California earthquake of 1906, for example, is thought to be $10 \mathrm{~km}$ (Thatcher, 1975).

If we had chosen $M_{0}$ equal to the mean rather than the median of the moments observed at individual stations, if we had taken $L=250 \mathrm{~km}$ rather than $L=300 \mathrm{~km}$, and if we had taken $\bar{D}$ less than $100 \mathrm{~cm}$, the discrepancy between the fault width of the Guatemala earthquake and that of the 1906 California earthquake would be even greater. There are alternative explanations for this discrepancy:

1. Displacement on the fault at depth may be larger than surface-fault displacement, so that $100 \mathrm{~cm}$ would be significantly smaller than the actual $\bar{D}$. The difficulty with this explanation is that the displacements observed at the surface are quite uniform over long distances (Plafker and others, this report); it is hard to visualize a process acting uniformly over 100 or more kilometres that would retard surface-fault slippage relative to slippage at depth. In fact, one might make the contrary argument-that seismic-fault displacement on a long strike-slip fault will have a tendency to decrease with depth from the free surface.

2. Seismic rupture on the Motagua fault may actually have extended to several tens of kilometres in depth. Such rupture would have to produce a large amount of long-period energy in order to significantly affect amplitudes of 100-s G-waves. However, the fault rupture at depth need not necessarily have produced a large amount of short-period energy. Likewise, the shallow depths of aftershocks recorded by Langer, Whitcomb, and Aburto (this report) do not preclude fault rupture extending several tens of kilometres into the crust, since such rupture could occur comparatively slowly in a medium that is incapable of producing high-frequency strike-slip earthquakes.

The stress drop, $\Delta \sigma$, for the main event may be estimated from

$$
\Delta \sigma=\frac{2}{\pi} \mu\left(\frac{\bar{D}}{w}\right) \text { (Knopoff, 1958). }
$$

With $\mu=3 \times 10^{11}$ dynes $\mathrm{cm}^{-2}, \bar{D}=100 \mathrm{~cm}$, and $w=29$ $\mathrm{km}$,

$$
\Delta \sigma=6.6 \text { bars. }
$$

A stress drop of 6.6 bars is less than the worldwide average for interplate earthquakes; Kanamori and Anderson (1975) find that 30 bars is typical for such earthquakes. If, as discussed above, $w$ were less than $29 \mathrm{~km}$, the stress drop would be correspondingly larger.

The epicenter of the main event lay about $90 \mathrm{~km}$ from the eastern end of the inferred $300-\mathrm{km}-10 n g$ zone of fault rupture, a position that suggests that the fault rupture propagated from northeast to southwest. The level of shaking near the western end of the fault might be expected, under such circumstances, to be higher than the level of shaking at the eastern end of the fault because of constructive interference of waves from the propagating source. The mantle-wave observations tend to support such a conclusion, the amplitudes being larger for waves leaving the event to the southwest 

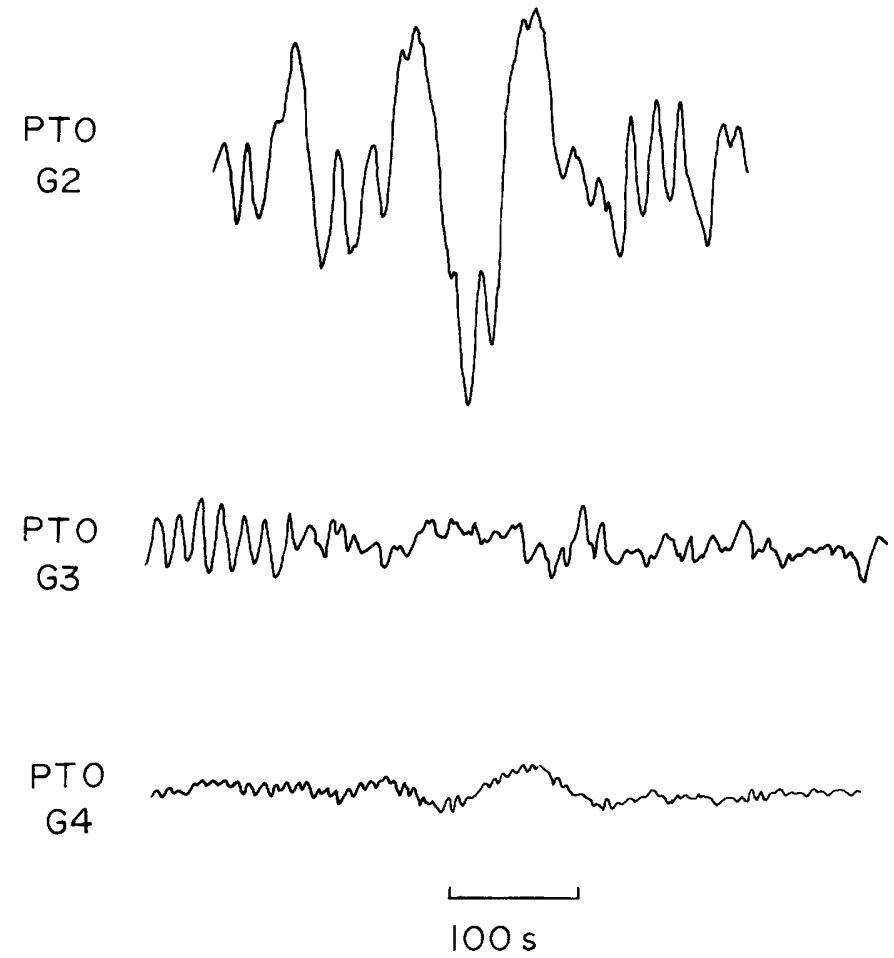

FIGURE 14.-Effect of source propagation on G-wave amplitudes at station PTO. G2 and G4 left the source at an angle of about $15^{\circ}$ from the direction of fault rupture. G3 left the source at an angle of $165^{\circ}$ from the direction of fault rupture. Note that the amplitude of G4 is at least equal to that of G3, although G4 has traveled $213.6^{\circ}$ farther than G3.

than for those leaving toward the northeast. Figure 14 shows a striking case of this phenomenon in the records from Pôrto, Portugal. The high intensities observed near the western end of the Motagua fault (Espinosa and others, this report) may thus be, in part, an effect of source propagation.

\section{FUTURE EARTHQUAKES ON THE MOTAGUA FAULT SYSTEM}

At the time this paper was written (April 1976), Guatemala had experienced several moderate $(5<\mathrm{M} \leq 6)$ aftershocks. In order to anticipate the future activity of the Motagua fault, we may study the seismic history of other major continental strike-slip faults. We shall consider the North Anatolian fault system, the seismicity of which one of us (Dewey, 1976) has recently studied. The following conclusions seem consistent also with the history of large earthquakes on California's San Andreas fault; they may therefore be valid for other major continental strike-slip faults like the Motagua fault:

1. Major earthquakes, involving hundreds of kilometres of fault rupture, do not tend to recur on the same segment of a strike-slip fault within a short period of time. This conclusion is based on the three Anatolian earthquakes comparable in size to the Guatemala earthquake: those of December 26, 1939, November 26, 1943, and February 1, 1944, none of which have yet been followed by earthquakes of comparable size on the same section of the fault. Likewise, neither of the great San Andreas earthquakes of January 9, 1857, or April 18, 1906, has yet been followed by another great earthquake on the same section of the fault.

2. Large sections of a strike-slip fault ruptured in a large earthquake will not produce aftershocks of magnitude greater than 5 . This conclusion is based on the characteristics of aftershocks of the Anatolian earthquakes; it is consistent with reports of aftershocks to the San Andreas earthquake of 1906 (Dewey, 1976). To date, this conclusion seems to be valid for the Guatemala earthquake.

3. Those moderate aftershocks that do occur will tend to be concentrated near the ends of the fault rupture. This has thus far been the case with the Guatemala earthquake; the largest aftershocks $(M \geq 5.5)$ have occurred near Guatemala City, at the western end of the fault break, and near the eastern end of the fault break (Person and others, this report).

4. Regions near the ends of the fault rupture may continue to experience moderate earthquakes for some years following the main event. It seems apparent that occurrence of the large shock does not significantly reduce the level of tectonic strain in the regions near the ends of the fault rupture. In fact, on theoretical grounds, the occurrence of the major earthquake should produce high tectonic strain near the extremities of the fault rupture (Chinnery, 1963).

For Guatemala, conclusions 1-4 imply that most of the Motagua fault ruptured by the earthquake will be seismically inactive during the next decades. The regions near the ends of the main fault rupture, near Guatemala City and south of Puerto Barrios, may, however, have several moderate earthquakes $(5<\mathrm{M}<6)$ in the coming decade.

There is also the possibility that the occurrence of the main event could induce, in the next several decades, a major earthquake on a segment of the Motagua fault adjacent to the fault ruptured by the February 4 earthquake. Such a migration of seismic 
sources over a period of several decades seems to have occurred on the North Anatolian fault and has also been postulated for the San Andreas fault (Savage, 1971).

There seems to be ample fault length to generate a major earthquake east of the rupture of February 4 where the Motagua fault trends into the tectoni- cally similar Swan fracture zone in the Gulf of Honduras (Spence and Person, this report). In the west, the likelihood of a future major earthquake, similar to this earthquake but centered to the west of it, may depend on whether the Motagua fault persists for hundreds of kilometres as a continuous fault west of the fault rupture of February 4, 1976. 
THE GUATEMALAN EARTHQUAKE OF FEBRUARY 4, 1976, A PRELIMINARY REPORT

\title{
STRONG-MOTION RECORDINGS OF THE MAIN EVENT AND FEBRUARY 18 AFTERSHOCK
}

\author{
By Charles F. Knudson
}

\section{INTRODUCTION}

The seismic history of Guatemala includes many destructive earthquakes (Person and others, this report). In 1773, the former capital, Antigua, was destroyed. A series of earthquakes beginning on November 17,1917 , and continuing with shocks on December 25 and 29 and also on January 3 and 24, 1918, destroyed Guatemala City. In the last 50 years, Guatemala has felt many strong earthquakes, but, until the series in February, none were of sufficient magnitude to cause the destruction experienced in the past.

Two strong-motion accelerographs and three seismoscopes were located in Guatemala City at the time of the February earthquakes. One accelerograph, an RFT-250, had not been reinstalled following repairs. The second accelerograph, a Montana type, was operational, but the lamp burned out at the time of the earthquake. The only records obtained were from the two seismoscopes, which were installed at the Universidad de San Carlos.

\section{SEISMIC INSTRUMENTATION}

The first useful seismograms from Guatemala were obtained in March 1919 from the Wiechert instruments donated to Guatemala by Georgetown University. These instruments, two horizontal and one vertical, have registered 20 to 39 shocks annually since initial installation. The seismic station of the Observatorio Nacional is a three-story 9.9 $\times 13.7-\mathrm{m}$ building. There is one story below ground level and two above. The portion of the building below ground level and the first story above ground level are of concrete frame with brick-filler walls. The third story is of wood frame construction. The first and second stories of the building serve to house a second building, or vault, that is built of concrete framing with brick-filler walls and is the seismograph and accelerograph vault. In May 1947, the 30-cm Montana-type accelerograph was installed. Numerous records have been obtained since installation of this accelerograph, but none have been of any engineering significance.

The Centro de Investigaciones de Ingeniería of the Universidad de San Carlos purchased one RFT250 accelerograph and three seismoscopes in the late 1960's. Two of the seismoscopes were installed in the administration building of the university, one on the ground floor and the second on the roof. The other seismoscope was installed in the Engineering Laboratory Building but was not deployed at the time of the February earthquakes. It was removed early in 1975 and taken to the Observatorio Nacional for repair. Although repaired and operational in July of 1975 , it had not been reinstalled when the February earthquakes occurred.

Four SMA-1 accelerographs were sent to Guatemala by the U.S. Geological Survey after the main event. In view of the distribution of the epicenter locations for the February 6, 8, 9, and 10 earthquakes, along with a fault length of more than 240 $\mathrm{km}$ (Plafker and others, this report) on the Motagua fault and secondary faulting in the Mixco area, it was decided to deploy the SMA-1 accelerographs at Puerto Santo Tomás, Zacapa, and Chichicastenango. An additional accelerograph and a seismoscope were later deployed in the center of Guatemala City at the IBM building (fig. 15). These four accelerographs were installed as temporary aftershock strong-motion instruments, and they will be removed in 2 or 3 months.

\section{SEISMOSCOPE RECORDS OF MAIN EVENT}

The two seismoscope records were recovered on February 10,1976 . The administration building at the university is a four-story building with dimensions of $29.76 \times 59.46 \mathrm{~m}$. The seismoscope plate (fig. 16) from the instrument on the roof of the building 


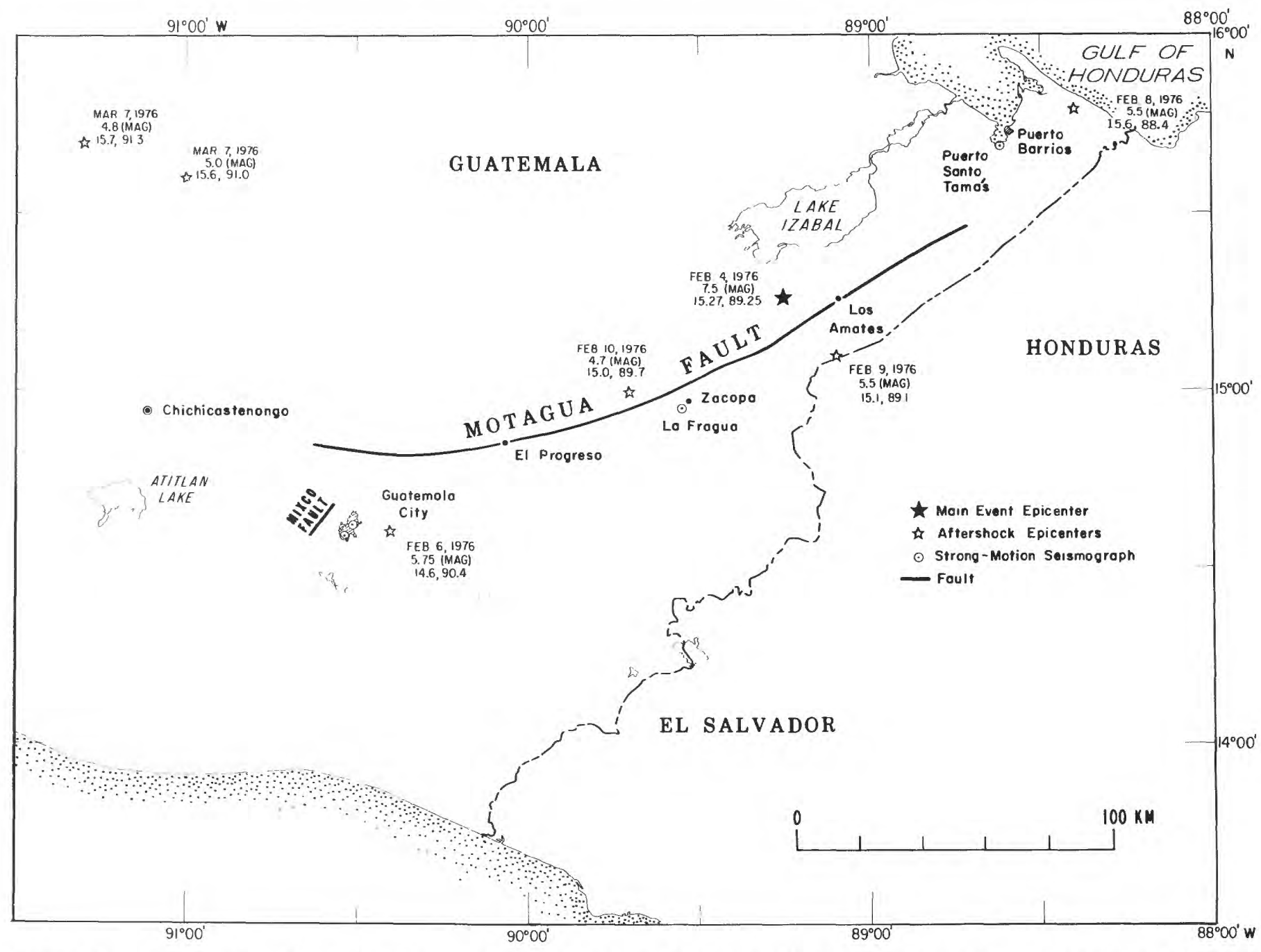

FIGURE 15.-Strong-motion field network, surface fault breakage (Plafker and others, this report), and epicenters of main event and aftershocks. Date, magnitude, and location are given for each (Person and others, this report).

had been dislodged. The ground motion on this record exceeded the maximum radius of the plate before it was dislodged. The trace on the seismoscope plate of the ground floor (fig. 17) had a maximum relative displacement of $S_{0}=5.3 \mathrm{~cm}$ for $T_{1}=0.78 \mathrm{~s}$, and a 10-percent damping.

Two sections of the maximum excursions of the recorded motion on the ground-floor seismoscope were analyzed in order to recover the levels of ground accelerations. Part of the trace between the two analyzed sections could not be followed, but it is certain that section one was first real time. The following constants were used in the analysis of the deconvolution of the seismoscope plate: $T_{1}=0.78$ $\mathrm{s}$ (natural period of seismoscope), $T_{2}=0.055 \mathrm{~s}$ ( $\mathrm{sec}$ ond harmonic of seismoscope), and $S=5.8 \mathrm{~cm} / \mathrm{rad}$, (sensitivity of seismoscope). The $T_{2}$ and $\mathrm{S}$ values are average determinations obtained from similar seismoscopes, and the other constants were obtained in the field calibration of these instruments.

The results of the above analysis are shown in figures 18 and 19. These two figures show the acceleration as a function of time for the north and east direction of motion. The first section was followed for $2 \mathrm{~s}$, and the second section for $5 \mathrm{~s}$. Maximum accelerations as shown are about 200 gals. A 600-gal acceleration appeared on the north directional component at approximately $1 \mathrm{~s}$ after the beginning of the second section. Unfortunately, there is insufficient recoverable trace length, and hence the data available do not warrant a spectral-analysis evaluation, since the time window is very short. 


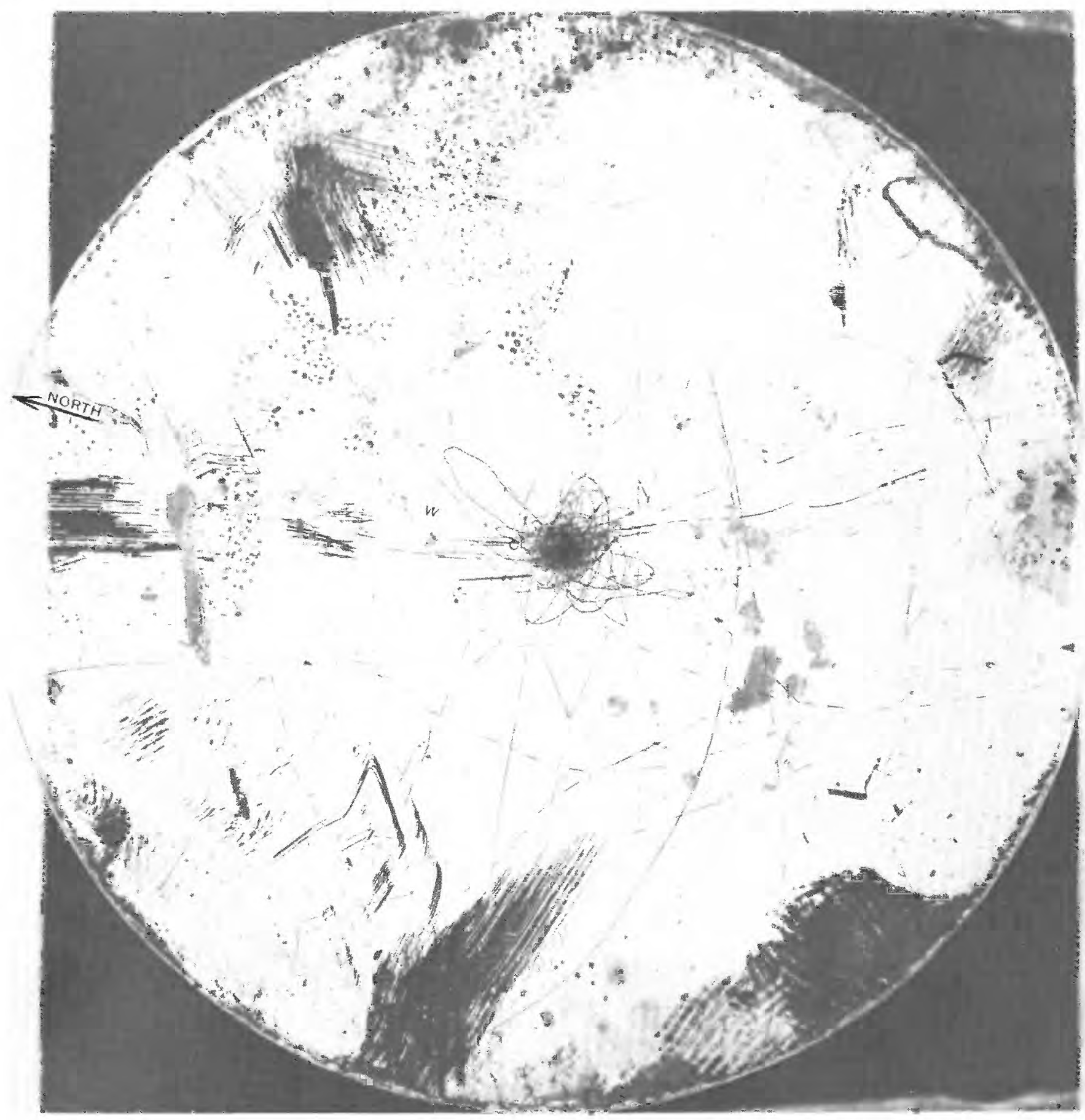

FIGURE 16.-Seismoscope plate of main event located on a rooftop instrument at the administration building of the Universidad de San Carlos, Guatemala City. Instrument was about $30 \mathrm{~km}$ south of Motagua fault surface breakage. Arrow indicates north. The plate is scratched all over. Recording of main event is shown in the middle part of plate and to the sides before dislodging. 


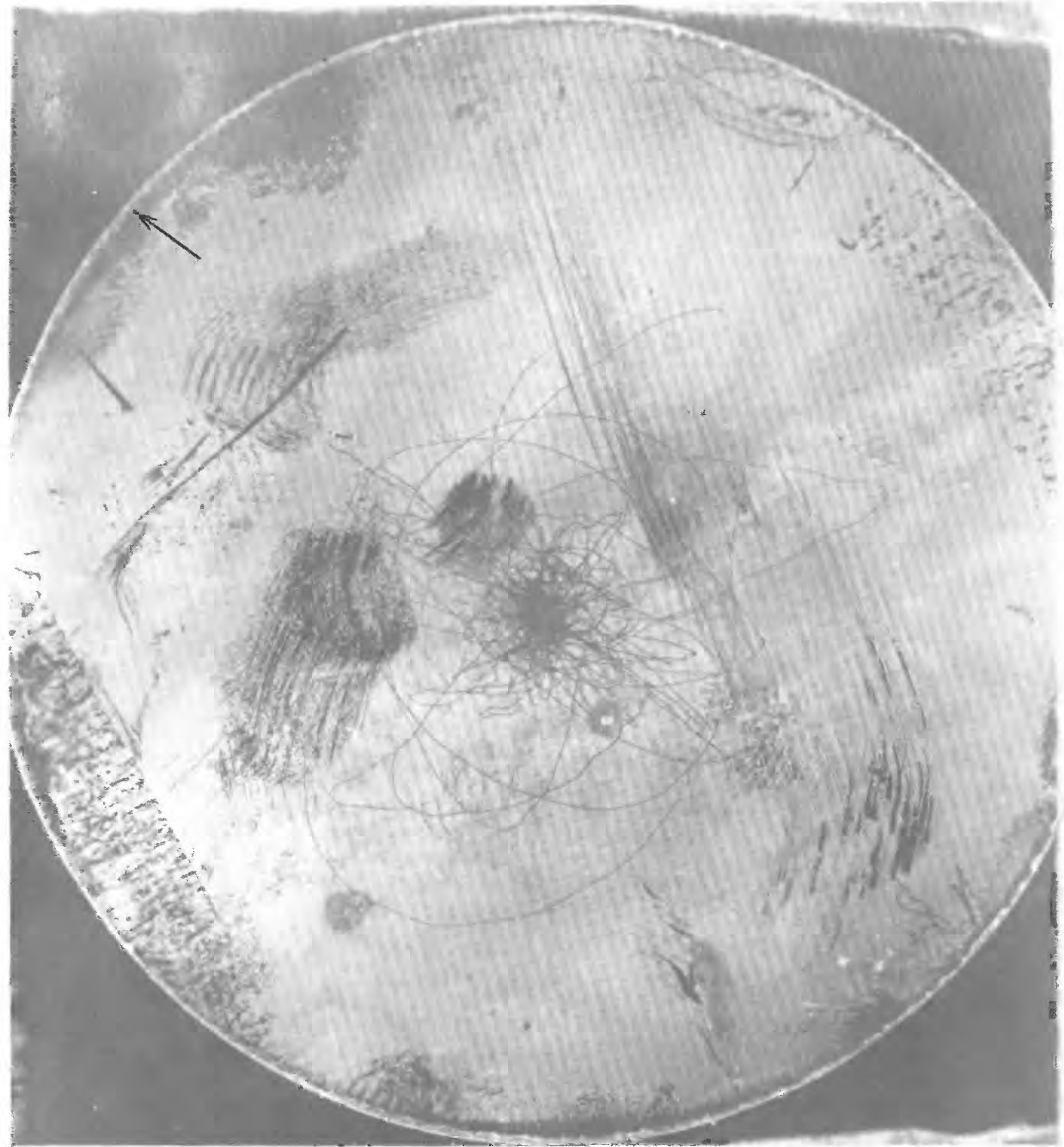

FIGURE 17.--Seismoscope plate of main event located on a ground-floor instrument at the administration building of the Universidad de San Carlos, Guatemala City. Instrument was about $30 \mathrm{~km}$ south of Motagua fault surface breakage. Arrow indicates north. The plate is scratched all over. Recording of main event is shown in middle part of plate. 


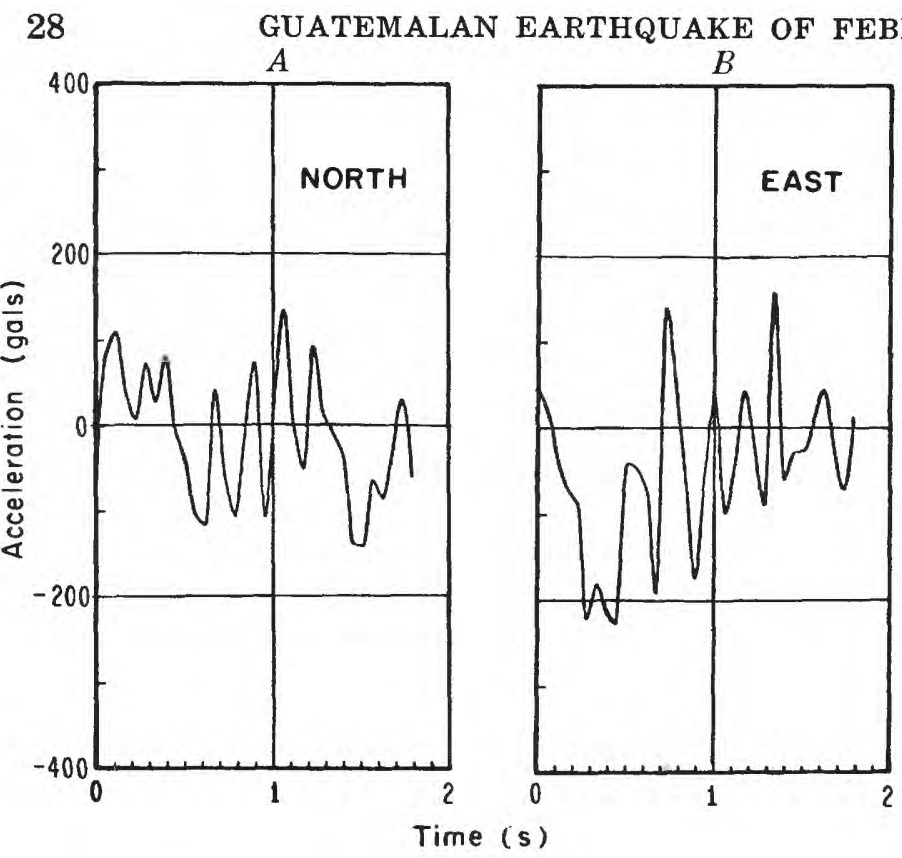

FigurE 18.-Deconvolved 2-s section of seismoscope of the main event. Acceleration as a function of time. $A$, North component; $B$, east component.

Figure 19.-Deconvolved 5-s section of seismoscope of the main event. Acceleration as a function of time. These 5 $s$ of recordings are later than those shown in figure 18. $A$, North component; $B$, east component.
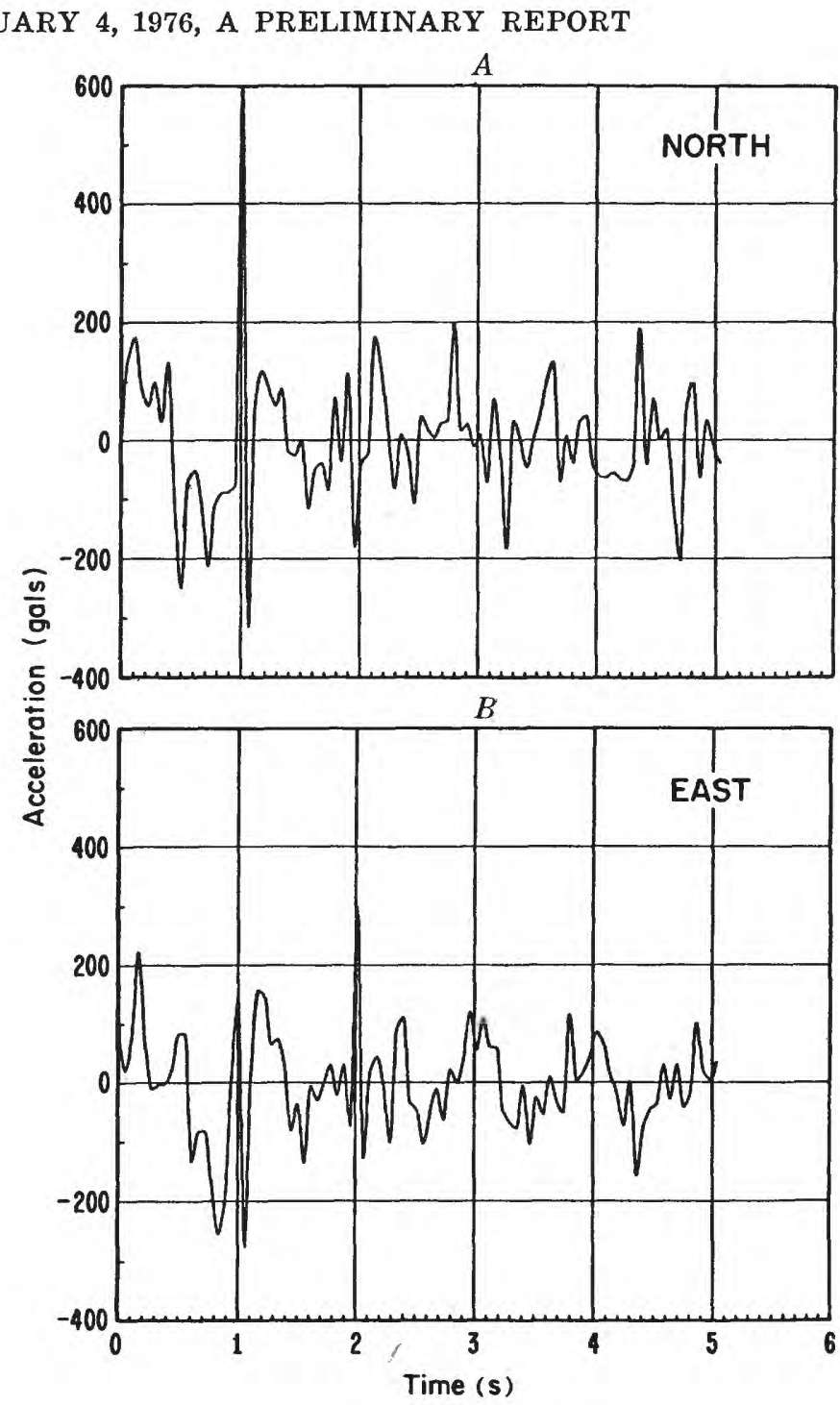

FiguRe 20.-Accelerogram of the February 18, 1976, aftershock recorded in Guatemala City by SMA-1, No. 1926, at station IBM building, lat $14.64^{\circ} \mathrm{N}$, long $90.51^{\circ} \mathrm{W}$.

$\nabla$ (Sens.=sensitivity; Per.=period; crit.=critical. $)$

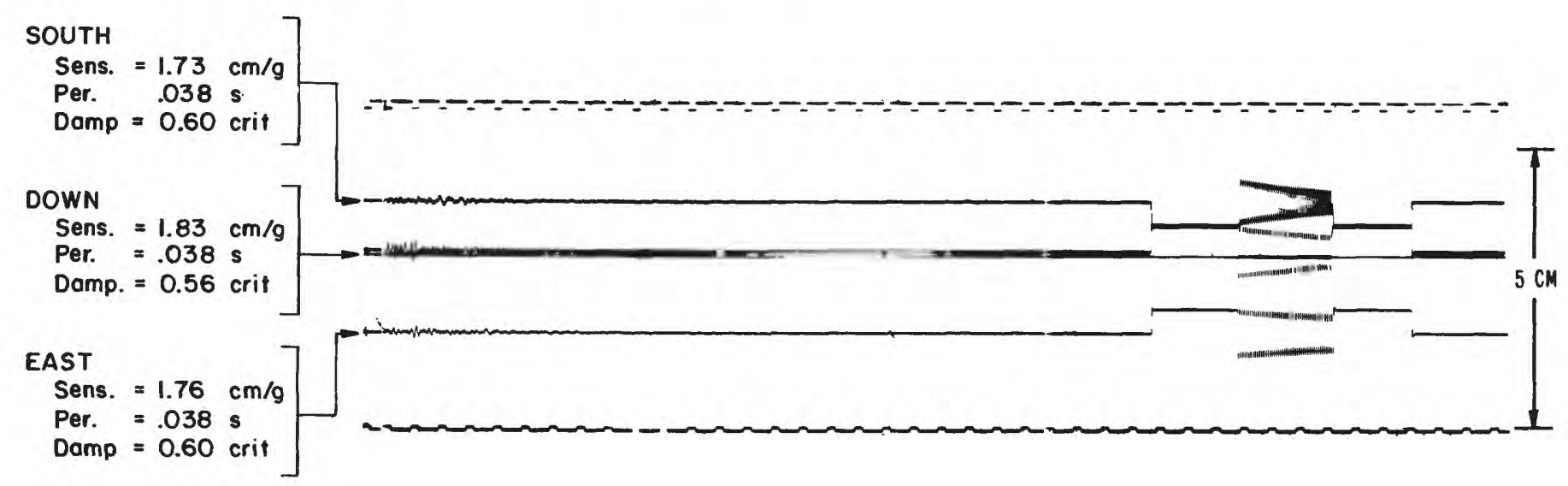




\section{STRONG-MOTION ACCELEROGRAM OF FEBRUARY} 18 AFTERSHOCK

Several aftershocks have been recorded on the accelerographs located at Zacapa, the Observatorio Nacional, and at the IBM building stations. These aftershocks have a Richter magnitude less than 4.0 and are not considered significant. An aftershock was recorded at the IBM building on February 18, 1976 , at $03: 59$ local time. The accelerogram in figure 20 shows a vertical motion of approximately $0.1 \mathrm{~g}$ during the first second.

\section{SAN SALVADOR ACCELEROGRAPH OF MAIN EVENT}

The Observatorio de San Salvador reported that an AR-240 located in San Salvador at the Biblioteca station was triggered by the Guatemala earthquake. The readings obtained from the accelerograms were $0.066 g$ on the north component; $0.25 g$ on the vertical and $0.053 \mathrm{~g}$ on the east component (M. Martinez, oral commun., 1976). The Modified Mercalli intensity rating in San Salvador was V (M. Martinez, oral commun., 1976). 
THE GUATEMALAN EARTHQUAKE OF FEBRUARY 4, 1976, A PRELIMINARY REPORT

\title{
AFTERSHOCKS FROM LOCAL DATA
}

\author{
By Charley J. Langer, Jean P. Whitcomb, and Arturo Aburto Q.
}

\section{INTRODUCTION}

Aftershocks of the main event were monitored in two phases by single-component portable seismographs from February 9 to February 27. This study represents a combined effort by the U.S. Geological Survey and the Nicaraguan Instituto de Investigaciones Sismicas. Rapid deployment of portable instrumentation around the Motagua fault zone provides a data base for the first detailed aftershock investigation of a major earthquake (magnitude greater than 7.5) in Central America. Tectonic and seismic aspects of the main event and large aftershocks are discussed in other sections of the report (Spence and others, Person and others). The topic addressed here is hypocentral locations of a representative sample of locally recorded aftershocks and their relationship to primary and secondary faulting.

\section{INSTRUMENTATION AND FIELD PROCEDURE}

Aftershocks were recorded by portable, smokedpaper seismographs, each consisting of a vertical transducer, a high-gain amplifier, and a crystalcontrolled clock. The seismograph recorded at a speed of $60 \mathrm{~mm} / \mathrm{min}$, and the trace separation was $1 \mathrm{~mm}$, which allowed 48 hours of continuous operation. Precise time corrections were determined with an oscilloscope by comparing WWV radio time with recorder clock times during record changes. Clock drift did not exceed $20 \mathrm{~ms}$ /day. Seismograph magnifications generally ranged between 50,000 and 100 ,000 at $10 \mathrm{~Hz}$. Amplifier gains were limited by the background noise at the sites, most of which were on unconsolidated soils and close to cultural noise sources. Because of the intense aftershock activity at many of the station locations, the peak-to-peak deffection of the recorder pen was limited to $10 \mathrm{~mm}$.

A two-phase aftershock recording program was required because of the great length of fault rupture (more than $240 \mathrm{~km}$ ), constraints imposed by the available logistical support, and the limited amount of seismograph equipment available. The phase I, or western, network (table 5) was installed on February 9 and 10 and extended approximately 95 $\mathrm{km}$ east-west between Sanarate and Chichicastenango. Another portable seismograph was installed in Guatemala City after the main event by personnel at the Observatorio Nacional. This network surrounded the western end of the Motagua fault zone and also encompassed many of the northeast-trending secondary faults in the vicinity of Guatemala City, Chimaltenango, and Tecpan. The phase I operation was terminated on February 17 when all seismographs, except those in Guatemala City, were removed.

During phase II, a much broader seismograph network was installed to the east between Guatemala City and Puerto Barrios (table 5). It covered about $225 \mathrm{~km}$ of the central and eastern segments of the Motagua fault and adjacent regions. On February 18, 19, and 20, seismographs were located at eight sites (table 5). The Puerto Barrios station was relocated at a site near La Piña on February 21 because of the high cultural background noise at Puerto Barrios. Phase II was completed on February 27 when all the instruments were retrieved.

\section{DATA AND ANALYSIS}

Several thousand aftershocks were recorded during the field investigation (fig. 21). The amount of seismic activity was greatest at the western end, near Tecpan and Chimaltenango, and did not noticeably diminish during the 8-day monitoring period of the western network. The unusually high level of observed seismicity in this area is not merely a function of station location or of time, that is, early in the aftershock sequence; the Tecpan-Chimaltenango region is unique to the total aftershock zone in terms of level of seismicity.

Arrival times were determined by using a lowpower magnifier and were corrected for variations in distance between minute marks. S-phases were easily identifiable in many cases, often at two or 
TABLE 5.-List of seismograph stations occupied during this study

\begin{tabular}{|c|c|c|c|c|c|}
\hline Name & Symbol & $\begin{array}{l}\text { Lati- } \\
\text { tude } \\
\left({ }^{\circ} \mathrm{N} .\right)\end{array}$ & $\begin{array}{c}\text { Longi- } \\
\text { tude } \\
\left({ }^{\circ} \mathrm{W} .\right)\end{array}$ & $\begin{array}{c}\text { Eleva- } \\
\text { tion } \\
\text { (metres) }\end{array}$ & $\begin{array}{l}\text { Period of } \\
\text { operation }\end{array}$ \\
\hline \multicolumn{6}{|c|}{ Western network } \\
\hline Chichicastenango _...-. & $\mathrm{CCO}$ & 14.950 & 91.110 & 1,990 & Feb. 9-Feb. 17 \\
\hline Tecpan _... & TEC & 14.766 & 90.996 & 2,320 & Feb. 9-Feb. 17 \\
\hline Joyabaj _. & JOY & 14.990 & 90.804 & 1,400 & Feb. 9-Feb. 17 \\
\hline Chimaltenango & CHM & 14.635 & 90.818 & 1,760 & Feb. 9-Feb. 17 \\
\hline El Chol & ELC & 14.958 & 90.487 & 995 & Feb. 9-Feb. 17 \\
\hline Guatemala City _.... & GCG & 14.586 & 90.533 & 1,497 & Feb. 9-present \\
\hline Palencia _- & PAL & 14.664 & 90.361 & 1,310 & Feb. 10-Feb. 17 \\
\hline Sanarate & SAN & 14.784 & 90.196 & 770 & Feb. 10-Feb. 17 \\
\hline \multicolumn{6}{|c|}{ Eastern network } \\
\hline Guatemala City _._._. & GCG & 14.586 & 90.533 & 1,497 & Feb. 6-present \\
\hline San Jeronimo & SJE & 15.065 & 90.247 & 1,005 & Feb. 18-Feb. 27 \\
\hline Jalapa & JAP & 14.638 & 90.003 & $\mathbf{1}, 370$ & Feb. 18-Feb. 27 \\
\hline Teleman _... & TEL & 15.339 & 89.744 & 65 & Feb. 19-Feb. 27 \\
\hline Chiquimula & CML & 14.801 & 89.533 & 360 & Feb. 18-Feb. 27 \\
\hline Quiriguá _.-_. & ARC & 15.273 & 89.039 & 70 & Feb. 18-Feb. 27 \\
\hline La Esmeralda & RIO & 15.656 & 88.994 & 10 & Feb. 20-Feb. 27 \\
\hline Vitalis & VIT & 15.312 & 88.806 & 120 & Feb. 18-Feb. 27 \\
\hline La Piña & FFF & 15.600 & 88.608 & 40 & Feb. 23-Feb. 27 \\
\hline Puerto Barrios _.---_- & PTO & 15.712 & 88.583 & 40 & Feb. 20-Feb. 22 \\
\hline
\end{tabular}

more stations for the same earthquake. Accuracy of most P-wave times is thought to be within \pm 0.1 $\mathrm{S}$; the selected $\mathrm{S}$-wave readings are believed accurate to $\pm 0.20 \mathrm{~s}$.

Seventy-eight hypocenters (table 6), most of which lie inside or very near to the margins of the temporary seismic networks, were determined by the HYPO71 computer program (Lee and Lahr, 1975). A measure of their solution quality is denoted by the symbol SQ and ranges between $B$ (good) and D (poor). This SQ rating is dependent upon the number and accuracy of data, station distribution, and crustal velocities. All D-quality solutions are a few kilometres outside the network; otherwise they would be rated as B or C.

The average root-mean-square (RMS) errors of the travel-time residuals are $0.17 \mathrm{~s}$, which implies that the random errors in reading the $\mathrm{P}$ - and $\mathrm{S}-$ arrivals account for most of the RMS errors. An average of the standard errors indicates hypocentral accuracies of about $\pm 1.3 \mathrm{~km}$ in the horizontal plane and approximately $\pm 2 \mathrm{~km}$ in the vertical plane. Although the standard errors may not represent actual error limits, particularly for hypocenters outside the seismograph net, S-phase data mitigate the possibility of gross mislocations. Any systematic location error or bias is most likely caused by the six-layer Managua velocity model of Brown, Ward, and Plafker (1973) used in the HYPO71 program. This model was employed in this study because of the absence of velocity data for interior Guatemala. Although the model is an assumed velocity structure for the Managua area, it is representative of volcanic terrane and therefore may be generally appli- cable to the Motagua fault zone west of long $90.5^{\circ}$ W. To the east, where crystalline and marine sedimentary rocks are predominant (Bonis and others, 1970 ), increased velocities would be expected in the upper layers. The Managua model, however, is considered adequate for obtaining preliminary locations.

Because the peak-to-peak signal amplitudes were electronically clipped, local magnitudes, $\mathrm{M}_{\mathrm{L}}$, are estimated from the aftershock coda lengths (Lee and others, 1972). The lower magnitude threshold for hypocentral determinations using either the western or eastern network data is about 2.2. None of the larger aftershocks reported by Person, Spence, and Dewey (this report) occurred within a temporary seismograph net. The largest located event (magnitude 3.8) is approximately one order of magnitude below the limit for teleseismically locatable earthquakes in Central America.

\section{RESULTS AND DISCUSSION}

Aftershock epicenters are distributed along the Motagua Valley from the lowlands near the Gulf of Honduras westward to the Guatemalan highlands northeast of Lake Atitlán, a distance of some 300 $\mathrm{km}$. A large number of located events occurred on secondary faults south of the Motagua fault and west of long $90.3^{\circ} \mathrm{W}$. (fig. 22). Focal depths range from near surface to about $14 \mathrm{~km}$. In particular, we note the following aspects:

1. The eastern terminus of the causal fault rupture is most likely defined by the cluster of 12 epicenters southeast of Puerto Barrios. The gen- 


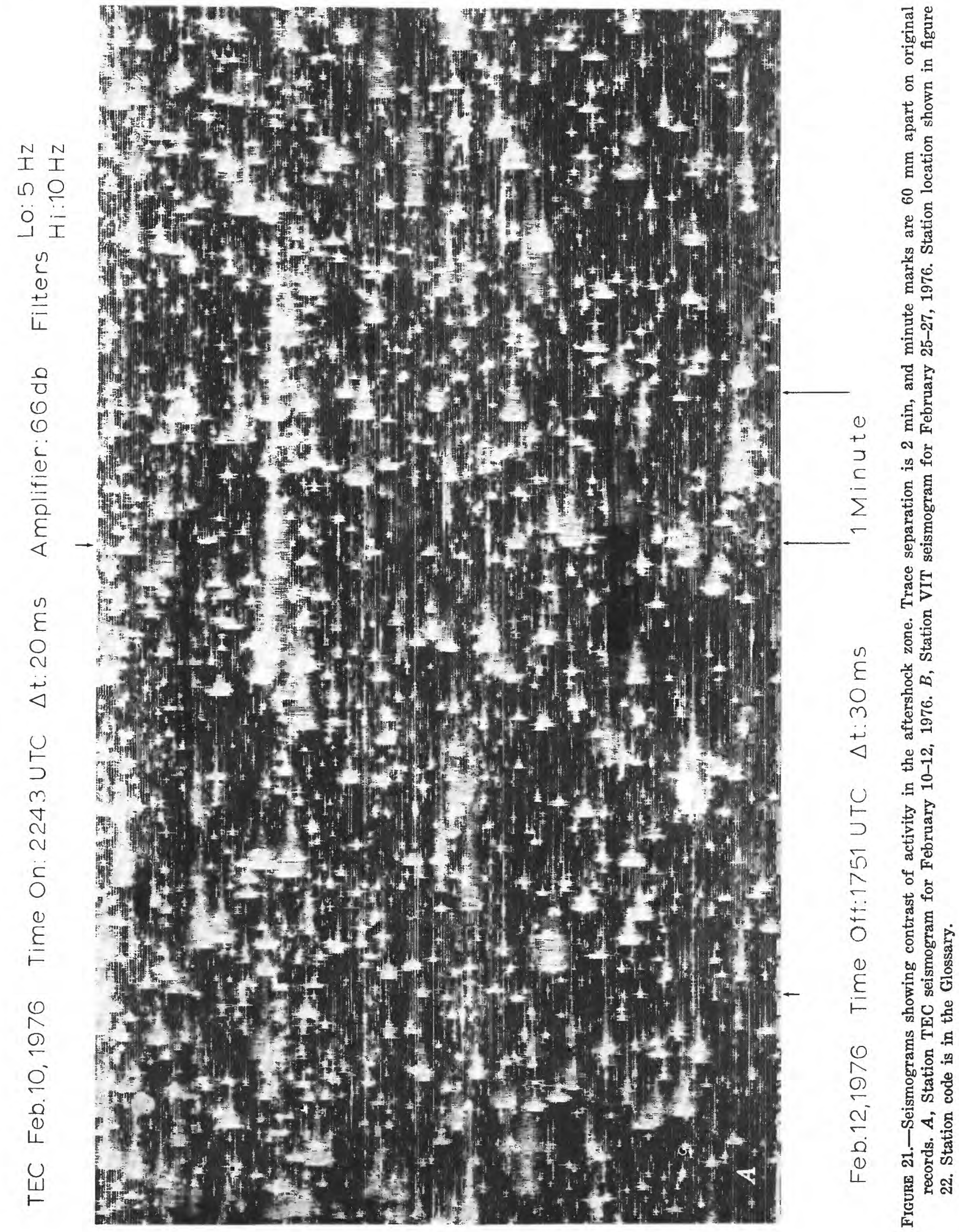




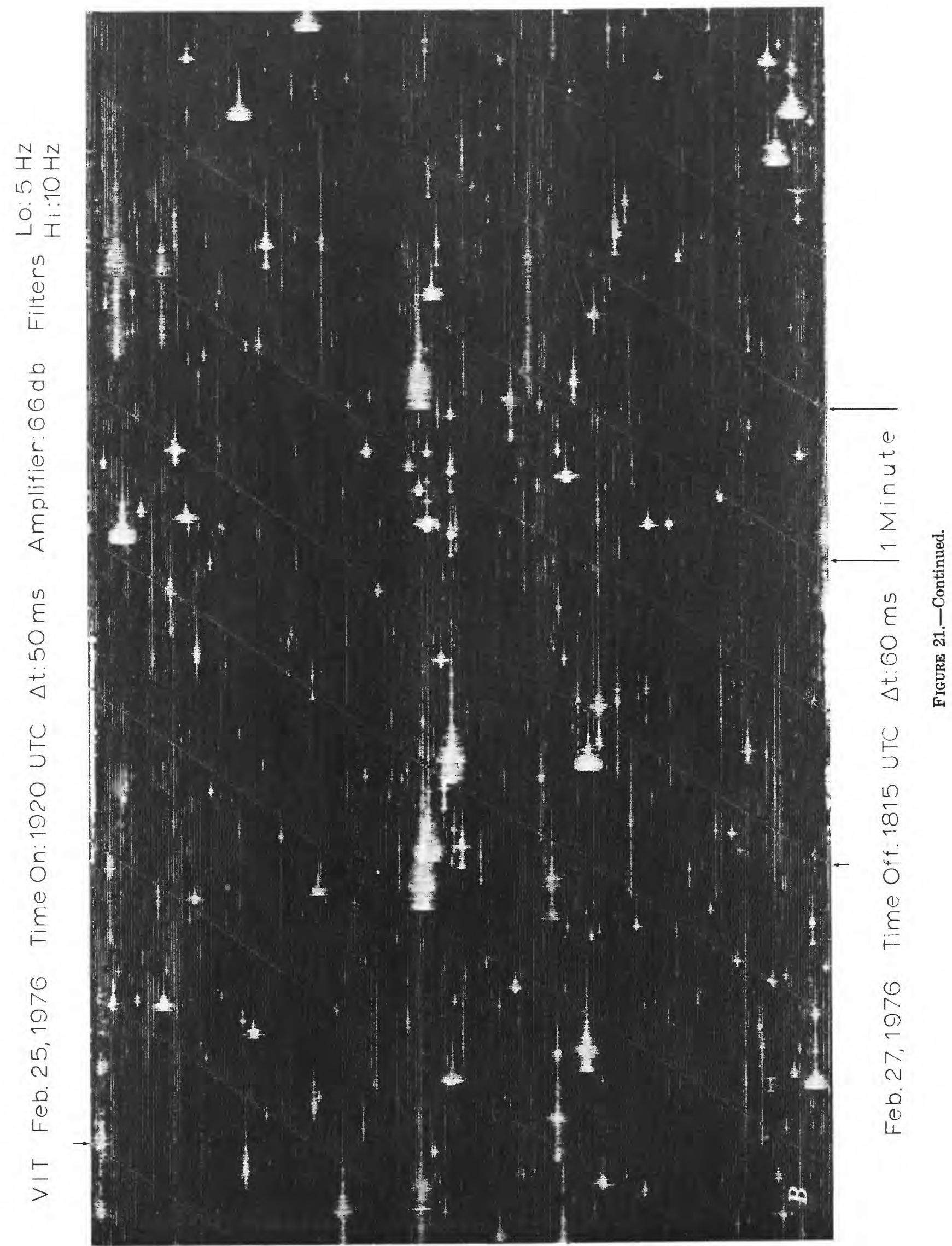


TABLE 6.-Aftershocks of the main event located by temporary seismograph network

$\left[{ }^{1}\right.$ No. sta.--refers to the number of stations used to obtain hypocentral solutions; , ${ }^{2}$ MIN--distance to the closest seismograph station; ${ }^{3}$ RMS--root mean square errors of travel time residuals; ${ }^{4}$ Standard errors--refers to the indices of precision relating to the values and distribution of the unknown errors in the hypocentral solution where DLAT = error in latitude, DLON = error in longitude, and $\mathrm{DZ}=$ error in depth; ${ }^{5} \mathrm{SQ}--\mathrm{a}$ measure that is intended to indicate the general reliability of the hypocentral solution where $A=$ excellent epicenter, good focal depth; $B=$ good epicenter, fair focal depth; $\mathrm{C}=$ fair epicenter, poor focal depth; $\mathrm{D}=$ poor epicenter, poor focal depth; ${ }^{6} M_{L}--$ local magnitude of shock.]

\begin{tabular}{|c|c|c|c|c|c|c|c|c|c|c|c|c|c|}
\hline \multicolumn{14}{|c|}{ Western network } \\
\hline $\begin{array}{c}\text { Date } \\
\text { (Feb. 1976) }\end{array}$ & $\begin{array}{r}\text { Ori } \\
(\mathrm{U}\end{array}$ & $\begin{array}{l}\text { gin } \\
\text { TC) }\end{array}$ & $\begin{array}{l}\text { Lat. N } \\
\text { (deg) }\end{array}$ & $\begin{array}{l}\text { Long. W } \\
\text { (deg) }\end{array}$ & $\begin{array}{r}\text { Depth } \\
(\mathrm{km})\end{array}$ & $\begin{array}{l}\text { No. }{ }^{1} \\
\text { sta. }\end{array}$ & $\begin{array}{l}\mathrm{DMIN}^{2} \\
(\mathrm{~km})\end{array}$ & $\begin{array}{l}\mathrm{RMS}^{3} \\
(\mathrm{sec})\end{array}$ & $\begin{array}{l}\text { Stand } \\
\text { DLAT } \\
(\mathrm{km})\end{array}$ & $\begin{array}{c}\text { lard er } \\
\text { DLON } \\
(\mathrm{km})\end{array}$ & $\begin{array}{c}\text { rrors }^{4} \\
\text { DZ } \\
(\mathrm{km})\end{array}$ & $\mathrm{SQ}^{5}$ & $M_{L}{ }^{6}$ \\
\hline $1 \mathrm{i}$ & 0636 & 48.69 & 14.750 & 91.126 & 9.2 & 8 & 14 & 0.18 & 1.1 & 1.3 & 1.5 & C & 3.2 \\
\hline 11 & 0932 & 20.37 & 14.808 & 90.510 & 10.0 & 7 & 17 & 0.14 & 0.9 & 0.6 & 2.1 & B & 3.1 \\
\hline 11 & 0953 & 02.55 & 14.760 & 90.980 & 7.0 & 7 & 2 & 0.11 & 0.6 & 0.8 & 1.2 & B & 2.9 \\
\hline 11 & 1044 & 34.78 & 14.763 & 91.024 & 10.3 & 7 & 3 & 0.09 & 0.6 & 0.7 & 0.5 & C & 2.8 \\
\hline 11 & 1051 & 03.91 & 14.767 & 90.975 & 4.2 & 7 & 2 & 0.19 & 1.5 & 1.5 & 1.5 & B & 2.9 \\
\hline 11 & 1142 & 03.72 & 14.724 & 90.998 & 4.0 & 8 & 5 & 0.22 & 1.3 & 1.3 & 1.4 & C & 2.9 \\
\hline 11 & 1636 & 23.01 & 14.790 & 90.984 & 4.9 & 7 & 3 & 0.04 & 0.3 & 0.3 & 0.4 & B & 3.0 \\
\hline 11 & 2210 & 58.78 & 14.637 & 90.680 & 4.0 & 10 & 6 & 0.16 & 1.7 & 0.4 & 1.8 & C & 3.3 \\
\hline 11 & 2253 & 51.55 & 14.809 & 90.596 & 2.0 & 7 & 20 & 0.24 & 0.4 & 0.3 & 1.2 & $\mathrm{C}$ & 2.4 \\
\hline 12 & 0039 & 13.82 & 14.759 & 90.501 & 2.0 & 6 & 18 & 0.25 & 0.6 & 0.5 & 1.9 & C & 2.7 \\
\hline 12 & 0144 & 35.11 & 14.861 & 90.343 & 12.2 & 7 & 18 & 0.20 & 1.9 & 1.7 & 2.4 & C & 2.6 \\
\hline 12 & 0215 & 04.82 & 14.694 & 90.468 & 6.0 & 8 & 12 & 0.11 & 0.7 & 0.4 & 2.2 & C & 3.3 \\
\hline 12 & 0333 & 36.40 & 14.855 & 90.710 & 12.0 & 9 & 18 & 0.21 & 0.9 & 0.7 & 1.6 & B & 2.7 \\
\hline 12 & 0408 & 15.10 & 14.745 & 90.499 & 13.0 & 8 & 17 & 0.22 & 0.9 & 0.8 & 2.4 & B & 2.5 \\
\hline 12 & 0439 & 54.52 & 14.636 & 90.668 & 12.1 & 7 & 16 & 0.11 & 1.1 & 0.4 & 1.4 & C & 3.0 \\
\hline 12 & 0545 & 45.58 & 14.827 & 90.513 & 13.0 & 8 & 15 & 0.19 & 0.9 & 0.6 & 1.9 & B & 2.8 \\
\hline 12 & 0702 & 02.43 & 14.859 & 90.340 & 10.5 & 8 & 14 & 0.11 & 0.8 & 0.5 & 1.3 & B & 3.3 \\
\hline 12 & 0743 & 42.34 & 14.800 & 90.544 & 12.3 & 7 & 18 & 0.19 & 1.1 & 1.0 & 2.7 & B & - \\
\hline 12 & 0744 & 35.68 & 14.852 & 90.619 & 12.2 & 9 & 18 & 0.25 & 1.0 & 0.7 & 4.3 & B & 3.0 \\
\hline 12 & 1057 & 35.51 & 14.714 & 90.796 & 11.7 & 8 & 9 & 0.10 & 0.7 & 0.4 & 1.2 & B & 3.2 \\
\hline 12 & 1203 & 33.49 & 14.589 & 90.625 & 13.2 & 7 & 21 & 0.09 & 1.0 & 0.4 & 1.0 & C & 3.2 \\
\hline 12 & 1927 & 36.00 & 14.590 & 91.037 & 10.0 & 8 & 9 & 0.13 & 0.8 & 1.6 & 1.2 & C & 3.4 \\
\hline 12 & 2211 & 59.01 & 14.674 & 90.482 & 12.0 & 7 & 13 & 0.20 & 0.9 & 1.0 & 2.4 & C & 2.4 \\
\hline 12 & 2250 & 34.00 & 14.760 & 90.355 & 5.4 & 7 & 11 & 0.28 & 2.6 & 1.4 & 4.8 & C & 2.9 \\
\hline 13 & 0627 & 42.32 & 14.673 & 90.483 & 10.0 & 7 & 13 & 0.16 & 0.7 & 0.8 & 5.3 & C & 3.1 \\
\hline 13 & 0701 & 32.46 & 14.684 & 90.477 & 11.9 & 8 & 13 & 0.18 & 0.9 & 0.7 & 2.2 & C & 3.2 \\
\hline 13 & 1344 & 01.31 & 14.755 & 90.987 & 5.7 & 8 & 1 & 0.16 & 1.0 & 2.3 & 1.7 & C & 3.2 \\
\hline 13 & 2359 & 50.50 & 14.767 & 91.025 & 1.1 & 8 & 3 & 0.20 & 1.5 & 1.2 & 1.5 & C & 3.3 \\
\hline
\end{tabular}




\begin{tabular}{|c|c|c|c|c|c|c|c|c|c|c|c|c|c|}
\hline \multicolumn{14}{|c|}{ Western network } \\
\hline $\begin{array}{l}\text { Date } \\
\text { (Feb. 1976) }\end{array}$ & Ori & $\begin{array}{l}\text { gin } \\
\text { TC) }\end{array}$ & $\begin{array}{r}\text { Lat. N } \\
\text { (deg) }\end{array}$ & $\begin{array}{l}\text { Long. W } \\
\text { (deg) }\end{array}$ & $\begin{array}{r}\text { Depth } \\
(\mathrm{km})\end{array}$ & $\begin{array}{l}\text { No. }{ }^{1} \\
\text { sta. }\end{array}$ & $\begin{array}{l}\text { DMIN }{ }^{2} \\
(\mathrm{~km})\end{array}$ & $\begin{array}{c}\text { RMS }^{3} \\
(\mathrm{sec})\end{array}$ & $\begin{array}{l}\text { Stand } \\
\text { DLAT } \\
(k m)\end{array}$ & $\begin{array}{c}\text { ard er } \\
\text { DLON } \\
(\mathrm{km})\end{array}$ & $\begin{array}{c}\text { rrors }^{4} \\
\mathrm{DZ} \\
(\mathrm{km})\end{array}$ & $S Q^{5}$ & $\mathrm{M}_{\mathrm{L}}{ }^{5}$ \\
\hline 14 & 0300 & 40978 & 14.858 & 90.636 & 11.7 & 9 & 20 & 0.10 & 0.4 & 0.3 & 1.2 & B & 3.1 \\
\hline 14 & $0 \tilde{15}$ & 59.79 & 14.696 & 90.545 & 10.0 & 8 & 20 & 0.20 & 0.9 & 0.8 & 2.8 & $\mathrm{C}$ & 3.2 \\
\hline 14 & 0424 & 53.89 & 14.831 & 90.319 & 9.0 & 7 & 14 & 0.25 & 1.2 & 1.5 & 3.7 & $\mathrm{C}$ & 2.4 \\
\hline 14 & 0916 & 38.15 & 14.711 & 90.737 & 10.7 & 9 & 12 & 0.17 & 1.0 & 0.7 & 2.1 & B & 3.1 \\
\hline 14 & 1543 & 57.80 & 14.699 & 90.481 & 12.0 & 8 & 13 & 0.19 & 0.6 & 0.5 & 1.5 & $\mathrm{C}$ & 2.7 \\
\hline 14 & 1757 & 33.16 & 14.700 & 90.514 & 12.4 & 8 & 17 & 0.32 & 1.6 & 1.6 & 3.7 & $\mathrm{C}$ & 3.2 \\
\hline 14 & 1842 & 41.94 & 14.754 & 90.312 & 10.0 & 7 & 11 & 0.29 & 0.6 & 0.7 & 2.8 & B & 2.2 \\
\hline 14 & 1912 & 53.22 & 14.643 & 90.950 & 4.0 & 8 & 14 & 0.14 & 1.2 & 0.8 & 0.8 & C & 3.8 \\
\hline 14 & 2036 & 28.16 & 14.815 & 90.583 & 10.6 & 8 & 19 & 0.14 & 0.7 & 0.6 & 1.9 & B & 3.5 \\
\hline 14 & 2044 & 04.68 & 14.743 & 90.377 & 6.0 & 8 & 9 & 0.24 & 0.7 & 0.8 & 3.5 & B & 3.1 \\
\hline 14 & 2122 & 55.03 & 14.740 & 91.007 & 11.4 & 8 & 3 & 0.10 & 1.1 & 1.0 & 0.5 & C & 3.2 \\
\hline 14 & 2219 & 24.40 & 14.746 & 90.355 & 8.0 & 7 & 9 & 0.24 & 0.5 & 0.6 & 1.6 & B & 2.8 \\
\hline 14 & 2318 & 26.40 & 14.741 & 90.323 & 5.0 & 6 & 9 & 0.21 & 1.4 & 0.5 & 2.0 & B & 2.8 \\
\hline 15 & 0034 & 43.75 & 14.776 & 90.965 & 6.2 & 9 & 4 & 0.15 & 0.6 & 0.6 & 1.6 & B & 3.4 \\
\hline 15 & 0436 & 12.15 & 14.808 & 90.551 & 2.5 & 10 & 18 & 0.27 & 0.6 & 0.5 & 1.1 & C & 3.4 \\
\hline 15 & 0650 & 31.18 & 14.728 & 90.359 & 2.5 & 8 & 7 & 0.24 & 0.8 & 0.9 & 2.7 & B & 2.4 \\
\hline 15 & 1053 & 24.11 & 14.720 & 90.748 & 10.0 & 8 & 12 & 0.25 & 0.5 & 0.5 & 3.3 & B & 3.2 \\
\hline 15 & 1308 & 31.57 & 14.782 & 90.980 & 6.4 & 9 & 2 & 0.10 & 0.6 & 0.5 & 0.9 & B & 3.4 \\
\hline 15 & 2019 & 59.93 & 14.792 & 90.982 & 3.8 & 6 & 3 & 0.25 & 2.4 & 2.3 & 4.0 & C & 3.2 \\
\hline 16 & 0758 & 08.62 & 14.848 & 90.678 & 12.2 & 11 & 21 & 0.16 & 0.7 & 0.4 & 1.1 & B & 2.9 \\
\hline 16 & 0911 & 46.82 & 14.750 & 90.998 & 10.0 & 7 & 2 & 0.23 & 1.8 & 1.9 & 1.2 & D & 3.1 \\
\hline 17 & 0345 & 47.31 & 14.708 & 91.008 & 7.8 & 6 & 6 & 0.04 & 0.5 & 0.5 & 0.5 & C & 2.8 \\
\hline 17 & 0527 & 05.94 & 14.723 & 90.801 & 11.8 & 10 & 10 & 0.20 & 0.8 & 0.6 & 2.2 & B & 2.9 \\
\hline 17 & 1549 & 25.34 & 14.791 & 90.974 & 2.4 & 6 & 4 & 0.09 & 1.2 & 0.8 & 1.4 & B & 2.9 \\
\hline 20 & 0321 & 50.53 & 15.152 & 89.228 & 1.3 & 8 & 24 & 0.16 & 0.9 & 0.7 & 1.1 & C & 2.4 \\
\hline 21 & 0205 & 36.04 & 15.052 & 89.452 & 5.9 & 7 & 29 & 0.18 & 1.0 & 1.0 & 4.0 & C & 3.1 \\
\hline 21 & 0752 & 07.81 & 14.991 & 89.627 & 10.4 & 8 & 23 & 0.20 & 0.9 & 0.7 & 2.0 & C & 3.2 \\
\hline 21 & 1303 & 52.99 & 14.971 & 89.676 & 11.2 & 6 & 24 & 0.08 & 0.5 & 0.5 & 1.2 & B & 2.9 \\
\hline 22 & 0500 & 33.55 & 15.671 & 88.445 & 10.0 & 5 & 16 & 0.16 & 0.8 & 2.3 & 1.6 & C & 2.6 \\
\hline 22 & 0642 & 40.71 & 15.526 & 88.520 & 8.5 & 6 & 22 & 0.07 & 0.7 & 1.5 & 5.5 & D & 2.9 \\
\hline 22 & 1209 & 58.28 & 15.275 & 89.007 & 10.0 & 6 & 3 & 0.16 & 2.8 & 1.0 & 1.8 & D & 3.7 \\
\hline 22 & 2138 & 32.95 & 15.217 & 89.003 & 14.0 & 7 & 7 & 0.16 & 1.5 & 0.8 & 0.9 & C & 3.8 \\
\hline 23 & 0503 & 36.68 & 15.314 & 88.906 & 8.9 & 6 & 11 & 0.16 & 1.3 & 0.9 & 1.6 & C & 3.2 \\
\hline 24 & 0417 & 00.95 & 15.670 & 88.437 & 10.0 & 5 & 20 & 0.21 & 0.6 & 1.4 & 1.1 & C & 2.7 \\
\hline 24 & 07.57 & 18.11 & 15.556 & 88.519 & 5.1 & 6 & 11 & 0.10 & 2.2 & 2.1 & 2.8 & n & 2.2 \\
\hline
\end{tabular}


TABLE 6.-Aftershocks of the main event located by temporary seismograph network-Continued

\begin{tabular}{|c|c|c|c|c|c|c|c|c|c|c|c|c|c|}
\hline \multicolumn{14}{|c|}{ Eastern network } \\
\hline $\begin{array}{c}\text { Date } \\
\text { (Feb. 1976) } \\
\end{array}$ & $\begin{array}{r}\text { Ori } \\
(\mathrm{U}\end{array}$ & $\begin{array}{l}\text { gin } \\
\text { TC) }\end{array}$ & $\begin{array}{c}\text { Lat. N } \\
\text { (deg) }\end{array}$ & $\begin{array}{l}\text { Long. W } \\
\text { (deg) }\end{array}$ & $\begin{array}{c}\text { Depth } \\
(\mathrm{km})\end{array}$ & $\begin{array}{l}\text { No. }{ }^{1} \\
\text { sta. }\end{array}$ & $\begin{array}{l}\text { DMIN }^{2} \\
(\mathrm{~km})\end{array}$ & $\begin{array}{c}\mathrm{RMS}^{3} \\
(\mathrm{sec})\end{array}$ & $\begin{array}{l}\text { Stand } \\
\text { DLAT } \\
(\mathrm{km})\end{array}$ & $\begin{array}{c}\text { ard er } \\
\text { DLON } \\
(\mathrm{km})\end{array}$ & $\begin{array}{c}\text { rrors }^{4} \\
\mathrm{DZ} \\
(\mathrm{km})\end{array}$ & $S Q^{5}$ & $\mathrm{M}_{\mathrm{L}}{ }^{6}$ \\
\hline 24 & 0807 & 06.51 & 14.983 & 89.635 & 8.5 & 8 & 23 & 0.11 & 0.3 & 0.4 & 1.6 & B & 2.7 \\
\hline 24 & 0821 & 49.24 & 15.660 & 88.438 & 1.6 & 6 & 19 & 0.13 & 0.6 & 0.5 & 0.5 & C & 3.2 \\
\hline 24 & 1316 & 05.14 & 15.485 & 88.601 & 10.0 & 5 & 13 & 0.20 & 0.6 & 0.9 & 2.6 & $\mathrm{C}$ & 2.5 \\
\hline 24 & 1337 & 59.96 & 15.496 & 88.599 & 12.4 & 6 & 12 & 0.27 & 2.6 & 2.5 & 4.2 & D & 3.0 \\
\hline 25 & 0128 & 48.30 & 14.977 & 89.674 & 5.9 & 7 & 25 & 0.13 & 0.3 & 0.4 & 1.2 & B & 3.3 \\
\hline 26 & 0033 & 22.94 & 14.964 & 89.690 & 7.6 & 8 & 25 & 0.05 & 0.2 & 0.2 & 1.0 & B & 2.7 \\
\hline 26 & 0510 & 13.27 & 15.617 & 88.437 & 7.0 & 5 & 18 & 0.19 & 1.0 & 0.8 & 1.1 & C & 2.4 \\
\hline 26 & 1120 & 06.00 & 14.841 & 89.641 & 8.6 & 7 & 13 & 0.14 & 1.1 & 0.6 & 2.0 & B & 2.9 \\
\hline 26 & 1903 & 20.29 & 15.561 & 88.515 & 8.0 & 6 & 11 & 0.21 & 0.5 & 1.1 & 2.1 & c & 2.3 \\
\hline 26 & 2216 & 11.70 & 14.972 & 89.612 & 8.0 & 8 & 21 & 0.17 & 0.5 & 0.7 & 2.0 & $\mathrm{C}$ & 2.8 \\
\hline 27 & 0120 & 58.22 & 15.580 & 88.451 & 9.0 & 5 & 17 & 0.05 & 0.9 & 1.0 & 1.0 & C & 3.1 \\
\hline 27 & 0344 & 29.49 & 14.972 & 89.662 & 10.0 & 8 & 23 & 0.28 & 0.5 & 0.7 & 1.8 & C & 2.7 \\
\hline 27 & 0458 & 00.86 & 15.537 & 88.565 & 2.8 & 5 & 8 & 0.14 & 0.4 & 3.3 & 2.8 & $\mathrm{D}$ & 2.5 \\
\hline 27 & 1200 & 38.49 & 15.602 & 88.621 & 5.7 & 7 & 1 & 0.20 & 2.0 & 4.0 & 2.8 & C & 2.4 \\
\hline
\end{tabular}

eral trend of the southern group of eight aftershocks is in line with the inferred extension of the Motagua fault (Plafker and others, this report), whereas the four epicenters slightly to the north may be associated with induced movement at the eastern end of the San Agustín fault.

2. Epicenters associated with the western end of the Motagua fault do not extend beyond the mapped fault breakage. Consequently, with the data at hand, the aftershock pattern does not suggest a more precise limit to the primary fault rupture than the obvious diminution of seismicity west of long $90.45^{\circ} \mathrm{W}$. Also, there are no located aftershocks that appear to be related to induced movement on the western segment of the San Agustín fault.

3. The distribution of energy release along the Motagua fault proper is roughly uniform, with exception of the concentration of activity west of Zacapa. The group of seven epicenters between long $89.6^{\circ} \mathrm{W}$. and $89.7^{\circ} \mathrm{W}$. may be a result of fracturing east of where the Motagua fault bends from a general east-west direction to a northeasterly direction. Three northeast-trending secondary faults (not shown in fig. 22), which cut Paleozoic metamorphic rocks, are mapped in this area (Bonis and others, 1970).

4. The majority of aftershocks located west of long $90.3^{\circ} \mathrm{W}$. are directly associated with secondary faulting. Four groups are considered to be of principal interest:

a. Tecpan (long $91^{\circ} \mathrm{W}$., lat $14.75^{\circ} \mathrm{N}$.). The high level of activity observed at the Tecpan seismic station (fig. 21) is reflected by the dense cluster of epicenters located in this area. Plafker, Bonilla, and Bonis (this report) have defined a lineament that projects through Tecpan and the center of the northeasterly trending concentration of aftershocks. Therefore, on the basis of the epicentral locations, the lineament can be interpreted as a northeast-striking fault.

b. Chimaltenango. Four epicenters occurring in the vicinity of a northeast-striking lineament that runs through Chimaltenango lend support to the existence of a secondary fault.

c. Guatemala City region. These aftershocks are very likely associated with faults 


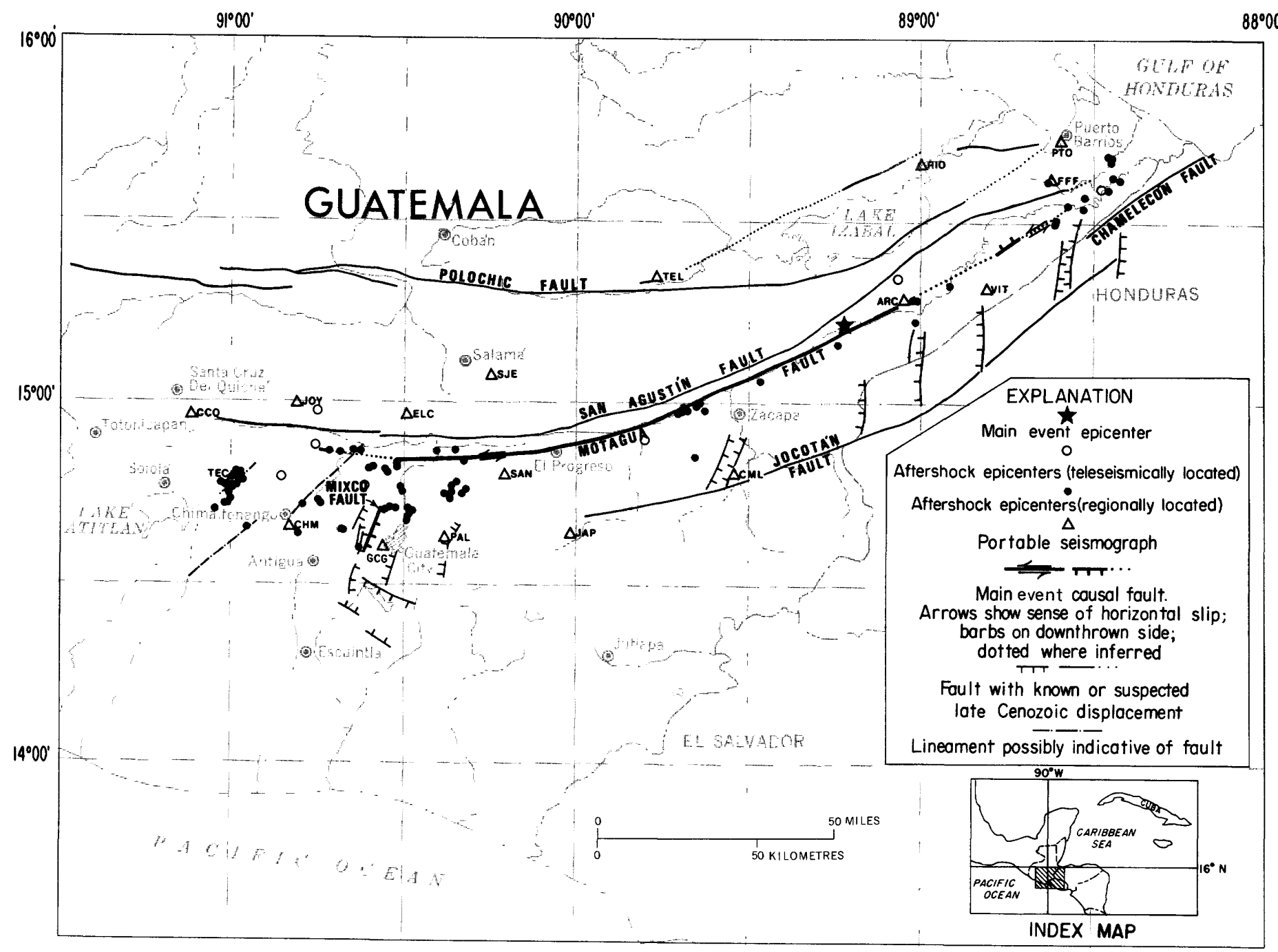

FIGURE 22.-Aftershock epicenters and portable seismograph locations (geology from Plafker and others, this report). See table 5 for station names and their geographical locations and table 6 for aftershock-location parameters. Station code is in the Glossary. (Base map modified from Guatemala, Instituto Geográfico Nacional, 1974, 1:500,000.)

forming the Guatemala City graben. The Mixco fault, west of the city, ruptured the ground surface. Some epicenters appear to correlate with the Mixco fault and also with the northerly extension of the mapped fault bounding Guatemala City on the southeast.

d. Agua Caliente (long $90.35^{\circ}$ W., lat $14.75^{\circ}$ N). A group of epicenters $15 \mathrm{~km}$ north of Palencia (station PAL) surround the Agua Caliente Bridge site. Secondary faulting, although not mapped at this locale, is certainly indicated by the aftershock cluster and may have contributed, in part, to the collapse of the bridge.

5. The preponderance of aftershocks lying off the Motagua fault west of long $90.3^{\circ} \mathrm{W}$. suggests that induced motion along secondary faults is rare east of long $90.3^{\circ} \mathrm{W}$.

6. There is an apparent southerly bias of epicentral locations along the Motagua fault proper. The spatial distribution of aftershocks thought to be associated with the primary fault indicates a systematic offset of 2 to 3 $\mathrm{km}$. This offset would suggest that (1) the Motagua fault is dipping steeply to the south in accordance with the main-event focal mechanism of Dewey and Julian (this report) or (2) there is a large contrast in seismic velocities across the fault similar to that observed by Eaton, O' Neill, and Murdock (1970) on the San Andreas rift zone near Parkfield, California. 
THE GUATEMALAN EARTHQUAKE OF FEBRUARY 4, 1976, A PRELIMINARY REPORT

\title{
GEOLOGIC EFFECTS
}

\author{
By George Plafker, Manuel G. Bonilla, and Samuel B. Bonis ${ }^{1}$
}

\section{INTRODUCTION}

This report is based on preliminary field studies of the geologic effects of the earthquake made during an 11-day period from February 5 to 16, 1976. During this period, we examined the main and secondary faults on the ground, using vehicles and helicopters for logistic support. In addition, several reconnaissance flights were made with fixed-wing aircraft over most of the area that was strongly affected by the earthquake to identify and map landslides, liquefaction phenomena, and damage to communities near the surface faults. Some of our interpretations may be modified by the more detailed field investigations that were being conducted by the U.S. Geological Survey and other organizations at the time this paper was written (MarchApril).

\section{THE MAIN FAULT}

The main fault along which the destructive main event $\left(M_{s}=7.5\right)$ occurred was identified for $240 \mathrm{~km}$ in the Motagua Valley and the mountainous area west of the valley ${ }^{2}$ (fig. 23). This fault is of special interest because it is the most extensive surface rupture in the Northern Hemisphere since the 1906 San Francisco earthquake. Identification of this fault permits evaluation of damage relative to the earthquake source and provides critical new information on the present mode of deformation to a major tectonic belt of Central America. The eastern part of this major fault, within the Motagua Valley, has been named the Motagua fault (Dengo and Bohnenberger, 1969 ; Instituto Geográfico Nacional, Chiquimula 1:250,000 sheet, 1969), and this name is herein applied to all the fault that slipped during the earthquake.

Ground breakage was observed in a discontinuous line extending $240 \mathrm{~km}$ from near Quebradas in the lower Motagua Valley on the east to about $10 \mathrm{~km}$ east of Patzaj on the west. ${ }^{2}$ At the closest point, the fault is $25 \mathrm{~km}$ north of the center of Guatemala City. The fault could not be identified farther to the west because the area is characterized by young volcanic deposits and rugged terrane in which numerous earthquake-triggered slope failures effectively mask the fault-related surface fractures. At the eastern end, the fault trace is obscured in the lower Motagua Valley by swamps and dense tropical vegetation. However, the occurrence of aftershocks southeast of Puerto Barrios (Langer and others, this report) near the eastern coast suggests that the faulting probably extends at least that far. If so, the main break is on the order of 300 $\mathrm{km}$ long ${ }^{2}$. Some of the characteristics of the faulting at localities where it was studied on the ground are given in table 7.

The fault trace is a well-defined linear zone with a gradual change in average strike from N. $65^{\circ} \mathrm{E}$. at the eastern end to $\mathrm{N} .80^{\circ} \mathrm{W}$. at the western end. It consists of right-stepping en echelon fractures and connecting low compressional ridges that locally form the "mole tracks" that are characteristic of strike-slip faults (figs. 24-28). Individual fractures within the zone may be as much as $10 \mathrm{~m}$ long; most are tightly closed, but some have spread as much as $10 \mathrm{~cm}$. The fractures are oriented at angles of as much as $35^{\circ}$ to the fault trace and have the northeasterly azimuths that are to be expected for sinistral slip. The width of the fracture zone is mostly 1 to $3 \mathrm{~m}$, with a maximum observed width of about $9 \mathrm{~m}$. At one locality near El Progreso, where the fault surface is exposed in a highway cut, the zone of slip is 1 to $3 \mathrm{~m}$ wide, and the dip is essentially vertical.

Displacement across the fault in most places is almost entirely horizontal and sinistral. The strike-

\footnotetext{
1 Instituto Geográfico Nacional de Guatemala.
${ }^{2}$ Later, more detailed studies indicate that the length of surface faulting is $230 \mathrm{~km}$ and that the main break from relocated epicenter data is $270 \mathrm{~km}$.
} 


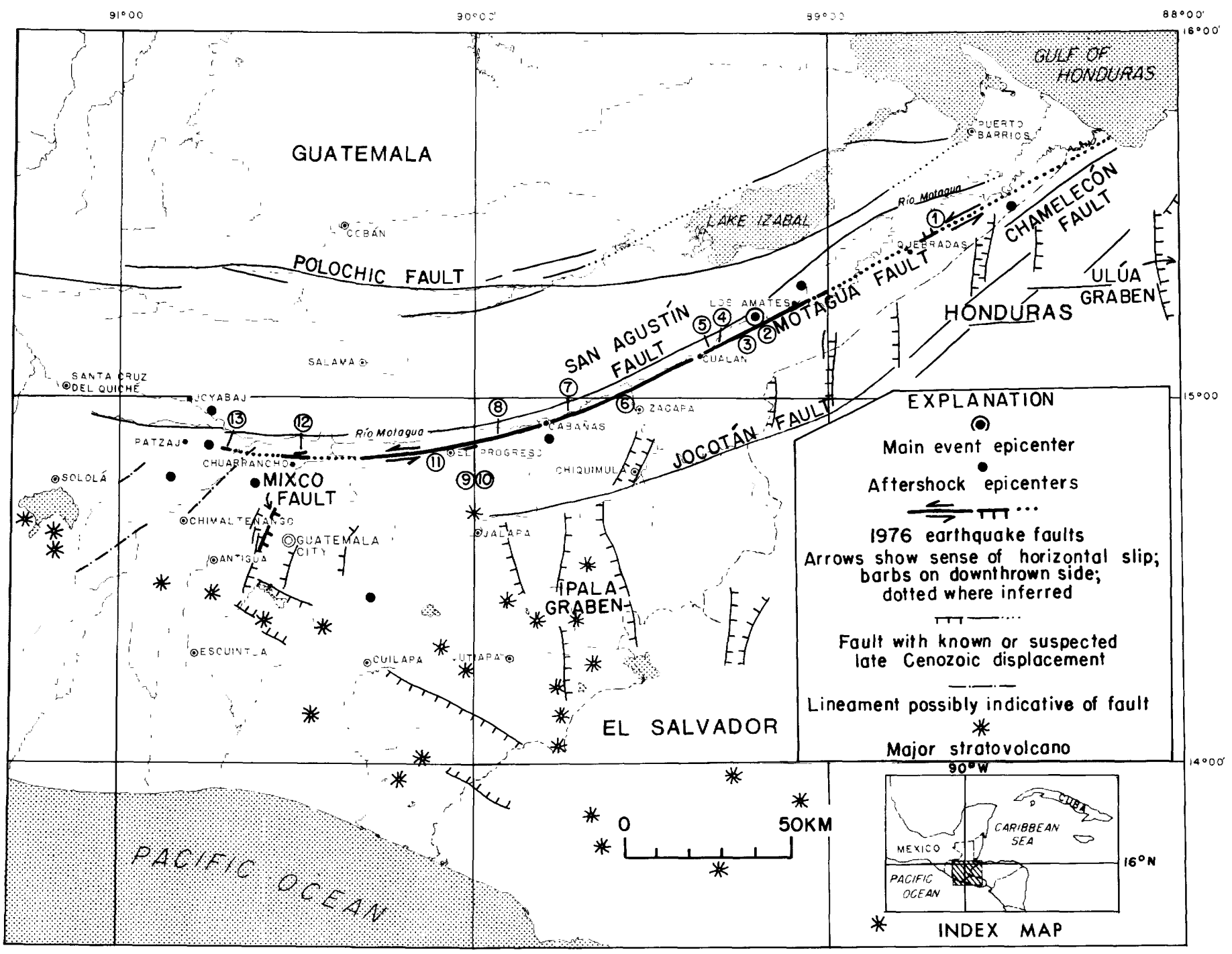

FIGURE 23.-Relationship of the Motagua and Mixco faults to the main-event epicenter, the epicenters of large aftershocks, and major structural and volcanic features in northern Central America. Numerals along the Motagua fault refer to localities listed in table 7. Epicenters are from data of the NEIS and Person, Spence, and Dewey (this report); faults and volcanoes are modified from Dengo (1968) and Bonis, Bohnenberger, and Dengo (1970).

slip component of displacement appears to increase irregularly from about $73 \mathrm{~cm}$ near near Quebradas at the eastern end of the exposed trace to a measured maximum on a single trace of $142 \mathrm{~cm}$ in the area due north of Guatemala City. ${ }^{3}$ At the extreme western end of the observed trace, a single measurement suggests that displacement there may decrease to $68 \mathrm{~cm}$. However, since this locality is in an area of large-scale gravity sliding, the reliability of the measurement is uncertain. The vertical offsets that we observed along the fault are generally minor (less than 30 percent of the horizontal component) and down to either the north or the south. An exception is the 10-km-long segment near Quebradas at the eastern end of the observed surface

${ }^{3}$ Later studies indicate that maximum sinistral displacement is as much as $325 \mathrm{~cm}$ in the area between El Progreso and Chuarrancho. trace where the vertical displacement is consistently down to the north and locally as much as $\mathbf{5 0}$ percent of the sinistral component.

Subsidiary faults and splays appear to be relatively scarce along the Motagua fault; the only two occurrences noted in our preliminary reconnaissance are near El Progreso and Chuarrancho. Just northeast of El Progreso, a subsidiary fault about 1 $\mathrm{km}$ long with $20-\mathrm{cm}$ sinistral displacement is oriented roughly parallel to, and $400 \mathrm{~m}$ south of, the main fault trace. Near Chuarrancho (north of Guatemala City), a prominent surface break splays off the main trace in a northeasterly direction at an angle of about $15^{\circ}$. This splay has a sinistral offset of $28 \mathrm{~cm}$ and was estimated from the air to be about $250 \mathrm{~m}$ long. 
TABLE 7.-Characteristics of earthquake fractures along the Motagua fault

[Measured aggregate displacement: , estimate; (?), measured displacement probably not true value; >, measured displacement probably minimum value; $S$, sinistral or left-lateral; $V$, vertical. Leaders indicate no data. Observations by George Plafker, S. B. Bonis, and M. G. Bonilla, February 6-13, 1976]

\begin{tabular}{|c|c|c|c|c|c|c|c|}
\hline $\begin{array}{l}\text { Station } \\
\text { (fig. 23) }\end{array}$ & $\begin{array}{l}\text { Trend of } \\
\text { fault zone }\end{array}$ & $\begin{array}{l}\text { Approx. width } \\
\text { of fault } \\
\text { zone }(\mathrm{m})\end{array}$ & $\begin{array}{l}\text { Average trend } \\
\text { of fractures }\end{array}$ & $\begin{array}{l}\text { Measured } \\
\text { displacement } \\
(\mathrm{cm})\end{array}$ & $\begin{array}{c}\text { Sense of } \\
\text { displacement }\end{array}$ & Ground surfac & Remarks \\
\hline 1 & $\mathrm{~N} 70 \mathrm{E}$ & 1.5 & $-\ldots-1$ & 72 & $\begin{array}{l}S \\
V\end{array}$ & Pasture & $\begin{array}{l}\text { Down-to-north. North- } \\
\text { facing scarp as } \\
\text { much as } 5 \mathrm{~m} \text { high } \\
\text { along part of fault. } \\
\text { See fig. } 27 \text {. }\end{array}$ \\
\hline 2 & N65E & 3 & N32E & $>33$ & S & Dirt road & $\begin{array}{l}\text { Minimum displacement, } \\
\text { measured across the } \\
\text { largest fracture } \\
\text { in a zone contain- } \\
\text { ing } 7 \text { fractures. }\end{array}$ \\
\hline 3 & $\cdots$ & $-\cdots-$ & - & (?) 107 & S & $\begin{array}{l}\text { Railroad } \\
\text { embankment }\end{array}$ & $\begin{array}{l}\text { Offset railroad tracks } \\
\text { Unreliable measure- } \\
\text { ment due to gentle } \\
\text { curve in tracks. }\end{array}$ \\
\hline 4 & N65E & 1 & N50E & 93 & $\mathrm{~s}$ & $\begin{array}{l}\text { Concrete- } \\
\text { lined canal }\end{array}$ & $\begin{array}{l}\text { Good displacement } \\
\text { measurement. }\end{array}$ \\
\hline 5 & No5E & 5 & $\mathrm{~N} 46 \mathrm{E}$ & 89 & S & Soccer field & $\begin{array}{l}\text { Good displacement } \\
\text { measurement on } \\
\text { offset sidelines. } \\
\text { See fig. } 26 .\end{array}$ \\
\hline 6 & N61E & 1 & N61E & $>60$ & $\mathrm{~S}$ & $\begin{array}{l}\text { Asphalt } \\
\text { highway }\end{array}$ & $\begin{array}{l}\text { Displacement may be } \\
\text { minimum value if } \\
\text { highway fill par- } \\
\text { tially decoupled } \\
\text { from ground. }\end{array}$ \\
\hline 7 & N70E & $\cdots$ & $-\cdots$ & (?) 120 & $\mathrm{~S}$ & Dirt road & $\begin{array}{l}\text { Poor displacement } \\
\text { measurement due to } \\
\text { curve in road. }\end{array}$ \\
\hline 8 & N75E & $3.25-9$ & $\sim N 75 \mathrm{E}$ & 290 & S & Plowed field & - \\
\hline 9 & N80E & 4 & N40E & 20 & $\mathrm{~S}$ & Pasture & $\begin{array}{l}\text { Subsidiary parallel } \\
\text { fault } 1 \mathrm{~km} \text { long, } \\
\text { and } 200 \mathrm{~m} \text { south of } \\
\text { main break. }\end{array}$ \\
\hline 10 & N75E & 2 & -....- & 100 & $S$ & Pasture & $\begin{array}{l}\text { Fair displacement } \\
\text { measured on off- } \\
\text { set cactus fence. }\end{array}$ \\
\hline 11 & N75E & 2 & 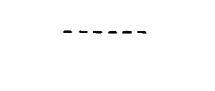 & $\begin{array}{r}105 \\
20\end{array}$ & $\begin{array}{l}S \\
V\end{array}$ & $\begin{array}{l}\text { Cultivated } \\
\text { field }\end{array}$ & $\begin{array}{l}\text { North side down. } \\
\text { See fig. } 25 .\end{array}$ \\
\hline 12 & N75E & -- & $\mathrm{N} 4 \mathrm{OE}$ & 142 & $\mathrm{~S}$ & Pasture & $\begin{array}{l}\text { Fair displacement on } \\
\text { offset path. Splay } \\
\text { to north off main } \\
\text { fault trends N60E } \\
\text { with } 28 \mathrm{~cm} \text { sinistral, } \\
\text { and } 17 \mathrm{~cm} \text { vertical } \\
\text { displacement. }\end{array}$ \\
\hline 13 & - n- & 5 & حN70E & (?) 68 & $S$ & Dirt road & $\begin{array}{l}\text { Poor measurement. } \\
\text { Probably masked by } \\
\text { landsliding. }\end{array}$ \\
\hline
\end{tabular}




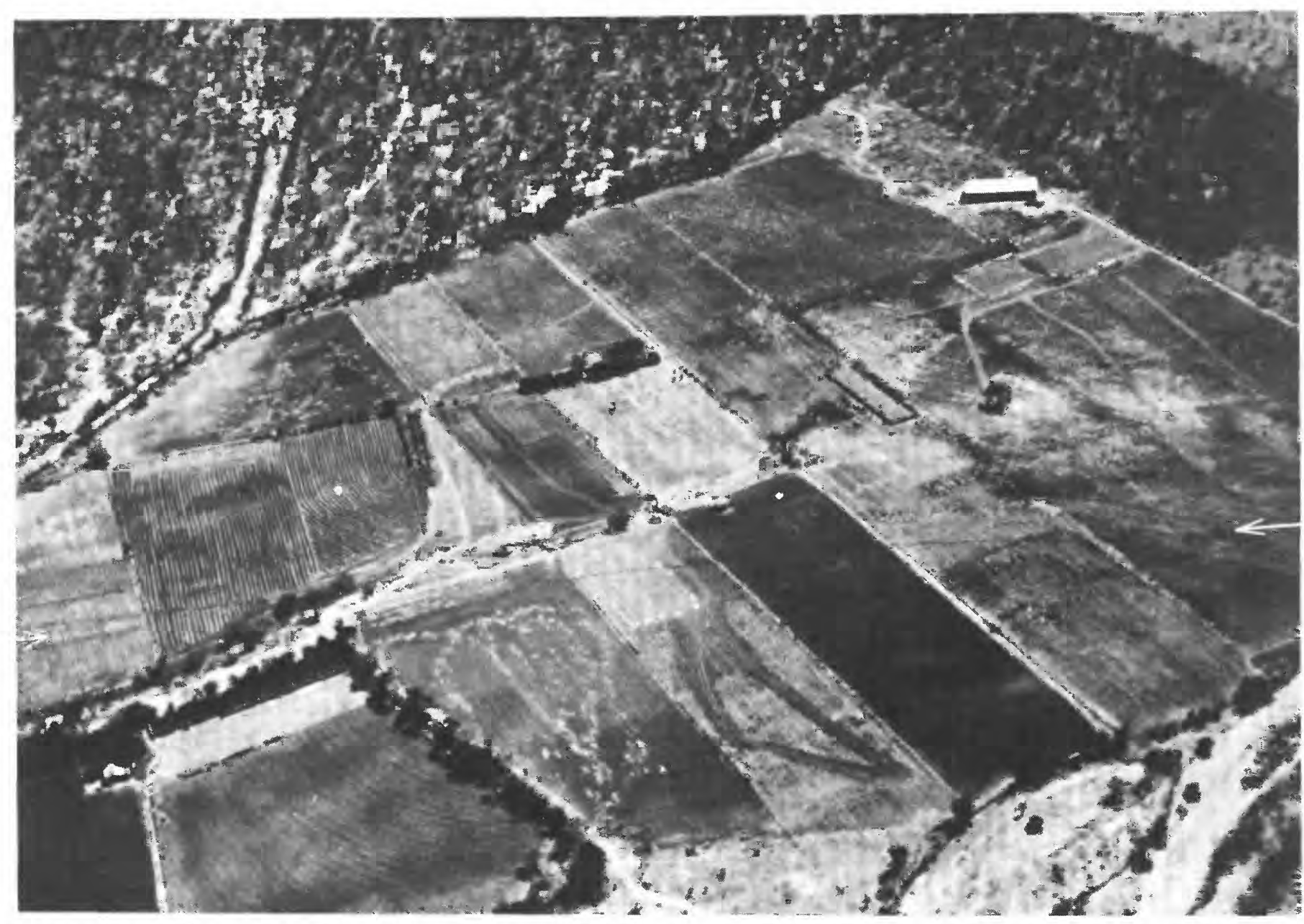

FIGURE 24.-Oblique aerial view looking south towards linear trace of the Motagua fault (arrows) in farmland west of Cabañas. Furrows with sinistral offset may be seen in the field at left. See figure 23 for location of Cabañas.

Faulting during the February 4 earthquake coincided closely with the previously recognized fault on the southern side of the Motagua Valley in the area east of El Progreso (Dengo and Bohnenberger, 1969 ; Bonis and others, 1970). Locally, however, the faulting of February 4 was as far as $1 \mathrm{~km}$ from the Motagua fault as it was mapped before the earthquake. Moreover, faulting related to this earthquake has shown that the Motagua fault extends $85 \mathrm{~km}$ beyond its previously recognized western limits.

Much of the Motagua fault trace is marked by linear stream valleys, minor scarps, shutter ridges, and sag ponds that are suggestive of repeated geologically youthful tectonic activity along this fault. Earthquakes that destroyed Omoa, Honduras, in 1859 (Montessus de Ballore, 1888) and caused damage at Quiriguá (near Las Amates) in 1945 (Seismological Society of America Bulletin, v. 35, p. 194) and at Puerto Barrios in 1929 (Seismological Society of America Bulletin, v. 19, p. 55) may have been generated along the Motagua fault or its offshore extension. However, because surface breaks were not observed and because the epicentral locations are not well constrained by the seismological data, it is not possible to preclude the alternative that these earthquakes were caused by movement on other faults in the area.

\section{RELATIONSHIP OF FAULTING TO DAMAGE}

The Motagua fault break caused extensive damage to buildings, roads, and the railroad. In Gualán, Cabañas, Subinal, and several smaller communities, structures that were astride the fault were damaged by the tectonic displacements. The most intense damage from shaking is within $40 \mathrm{~km}$ of the Motagua fault trace (Espinosa and others, this report) and is predominantly in areas of thick pumiceous ash-flow deposits of Pleistocene age. These poorly consolidated deposits may have amplified ground motions. However, other factors, such as lateral 


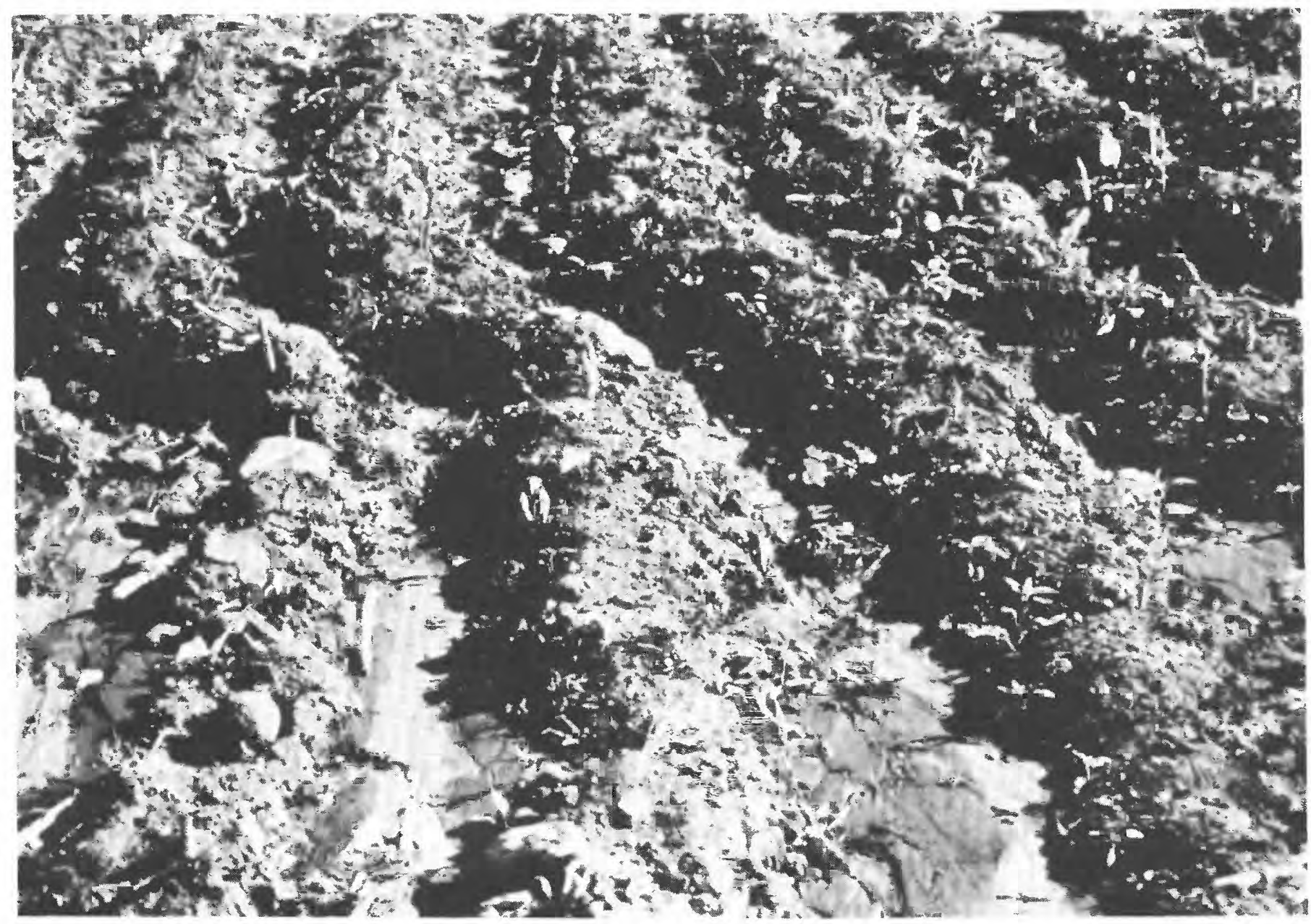

FIGURE 25.-View towards the north showing rows in a cultivated field west of El Progreso (station 11, table 7) that are offset $105 \mathrm{~cm}$ in a sinistral sense by the Motagua fault. See figure 23 for location of El Progreso.

variations in energy release along the fault, construction practices, topography, and movement on subsidiary faults, undoubtedly influence the distribution of damage resulting from seismic shaking.

\section{SECONDARY FAULTS}

Secondary faults (faults which underwent surface displacement approximately concurrent with that on the main fault but which at the surface do not join the main fault) ruptured the ground surface in the Mixco area, in the western part of Guatemala City, and in the area between those cities. Data presently available indicate that the secondary faults occurred as much as $30 \mathrm{~km}$ from the main fault. This distance from the main fault is one of the longest ever documented for secondary faults associated with historic strike-slip faults, and this fact alone makes the study of these faults of international interest. The faults are particularly important to Guatemala for at least two reasons. First, they traverse an urban area, and their future behavior should be considered with regard to present and future land use adjacent to them. Second, the generally north-trending faults near Guatemala City, on some of which the 1976 secondary ruptures occurred, may themselves be capable of producing damaging earthquakes. Even though such earthquakes probably would be of smaller magnitude than those produced by the Motagua system of faults, they could damage Guatemala City because of their proximity.

The following description of the distribution and trends of the secondary faults relies on data gathered by the Sociedad Geológica de Guatemala, which in a remarkably short time prepared a map of the faults. The description of details of the faulting at particular places is based on field examinations by the writers. The secondary faults can be grouped into the three zones indicated in figure 29; individual faults are not shown, primarily because of the scale of the figure. The description of the faults will proceed from west to east. 


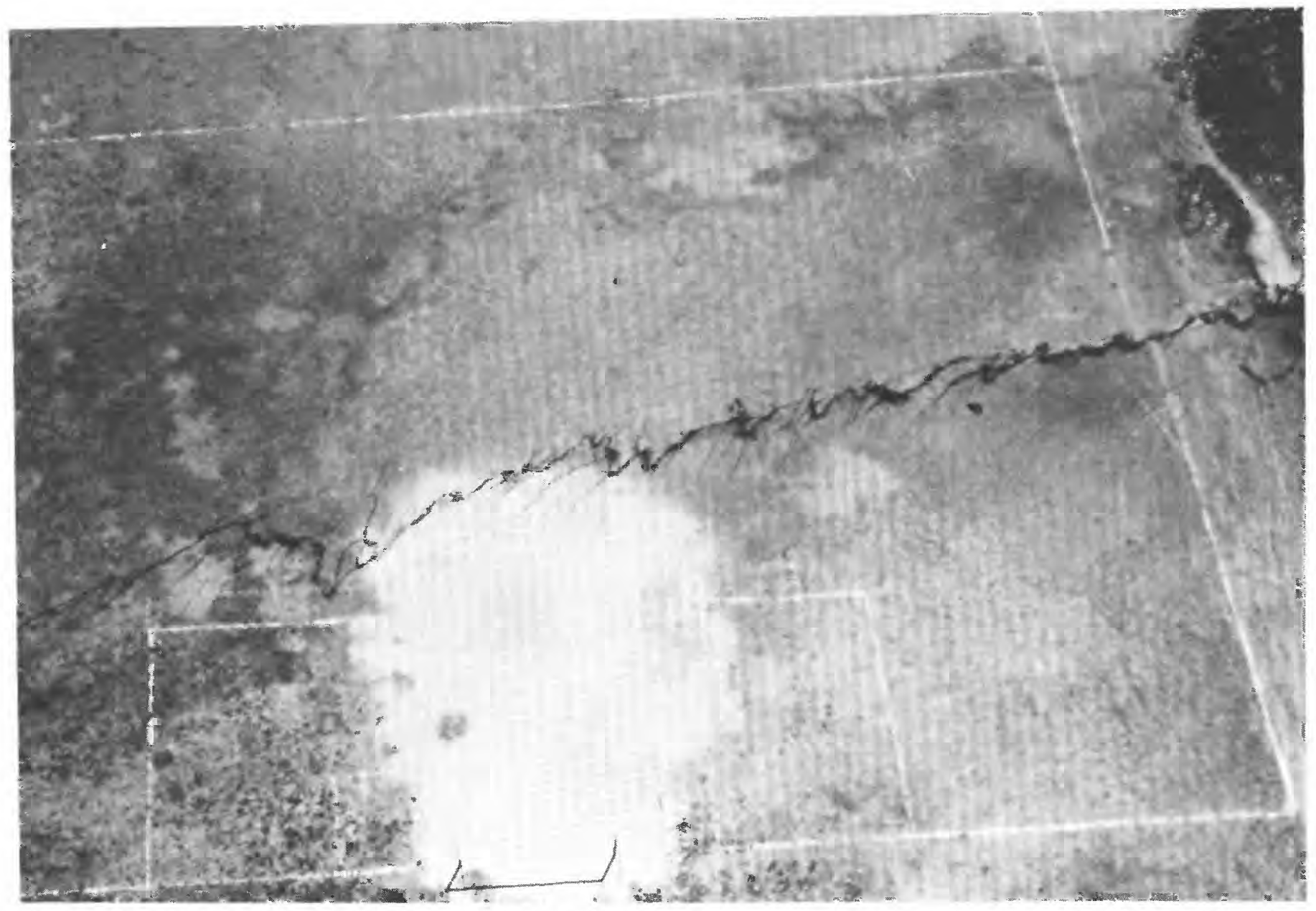

FIGURE 26.-Oblique aerial view of Motagua fault trace crossing a soccer field at Gualán (station 5, table 7). Note characteristic right-stepping en echelon fractures and sinistral offset $(89 \mathrm{~cm})$ of white sideline stripe at right. See figure 23 for location of Gualán.

\section{MIXCO ZONE}

The 1976 surface faults in the Mixco area have been mapped only in reconnaissance, and the general trend, length, and width of the zone of ruptures are uncertain at present. Faults are well developed northeast of La Brigada at locality 1 (fig. 29), and a rupture crossed Highway CA1 just south of Mixco (loc. 2, fig. 29). The bearing between these two points is about N. $27^{\circ} \mathrm{E}$.; however, en echelon faults occur in a broad band that extends to the area east of Ciudad Satellite (loc. 3, fig. 29). If the band is all considered part of the Mixco fault zone, then the trend may be more northerly than N. $27^{\circ}$ E. For the present, the whole band (A, fig. 29) will be considered part of the Mixco zone, but further mapping may require subdivision into two or more zones. Individual faults in the zone commonly strike between N. $10^{\circ} \mathrm{E}$. and N. $30^{\circ} \mathrm{E}$.; their lengths range from about $100 \mathrm{~m}$ to $3.5 \mathrm{~km}$. The total length of the Mixco zone of faults is greater than $10 \mathrm{~km}$.

Three of the faults were examined at and northeast of locality 1 (fig. 29). One of these, traceable for $1.2 \mathrm{~km}$, cut several paved roads and ruptured the curbs and pavement at each crossing (fig. 30). Maximum measured displacement consisted of about $12 \mathrm{~cm}$ vertical slip (down to east) combined with about $5 \mathrm{~cm}$ of right slip, or about $13 \mathrm{~cm}$ of oblique slip. The vertical component was conspicuous at each street crossing, and the right-lateral component, though not conspicuous, could be seen at nearly all the crossings. The fault was essentially vertical, and rifting (displacement of the walls of a fracture perpendicular to the walls (Gill, 1972)) was very minor. In bare ground the fault appeared as a zone of discontinuous cracks, locally en echelon (stepping left), vertical displacement being distributed over a zone of variable width ranging up 


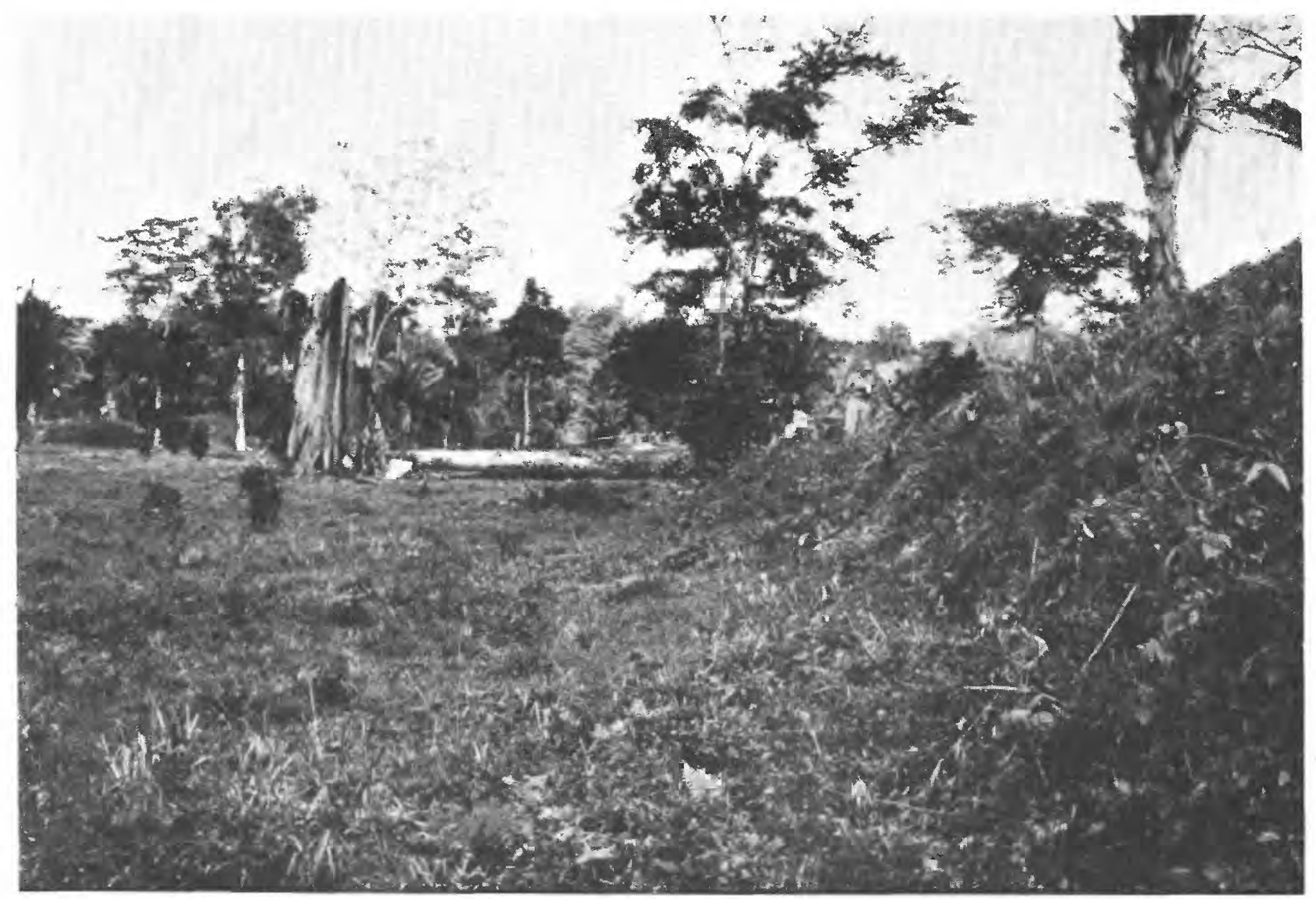

FIGURE 27.-View looking east along fault trace at the most easterly locality visited on the ground (station 1, table 7). Fault trace trends along base of 5-m-high scarp in foreground and through the fallen tree in the distance, which has a base diameter of more than $5 \mathrm{~m}$. The tree was split and toppled by fault movement of about 72-cm sinistral displacement and 37-cm displacement down to the north. The north-facing steep scarp was probably formed by many repeated earlier movements along this same trace.

to about $2 \mathrm{~m}$. Along part of its length the fault coincided with moderately inclined slopes that may be degraded fault scarps.

A second fault, nearly parallel to the first, could be followed for about $1 \mathrm{~km}$. This fault intersected and displaced a high garden wall, passing about 4 $m$ from a house without damaging it. The wall, made of brick with a reinforced concrete beam at midheight, was displaced vertically $13 \mathrm{~cm}$, down on the east; slight right-lateral separation was noted. Over most of its length, this rupture was near the base of a moderately inclined east-facing slope that may be a degraded fault scarp.

A third fault in this general area could be traced for $1.7 \mathrm{~km}$. Its principal displacement was also vertical, down to the east. The vertical displacement measured at a severed garden wall was $12 \mathrm{~cm}$; no strike-slip was noted. The fault passed through a group of concrete-block houses (Husid and others, this report), where its course was marked by vertically displaced roofs and foundations (fig. 31), broken windows, and severely damaged interior and exterior walls (fig. 32). Aerial photographs taken in 1966 before construction of the houses show an east-facing break in slope, probably a degraded fault scarp, that the 1976 rupture followed in part.

\section{VILLA LINDA-CASTANAS ZONE}

A zone of faults (zone B, fig. 29) trending N. $20^{\circ}$ E. extends more than $8 \mathrm{~km}$ from Colonia Villa Linda (loc. 4, fig. 29) to Colonia Castañas (loc. 5, fig. 29). Individual faults in the zone range in length from perhaps $100 \mathrm{~m}$ to $3 \mathrm{~km}$ and commonly strike between N. $18^{\circ}$ E. and N. $31^{\circ}$ E. One of the faults (near loc. 6, fig. 29) was examined briefly from the air and on the ground. It vertically dis- 


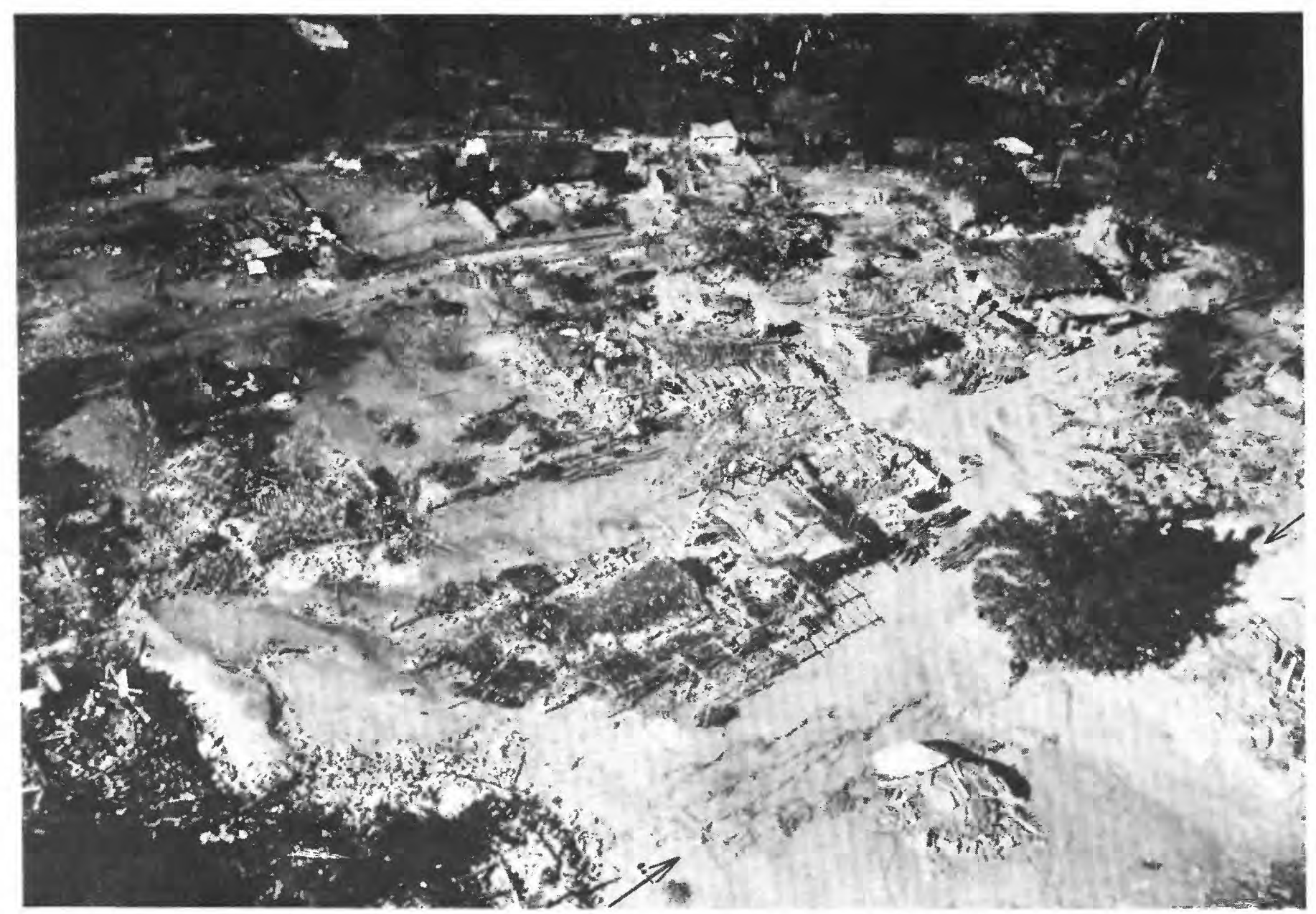

FIGURE 28.-Part of the village of Subinal, $7 \mathrm{~km}$ west of El Progreso, showing the destruction of adobe structures near the Motagua fault trace. The fault is a broad zone of ground cracks that cuts diagonally across the lower right corner of the photograph (arrows).

placed the highway called Anillo Periferico (not shown on fig. 29) by as much as several centimetres, crossed an open field, cracked a masonry wall, and damaged at least two houses to the extent that they had to be vacated. In the open field the fault followed a small steepening in a gentle slope, which suggests that displacements of the same sense (down to the southeast) had occurred along the same line before 1976. In the same area were some deceptive artificial "scarps" resulting from shallow excavations, apparently to obtain topsoil. This fault was followed for about $0.5 \mathrm{~km}$, but others nearby and parallel to it that we did not examine are much longer.

\section{INCIENSO-SANTA ROSA ZONE}

A zone of discontinuous faults (C, fig. 29) extends from the area north of Incienso Bridge (loc.
7, fig. 29) to the vicinity of Colonia Santa Rosa (loc. 8, fig. 29), a distance of more than $7 \mathrm{~km}$. Individual ruptures in the zone are generally less than $1 \mathrm{~km}$ long; strikes generally cluster around N. $19^{\circ}$ E. but vary widely. One fault in the zone displaced the highway northwest of Incienso Bridge about 4 $\mathrm{cm}$, relatively up on the east side. An excellent exposure in the roadcut there shows that the 1976 displacement occurred on a preexisting fault zone that had earlier displacement in the same sense. The earlier displacement, as well as 1976 displacement, was apparent reverse movement, up on the side toward the deep canyon spanned by the bridge. The cumulative displacement was not measured but is clearly several times larger than the 1976 displacement. A paleosol is cut by the fault, and some evidence suggests that the topsoil may have been faulted before 1976 also; thus, it suggests geologically young, pre-1976 movement on the fault. 


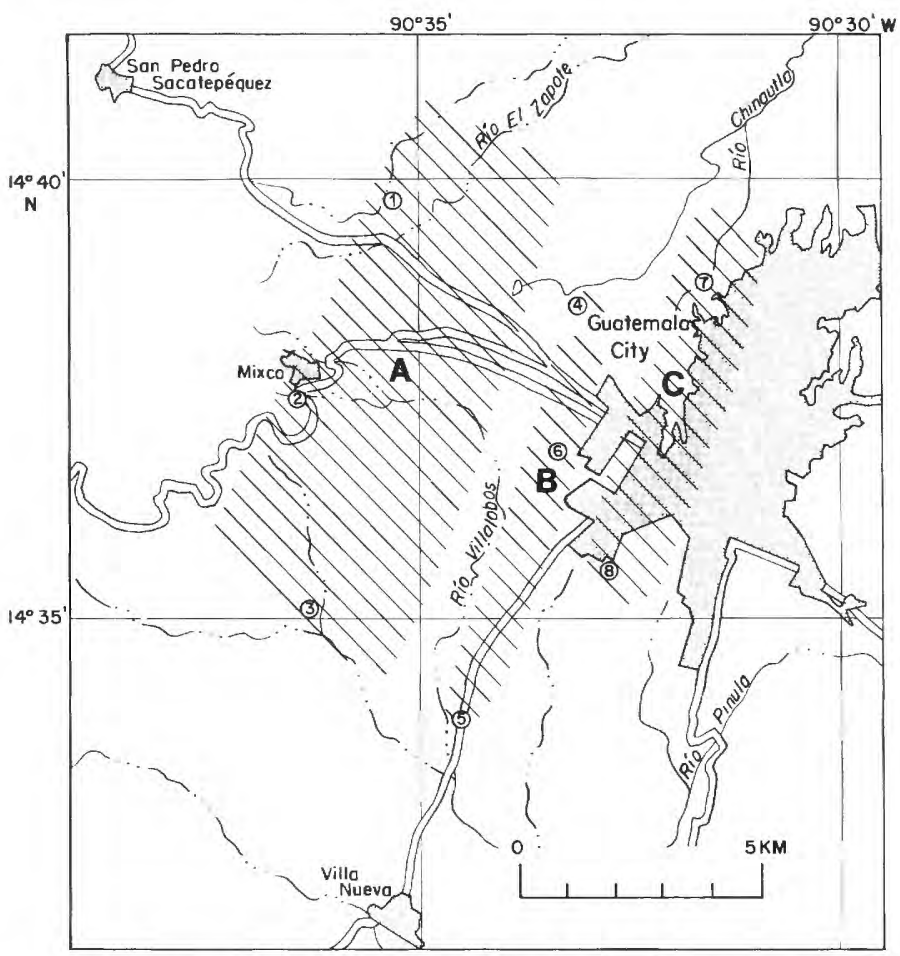

Figure 29.-Zones A, B, and C (hatched areas) of secondary faults, and numbered localities discussed in text. A, Mixco zone; B, Villa Linda-Castañas zone; C, Incienso-Santa Rosa zone.

\section{REGIONAL TECTONIC RELATIONS OF EARTHQUAKE FAULTS}

The Motagua fault is part of a complex zone consisting of four major subparallel arcuate fault zones that trend in a general east-west direction across Guatemala and northern Honduras. As used in this paper, these are the Motagua and San Agustín fauits in the Motagua Valley; the Polochic zone to the north, comprised of the Polochic and Chixoy (not labeled in fig. 23) faults; and the Jocotán Jocotán and Chamelecón faults (fig. 23). For convenience, this broad group of faults is referred to zone to the south, which consists primarily of the herein as the Motagua fault system.

The nature of the faults in this system and their relationship to the Cayman Trough (also referred to as Bartlett Trough) and the tectonics of the Caribbean region have been the subject of much study and speculation. Most workers agree that the faults in the Motagua system are old fundamental breaks that have undergone recurrent displacement at least since the late Paleozoic. Some have postulated large sinistral displacements on the faults in this zone during the Cenozoic, although significant vertical movements occurred during the earlier history of

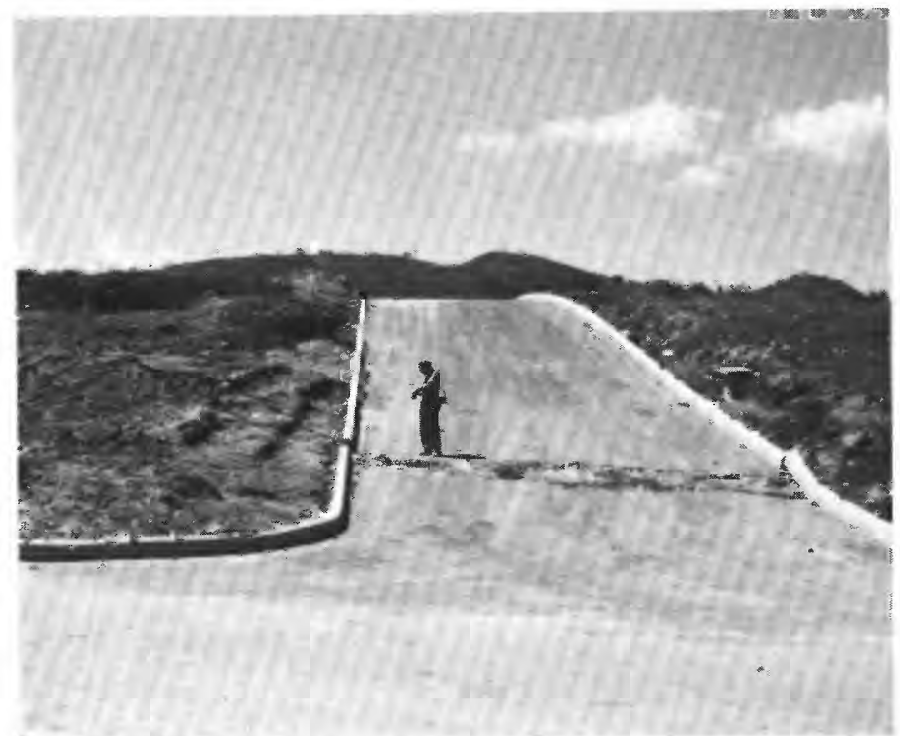

FIGURE 30.-Fault displacement of road at locality 1 (fig. 29). Note right-lateral component of displacement.

the zone. Excellent recent comprehensive summaries of the onshore geologic data relevant to the tectonic development of the region, including extensive bibliographies, have been given by Dengo (1968), Dengo and Bohnenberger (1969), Malfait and Dinkelman (1972), and McBirney and Bass (1969). Data on seismicity and marine geology and geophysics in the Caribbean and their relationship to plate-tectonics models have been presented by Molnar and Sykes (1969) and Jordan (1975).

The secondary faults of the Guatemala CityMixco area are part of a system of predominantly dip-slip faults in Guatemala, western Honduras, and El Salvador that lie between the Motagua fault and the chain of stratovolcanoes that passes through the highlands of Guatemala and El Salvador (Dengo, 1968; Williams and others, 1964; Williams and McBirney, 1969). As shown in figure 23, these secondary faults group roughly into three sets that may in part reflect reactivated fractures in the crystalline basement rocks. The dominant set trends generally north to north-northeast; in a number of places, faults in this set bound prominent structural depressions such as the graben in which Guatemala City is located, the Ipala Graben of eastern Guatemala and western El Salvador, the Ulúa Graben in western Honduras, and a series of grabens along the Chamelecón-Jocotán fault zone. A second important set of faults is located along, and approximately parallel to, the northwest-trending chain of stratovolcanoes (fig. 23) that comprise the Middle America volcanic arc. This set of faults becomes 


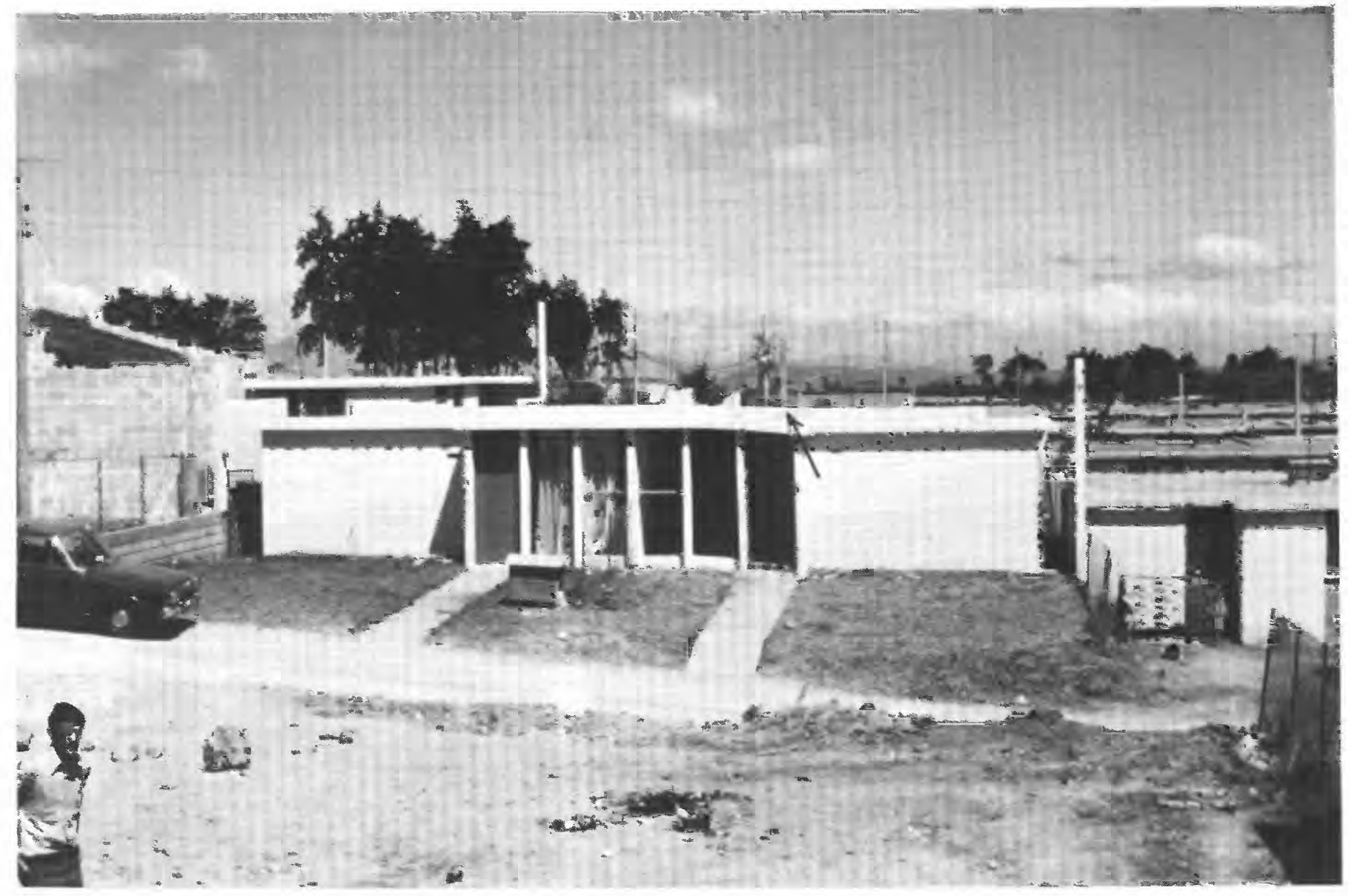

Figure 31.-Fault damage to a house in Guatemala City. The roof, foundation, and sidewalk have been displaced vertically.

increasingly prominent towards the southeast, where it bounds the central trench of El Salvador and the broad Nicaragua Depression (Williams and others, 1964, fig. 5; Dengo, 1968, fig. 9). A third set of oblique faults, not shown in figure 23, strikes northeast; it is locally well developed in the southeastern part of Guatemala and is present in much of the adjacent area to the southeast (Williams and others, 1964). Although detailed studies of the displacement histories of these faults have not been published, there can be little doubt that many of them are geologically youthful features. Most of them offset upper Tertiary or Quaternary deposits, in places they are marked by prominent scarps that border topographic depressions, and some of them serve as conduits for Quaternary volcanic eruptions.

Available data on the 1917-18 series of moderatesized earthquakes that heavily damaged Guatemala City raise the possibility that those earthquakes may have originated on faults south or southwest of the city. The description by Vassaux (1969, p. 18-22) shows that Amatitlán and Villa de Guadalupe, both south of Guatemala City, sustained more damage than the city proper in the November 17, 1917, earthquake, which initiated the destructive series. Vassaux $(1969$, p. 21) concludes that there were at least two centers of activity during the series, including Petapa (about $15 \mathrm{~km}$ south-southwest of Guatemala City) and Escuintla $(45 \mathrm{~km}$ southwest of Guatemala City). However, we suggest that the most likely cause of these earthquakes was a series of fault displacements on the Mixco system and, perhaps, on the extension faults that bound the graben in which Lake Amatitlan is situated (about $16 \mathrm{~km}$ south of Guatemala City).

\section{LANDSLIDES}

The main event and some of the large aftershocks triggered numerous landslides throughout a broad region of central Guatemala parallel to the main fault and extending as far westward as long $91^{\circ} 30^{\prime}$ W. (fig. 33). The landslides, numbering in the thousands, were mainly falls, slides, and flows involving thick pumiceous pyroclastic rocks, but they also included slides of consolidated bedrock (figs. 34 and 35 ). The overwhelming majority of the 


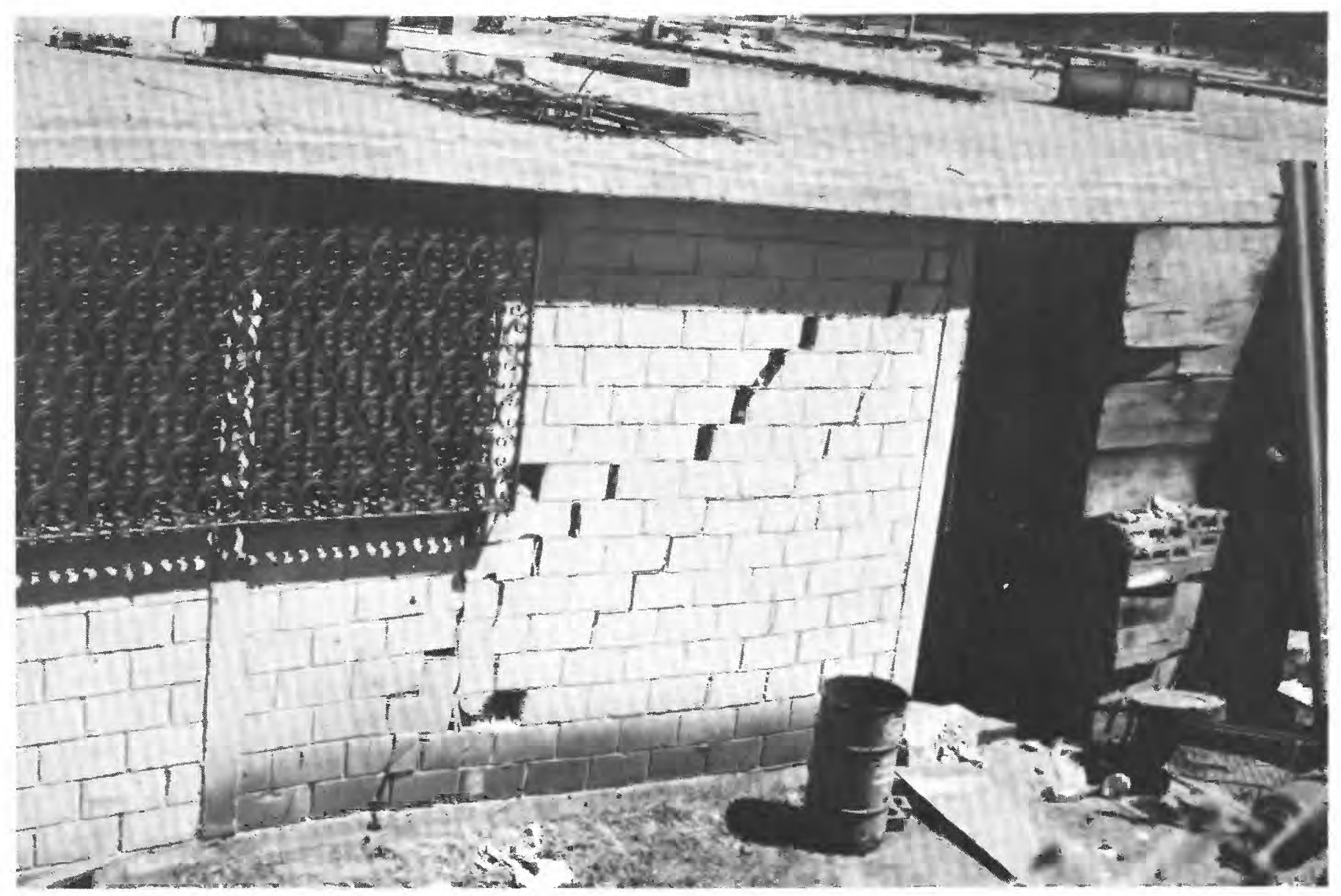

FIGURE 32.-Fault damage to the rear exterior wall and roof of a house in Guatemala City. Vertical displacement near the front of the house was $12 \mathrm{~cm}$.

slides occurred along the steeper slopes of the deeply incised drainages in the Guatemalan highlands and at the larger road and railroad cuts and fills. They blocked many transportation routes, interrupted surface communication lines, and in places damaged structures built in their paths (fig. 36).

Some of the larger slump blocks and rotational slumps observed contain several million cubic metres of material. A number of these larger slides (indicated in fig. 33) have formed natural dams behind which lakes are developing (fig. 37). Such lakes are potentially hazardous because, when the dams are overtopped, rapid erosion and relatively sudden breakout could cause catastrophic flooding of inhabited areas and communication routes downstream.

Many highland drainages are choked with landslide debris, particularly those areas of intense landsliding shown by a distinctive pattern in figure 33 . This debris could become sufficiently water saturated during the rainy season (June through October) to become mobilized and move as debris flows either naturally or as a result of aftershock activity. Such flows could pose a major hazard to communities and transportation routes situated downstream.

\section{LANDSPREADING, FISSURING, SUBSIDENCE, AND SAND MOUNDS}

Landspreading, involving near-horizontal movement of mobilized or liquefied water-saturated granular deposits toward free faces, occurred at a number of localities in the Motagua Valley, along the Atlantic coast in Guatemala and Honduras, and along some lake shores in the highlands (fig. 33). Extension cracking and subsidence that accompanied the spreading damaged structures in many of these areas.

Throughout the lower Motagua Valley and part of the Chamelecón Valley in Honduras, widespread fissuring and settling of sediments in areas of high water table have caused damage to irrigation facilities, roads, levees, railroads, buildings, and pasture lands. At many localities, the compaction of satu- 


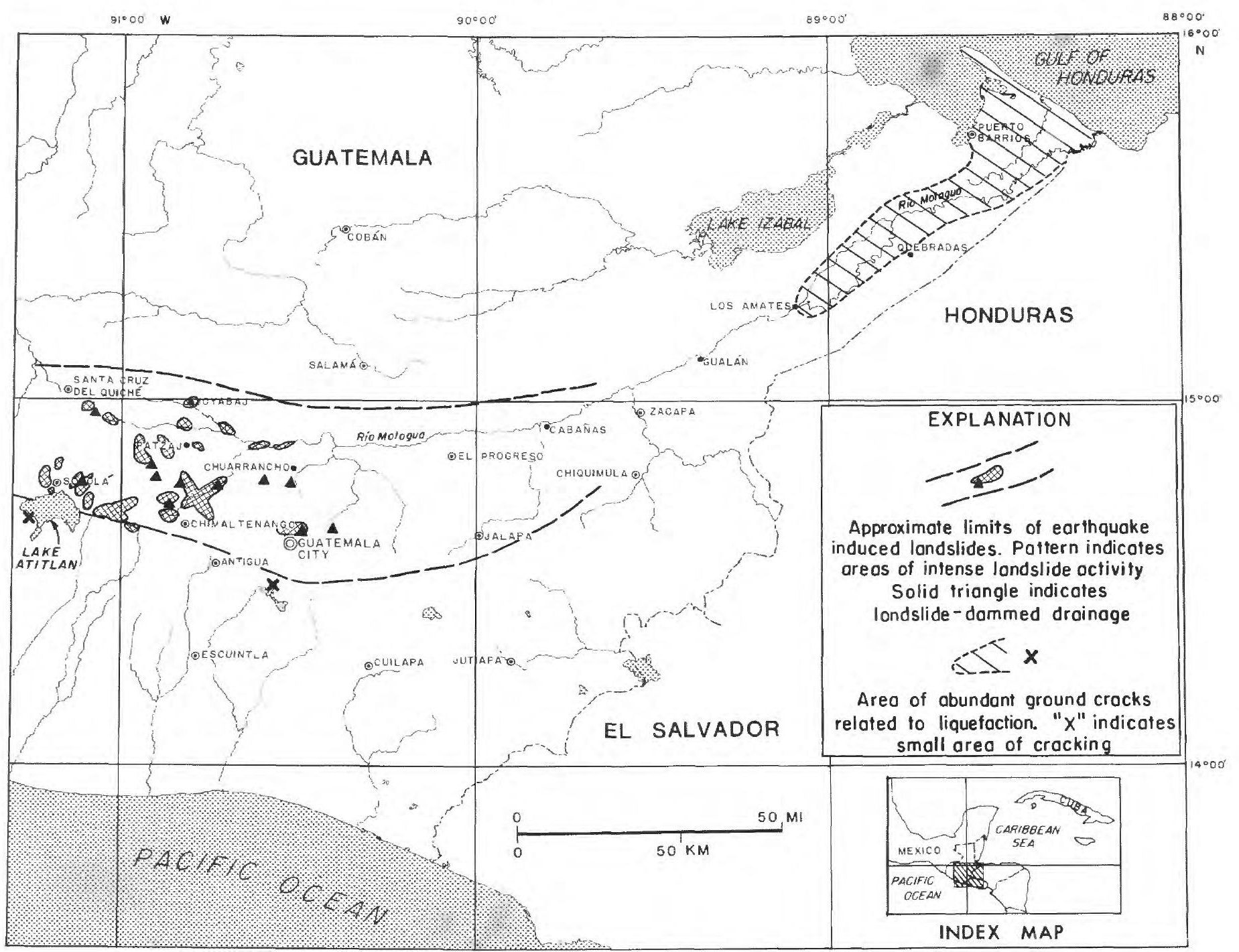

FIGURE 33.-Areas of earthquake-induced landslides and of ground cracks probably related to liquefaction of unconsolidated deposits. Landslide distribution is from a preliminary study of post-earthquake aerial photographs by Edward Harp, Ray C. Wilson, and Gerry Wieczorek of the U.S. Geological Survey.

rated materials was accompanied by ejection of water or water-sediment mixtures and the formation of sand mounds (figs. 38 and 39). Similar effects of sediment liquefaction were observed in the delta on the northern side of Lake Amatitlán near Guatemala City and along the shore of Lake Atitlán; they reportedly occurred as far away as Lake Ilopango in El Salvador.

\section{VOLCANIC ACTIVITY}

There is no indication that the main event or any of its aftershocks were related to volcanic activity. One of the writers (Bonis), who studies the active volcanoes of Guatemala on a continuing basis, believes that the amount of ash erupted from the
Volcano Pacaya, located south of Guatemala City, may have increased slightly but that the apparent increase is well within the limits of the prequake variations in the volcano's activity.

Numerous reports have been received of steam suddenly venting from the ground after the earthquake or of changes in hot-spring activity. Because this area is characterized by widespread and abundant thermal activity related to the volcanoes or their deposits, such reports are to be expected. Those reported anomalies that have been checked by geologists, however, suggest that there is no evidence of dramatic new volcanic activity initiated by the earthquake that could be a hazard to life or property. 


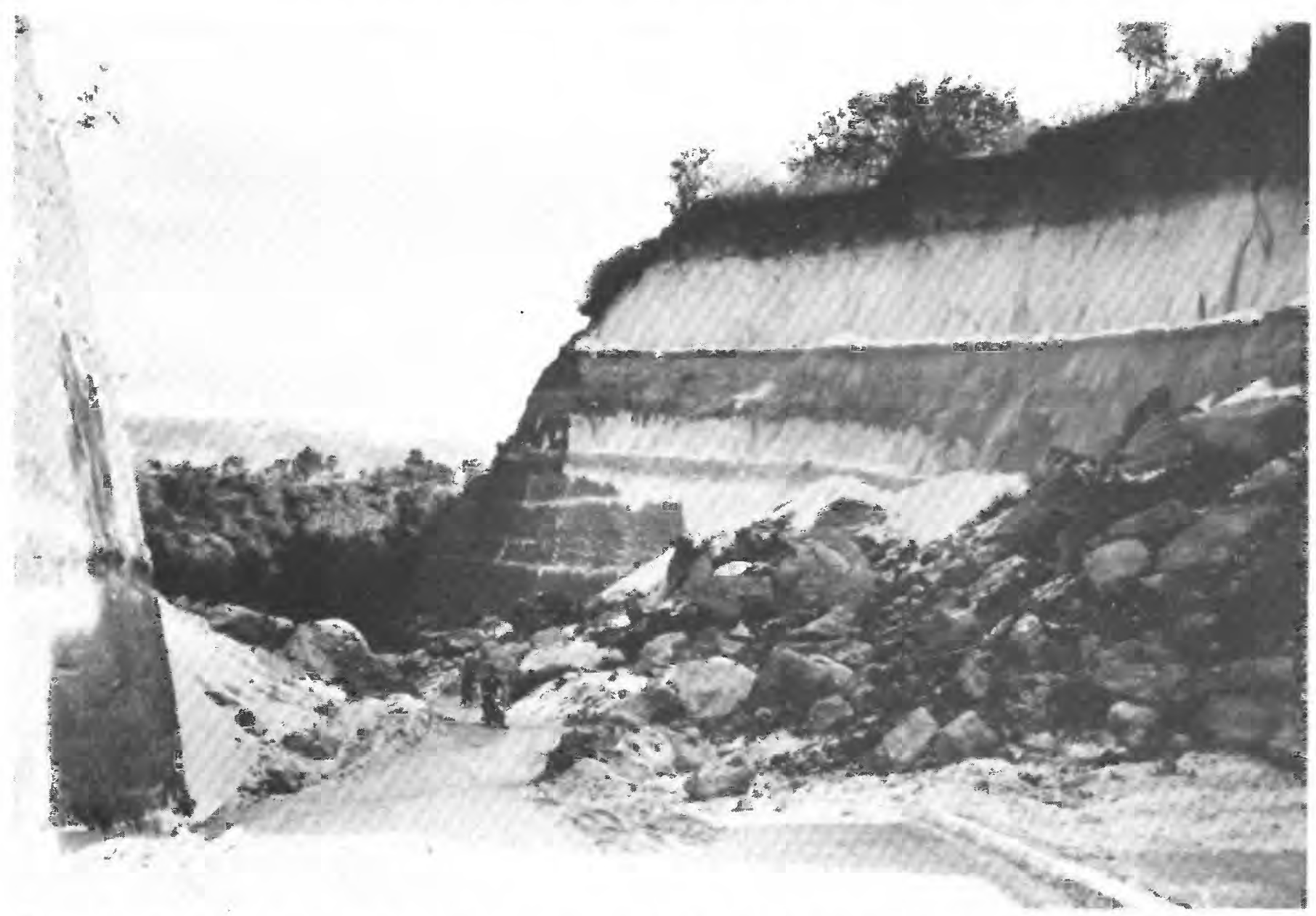

FIGURE 34.-Landslides in steep road cut in stratified pumice and ash deposits at San Cristobal, west of Guatemala City.

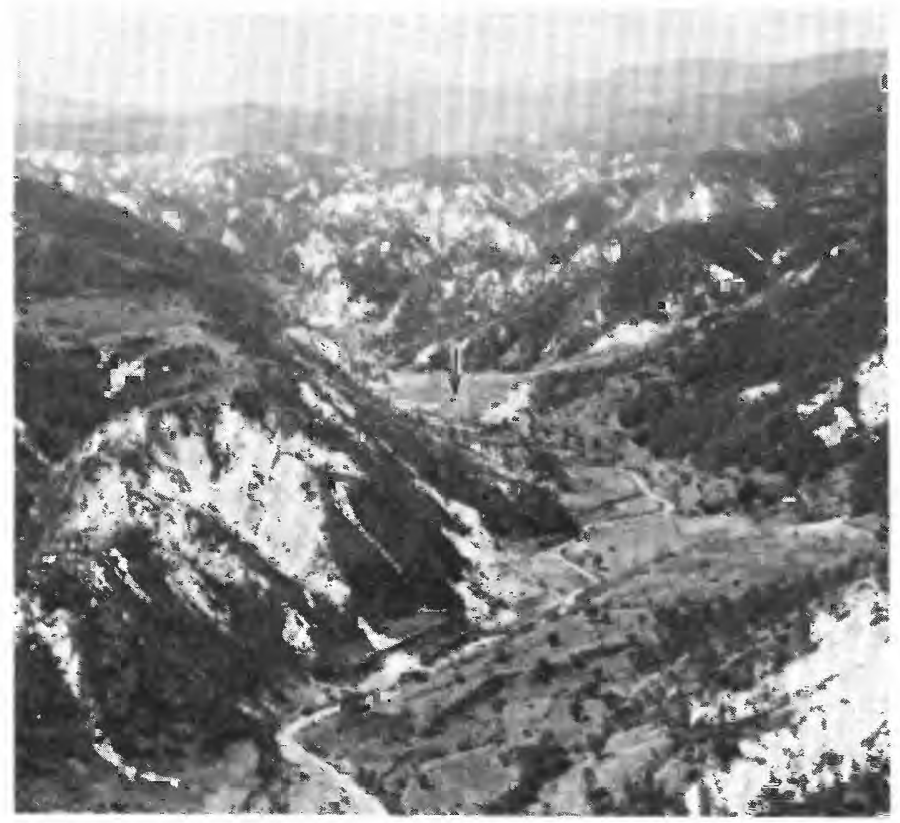

FIGURE 35.-Aerial view looking northeastward along Río Pixcayá, due north of Chimaltenango, showing numerous landslides in pyroclastic deposits. The river was partially dammed by a major landslide, shown by arrow in the middle distance. (Also see fig. 37.)

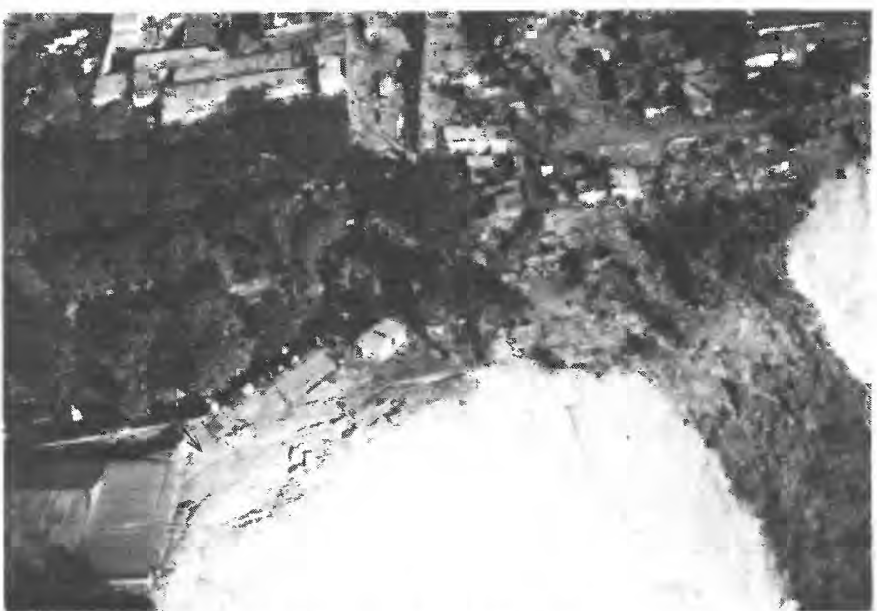

FIGURE 36.-Aerial view of landslide in pyroclastic deposits near the edge of a steep-sided gully (barranco) in Guatemala City. Slides such as this (as shown by arrow) and their associated headwall cracking caused extensive damage to homes, roads, and other facilities in the northern part of the city. 


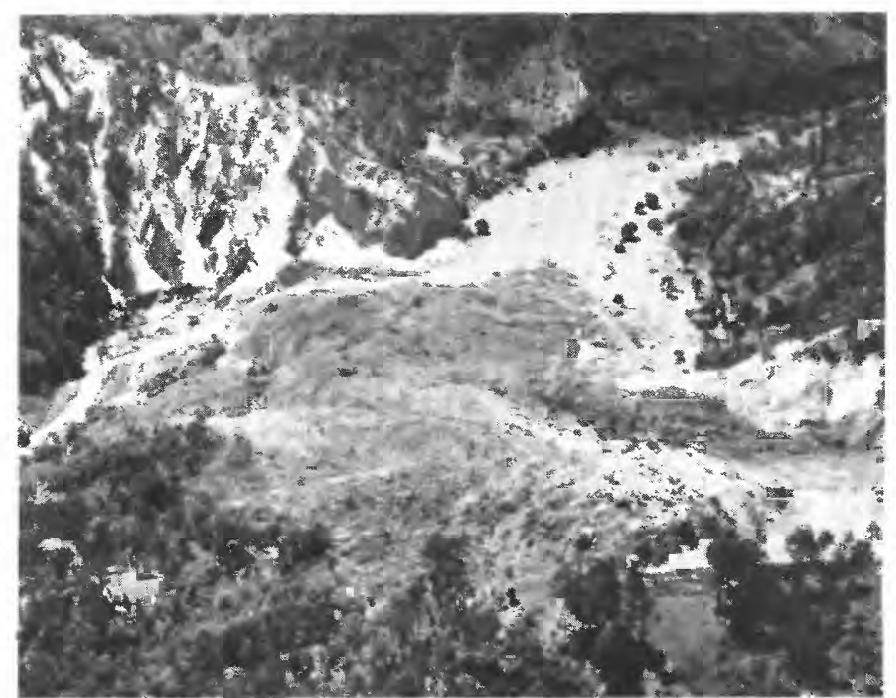

Figure 37.-Landslide-dammed lake along Río Pixcayá. The toe of the dam had been breached by the river by the time this photograph was taken on February 13.

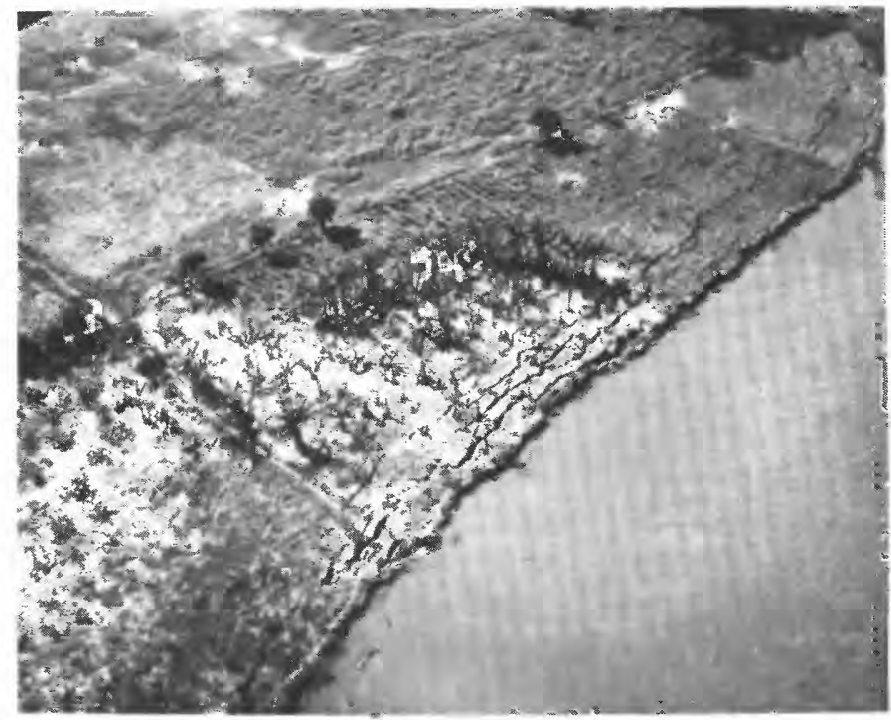

Figure 38.-Aerial view of ground cracks and sand mounds (white patches) in unconsolidated alluvial deposits along the Motagua River north of Quebradas in the lower Motagua Valley. Ground cracks are believed to result from liquefaction of water-saturated sediments and spreading towards the river channel.

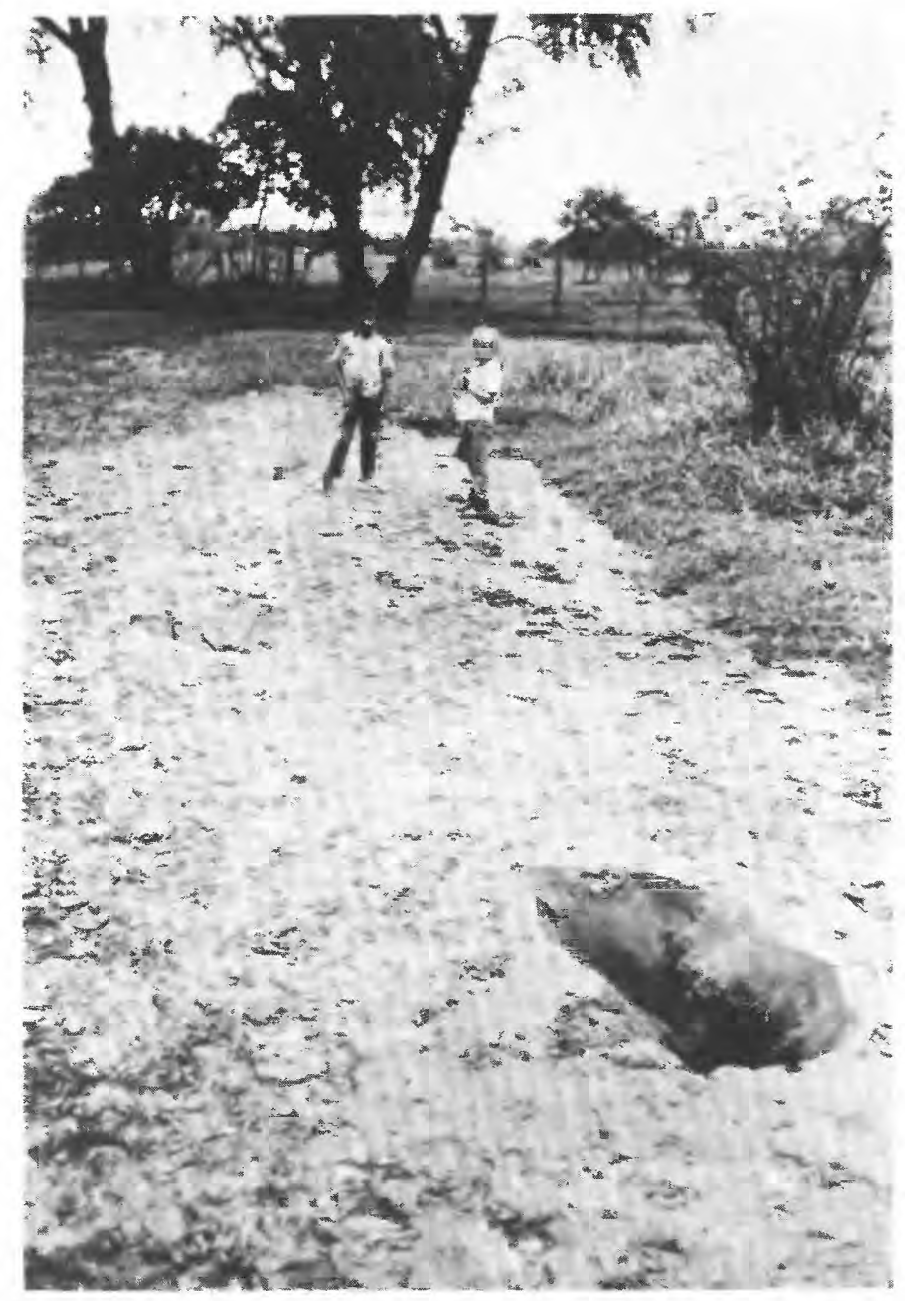

FIGURE 39.-View of linear sand mounds and circular to elliptical craters in area of water-saturated unconsolidated deposits along the Motagua River. 


\title{
INTENSITY DISTRIBUTION AND SOURCE PARAMETERS FROM FIELD OBSERVATIONS
}

\author{
By Alvaro F. Espinosa, Raul Husid, and Antonio Quesada ${ }^{4}$
}

\section{INTRODUCTION}

The earthquake of February 4 in Guatemala was felt over an area of at least $100,000 \mathrm{~km}^{2}$. It originated on the Motagua River Valley to the east of Los Amates and propagated west along the Motagua fault through Gualán and El Progreso to Chuarrancho (details of the surface faulting mapping are given by Plafker and others, this report). The sense of motion from field observations as well as from instrumental seismic determination (Dewey and Julian, this report) is a left-lateral strikeslip fault.

This paper is a preliminary report on the earthquake-damaged area studied during the period February 6-22. The purpose was to obtain information in Guatemala City and along the Motagua fault area to delineate the distribution of intensities (Modified Mercalli), damage to adobe-type structure, strong motions, and other related phenomena.

The ground movement in the fault zone was very severe, and numerous estimates of the time duration of strong shaking range between 30 and $40 \mathrm{~s}$. The first movement was vertical and was followed by a strong horizontal ground motion, which was so strong that it hindered people from getting out of bed, and in many instances people were thrown down or were unable to walk. In many areas of the country, a second intense horizontal motion was reported nearly a minute after the main disturbance. In one particular case illustrating the last report, a man tried to get out of bed and failed. $\mathrm{He}$ waited several seconds and tried again, failing for the second time. He stayed in bed for about $30 \mathrm{~s}$, and then he was able to get up, pick up a child from a crib, and go out. As he was going out, he felt the second severe horizontal ground motion, which collapsed his house.

\footnotetext{
Organization of American States, Washington, D.C.
}

\section{CASUALTIES AND DAMAGE}

The statistics for casualties and damage are given in table 8 by Departments and in table 9 by municipalities. These figures were provided by the Comite Nacional de Emergencia, Presidencia de la Republica de Guatemala. The total number of houses destroyed, as of February 15, 1976, was 254,750 , and 1.07 million people were left homeless. From a total population of $3,213,962$, there were 22,868 deaths and 77,190 injuries as of March 3, 1976. The total loss in Guatemala is $\$ 1,100$ million (from Ministry of Finance statistics).

\section{INTENSITY DISTRIBUTION IN GUATEMALA}

The areas of maximum Modified Mercalli intensity are concentrated in and near the town of Gualán, Department of Zacapa, and to the west in the town of Mixco, Department of Guatemala. Maximum intensity in the meizoseismal area was IX. In the Gualán area, however, much of the damage could be classed as VIII. On the Modified Mercalli scale (Richter, 1958), large landslides, such as those that developed between Guatemala City and El Progreso and also between Guatemala City and Antigua, suggest an intensity greater than IX. Another factor that yields higher intensities is surface faulting, examples of which were observed in Gualán (see cover photograph) and along the Motagua fault. The authors visited, by car and helicopter, villages in areas of high, intermediate, and low damage and by using questionnaires gathered data (fig. 40) used to assess the Modified Mercalli intensity ratings throughout the nation.

These intensities are rated by using the abridged version of the Modified Mercalli intensity scale (Richter, 1958), with the following exceptions: landslides are not rated in this report as intensity $\mathrm{X}$; rails bent greatly are not rated as intensity $\mathrm{XI}$; and destroyed bridges are not rated as intensity XI. 
TABLE 8.-Casualties and damage, by Departments

\begin{tabular}{|c|c|c|c|c|}
\hline Department (state) & Population & Deaths & Injuries & $\begin{array}{r}\text { Percent } \\
\text { damage }\end{array}$ \\
\hline Guatemala & $1,681,736$ & 3,370 & 16,549 & 68.82 \\
\hline El Progreso & 78,364 & 2,028 & 7,767 & 90.43 \\
\hline Sacatepéquez & 105,210 & 1,582 & 8,855 & 71.00 \\
\hline Chimal tenango & 214,290 & 13,754 & 32,392 & 88.00 \\
\hline Santa Rosa & 20,591 & 40 & 291 & 1.60 \\
\hline Solola & 30,707 & 110 & 300 & 10.00 \\
\hline Totonicapán & 162,678 & 27 & 89 & 34.00 \\
\hline Quezal tenango & 79,241 & 14 & 228 & 1.00 \\
\hline Huchuetenango & 34,362 & 10 & 50 & N.A. ${ }^{1}$ \\
\hline Quiché & 150,073 & 843 & 5,722 & 73.00 \\
\hline Baja Verapáz & 49,820 & 152 & 718 & 82.50 \\
\hline Al ta Verapáz & 59,664 & 18 & 953 & 67.50 \\
\hline Izabal & 183,370 & 73 & 379 & 40.00 \\
\hline Zacapa & 107,148 & 693 & 1,998 & 72.86 \\
\hline Chiquimula & 76,603 & 50 & 378 & 50.00 \\
\hline Jal apa & 88,802 & 91 & 473 & 31.67 \\
\hline Jutiapa & 91,303 & 13 & 48 & 10.00 \\
\hline
\end{tabular}

${ }^{1}$ N.A. - Information not available.

These exceptions have been made because the Modified Mercalli intensity scale is used to represent the intensity of an earthquake based on purely vibrational effects as well as on the damage sustained by structures from the earthquake. The above effects are of a secondary nature to the seismic energy release. In the area of heavy landsliding, many adobe houses sustained no damage. Landsliding implies intensity $\mathrm{X}$, but undamaged adobe houses suggest much lower intensities (fig. 41). Also, numerous houses near landslides along the highways toward the Pacific were not damaged.

Rails bent greatly are not related directly to ground shaking, but this effect is related to ground movement due to faulting, as seen in Gualán (fig. $42 A$ ) and near El Jicaro (fig. $42 B$ ), or to ground compaction, as observed in Puerto Barrios (fig. $42 C)$. Another factor that yields higher intensities is surface faulting, examples of which are observed in Gualán (see cover photograph) and along the Motagua fault, near Las Ovejas (fig. $42 D$ ).

The Agua Caliente Bridge was destroyed, and the Benque Viejo Bridge was at the verge of collapse owing to large ground displacement in those areas. The displacements sustained by the Agua Caliente Bridge were larger than those planned in the original design for the structure. The damage to these structures gives an indication of the severity of the ground deformation but does not indicate the level or the time duration of the seismic disturbance. The Benque Viejo Bridge is similar in construction to some of the highway overpasses in the San Fernando Valley of California, which collapsed as a result of the 1971 San Fernando earthquake.

The isoseismal map shown in figure 43 represents a preliminary Modified Mercalli intensity dis- 
TABLE 9.-Casualties and damage, by municipalities

\begin{tabular}{|c|c|c|c|c|}
\hline Municipality & Population & Deaths & Injuries & \% Damage \\
\hline 1.* Chimaltenango & 20,194 & 600 & 3,000 & $25 \%$ \\
\hline 2. San Jose Poaquie & 9,795 & 1,000 & 2,657 & $90 \%$ \\
\hline 3. San Martin Jilotepeque & 33,066 & 2,920 & 5,000 & $100 \%$ \\
\hline 4. Zaragoza & 7,317 & 300 & 1,000 & $100 \%$ \\
\hline 5. Patzicia & 10,585 & 811 & 2,248 & $90 \%$ \\
\hline 6. Sta. Cruz Balanya & 2,903 & 100 & 500 & $80 \%$ \\
\hline 7. Tecpan & 24,181 & 3,023 & 7,000 & $100 \%$ \\
\hline 8. Patzun & 18,900 & 309 & 390 & $85 \%$ \\
\hline 9. Parramos & 3,237 & 200 & 900 & $90 \%$ \\
\hline 10. EI Tejar & 3,039 & 50 & 900 & $85 \%$ \\
\hline 11. San Andres Itzapa & 8,447 & 150 & 728 & $90 \%$ \\
\hline 12. Yepocapa & 10,457 & 87 & 289 & $90 \%$ \\
\hline 13. Comalapa & 18,163 & 3,050 & 5,000 & $95 \%$ \\
\hline 14. Sta. Apolonia & 4,182 & 900 & 844 & $85 \%$ \\
\hline 1. Guatemala & 700,504 & 1,195 & 5,550 & $45 \%$ \\
\hline 2. San Pedro Sacatequepez & 10,714 & 720 & 1,667 & $100 \%$ \\
\hline 3. San Juan Sacatepequez & 43,116 & 720 & 2,400 & $100 \%$ \\
\hline 4. Chuarrando & 6,985 & 42 & 1,789 & $60 \%$ \\
\hline 5. Sn. Raymundo & 9,225 & 118 & 1,543 & $60 \%$ \\
\hline 6. San Pedro Ayampuc & 10,481 & 54 & 316 & $90 \%$ \\
\hline 7. Mixco & 129,878 & 346 & 2,400 & $80 \%$ \\
\hline 8. Amatitlan & 26,412 & 16 & 80 & $20 \%$ \\
\hline 9. Palencia & 18,982 & 68 & 157 & $85 \%$ \\
\hline 10. Villa Canales & 31,774 & 2 & 100 & $20 \%$ \\
\hline 11. Sn. Miguel Petapa & 8,078 & 2 & 140 & $70 \%$ \\
\hline 12. Sta. Catarina Pinula & 12,934 & 9 & 70 & $75 \%$ \\
\hline 13. Chinautla & 32,763 & 50 & 15 & $80 \%$ \\
\hline 1. Progreso Cabecera & 11,048 & 1,300 & 3,500 & $95 \%$ \\
\hline 2. El Jicaro & 6,197 & 372 & 2,538 & $100 \%$ \\
\hline 3. San Agustin Acasagustlan & 17,344 & 126 & 917 & $50 \%$ \\
\hline 4. Morazan & 7,080 & 134 & 570 & $100 \%$ \\
\hline 5. Sanarate & 15,253 & 69 & 137 & $70 \%$ \\
\hline
\end{tabular}

tribution of the main event in Guatemala. The isoseismal for an intensity rating VII follows the general trend of the mapped Motagua fault. The isoseismal VIII, and higher, in the Departments of Sacatépequez, Chimaltenango, Guatemala, and the southern part of Quiché, follows the general trend of maximum adobe-damaged areas.

The high intensities attenuate faster in the eastern part of the country near Los Amates. However, as one progresses west, from El Jicaro to near Sanarate, the intensities increase in a narrow area, and then, outside Sanarate, there is a sudden intensity decrease for the next $35 \mathrm{~km}$ and again a rather large increase to Modified Mercalli intensities of VIII and IX in the Mixco area. Guatemala City, as it appears on this map, has been assigned an average intensity of VII and, in the northern part of the city, an intensity rating of VIII. A detailed mapping of the intensity distribution in Guatemala City associated with the February 4 earthquake is now being done and will be presented in a subsequent separate report.

A study of intensity distributions unexpectedly showed that a number of small villages near the causative fault sustained no damage. The intensity ratings attenuate rather rapidly in a north-south direction in the eastern part of the country.

The epicenter was located west of the town of Los Amates, approximately $12 \mathrm{~km}$ away. The highest intensities were in Gualán and $145 \mathrm{~km}$ due west in Mixco. In Guatemala City, the intensity was IX in the center of the city. To the northwest of the city, the intensity was VIII along the strike of some faults mapped after the earthquake.

The intensity VII isoseismal has an east-west trend, from Los Amates, parallel to the Motagua 
TABLE 9.-Casualties and damage, by municipalities-Continued

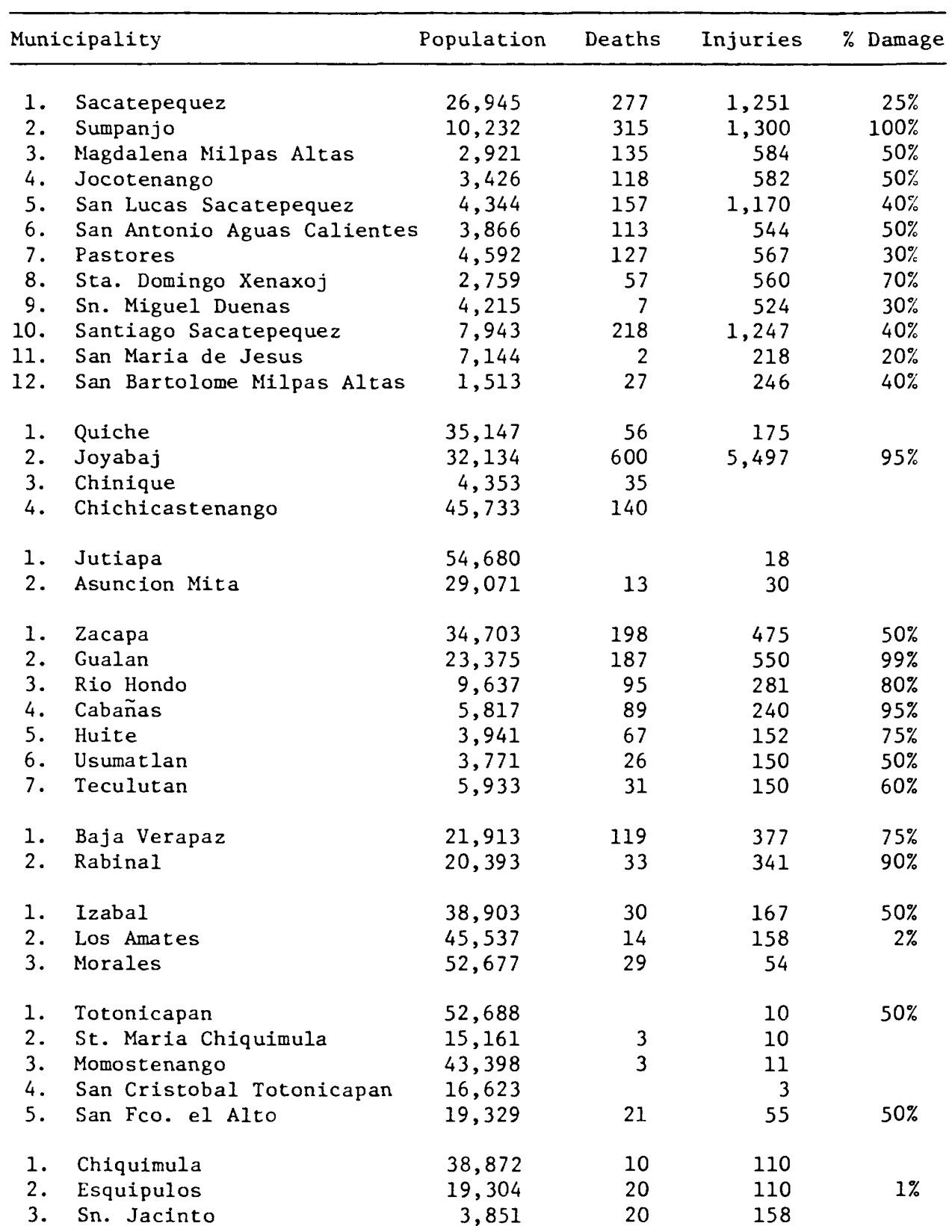

fault for a distance of $150 \mathrm{~km}$ to near San Antonio $\mathrm{La} \mathrm{Paz}$ in the Department of El Progreso. From San Antonio to Zaculeu in the Department of Quiché, an east-west distance of another $85 \mathrm{~km}$, the intensity VII isoseismal broadens considerably to $72 \mathrm{~km}$ in width. The intensity VIII and IX isoseismals follow a trend parallel to the trend of surface faulting. The dashed line is questionable for the intensity VIII isoseismal continuation to the west between Sanarate and to the east of Guatemala City. The number of landslides in this area was very high, on the average one landslide per kilometre.
From Guatemala City toward El Progreso, there were 32 landslide areas as far as Kilometre 29 near the town of El Chato and a total of 54 landslide zones in the first $48 \mathrm{~km}$ on this main highway toward the Atlantic Ocean. A landslide zone consists of one to three large landslides obstructing the highway.

On this road there were two bridges that suffered considerable damage. The Agua Caliente Bridge collapsed and impeded traffic, and the Benque Viejo Bridge was on the verge of collapse (Husid and others, this report). Severe landslides occurred also 
TABLE 9.-Casualties and damage, by municipalities-Continued

\begin{tabular}{|c|c|c|c|c|c|}
\hline \multicolumn{2}{|c|}{ Municipality } & \multirow{2}{*}{$\begin{array}{l}\text { Population } \\
25,819\end{array}$} & \multirow{2}{*}{$\begin{array}{c}\text { Deaths } \\
110\end{array}$} & \multirow{2}{*}{$\frac{\text { Injuries }}{300}$} & \multirow[t]{2}{*}{$\%$ Damage } \\
\hline 1. & Solola & & & & \\
\hline 1. & Jalapa & 45,425 & 27 & 254 & $50 \%$ \\
\hline 2. & San Pedro Pinula & 23,846 & 9 & 97 & $25 \%$ \\
\hline 3. & Mataquescuinla & 16,145 & 55 & 122 & $20 \%$ \\
\hline 1. & Sta. Rosa & 14,127 & 40 & 291 & \\
\hline 1. & Alta Verapaz & 43,505 & 15 & 700 & $60 \%$ \\
\hline 2. & Sta. Cruz Verapaz & 3,508 & 3 & 253 & $70 \%$ \\
\hline 1. & Quezaltenango & 65,526 & 14 & 228 & \\
\hline 1. & Aguacataman & 18,492 & & & \\
\hline 2. & San Sehastian Huehuetenango & 7,824 & & & \\
\hline 3. & San Pedro Necto & 11,371 & & & \\
\hline & San Miguel Acatan & 15,011 & & & \\
\hline 5. & Concepcion & 8,102 & & & \\
\hline 6. & Newton & 12,613 & & & \\
\hline 7. & St. Ana Huista & 4,755 & & & \\
\hline 8. & La Libertad & 14,756 & & & \\
\hline 9. & Colotenango & 9,458 & & & \\
\hline 10 & San Gaspar Ixchil & 3,058 & & & \\
\hline \multirow{3}{*}{$\begin{array}{l}1 . \\
2 .\end{array}$} & Villa Nueva (Guate) & & 5 & 12 & $8 \%$ \\
\hline & Acatenango (Chimaltenango) & & 22 & & \\
\hline & Total & & 22,525 & 74,027 & \\
\hline
\end{tabular}

along the main highway to the Pacific Ocean, between Guatemala City and Antigua. Landsliding interrupted road traffic along these two main throughways and also disrupted railroads near Las Ovejas, Gualán, El Progreso, Río Hondo, and Puerto Barrios.

The preliminary intensity distribution in Guatemala (fig. 43) suggests that the shaking intensity was greater in the western part of the country. This isoseismal pattern suggests a fault propagation rupture from east to west. The isoseismals broaden to the west, a phenomenon similar to a Doppler effect, which creates a constructive interference pattern to the west. Several small villages were located near and at intermediate distances from the causative fault; for example, adobe construction in Jones, about $8 \mathrm{~km}$ from the fault, sustained no damage. Also, in several communities south of the Motagua fault, such as San Pedro Pinula nearly $25 \mathrm{~km}$ from the fault, adobe construction sustained no damage. Numerous small villages in which adobe buildings sustained no damage were observed 8 to $30 \mathrm{~km}$ from the causative fault. Other towns, such as Entre Rios approximately $37 \mathrm{~km}$ due east of Morales, near the extension of the Motagua fault, had an intensity rating of only $\mathrm{V}$.

The pattern of isoseismals displayed in figure 43 may be the effect of a moving source in the near field. This effect is shown schematically in figure 44 (Benioff, 1955) to be the progression of a discrete number of points. The initiation of the fault motion is near Los Amates, at point 0 , and terminates at point 8 , toward Guatemala City. The largest circle represents a wavelet at point 0 , which in the time domain is shown at the lower part of this diagram and is identified with a 0 , and the succesive circles represent the wavelet position as it propagates from points $1,2,3 \ldots$, and so on. There is a time delay between these points, as is seen in the two lower diagrams. The lower left diagram represents the signal from each point as seen at a station west of the fault, and the lower right diagram represents the signal as seen at a station east of the fault. The composite signal for each direction of propagation is shown as the resultant in the lower part of figure 44 . The energy can be measured as the square of the velocity amplitude; hence, the resultant wavelet traveling to the west, shown at the 


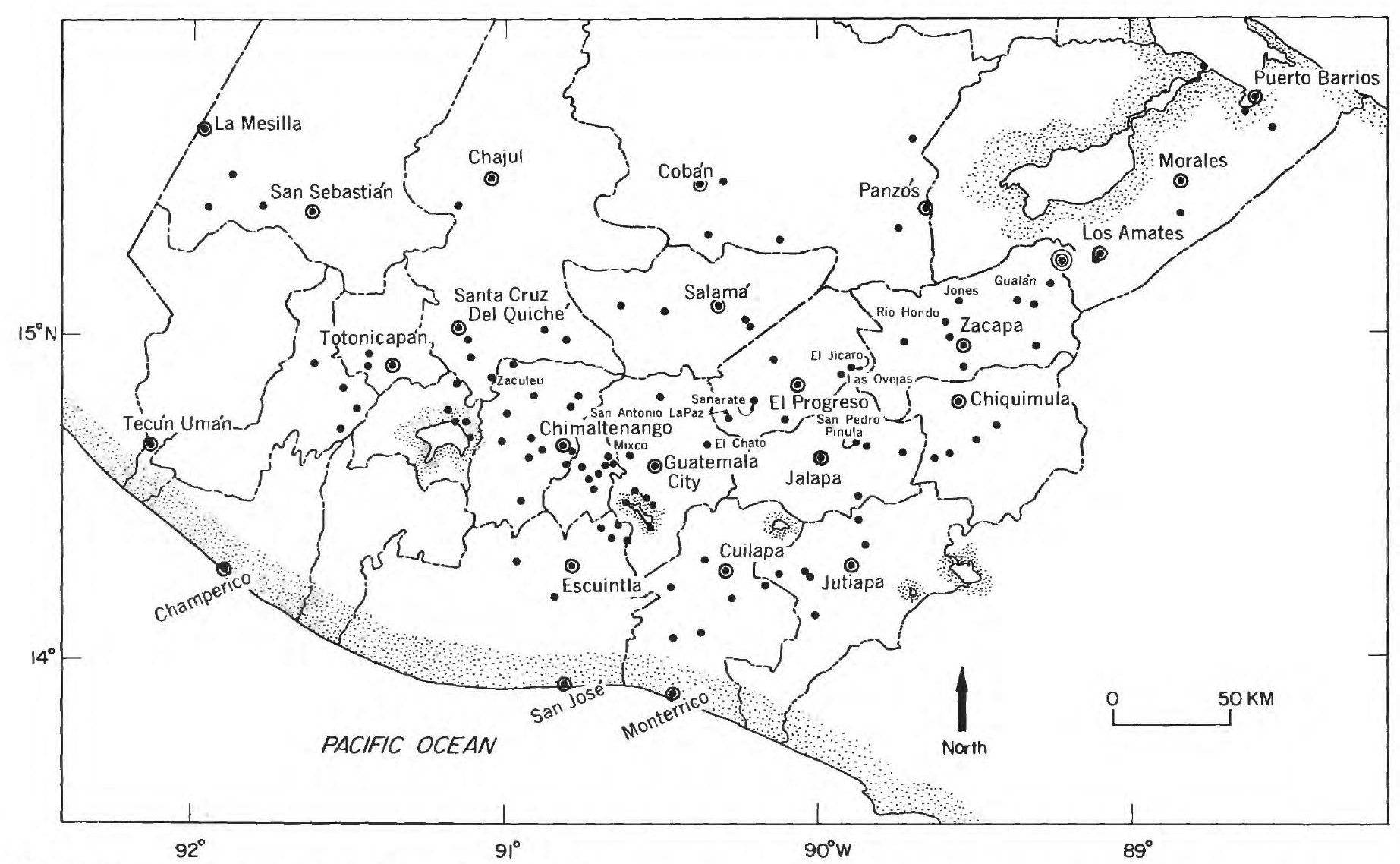

FIGURE 40.- Intensity sampling distribution. Each dot represents the location where one or more questionnaires was completed during a survey taken in Guatemala. Largest circle indicates epicenter location of main event. (Base map modified from Guatemala Instituto Geográfico Nacional, 1974, 1:500,000.)

lower left in figure 44 , has a larger concentration of energy than the slightly dispersed wavelet traveling in the opposite direction.

The possibility of a fault rupture traveling from east to west (suggested in fig. 43) could be verified with teleseismic data at western azimuths. Also, the suggestion of a double rupture or a multiple earthquake from the isoseismal distribution is plausible. If this second alternative is adopted, the first earthquake will be constrained to the observed surface faulting from Los Amates to Kilometre 15 southwest of El Progreso. The second event could be associated with the secondary faulting observed in the Mixco area.

Other factors that may enter into the intensity distribution pattern shown in figure 43 are seismicwave amplification effects, topographic seismicwave amplification, influence of the surficial soil conditions, and depth of the water table.

The high-level isoseismals VI, VII, and VIII represent the shape of the radiation pattern in the near field, assuming the rupture started near the epicentral region and propagated west. A similar suggestion made by Hanks (1975) correlates the intensity VI and VII isoseismals from the San Fernando earthquake with the radiation pattern for 8-s Rayleigh waves and also with the azimuthal variations of the amplitude ground displacements.

The isoseismal map was plotted on a 1:500,000 geologic map of Guatemala (edition by Bonis, Bohnenberger, and Dengo, 1970), and no simple correlation was found between the gross surficial geology and the intensity distribution. There is a correlation between the fault that slipped during the February 4 earthquake and the intensity distribution. West of Guatemala City is the Mixco fault, which has a north-south trend. In this region, the intensity rating attains a maximum of IX.

The earthquake was felt by nearly everyone over an area of at least $93,125 \mathrm{~km}^{2}$, suggesting that an intensity $\mathrm{V}$ or higher extended over that area. The areas felt for intensities VI and higher are given in table 10. 


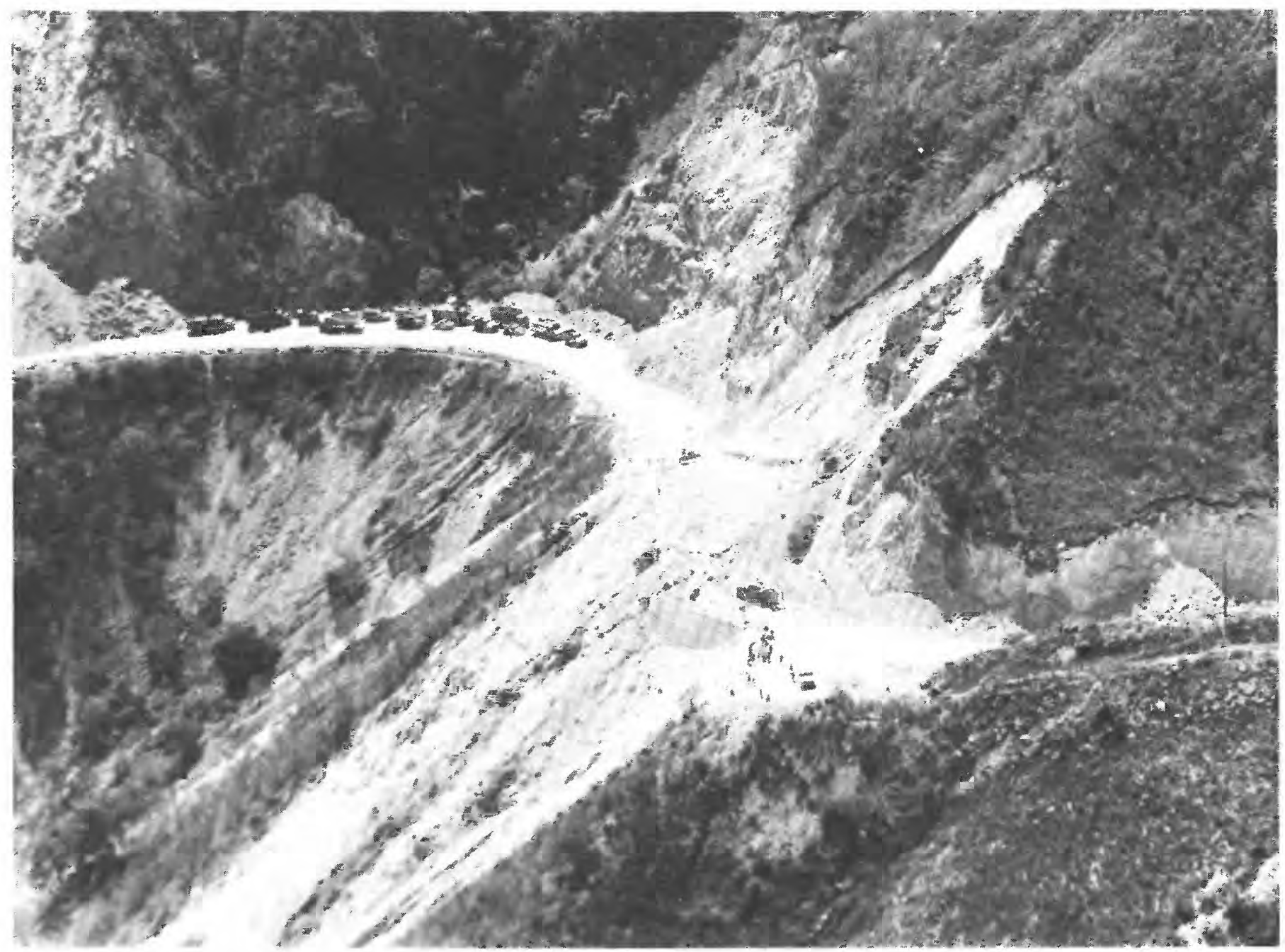

Figure 41. - One of the many landslides obstructing the main highway from Guatemala City toward El Progreso.

TABLE 10.-Felt area for Modified Mercalli intensities VI and higher

\begin{tabular}{lc}
\hline \multicolumn{1}{c}{ Modified Mercalli intensity } & Felt area $\left(\mathrm{km}^{2}\right)$ \\
\hline VI and higher & 32,697 \\
VII and higher & \\
VIII and higher & \\
IX (small area) & \\
\hline
\end{tabular}

\section{DISTRIBUTION OF ADOBE DAMAGE}

The map shown in figure 45 represents the overall distribution of adobe damage in the Republic of Guatemala. This map was prepared with information from a variety of sources. First, we studied reports from the Comite Nacional de Emergencia, which gathered a large amount of information through the local committees. These reports were supplemented by detailed lists of damage and by our assessment of the sustained damage in the field. Newspaper clippings from the national press were also consulted. Other sources of information were gathered by the Universidad de San Carlos and by a team of the Camara de Construccion in Guatemala City.

The adobe damage distribution map shows the amount of damage to a given village. On this map, a scale of 4 means that 91 to 100 percent of all the adobe houses in a village collapsed (fig. 46); a 3 implies 76 to 90 percent; a 2 means 51 to 75 percent; 1 means 26 to 50 percent; 0 in the scale implies negligible to 25 percent damage to adobe houses. The maximum adobe damage was found in

FigURE 42.-A, Rails bent in Gualán, Department of Zacapa. $B$, Rails repaired between El Jicaro and Las Ovejas, Department of El Progreso; also shown in $B$ is the surface faulting with an east-west trend. This photograph was taken from a helicopter in a eastward direction. $C$, Raild bent on the Puerto Barrios wharf. $D$, Aerial view of fault trace near Las Ovejas. See figure 40 for town locations. 


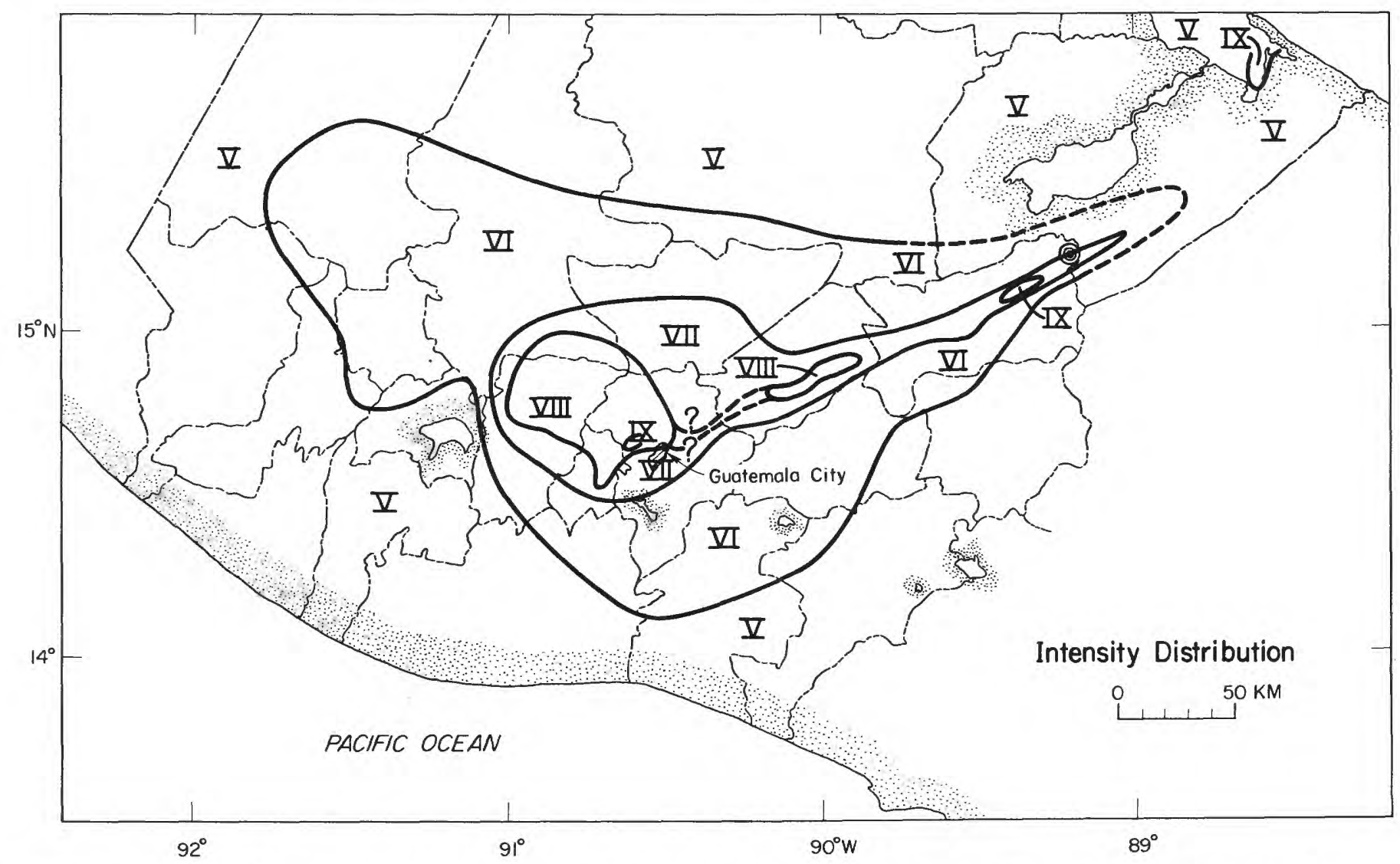

FIGURE 43.-Modified Mercalli intensity distribution in Guatemala from the main event. Circle indicates epicenter location of the February 4 earthquake; dashed line indicates approximate isoseismal. (Base map modified from Guatemala Instituto Geográfico Nacional, 1974, 1:500,000.)

the Departments of Chimaltenango, Guatemala, and lower Quiché. These regions of the country are the highlands of Guatemala. The affected region of 51to 100-percent damage covers a surface area of approximately $8,725 \mathrm{~km}^{2}$. There are two well-defined areas of maximum damage; one follows a trend parallel to the Motagua fault located in the Departments of Izabal, Zacapa, and El Progreso. A gap is found between the 4 and 2 contours for nearly 40 $\mathrm{km}$. Within the next $35 \mathrm{~km}$ there is another concentration of high damage (fig. 45). The damage pattern diminished rapidly to the west into the state of Totonicapán.

TABLE 11.-Damage to adobe-type structures

\begin{tabular}{|c|c|c|}
\hline Scale ${ }^{1}$ & $\begin{array}{l}\text { Percent } \\
\text { damage }\end{array}$ & $\begin{array}{c}\text { Damage } \\
\text { area } \\
\left(\mathrm{km}^{2}\right)\end{array}$ \\
\hline $\begin{array}{l}2 \text { and higher } \\
3 \text { and higher } \\
4\end{array}$ & $\begin{array}{l}51-75 \\
76-90 \\
91-100\end{array}$ & $\begin{array}{l}8,725 \\
2,825 \\
1,720\end{array}$ \\
\hline
\end{tabular}

${ }^{1}$ Scale values taken from figure 45.

A number of cracks, fractures, and short fault scarps were found due west of Guatemala City in the Mixco area. Damage decreases more rapidly to the east than to the west of the zone of strongest shaking. The areas damaged for different percentiles of collapsed adobe houses are given in table 11 .

Adobe structures are apt to collapse more easily than bajareque (Husid and others, this report) and wooden-type construction. The latter construction is found throughout the Motagua River Valley in the lowland near the coastal area of Guatemala. In Puerto Barrios and in Santo Tomás, many of the houses are built of wood. The wharf of Puerto Barrios collapsed because of structural failure and possible ground compaction (Ray Wilson, oral commun., 1976) (fig. 47). There was no damage to well-built structures in the port of Santo Tomás, 5 $\mathrm{km}$ south of Puerto Barrios. In the port of Santo Tomás, a number of ground cracks were observed, and ground-level changes of 10 to $15 \mathrm{~cm}$ in the maritime port were due to ground compaction.

Near Puerto Barrios, mud spouts occurred during the main earthquake. The damage in this region to wood-frame and adobe structures was minimal. 

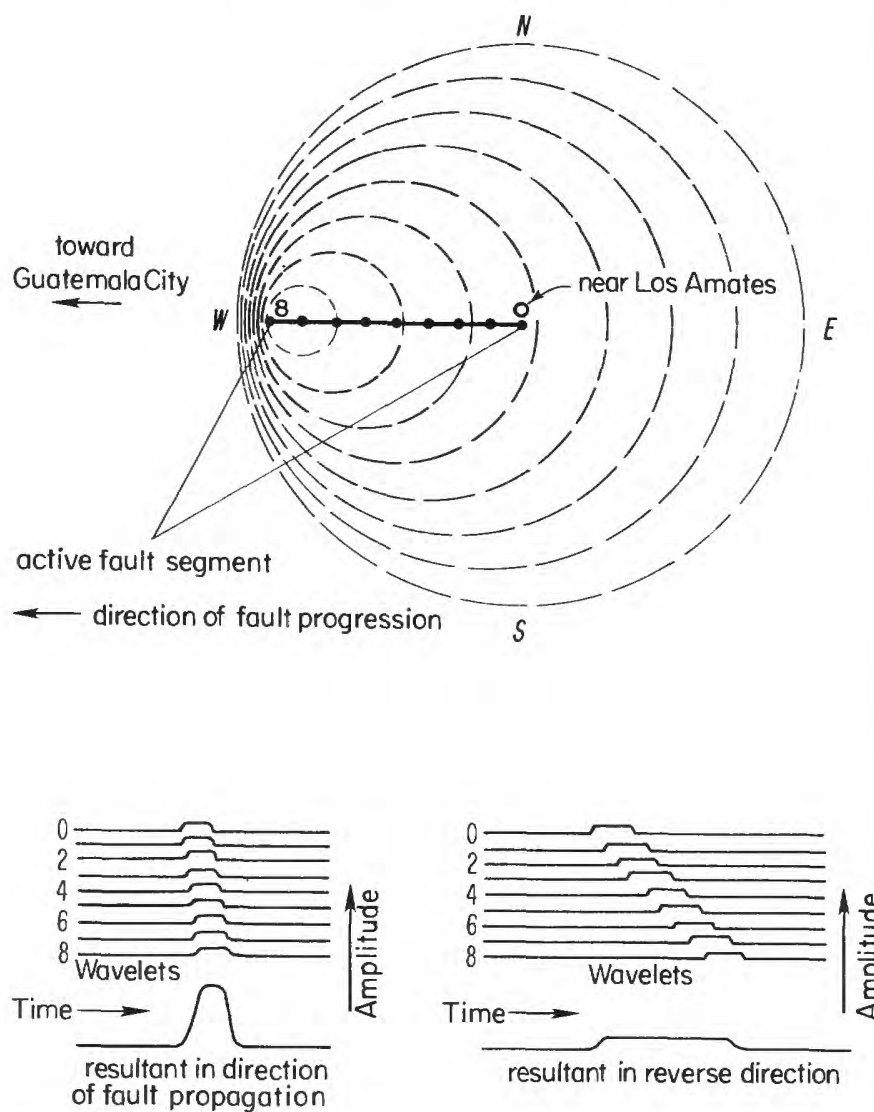

FIGURE 44.- Schematic of slip progression and its effect on wave amplitudes and shapes due to a moving source (modified from Benioff, 1955). Fault propagation from east, near Los Amates, to west, toward Guatemala City.

The pattern of adobe damage (fig. 45) is similar to the intensity distribution shown in figure 43 . The similarity suggests that more energy was released to the west than to the east. It also suggests that seismic energy was released along and near the known fault zone of the Motagua fault. The maximum concentration of damage, mostly in the Department of Chimaltenango, is suggestive of a constructive interference of seismic waves due to a moving dislocation.

\section{INTENSITIES IN GUATEMALA CITY}

The distribution of earthquake intensity was investigated by canvassing Guatemala City in a manner similar to the way in which the Republic of Guatemala was canvassed. In the process of canvassing Guatemala City, data were obtained from a representative number of questionnaires solicited from each of the 16 zones into which the city is divided. A total of 1,050 questionnaires was completed and collected.
A map of intensity distribution for Guatemala City associated with the earthquake is now being prepared. The following cursory comments are the preliminary result of our fieldwork.

The maximum Modified Mercalli intensity in the city was IX, as shown by the partial collapse of reinforced-concrete structures, and there were pockets of high intensities in different zones of the city. A cursory examination of the questionnaires shows that some of the localized high intensities may be related to possible ground-amplification effects of seismic waves. Similar findings were reported elsewhere on a seismic-zonation study in Lima, Peru (Espinosa and others, 1976).

A number of chimneys cracked and collapsed in different suburbs of the city (fig. 48). The variations of the intensity ratings in the city proper varied from VI to IX. A number of wells showed an increase in temperature of more than $2^{\circ} \mathrm{C}$, and their water level changed drastically, sometimes more than $60 \mathrm{~cm}$, due to the February 4 earthquake. In the northern part of the city, damage to adobetype construction was intense. Also, throughout the city, there were a number of damaged reinforcedconcrete structures (Husid and others, this report). A number of landslides occurred to the northwest in the Colonia $1^{0}$ de Julio, Zone 19 , on the Barranco de las Guacamayas. The barrancos have an almost vertical drop of nearly $90 \mathrm{~m}$. Figure 49 shows the head of a landslide in the area, at approximately long $90^{\circ} 33.5^{\prime} \mathrm{W}$., lat $14^{\circ} 40.6^{\prime} \mathrm{N}$.

In Zone 7, 13 Calle B. No. 31-14, a one-story brick house sustained a large amount of damage from a ground crack, possibly a small fault with a northsouth trend, which crossed through the house. This ground crack could be traced very easily through the suburb, across damaged streets and houses. In other zones, such as Zone 19, 8 Avenue No. 6-96 there was considerable damage because of ground failure. In Zone 11, 8 Calle No. 20-62, Colonia Mirador, there was moderate damage to a one-story brick house. These examples show the damage that can be caused by faulting in the immediate vicinity or below some of these houses in Guatemala City.

\section{INTENSITIES IN NEIGHBORING COUNTRIES}

The Modified Mercalli isoseismal $\mathrm{V}$ covered an area from Ilepango, Izales, and San Salvador in El Salvador to Santa Barbara, San Pedro Sula, and Puerto Cortes in Honduras. In Tegucigalpa, an intensity rating of IV was assigned. To the north, 


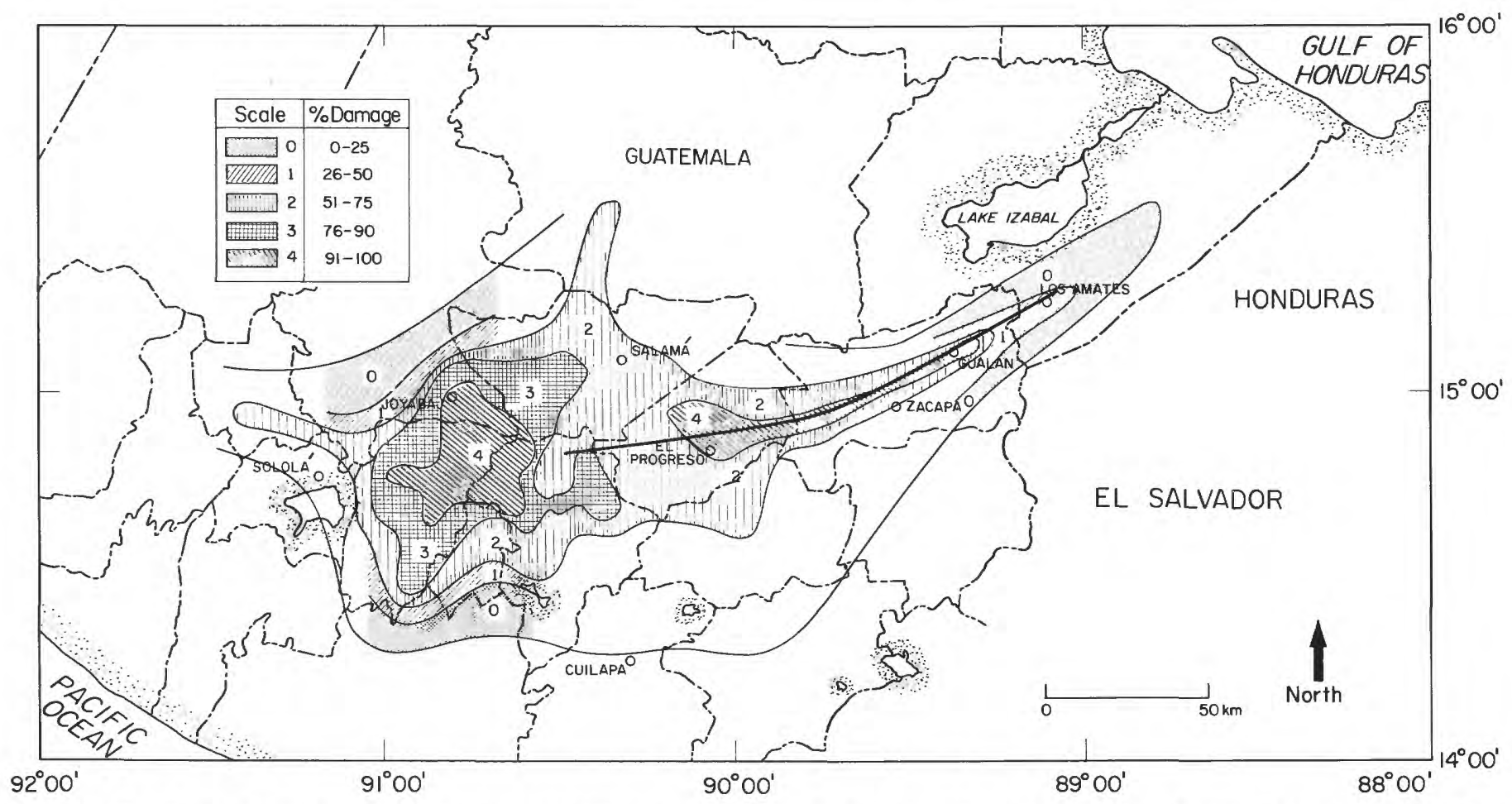

FIGURE 45.-Contour map showing damage to adobe-type structures in Guatemala owing to the February 4 earthquake. See figure 1 for Department names. (Base map modified from Guatemala Instituto Geográfico Nacional, 1974, 1:500,000.)

Belice had a IV and Mexico City a IV rating. Poctun in the Guatemalan northern territory had an intensity of $\mathrm{V}$. The total felt area for an intensity V or higher was $93,125 \mathrm{~km}^{2}$.

The earthquake of 1773 , called the Santa Marta earthquake, caused extensive damage in the Guatemalan highlands down to El Salvador. The February 4 earthquake and the Santa Marta earthquake affected similar areas in Guatemala and El Salvador, but there was no damage to El Salvador from the February 4 earthquake.

\section{GROUND MOTION AT INTERMEDIATE DISTANCES}

Strong ground displacements were recorded on a seismoscope in Guatemala City (Knudson, this report), but, unfortunately, no accelerographs were operational in the area at the time of the earthquake.

Strong ground motions were experienced in the Mixco area, in particular at the Licorera Mixco, where a large oil-fired boiler was displaced horizontally a maximum of $41 \mathrm{~cm}$.

In La Colonia $1^{\circ}$ de Julio, a northwestern suburb of Guatemala City, a large water tank sustained damage to its back bracings at the upper level (nearly $12 \mathrm{~m}$ from the ground). The shear bracings also were bent. The water tank sustained damage at a height of $4 \mathrm{~m}$ from the bottom of the tank and 16 $\mathrm{m}$ from the ground, where the bolts tying the steel walls of the water tank were sheared and water leaked out.

In Guatemala City, in the chemistry building of the ICAITI (see Glossary) complex, a large machine weighing $1,298 \mathrm{~kg}$ was displaced $7 \mathrm{~cm}$ horizontally. To the southeast of the city in Zone 10, in the Herrera's grounds, four medium-sized marble statutes were thrown $40 \mathrm{~cm}$ from their stands (fig. 50). There were some reports that hanging lamps dented the ceilings of homes and that outside hanging lamps left a fan of dents on the walls.

In the maritime port of Santo Tomás, a large upright unloading cargo crane weighing 60 tons was displaced from its rails $5 \mathrm{~cm}$ in a northeasterly direction. This port is northeast of Los Amates.

\section{SOURCE PARAMETERS FROM FIELD OBSERVATIONS}

Many major earthquakes have occurred in close association with major faults; as a result, a number of empirical relations that correlate magnitude, length of surface faulting, fault displacement, and magnitude have been derived. King and Knopoff (1968) developed the following relation:

$$
\log L \bar{u}^{2}=2.24 \mathrm{M}-4.99 \text {. }
$$




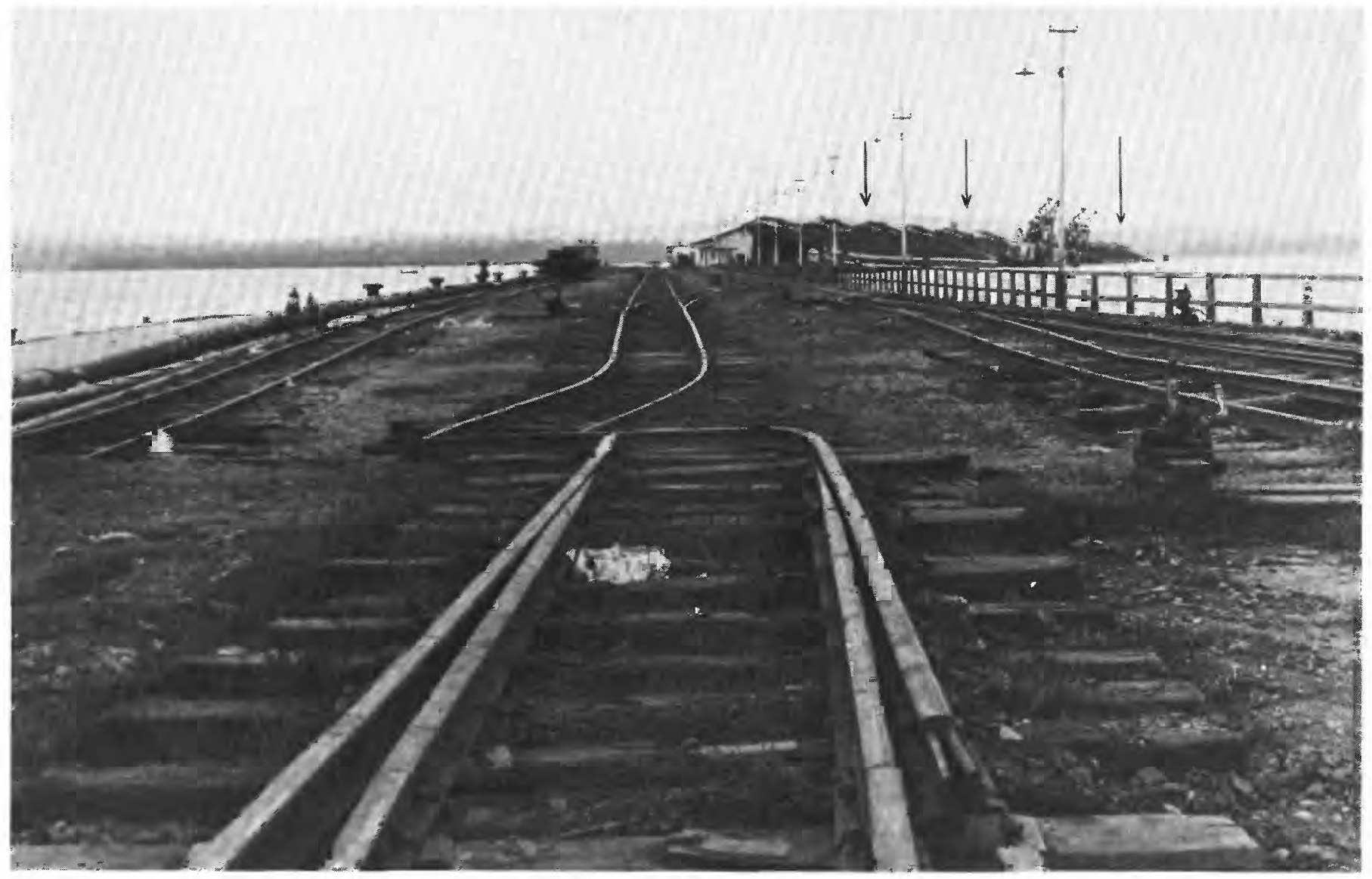

Figure 47.-Puerto Barrios wharf, Department of Izabal, destroyed by February 4 earthquake. Arrows show large warehouse partially submerged. See figure 40 for location of town.

one obtains an $\mathrm{M}_{\mathrm{S}}$ value of 7.4. These values are in good agreement with the value $\mathrm{M}_{\mathrm{S}}=7.5$ determined for the Guatemalan earthquake from teleseismic observations (Person and others, this report).

Having established that $\mathrm{M}_{\mathrm{S}}=7.5$ is a reasonable estimate for this earthquake, we proceed to determine the seismic energy, $E_{\mathrm{S}}$, from the GutenbergRichter energy-magnitude relationship given by Richter (1958) :

$$
\log E_{S}=11.8+1.5 \mathrm{M}_{\mathrm{s}} .
$$

This equation yields $E_{\mathrm{S}}=1.1 \times 10^{23} \mathrm{ergs}$ for the Guatemalan earthquake of $\mathrm{M}_{\mathrm{S}}=7.5$.

The stress drop (Keilis-Borok, 1959; Aki, 1966; Brune, 1970, eq. 30) is defined by

$$
\Delta \sigma=\frac{\mu \bar{u}}{r} \frac{7 \pi}{16}
$$

where $r$ is the radius of a circular dislocation, assumed in this case to be $150 \mathrm{~km}$, the rigidity representative of volume around the faulted area is

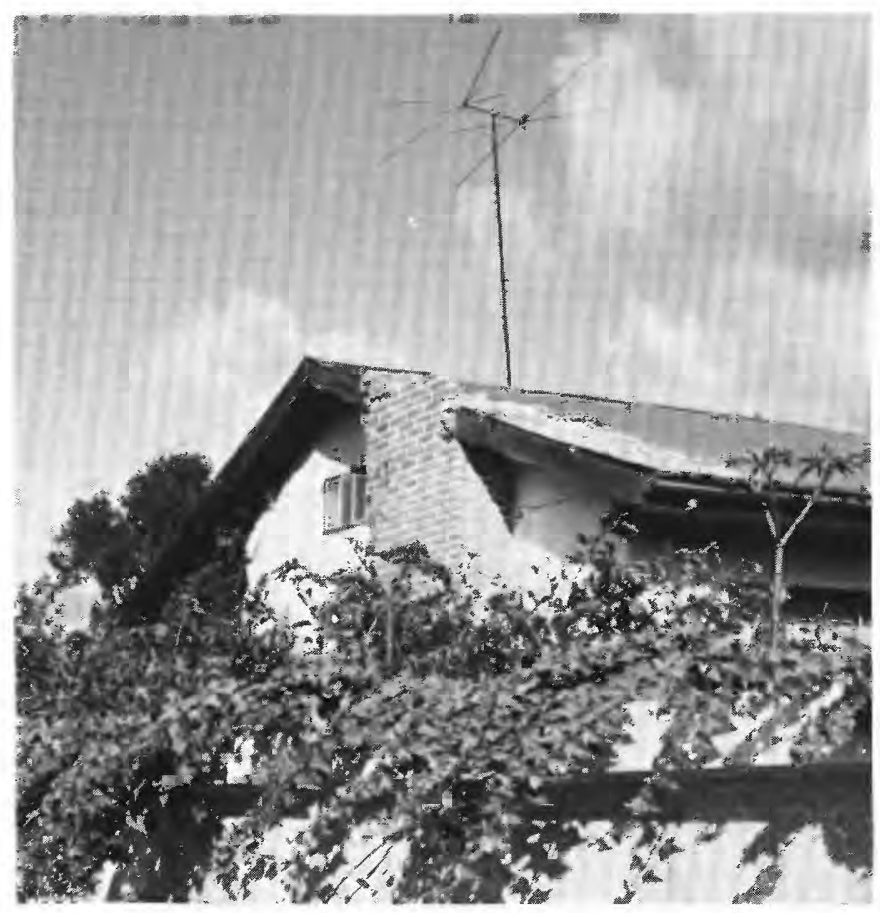

FIgure 48.-Chimney collapse from a one-story house in Guatemala City, Zone 11. 


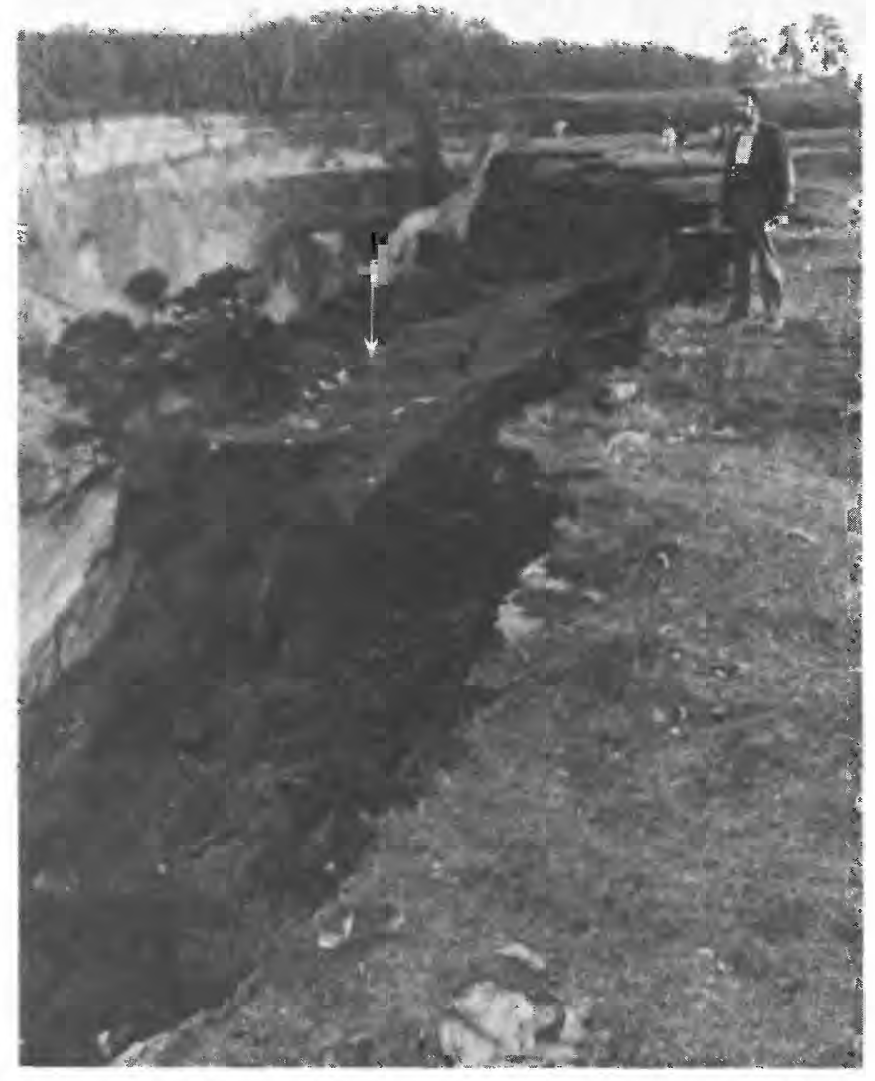

Figure 49.-Head of large landslide (shown by arrow) in the Barranco de las Guacamayas, Guatemala City.

assumed to be $\mu=3 \times 10^{11}$ dyne $\mathrm{cm}^{-2}$, and $\bar{u}=100 \mathrm{~cm}$; then,

$$
\Delta \sigma=3 \text { bars. }
$$

To verify the above stress-drop determination, the seismic moment $M_{0}$ and the energy $E$ (Brune, 1968), defined by

$$
M_{0}=\mu \bar{u} \mathrm{~A}
$$

and

$$
E=\sigma \bar{u} A,
$$

are combined to obtain $\sigma$

$$
\sigma=\frac{\mu E}{M_{o}} .
$$

Assuming $\mu$ and $\bar{u}$ as given above and $A$, the dislocation area, to be $300 \mathrm{~km}$ in length and $20 \mathrm{~km}$ in width (assumed, Brune, 1968, table 2), $M_{0}=1.8 \times 10^{27}$ dyne-cm. Using $E$, determined from equation (3)

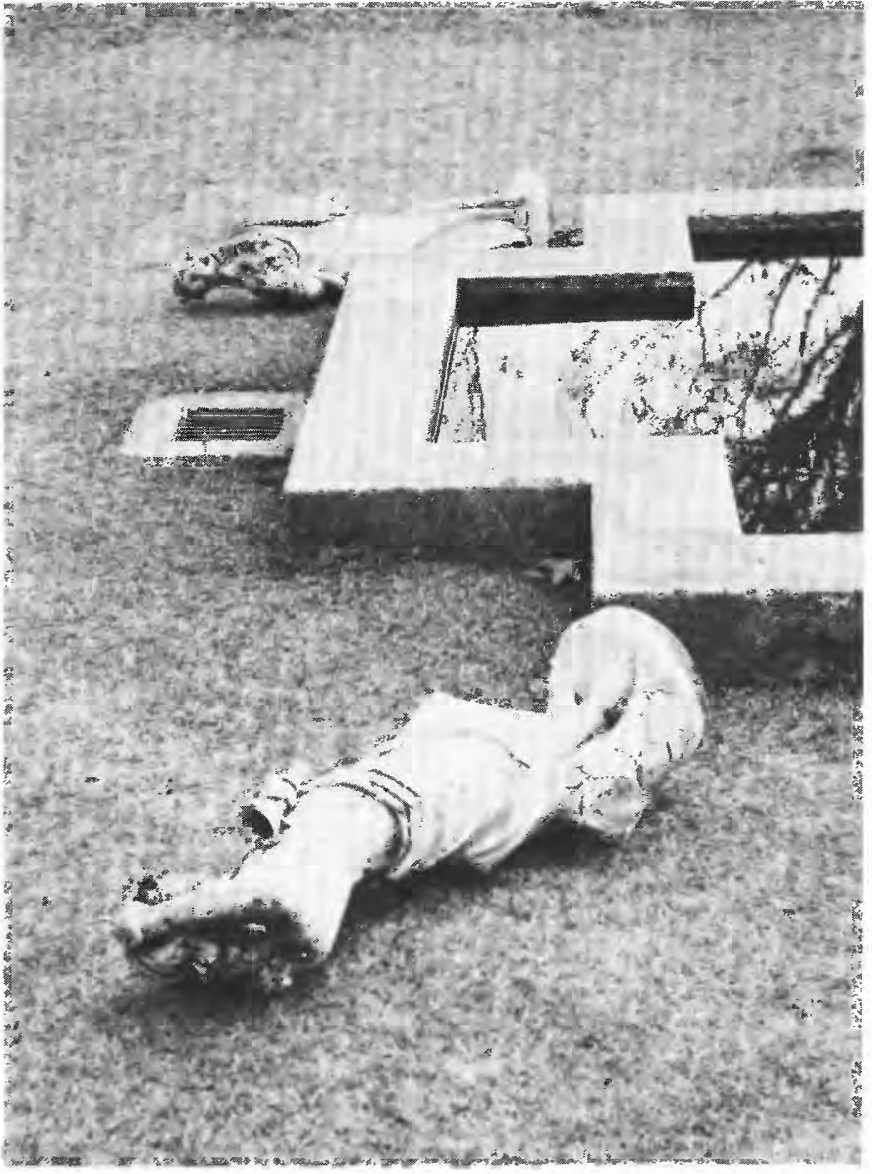

FIGURe 50.-A marble statue thrown $40 \mathrm{~cm}$ from its pedestal; it is $120 \mathrm{~cm}$ high, weighs approximately $200 \mathrm{~kg}$, and is located in Zone 10 in Guatemala City.

to be $1.1 \times 10^{23} \mathrm{ergs}$, and substituting these values in equation (7), one obtains $\sigma=18$ bars.

From the above computations, it seems that the February 4 earthquake was a low-stress-drop earthquake. Independently, Dewey and Julian (this report) have found $\Delta \sigma=6.6$ bars, using information determined from the spectral density of G-waves.

Using a Modified Mercalli intensity rating of VII for Guatemala City with an epicentral distance of $157 \mathrm{~km}$, one determines the particle horizontal velocity (Espinosa, unpub. data, 1975) from

$$
\log \dot{x}=1.27-0.79 \log \Delta+0.16 I_{\mathrm{mm}}
$$

to be $4.5 \mathrm{~cm} / \mathrm{s}$, where $\Delta$ is the epicentral distance in kilometres and $I_{\mathrm{mm}}$ is the Modified Mercalli intensity rating. If, instead of the epicentral distance, one uses the distance from the causative fault to Guatemala City $(25 \mathrm{~km})$, then one obtains a maximum particle velocity of $19.3 \mathrm{~cm} / \mathrm{s}$. The above quantities give an indication of the level of ground motion of the main event experienced in Guatemala City. 
An earthquake similar to the Guatemala earthquake was the Varto-Üstukran earthquake of August 19, 1966, on the Anatolian fault system in Turkey (Ambraseys and Zátopek, 1968; Wallace, 1968), and data obtained from it are very similar to the observations made by the authors after the Guatemalan earthquake. These two earthquakes are strike-slip faults, the former right-handed and the latter left-handed. In terms of fault displacement, magnitude, and length of faulting, the February 4 earthquake is similar to the November 26, 1943, Turkish earthquake, which had a magnitude of 7.6, a length of rupture of $280 \mathrm{~km}$, and a relative horizontal displacement of $110 \mathrm{~cm}$. The February 4 earthquake had a magnitude of 7.5, a length of rupture of $240 \mathrm{~km}$, and an average relative horizontal displacement of $100 \mathrm{~cm}$. 
THE GUATEMALAN EARTHQUAKE OF FEBRUARY 4, 1976, A PRELIMINARY REPORT

\title{
DAMAGE AND ENGINEERING IMPLICATIONS
}

\author{
By Raul Husid, Alvaro F. Espinosa, and Antonio Quesada ${ }^{5}$
}

\section{INTRODUCTION}

In this report, we discuss the damage done by the February 4 earthquake and the engineering implications in greater detail. We report on the damage to selected structures in the capital city and on a few structures in the rest of the affected area but do not attempt to include all the important failures.

\section{EARTHQUAKE-RESISTANT DESIGN PRACTICE IN GUATEMALA}

When the February 4 earthquake occurred, no earthquake-resistant-design code had been enacted into law in Guatemala, and therefore it was not mandatory to design structures to withstand seismic forces. Each engineer or architect selected a foreign code and designed accordingly (J. Asturias, oral commun., 1976). The same professional was usually in charge of supervising the construction process. Review of design and construction by specialized structural engineers, independent of the original designer, was not required, as it is in Chile, Mexico, and the United States.

According to two local structural engineers, J. Arias and R. Zepeda (oral commun., 1976), many professionals used elements of a version (not necessarily the latest) of the Structural Engineers Association of California code. Thus, the structures in Guatemala City were not designed according to common standards. In the short time available for the study, it was difficult to assess, from the condition of the buildings, whether the various standards employed are suitable for the local soil conditions, quality of construction materials, dynamic characteristics of the structures, and other important factors. It is noteworthy to mention that the material characteristics, such as the strength of steel reinforcing bars, are frequently assumed by the engineer without any supporting technical evidence.

\footnotetext{
5 Organization of American States, Washington, D.C.
}

\section{TYPES OF STRUCTURES}

Guatemala City has many modern buildings; most are reinforced concrete, but a few are high-rise steel structures. The predominant type of modern construction appears to be the reinforced-concrete frame structure having flat beams in one or two directions and masonry (reinforced or unreinforced) filler walls. It is common to find filler walls made of poorly reinforced hollow brick or hollow tile.

One of the most common forms of construction is adobe, which is used for the majority of houses, churches, and small structures throughout the country. Roofs are generally tile on wood-pole rafters.

Reinforced mud or bajareque construction is also used extensively in Guatemala. It consists of a wood frame covered with lath, the wall space being filled with mud and plastered. Bajareque is similar to quincha, which is frequently used for building houses in the coastal region of Peru. Quincha construction sustained extensive damage in the 1970 Peruvian earthquake (Husid and Gajardo, 1970; Berg and $\mathbb{H} u s i d, 1971,1973$ ).

Wooden construction was common in Puerto Barrios and in the port of Santo Tomás. Corrugatedsteel and reinforced-concrete grain silos were used in the area affected by the earthquake. Water tanks were predominantly elevated and built of reinforced concrete or steel.

\section{DAMAGE SURVEY}

Although the capital city was not damaged as severely as towns along the Motagua River Valley and some towns in the highlands west of Guatemala City, there was extensive damage in several zones, and some reinforced-concrete and steel structures completely collapsed.

The types of construction found outside Guatemala City are adobe, bajareque, and wood. Adobe construction in many towns sustained the same 


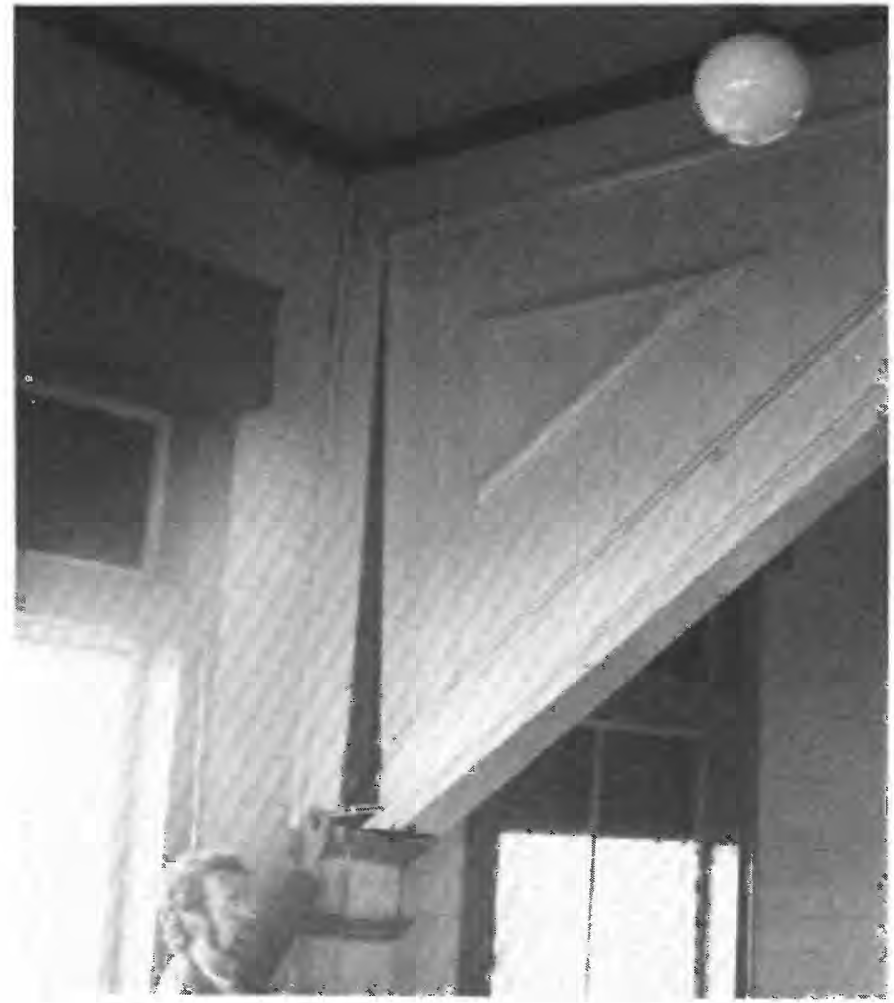

Figure 51.-Damage to a wooden structure in Puerto Barrios, caused in part by ground compaction. Note the large offset of $11 \mathrm{~cm}$ shown in the photograph.

heavy damage that has been observed after many previous earthquakes in other countries (Husid and Gajardo, 1970; Eisenberg and others, 1972; Husid and Espinosa, 1975; Espinosa and others, 1975). Wooden construction withstood damage well even when extensive damage was caused by ground compaction (Ray Wilson, oral commun., 1976) beneath the building (fig. 51).

Many school buildings were severely damaged by this earthquake, and, if the earthquake had occurred during class time, the death toll would have been larger. The second story of a three-story reinforcedconcrete frame structure with masonry walls at the Colegio San Javier collapsed (fig. 52). In the same school complex, a second building, next to the one that partially collapsed, was extensively damaged. There was no available information about the lateral loads used in the design of the school structures.

The Instituto Guatemalteco Americano, a fivestory reinforced-concrete frame structure with poorly reinforced hollow brick walls sustained extensive damage. This structure has rather large cantilevered slabs in its perimeter supporting very heavy concentrated loads (reinforced-concrete orna-

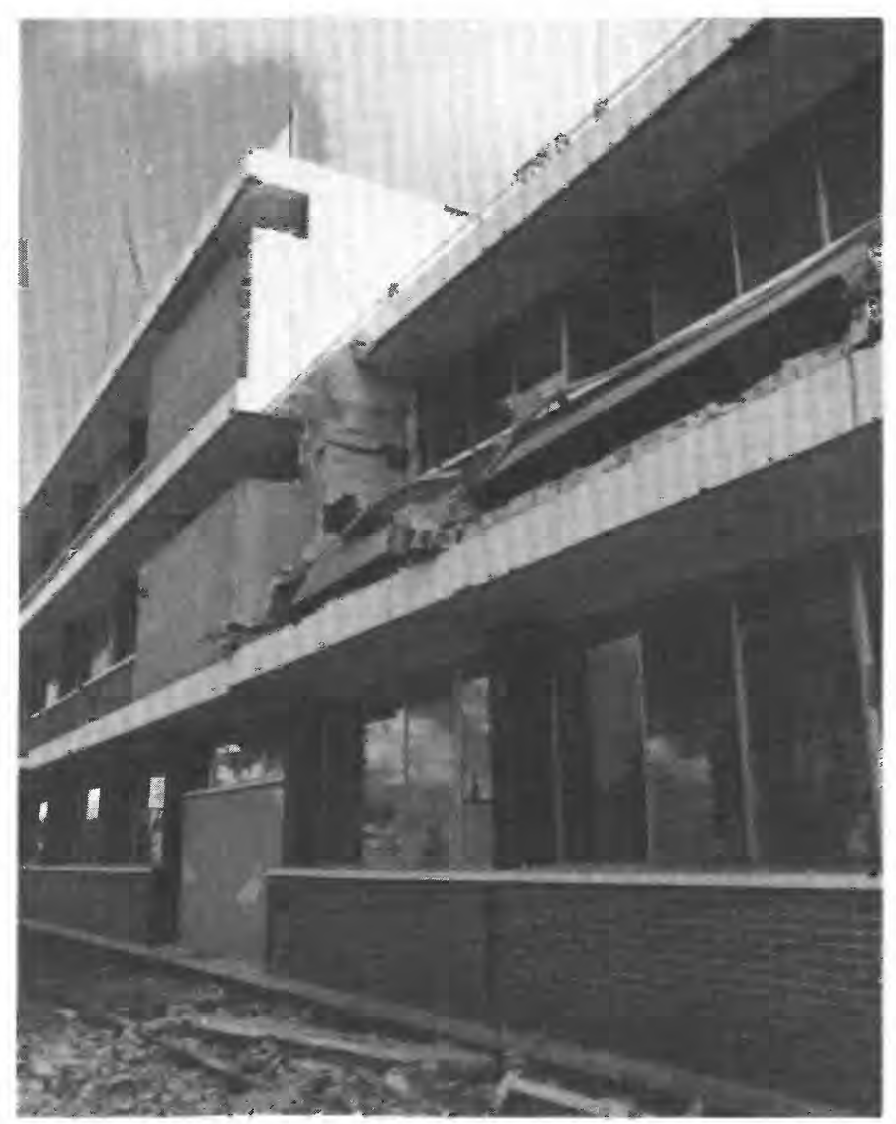

Figure 52.-Collapse of the second story of a building at the Colegio San Javier (Zone 12), Guatemala City.

ments and hollow brick walls) at their free end. Most of the walls were on the verge of collapse, and the slabs showed severe cracks in the cantilevered area. A slab on the penthouse partially collapsed, and reinforced-concrete columns and beams showed severe damage at the same level. It is important to note that this school building, which sometimes houses more than 2,000 students, has only one stairway. If the earthquake had occurred when 2,000 students were attending classes, many could have been injured as a result of panic and lack of adequate exits.

A three-story framed reinforced-concrete structure (fig. 53) was partially collapsed (Zone 12) when columns on its second floor failed.

Severe damage to several hospitals in Guatemala City created a serious problem because of the large number of injured people therein. Included were the Hospital Neuro-Psiquiátrico (Zone 7), Sanatorio San Vicente (Zone 7), Hospital Roosevelt (Zone 11 ), and the Nursery School of Casa del Niño No. 1 (Zone 1).

The Cathedral of Guatemala City, which was partially destroyed during the 1917-18 earthquakes 


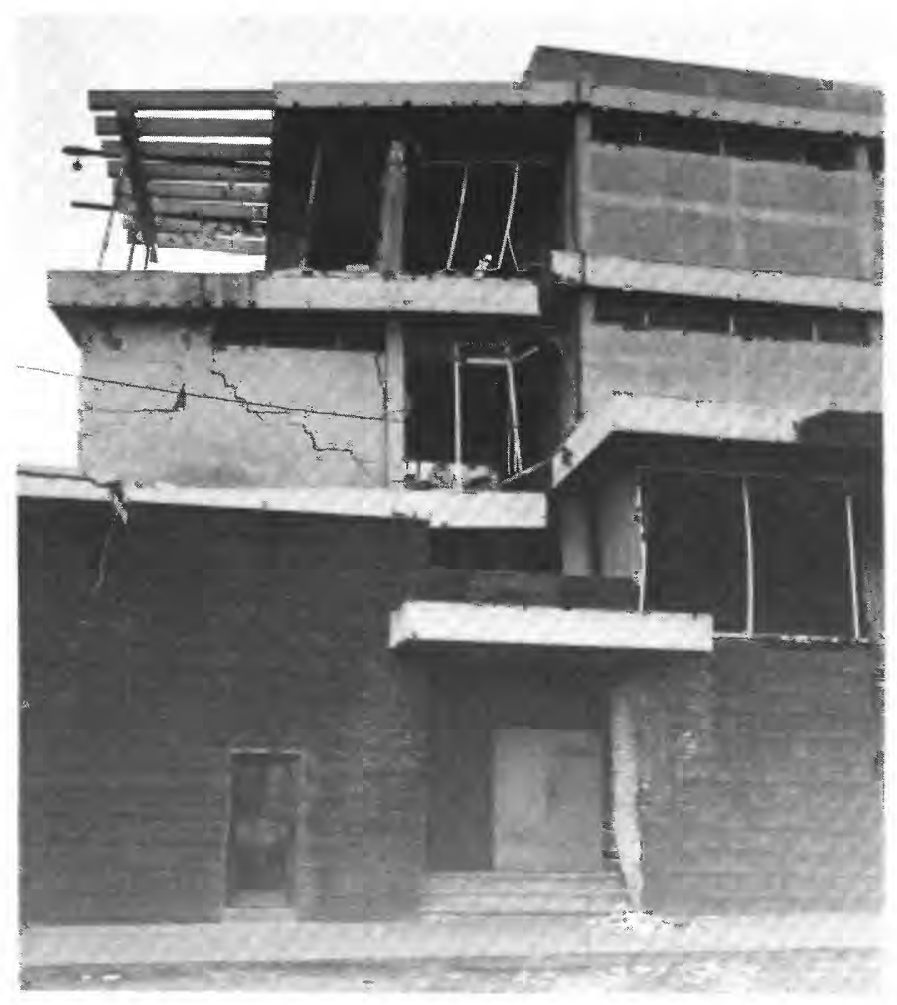

FIGURE 53.-Partial collapse of a three-story reinforced-concrete structure due to failure of columns in its second floor (Zone 12), Guatemala City.

(Penney, 1918; Seismological Society of America Bulletin, 1911-1975, vol. 8, no. 1, p. 38-39), was extensively damaged, and both front towers were on the verge of collapse.

A new church, Iglesia del Divino Redentor (fig. 54), sustained extensive damage, including collapsed roof and walls (Zone 11). The roof was supported from the bottom chord of steel trusses that failed and caused the collapse of the walls. The overlapping of vertical steel bars was done at the same level, and the separation of ties contributed to the weakness of the structure. Other churches were also seriously affected in Guatemala City, and some were completely or partially collapsed.

The Hotel Terminal (Zone 4), a reinforced-concrete frame, flat-slab, six-story building, collapsed when several columns at the third floor failed (fig. 55). Simple ties were used, and they were widely spaced. This column failure appears to be similar to failures seen in the upper story of the Student Union Building of the Universidad Agraria Nacional in Lima, Peru, after the October 3, 1974, earthquake (Husid and others, 1976).

Numerous gas-station structures, designed in the form of inverted pendulums, collapsed when the welding failed (fig. 56).
The International Airport building sustained minor damage, and, in one area, ground compaction occurred beneath the western part of the structure. An inspection of the airport building was made at the request of the airport commander. The two side concourses (fingers) off the main structure were designed as two-story inverted-pendulum-type structures. These fingers had one stair exit, a severe hazard in case of fire or earthquake.

Various elevated steel water tanks collapsed in Guatemala City and vicinity. Figure 57 shows one type of tank that suffered complete failure. Figure 58 shows the engineering plan of another type of elevated steel water tank (50,000-gallon capacity) that was used extensively throughout the city and failed in several locations. Three water tanks of this design that were full of water at the time of the earthquake collapsed (fig. 59). Two other tanks of this design that were empty sustained extensive damage; the anchor bolts had sheared, and most of the diagonal bracing failed.

A few corrugated-steel grain silos collapsed (fig. 60 ), and some that remained standing sustained extensive damage where they were connected to the foundation.

An inspection was made of the XAYA-PIXCAYA project, which, when it is completed, will provide water for Guatemala City. The sedimentation tank and the Plant Lo De Coy are located near Mixco. The main event, or possibly its aftershocks, created a new system of fractures that crosses beneath the sedimentation tank and other structures (fig. 61). These fractures may be related to renewed movements on an old fault. The existence of steep slopes in this area creates a potential for landslides, especially if cracks should develop in the sedimentation tank and water should leak into the ground.

Surface breakage on north- to northeast-striking secondary faulting (Zone 19) in Colonia San Francisco locally generated extensive damage to local residences (fig. 62).

In San José Rosario, a subdivision of Guatemala City, surface breakage with both vertical and rightlateral displacement occurred on a secondary fault parallel with the San Francisco fault. This surface rupture was in an area where plans have been made for construction of high-cost new homes (fig. 63).

Three central spans of the Agua Caliente Bridge, about $36 \mathrm{~km}$ northeast of Guatemala City, collapsed, but the piers remained undamaged. The spans were pinned at one end and had rocking rollers at the other. The failure appears to have been generated by the local failure of the supports caused by large 


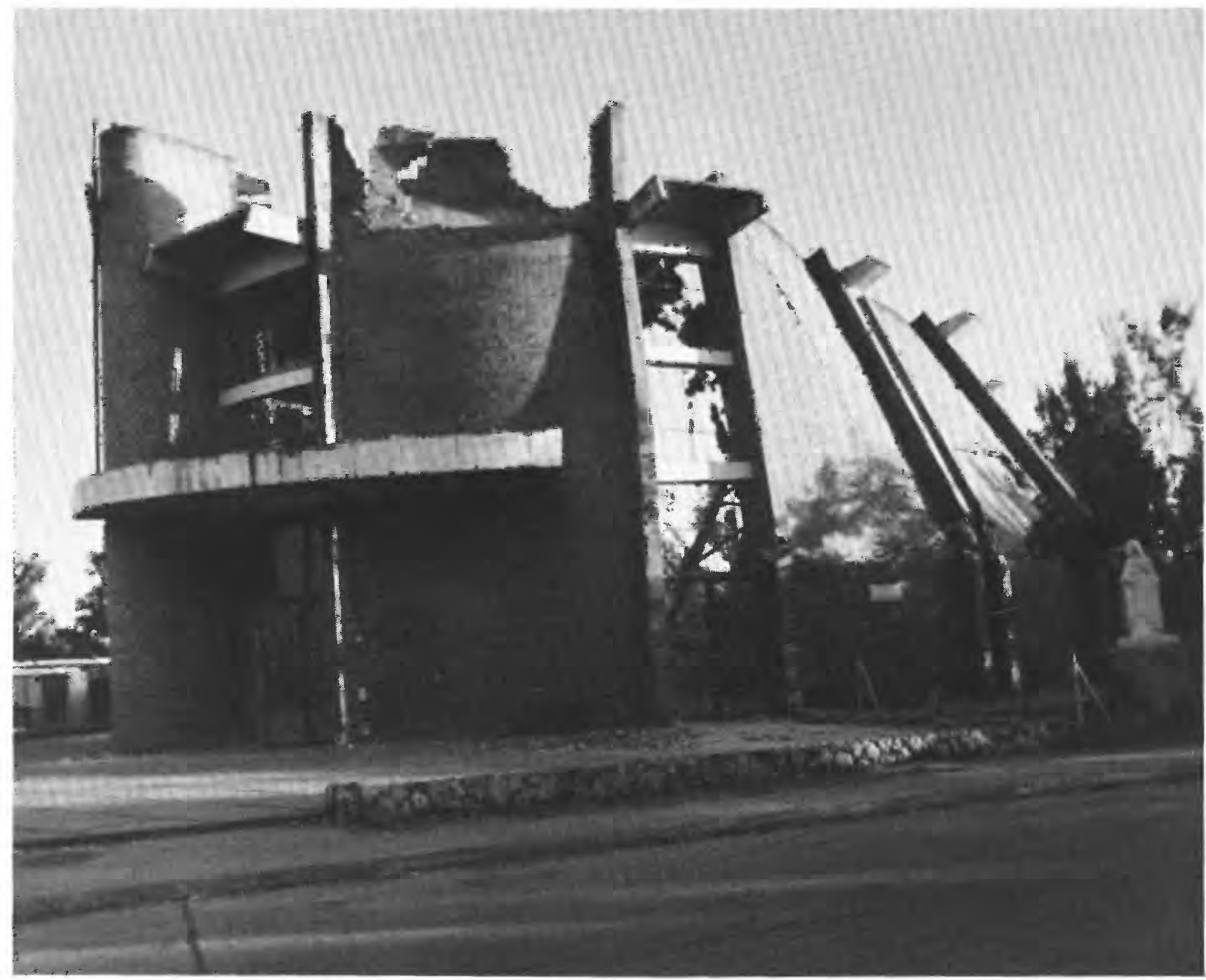

Figure 54.-Collapse of a new church, Iglesia del Divino Redentor, Guatemala City (Zone 11).

displacements of the deck (fig. 64). An old steeltruss railroad bridge near the Agua Caliente Bridge sustained no damage.

The Benque Viejo multiple-span steel-truss bridge across the Platanos River was near collapse because of the large relative displacements between the trusses and their supports. The rollers have snapped flat between the upper and lower bearing plates (fig. 65).

\section{GENERAL OBSERVATIONS}

During the damage survey, it was found that similar problems recurred many times. Some of them are briefly described below.

The use of nonstructural masonry walls in reinforced-concrete framed structures was frequently neglected in the design, as has been observed in previous earthquakes, for example, the 1970 and 1974 Peruvian earthquakes (Husid and Gajardo, 1970; Berg and Husid, 1973; Husid and others, 1976). When lateral displacements occur in structures, resisting elements are loaded in proportion to their stiffnesses. Hence, short columns will be loaded with far greater shear forces than long columns. A column having a free height $H$ has a stiffness approximately eight times greater than that of a column of equal cross section and height $2 H$. Hence, the short column carries a lateral load approximately eight times larger than that carried by the larger column. One of the many examples of this kind of failure observed in Guatemala is shown in figure 66 . 


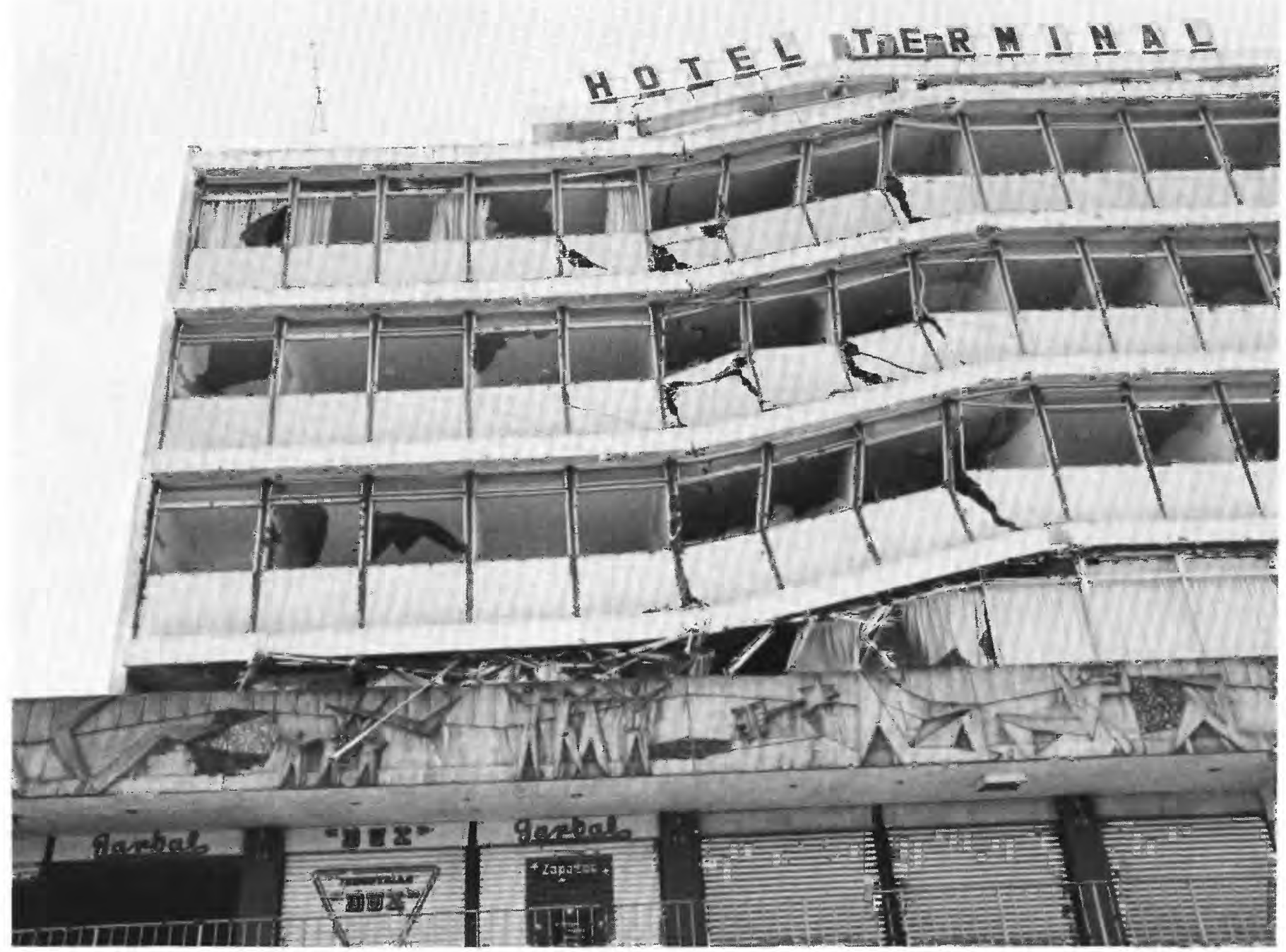

FIgURE 55.-Collapse of the Hotel Terminal, caused by the failure of reinforced-concrete columns in its third story. This building is located in Guatemala City (Zone 4).

The lack of reinforced-concrete columns framing masonry walls has been shown to be responsible for heavy losses during earthquakes. Experimental studies concerning the behavior of masonry walls subjected to lateral loads have shown that, when such walls are designed with integral framing or edge members, their behavior is almost ductile, even after cracking. When the masonry walls are not so framed, their lateral failure is extremely brittle and sudden, even for smaller lateral loads (Jorquera, 1964).

A common practice in Guatemala is to build nonstructural unreinforced masonry walls in tall structures. The behavior of these walls was very poor, as in previous earthquakes. An example is shown in figure 67, where brick falling from the 10th and 11th stories of a building destroyed the slab roof and part of the supporting structure of the first floor. A similar problem was reported by Husid, Espinosa, and de las Casas (1976) at the Industrial Bank of Peru in downtown Lima, after the October 3 , 1974, earthquake.

Several one-story reinforced-concrete framed structures collapsed completely, and the quality of concrete did not seem to be a factor that could justify the failure. It was observed that distances between ties in columns were rather large and exceeded the American Concrete Institute specifications, especially close to the slab and ground levels (fig. 68).

Heavy parapets located in the upper part of front facades, which are severe hazards for the population during earthquakes, collapsed in many areas throughout the capital city. 


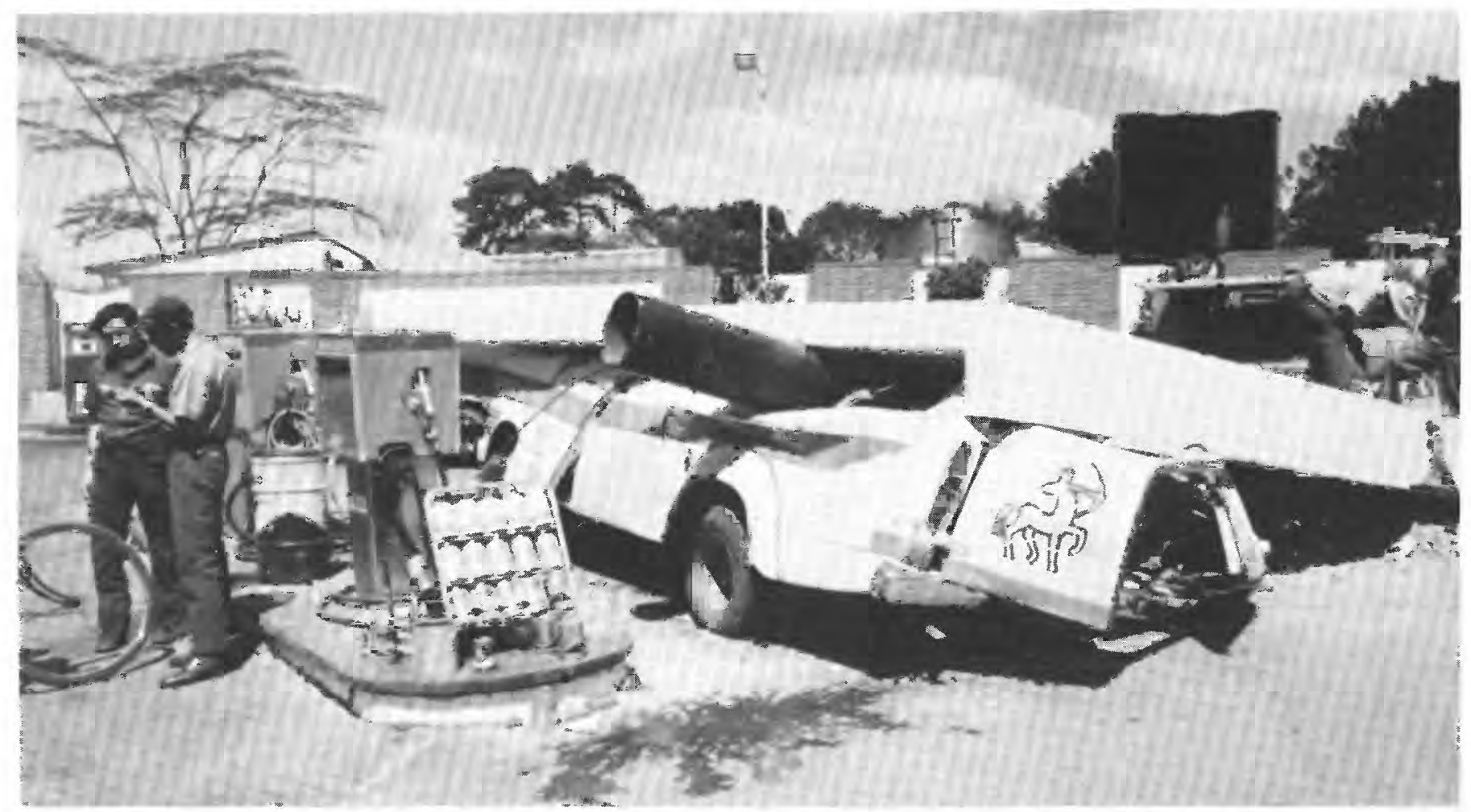

FIGURE 56.-Collapse of inverted-pendulum gas-station structure, Guatemala City (Zone 7).

Although chimneys are not common on homes in Guatemala City because of the mild weather, several of those that did exist collapsed.

Adobe construction is not earthquake resistant; some examples of the unsatisfactory performance of adobe is shown in figures $69 A, B, C$, and $D$. Considering the fact that it is not economically feasible to eliminate adobe construction in Guatemala, it would be desirable to make an inventory of the different types of adobe used countrywide and prepare recommendations for simple modifications that might improve the strength of adobe houses subjected to earthquakes.

A common design for multistory structures in Guatemala City utilizes principal frames in the transverse direction only. The horizontal loads in the longitudinal direction are resisted with a "pseudorigid" frame in which the normal beams are replaced by wide strips of slab (flat beams) that join the tops of the columns. As an example, figure 70 shows a five-story reinforced-concrete structure that sustained serious damage when flat beams were almost destroyed; the building had to be evacuated. Buildings of this design are usually very flexible and have long fundamental periods. It is probable that the behavior of the multistory buildings would have been less satisfactory if they had been subjected to a stronger ground shaking or to shaking of similar amplitude but longer periods.
A close look at the effects of the February 4 earthquake in Guatemala City shows the following aspects :

1. Strengths of reinforced-concrete lateral-loadresisting elements were often unrelated to their stiffnesses.

2. Masonry filler walls in multistory buildings lacked minimum reinforcement.

3. Numerous heavy parapets collapsed and created a serious hazard in Guatemala City.

4. Reinforced-concrete column ties were frequently too widely spaced and sometimes not adequately hooked.

5. Brick walls often lacked reinforced-concrete corner columns, and long walls also lacked intermediate reinforced-concrete columns.

6. Surface breakage on secondary faulting occurred in developed areas.

7. Adobe construction sustained heavy damage. Adobe houses did not have any edge members.

8. Heavy roofs of adobe and unreinforced masonry houses frequently collapsed.

9. Elevated water tanks often failed. From the number of collapses, types of connections, and sizes of resisting elements, it is suspected that the lateral-force seismic coefficient used for the design was too low.

10. Corrugated-steel grain silos frequently failed, and several collapses were observed. 


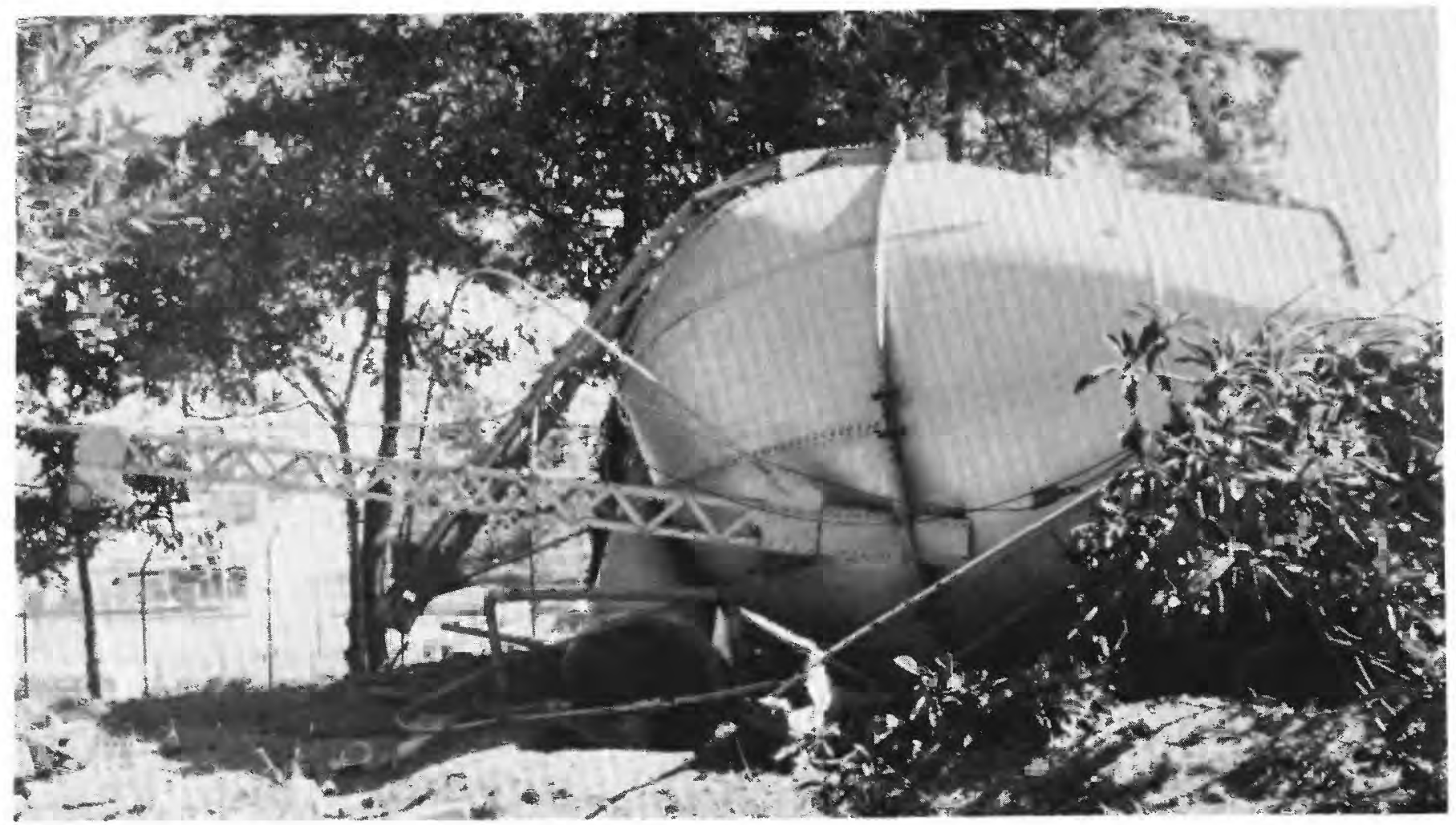

FIGURE 57.-Collapse of an elevated steel water tank in the Instituto Técnico Vocacional in Guatemala City (Zone 13).

Foundation Plant

Tank Cross Section
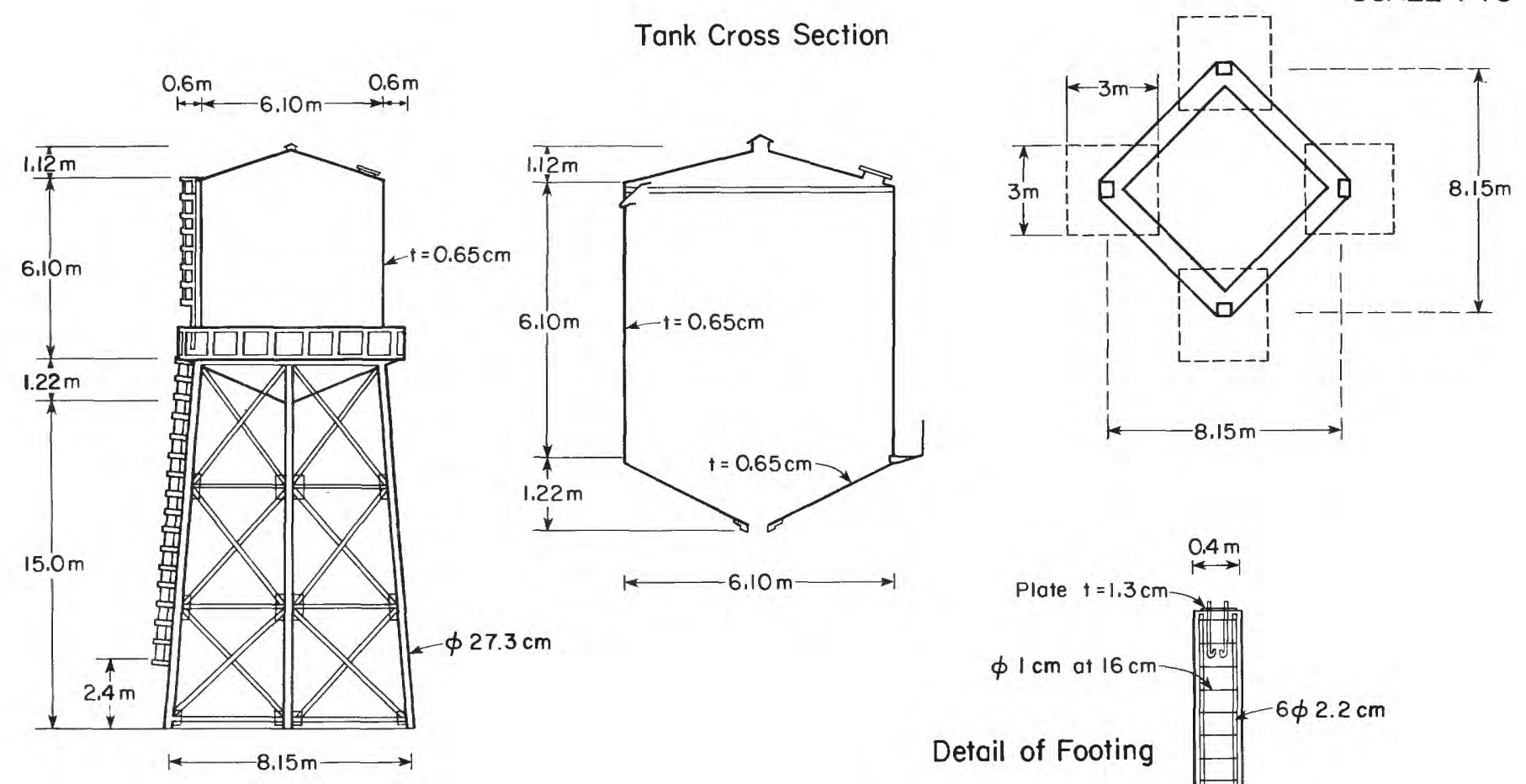

SCALE 1:75

Tank Cross Section 


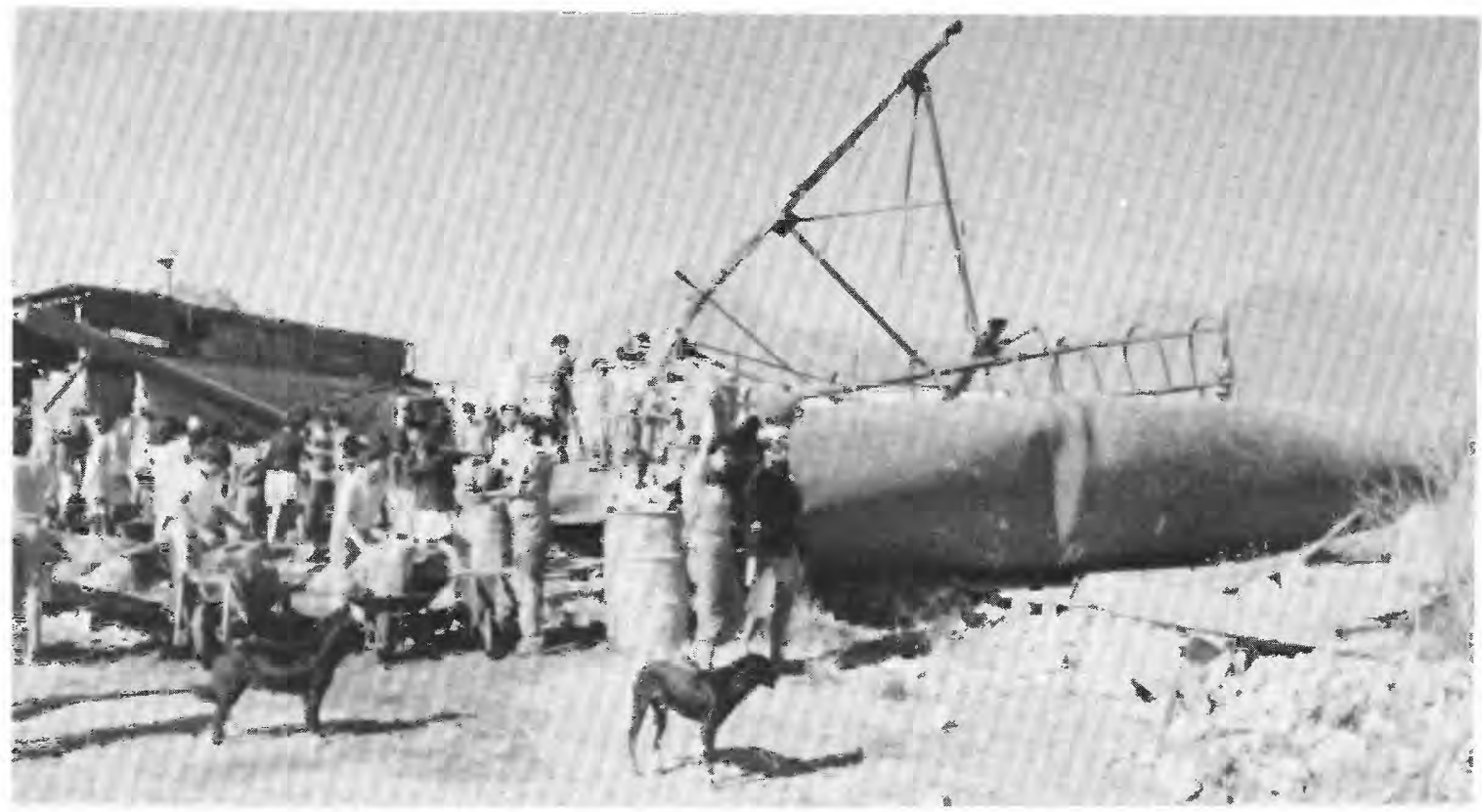

Figure 59.-Collapse of an elevated steel water tank in Villanueva, Colonia de los Planes, $22 \mathrm{~km}$ south of Guatemala City.

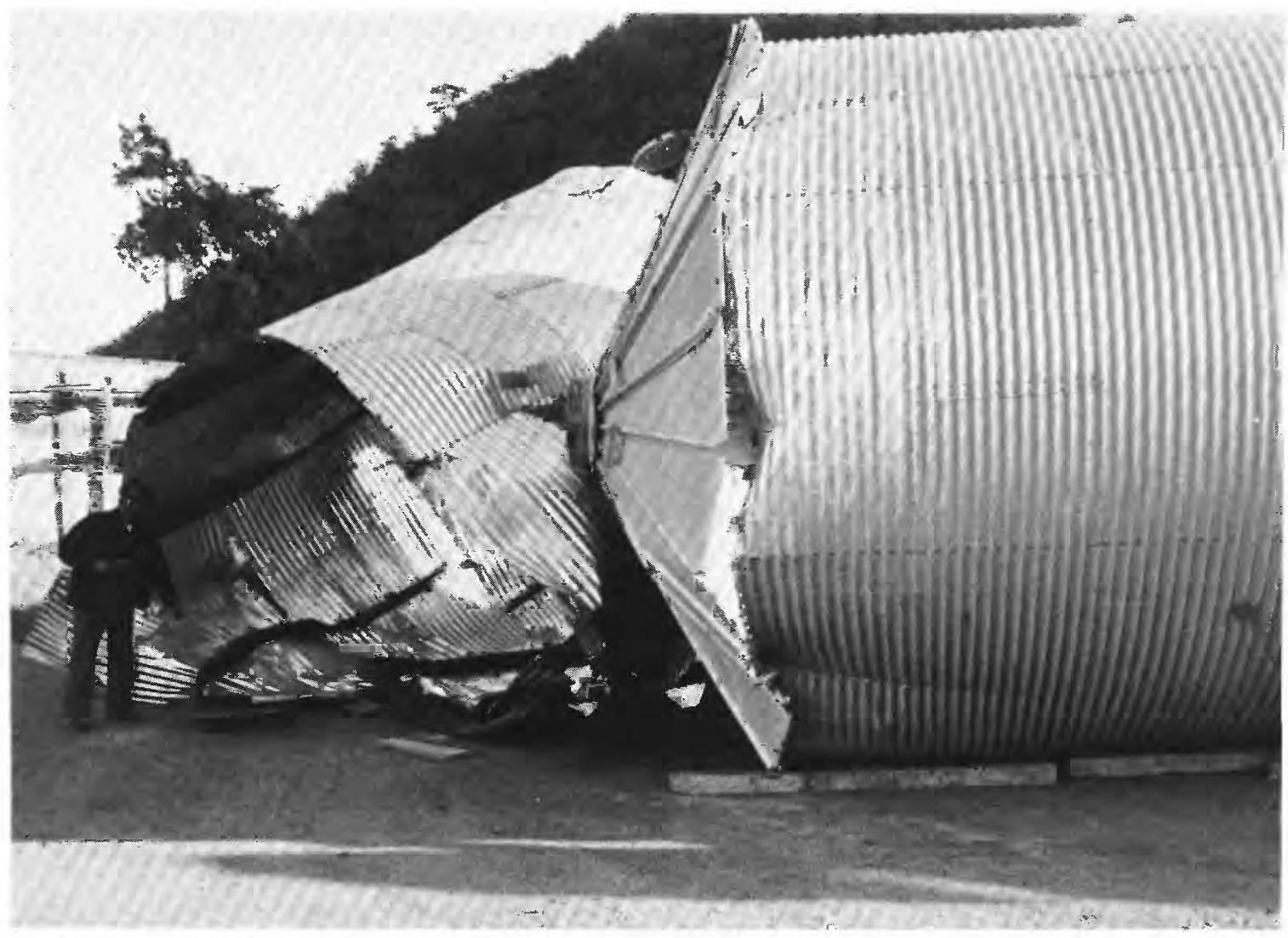

FIGURE 60.-Collapse of a corrugated-steel grain silo in Villalobos, $5 \mathrm{~km}$ southeast of Guatemala City. 

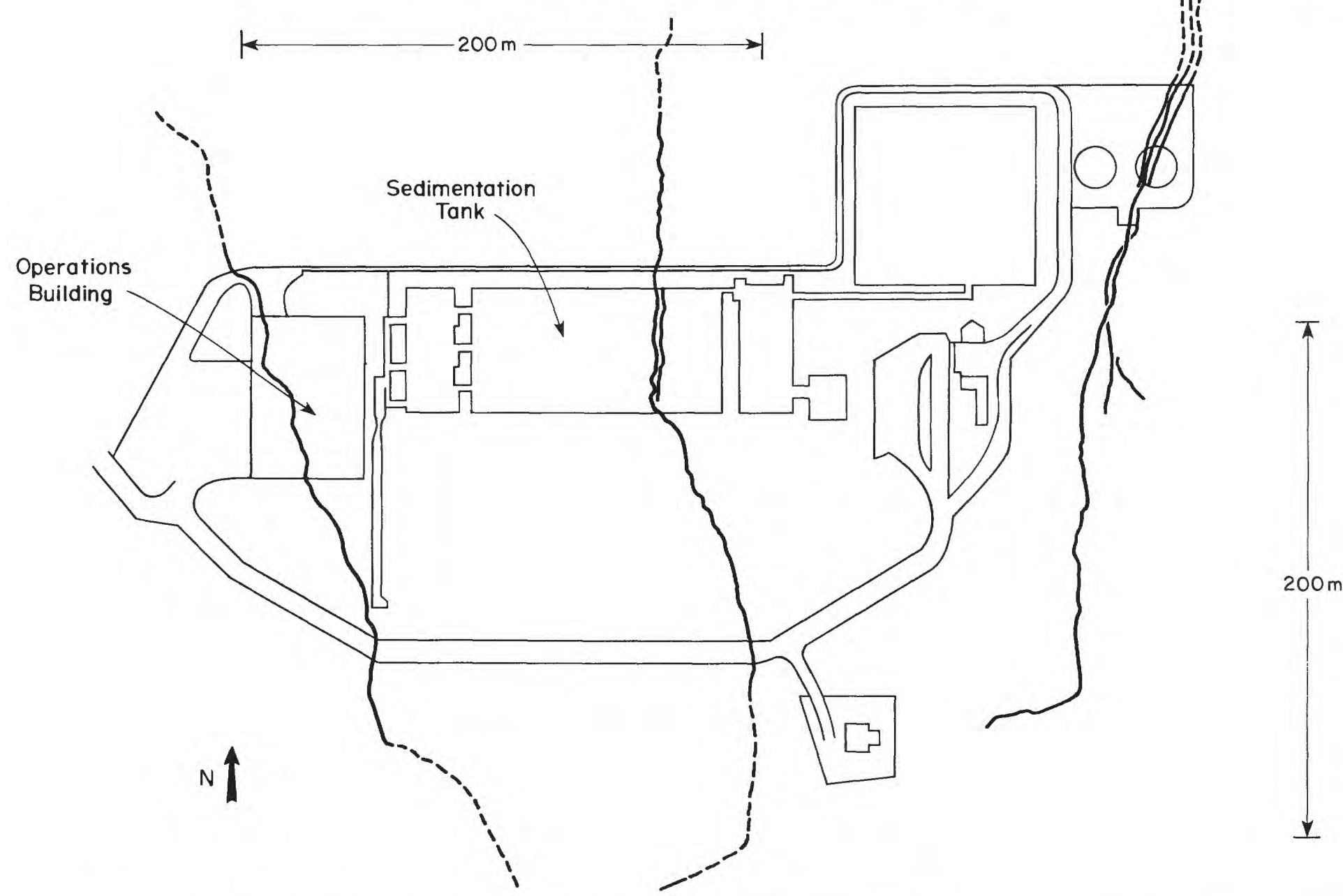

Figure 61.-Plan of sedimentation tank and Plant Lo de Coy of the XAYA-PIXCAYA project and cracks (heavy lines) running under and across the sedimentation tank.

FIGURE 62.-Severe damage to reinforced-masonry construction caused by secondary faulting in Colonia San Francisco (Zone 19). The fault strikes north to northeast.

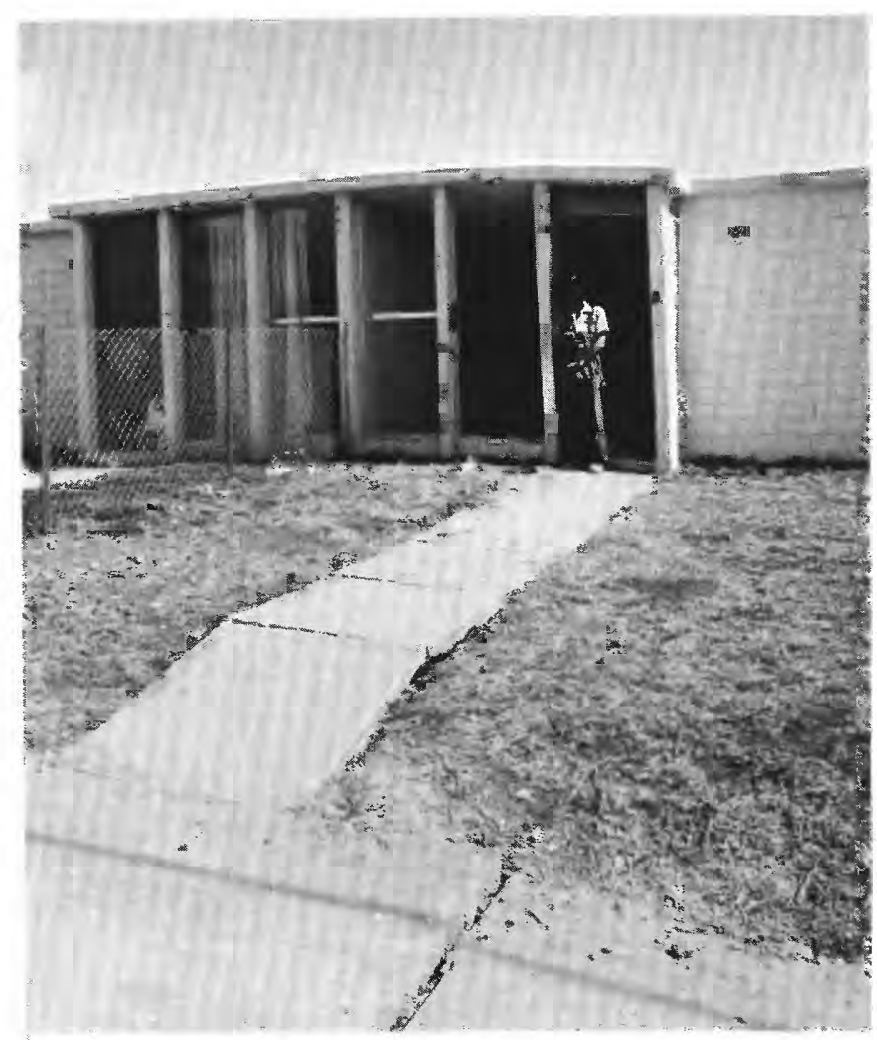




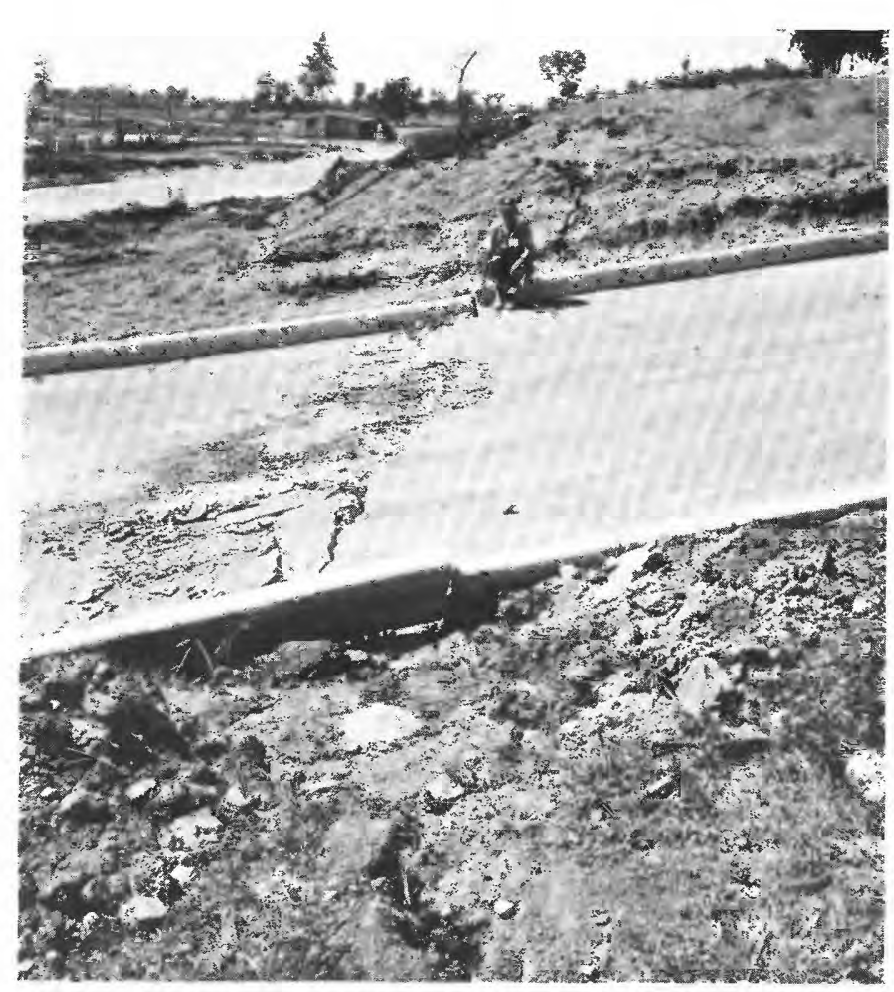

FIGURE 63.-Rupture across the San José Rosario subdivision. Fault with $13 \mathrm{~cm}$ vertical and $5 \mathrm{~cm}$ right-lateral displacements (Zone 19).

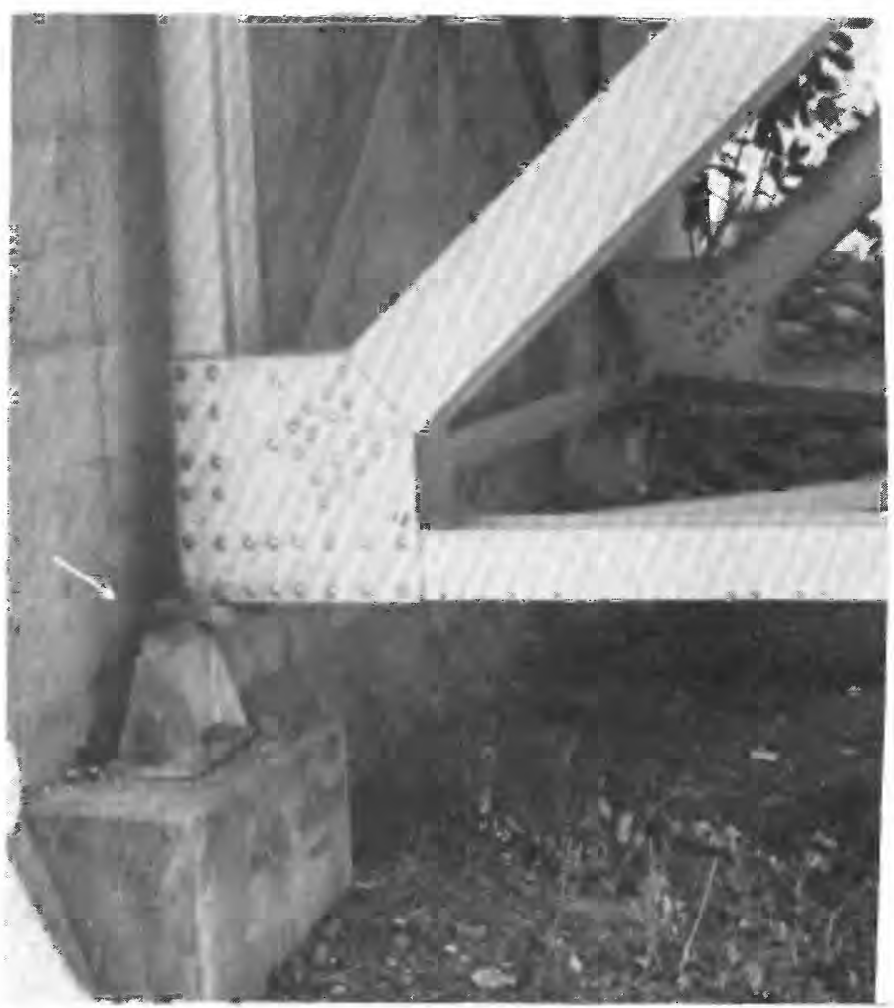

Figure 65.-Benque Viejo Bridge, on the verge of collapse after failure of supports, shown by arrow.

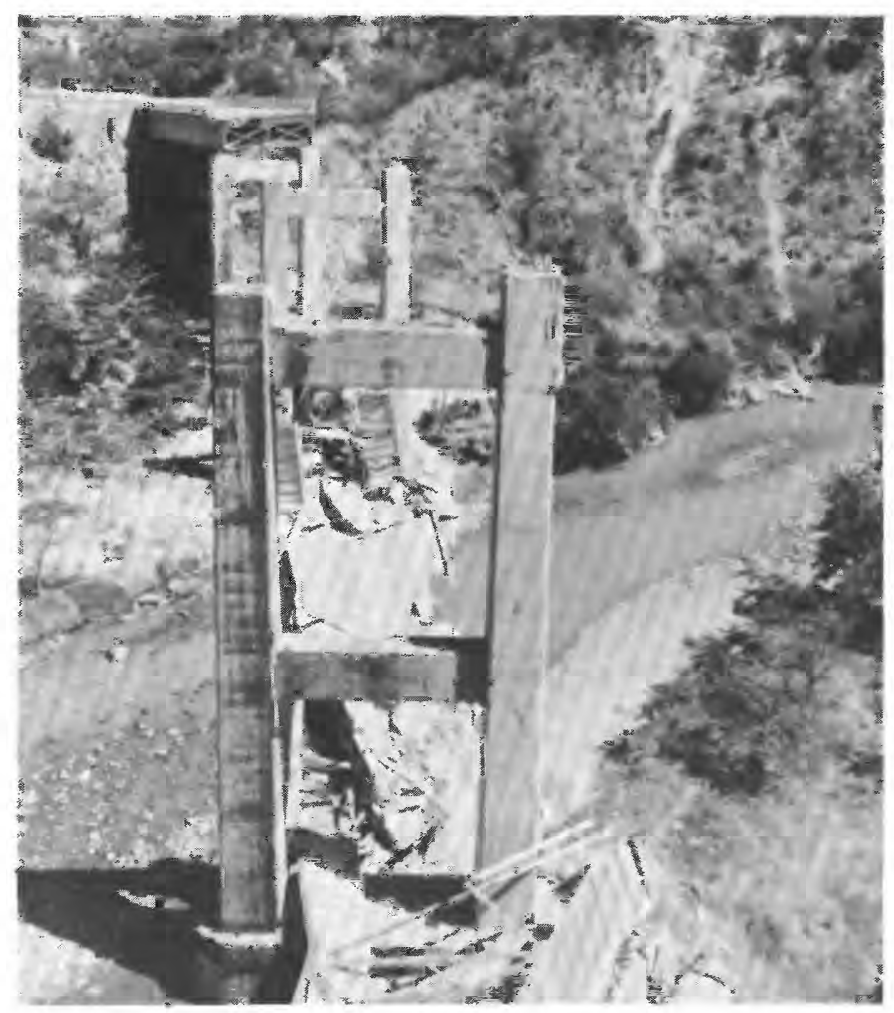

Figure 64.-Collapse of three central spans of the Agua Caliente Bridge, Kilometre 36 on the road to the Atlantic Ocean. This bridge was constructed in 1959.

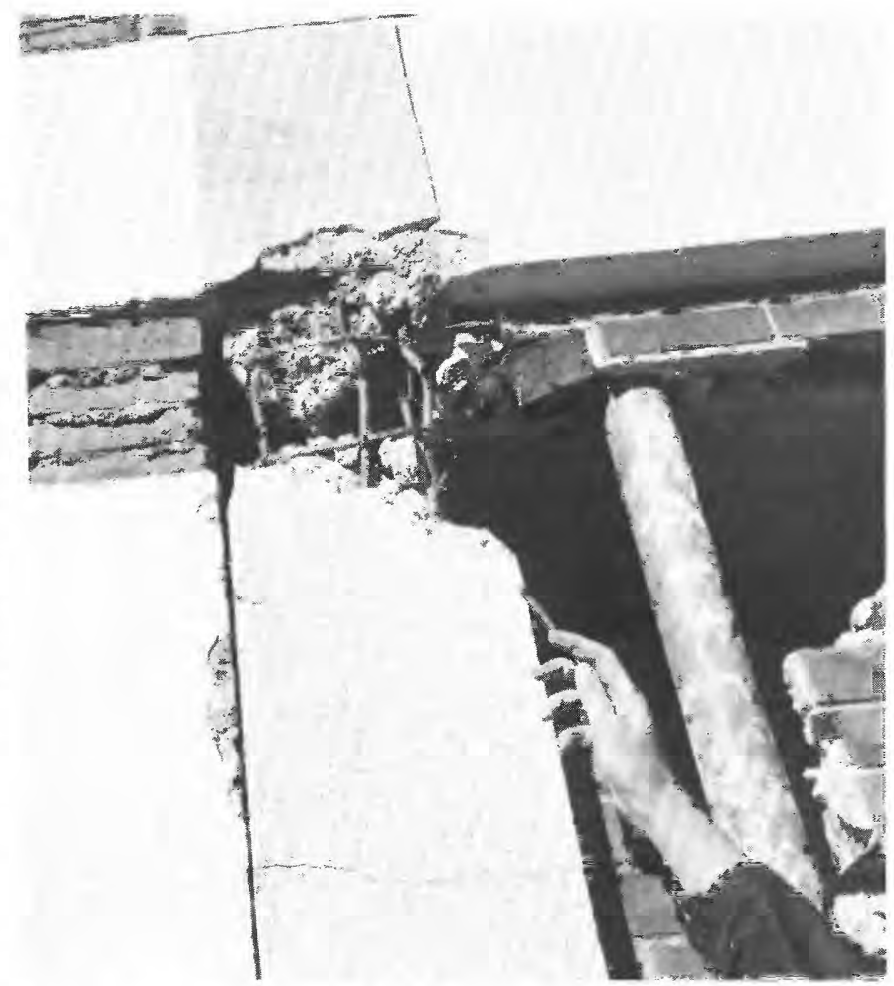

FIGURE 66.-Failure of short column in three-story framed reinforced-concrete structure in Guatemala City (Zone 7). 

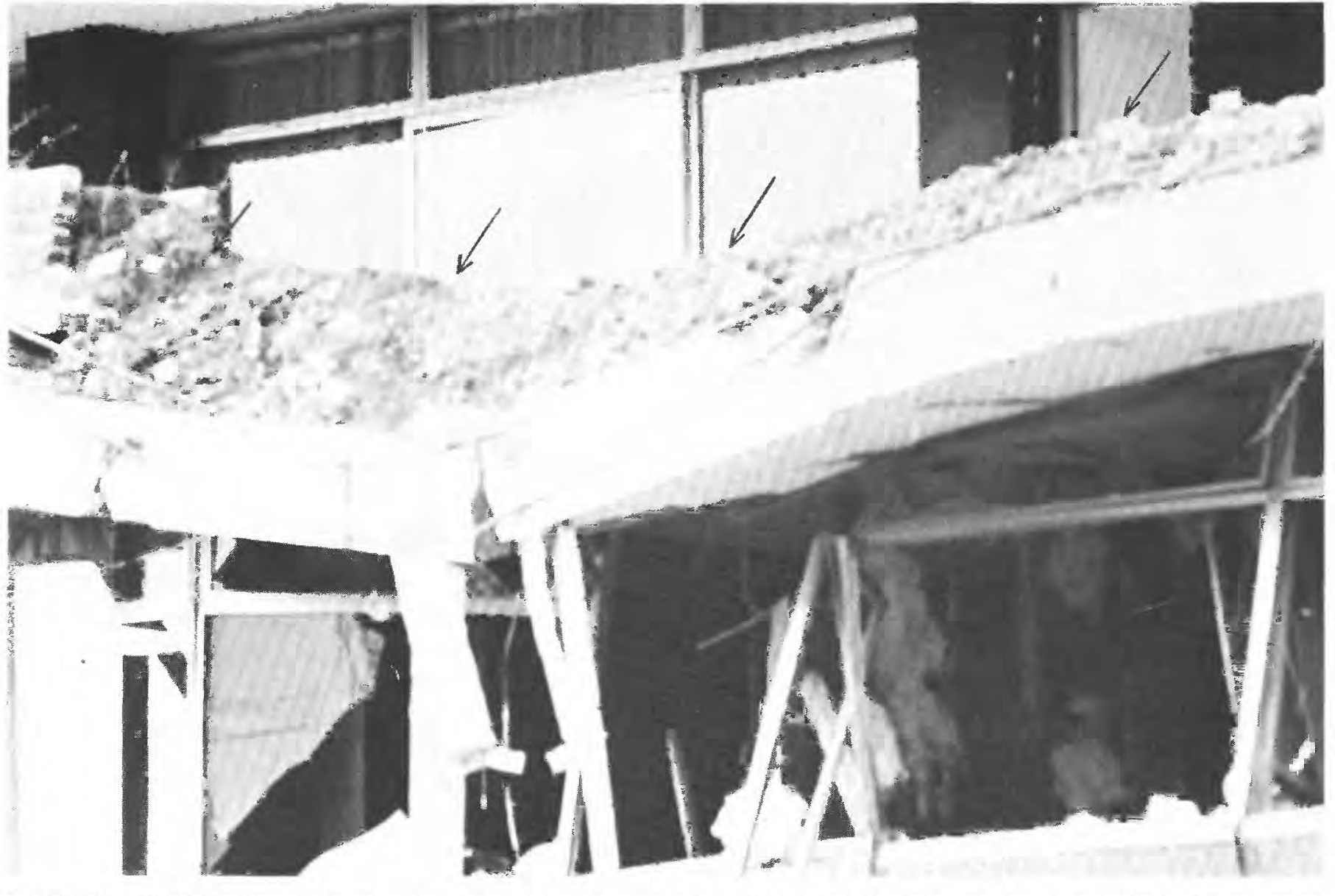

FIGURE 67.-Partial collapse of protruding first-story structure of the Cruz Azul 11-story reinforced-concrete building caused by falling (shown by arrows) of masonry walls from the two topmost stories, in Guatemala City (Zone 1).

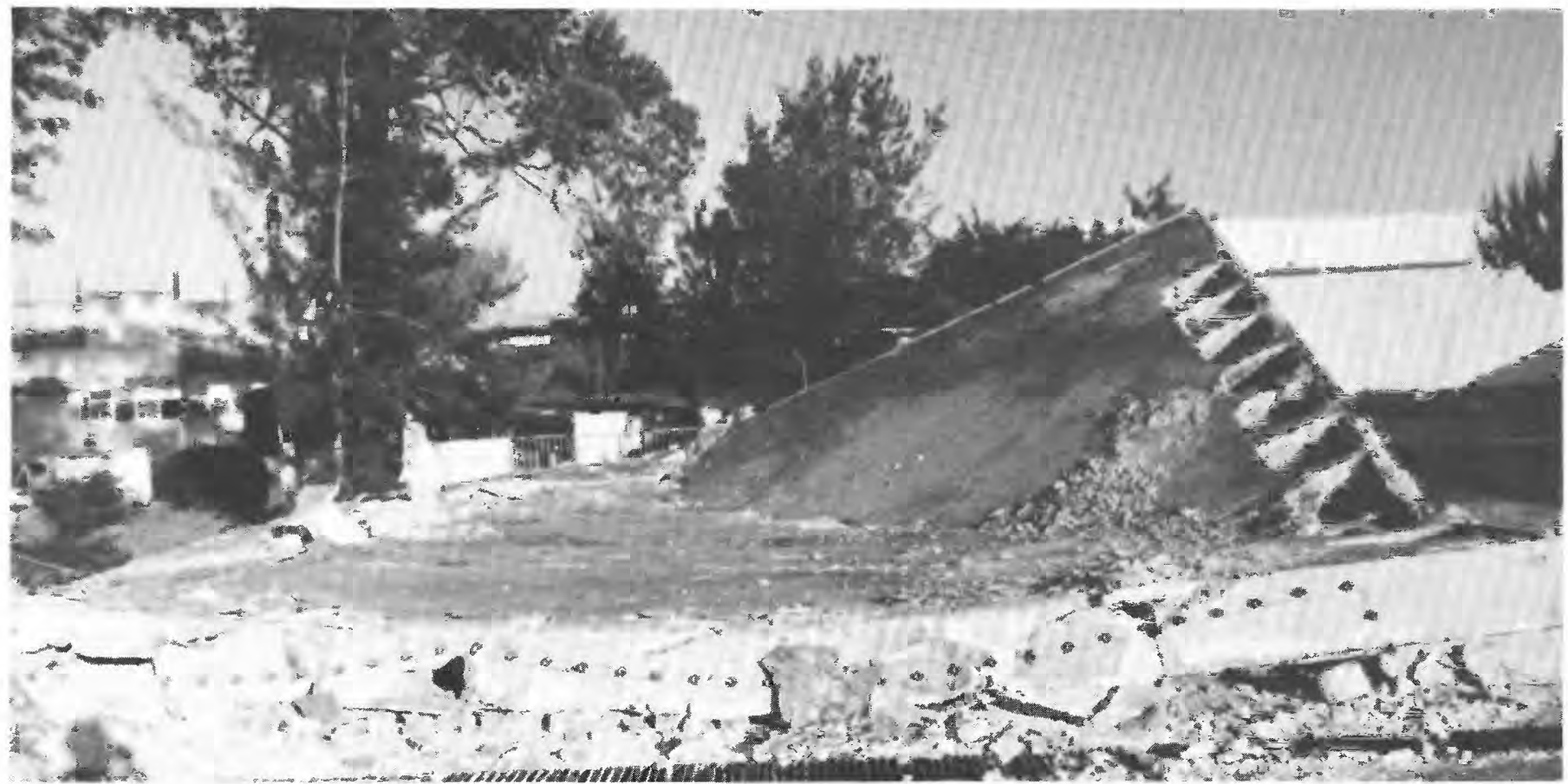

Figure 68.-Collapse of one-story reinforced-concrete framed structure in the Licorera Mixco, Mixco. 

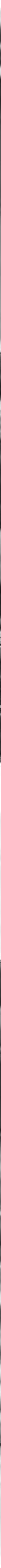

Figure 69.-A, Massive destruction of some adobe houses in Antigua, Guatemala, near the center of town. $B$, Large-scale destruction of adobe houses in Guatemala City, Calle 2 and Avenida 9A (Zone 2). C, Collapse of adobe houses in Guatemala City, Calle 22A and 34 Avenida (Zone 5). D, Collapse of adobe houses in Guatemala City, Calle 22 and Avenida 32 (Zone 5). 


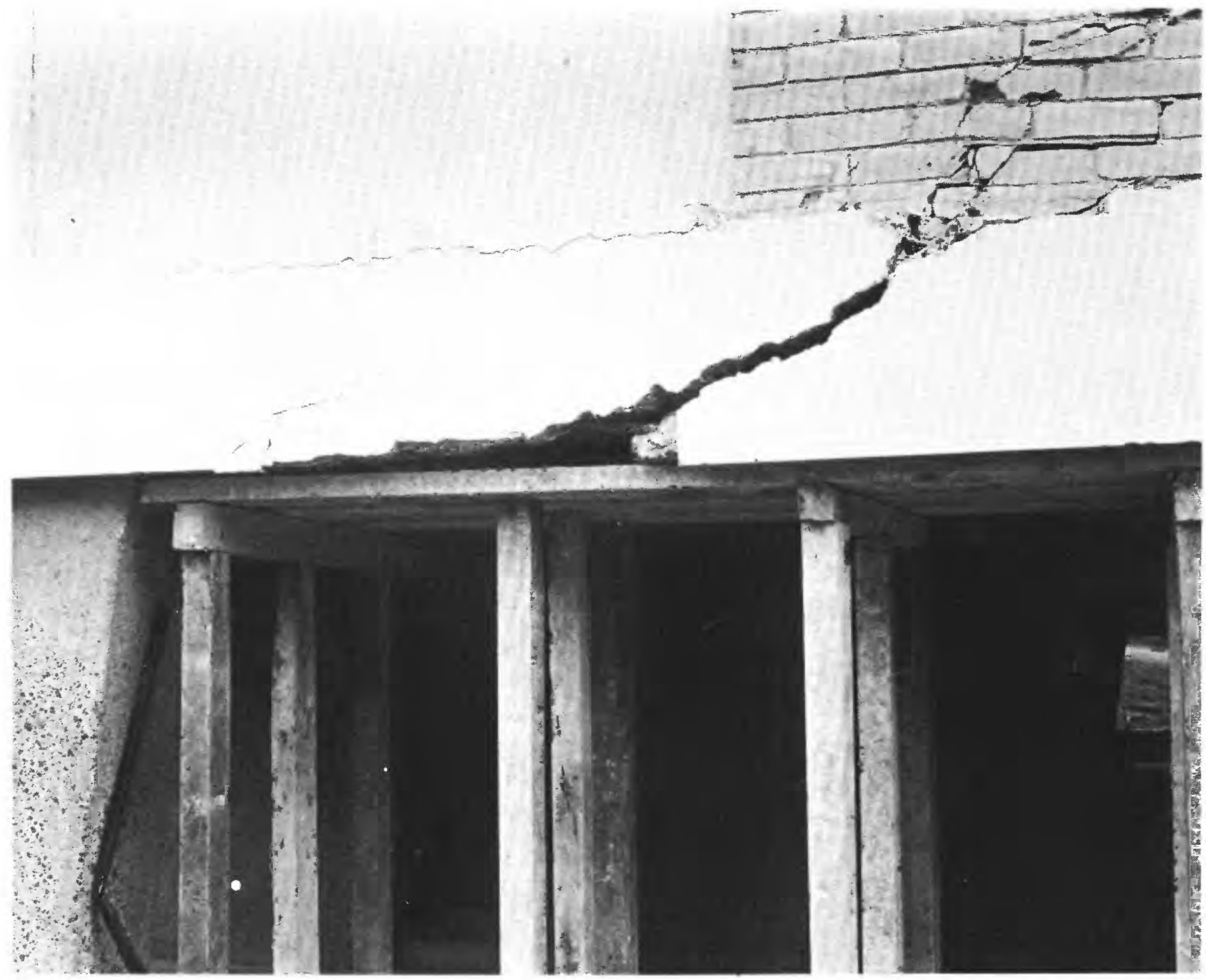

Figure 70.- Severe damage to flat beams and slab in the five-story reinforced-concrete Edificio ELGIN, in Guatemala City (Zone 14). 
THE GUATEMALAN EARTHQUAKE OF FEBRUARY 4, 1976, A PRELIMINARY REPORT

\title{
STRUCTURAL ENGINEERING OBSERVATIONS IN GUATEMALA CITY
}

\author{
By Karl V. STEINBRUgGe
}

\section{INTRODUCTION}

This paper reports on earthquake damage to buildings in Guatemala City and places special emphasis on earthquake-resistant structures and other building types having engineering relevance to construction in the United States.

The author inspected in detail the interiors and exteriors of about 25 major structures and, in a few instances, the construction drawings. His engineering colleagues, who formed a team under the auspices of the Earthquake Engineering Research Institute, collaborated on data collection, and they have had some input to this report. The views expressed in this report, however, are those of the author. This report is preliminary, and some details may change with further evaluation upon completion of the data collected.

\section{LIFE LOSS AND CONSTRUCTION}

The population of Guatemala City is about 700,000 , about 1,200 of whom may have died in the earthquake, according to one source (table 9). The fatality rate of 1 person in about 600 for Guatemala City contrasts sharply with the very high rates for some of the villages and small cities located much closer to the fault rupture. The deaths in Guatemala City resulted essentially from the collapse of adobe construction; this type of construction seems to be more prevalent in the northern and northwestern sections of the city. These zones were closer to the fault and to the source of seismic energy. In contrast to the damage patterns found in some locations near the fault (Espinosa and others, this report), widespread flattening of city blocks of adobe construction was not found in Guatemala City, which lies about $25 \mathrm{~km}$ from the fault break (Plafker and others, this report).

In contrast to the heavy mass construction such as adobe, light-mass all-metal structures, including one-story warehouses and aircraft hangars, performed excellently. Any comparative wind versus earthquake analysis would show that, if these lightmass structures can withstand a moderately strong windstorm, they can survive a major earthquake.

\section{DESIGN AND CONSTRUCTION PRACTICES}

As in many Latin American countries, Guatemala has no effective building code or enforcement procedures comparable to those found in the United States. Each design professional is allowed to establish his own design criteria and supervise his own construction without independent scrutiny, on the basis of his status as a registered professional. This practice does not preclude good construction, but, in effect, it places no limitations on the extent of poor construction. On the other hand, the local structural engineers and architects are, in general, excellent design professionals and comparable to their U.S. counterparts. Many Guatemalan professionals have been competently trained, as was seen from a brief review of several sets of construction drawings and from discussions with them. This is not to say, however, that poor design does not exist.

The quality of construction appears to be generally good for the newer buildings. High-strength concrete seems to be common. The quality of the reinforcing steel, however, may be open to question in some instance, since this steel does not appear to be locally tested and the strength characteristics (and other qualities) of imported steel often are not known.

There apparently are only two structural-steel multistory buildings in Guatemala City, the Finance Ministry Building (fig. 71) and the National Theater (which is only partially steel frame). In these two known instances, special quality-control efforts were made during fabrication and erection, and no significant damage occurred to them. 


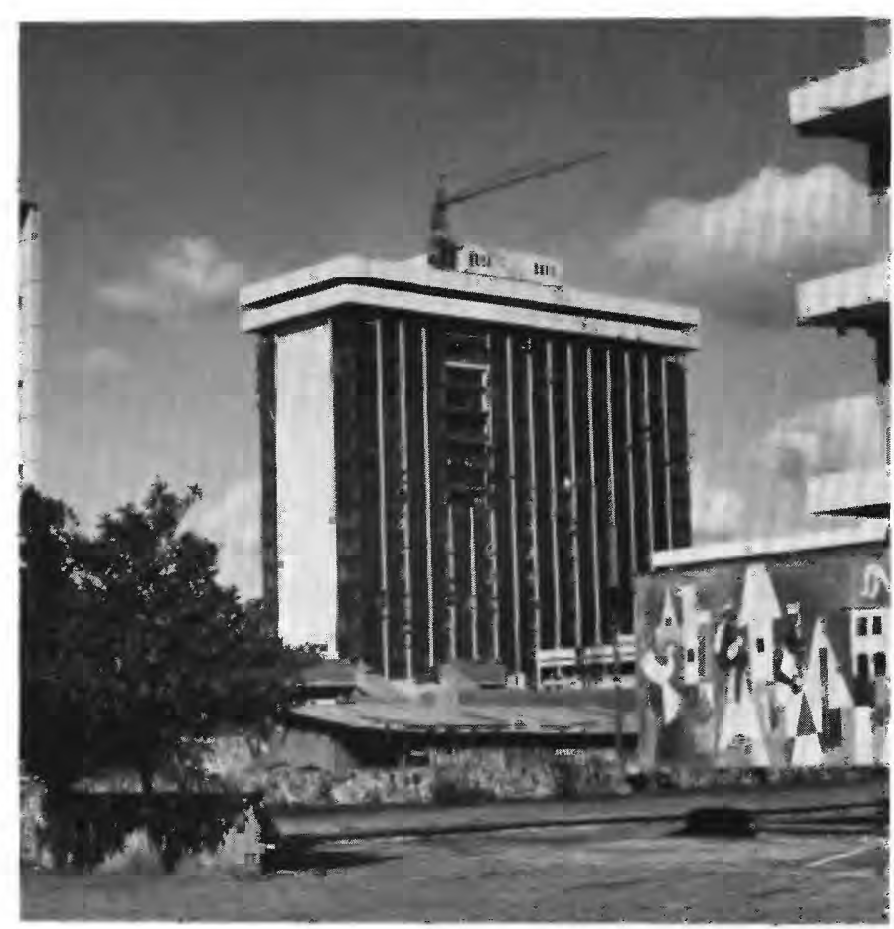

FIGURE 71.-The Finance Ministry Building (in Guatemala City) has 19 stories above ground plus 3 below. The undamaged steel-frame building is in the final stages of construction. (Photograph by W. H. Smith, American Iron and Steel Institute.)

Reinforced-concrete floors and roofs in major multistory buildings normally were of "waffle" construction. Forms for the waffles were customarily wooden rather than metal or plastic. Lateral-force resistance was commonly provided by frame action that utilized the waffle slabs and concrete columns, but some designs utilized reinforced-concrete shear walls.

Exterior walls were normally of reinforced-unitmasonry construction and were considered to be nonstructural for design purposes. These unitmasonry panel walls were strengthened by the inclusion of reinforced-concrete-bond beams and equivalent vertical members. This bracing system did what it was designed to do. There was no major fallout of these panels where the building remained intact. The exterior wall panels that fell from the Seguros Building were not reinforced.

Since the large majority of multistory buildings have been built in recent years, design and construction practices are modern. Guatemalan practices generally follow U.S. practices, and therefore many Guatemalan buildings will perform like those in the United States. For the usual building design, the Uniform Building Code appears to be the norm for seismic design.

\section{SPECIFIC DAMAGE OBSERVATIONS}

Tall buildings that were in close contact pounded together. Structural damage was minimal in most cases, and architectural damage was usually not excessive. However, whenever a building consisted of two independent structural units, such as a stair and/or elevator tower that was structurally independent from the rest of the building, then the electrical, plumbing, and mechanical equipment, and so on was broken at the floor lines, and the functional capacity of the building was reduced. One example of pounding damage was observed between the stair tower and the main structure of the 13-story Seguros Building where, at the roof, a $7-\mathrm{cm}$ separation was observed.

Folded plates and shells performed well, and no instances of significant internal damage are known. (The author, however, understands that there were one or more instances of such damage, but they remain unconfirmed.) The International Airport shown in figure 72 is one example of a folded-plate structure where minor spalling occurred at the tops and bases of columns, footing rocking was observed, some glass broke (see open windows in fig. 72), structural separations showed significant differential movements, and the stairs acting as diagonal braces were damaged, but the folded-plate roof sustained no damage.

A second example of folded plates and shells is the Universidad del Valle de Guatemala y Colegio Americano de Guatemala. The one-story hyperbolic paraboloid roofs performed well, but certain reinforced-concrete columns supporting these roofs were badly damaged. This damage can be attributed to the "structural performance of non-structural" brick panel walls that framed against these columns. These well-built brick walls did not fail, but they stiffened the columns to the point that they resisted a disproportionate share of the lateral forces.

Clearly, a better understanding of the importance of "non-structural" walls is vital to Guatemalan engineers as well as to many U.S. architects and engineers. Brick-infill walls between exterior columns as well as brick interior "partitions" used for tenants' improvements within a building were often well constructed and of rather substantial strength. Not only did these "non-structural" walls change the dynamic characteristics of the building, but often they also led to column failure or other significant damage. Another example of this kind of damage was observed at the two-story administration building adjacent to the airport control tower. 


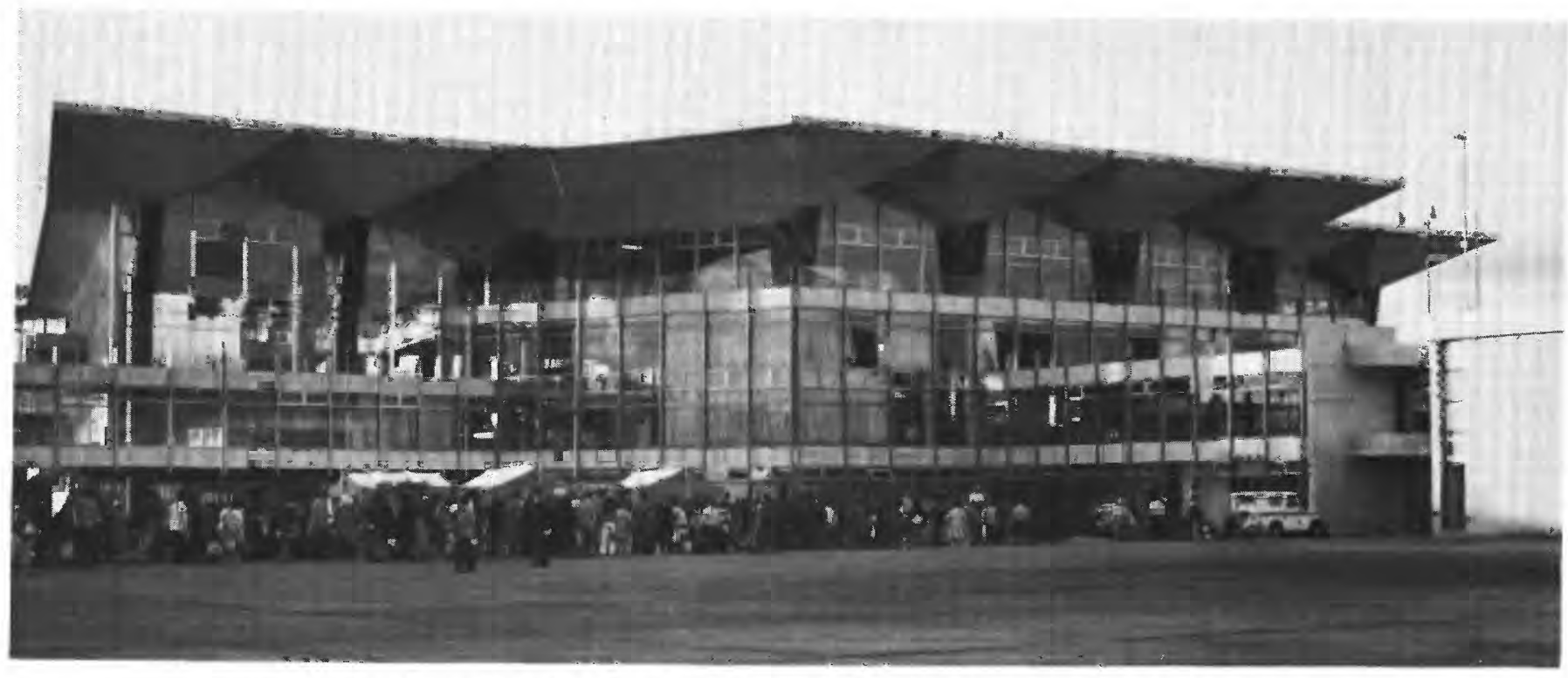

FIGURE 72.-International Airport at Guatemala City. Note that some windows are broken.

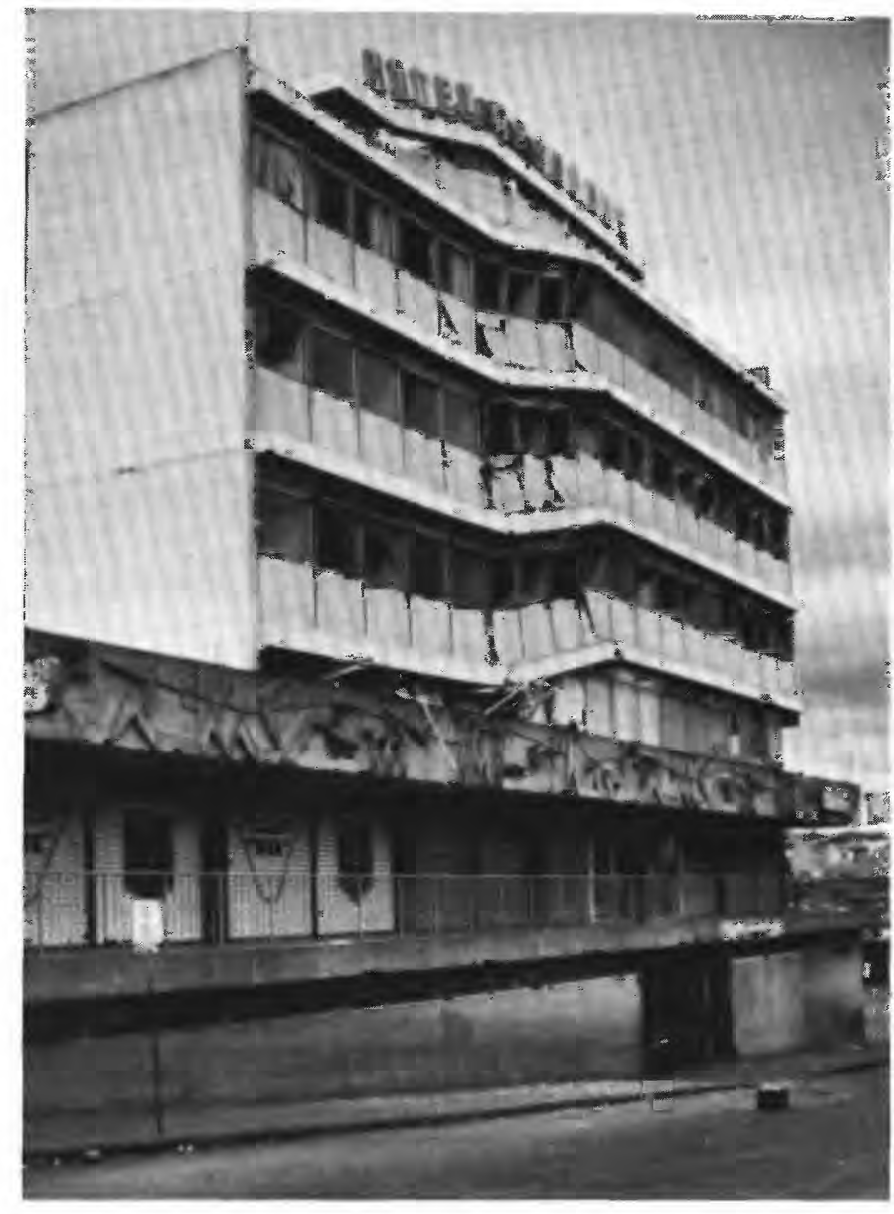

Figure 73.-Hotel Terminal in Guatemala City. Columns in third story collapsed.
Restated, a brick "non-structural" panel wall is an effective shear wall in a concrete frame as long as the "non-structural" wall remains intact.

Few instances of precast-concrete construction were inspected. One hospital structure, being a one-story "shear wall" building, had no damage to its roof, which consisted of a long span of precast concrete planks ("Spancrete"). There was no interconnection between the planks. A precast-concrete double-tee roof at the Universidad del Valle collapsed, but this building was in the course of construction, and its final bracing system was incomplete.

In general, building performance ranged from good to excellent, but several spectacular failures occurred. For example, in the Hotel Terminal (fig. 73), columns failed in the third story (fig. 74). Another example is the dormitory-classroom unit of the Catholic Boys School (Colegio San Javier), which collapsed owing to failure of its second-story columns (fig. 75). Figure 76 shows a collapsed column at the second floor of this unit. The time of night at which this earthquake occurred prevented major life loss in this building, since the first and second floors are used as classrooms.

A large number of hospitals were evacuated in Guatemala City owing to structural damage and to functional impairments.

Functional problems caused in multistory buildings were commonly in the form of elevator outages, and most elevators were still nonoperational 2 weeks after the event. Standby power remained in service 


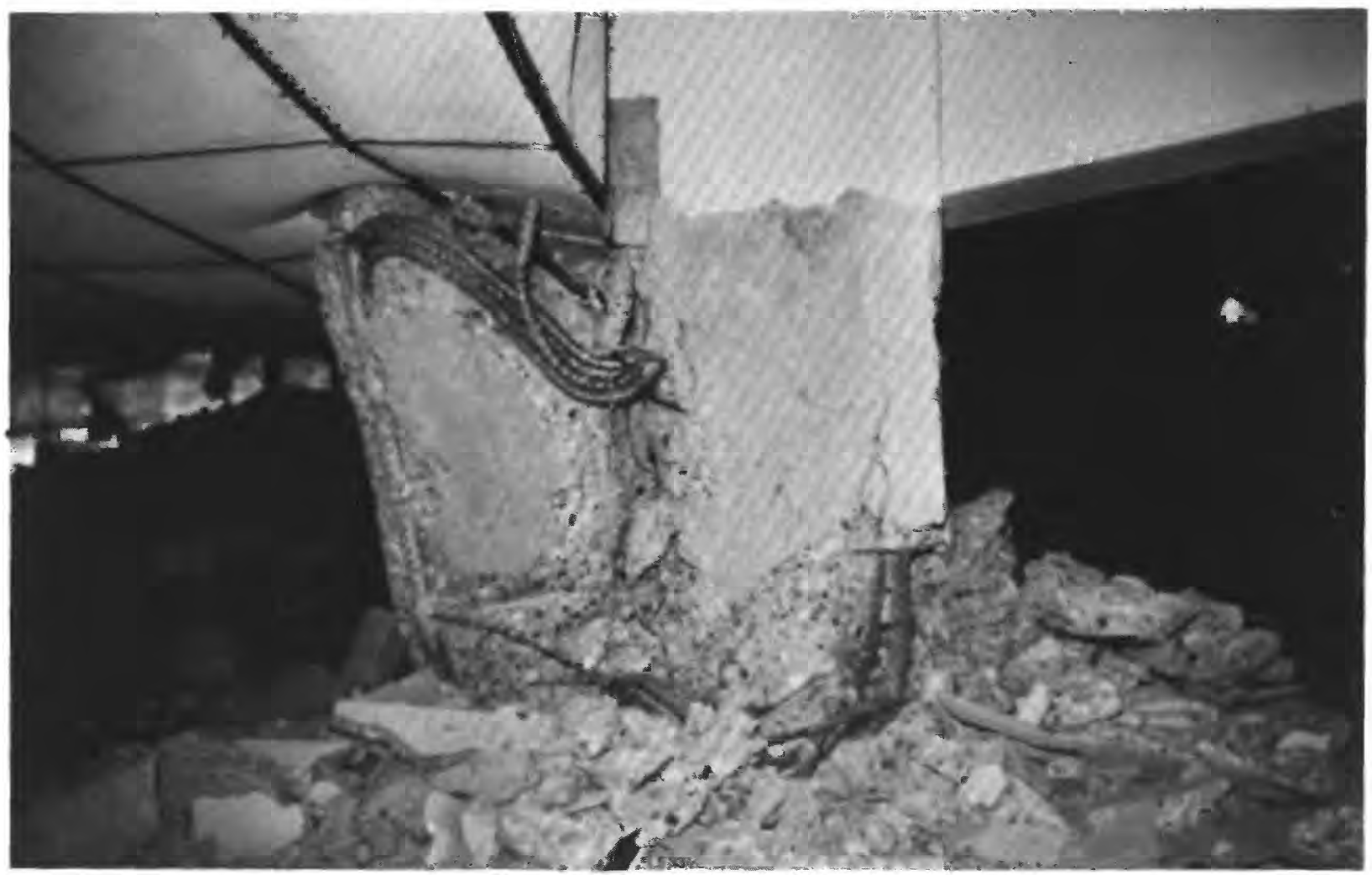

Figure 74.- Typical collapsed column in Hotel Terminal.

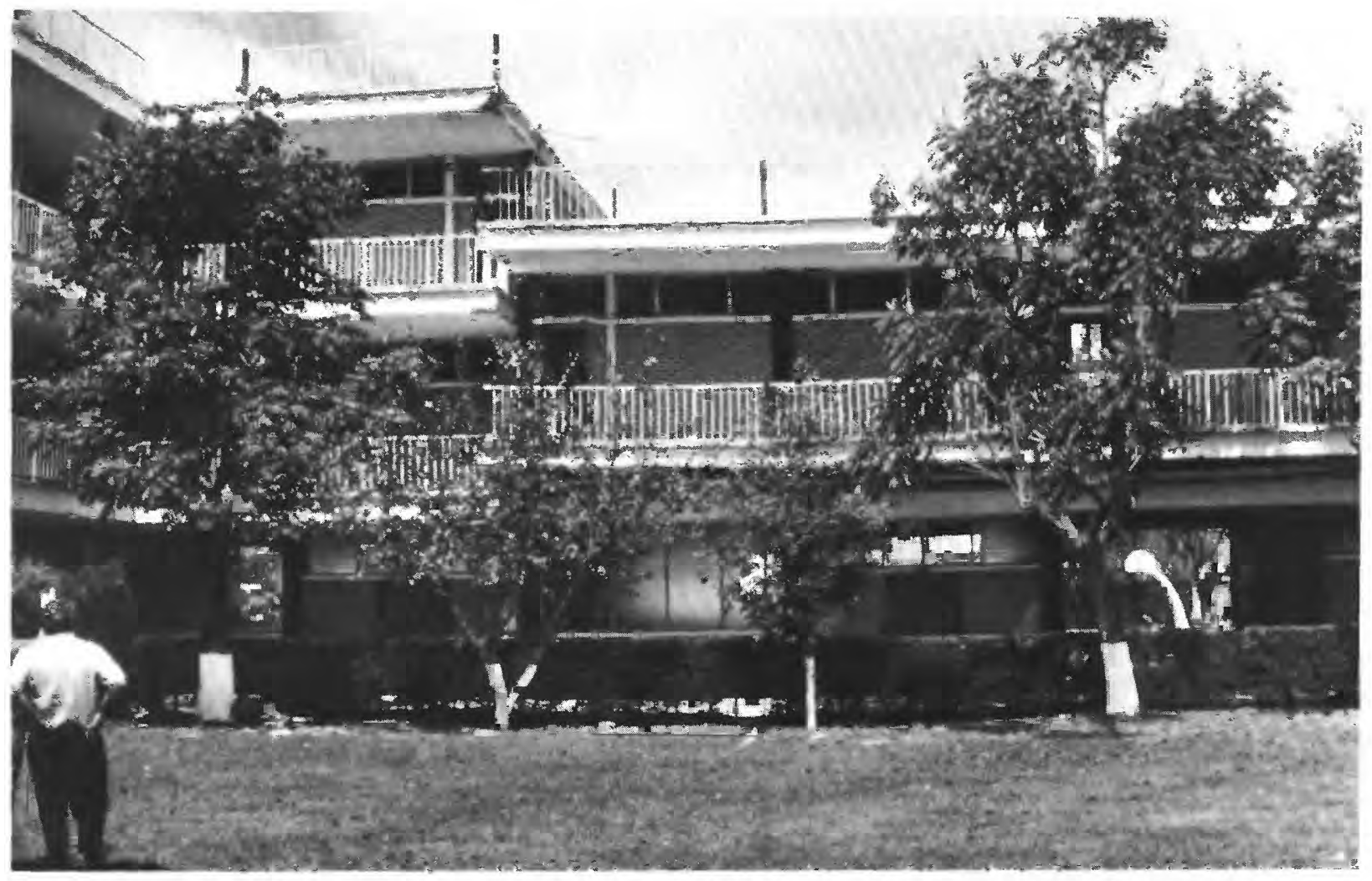

FIGURE 75.-Collapsed second story in one unit of the Catholic Boys School in Guatemala City. Roofs were originally at the same level. 


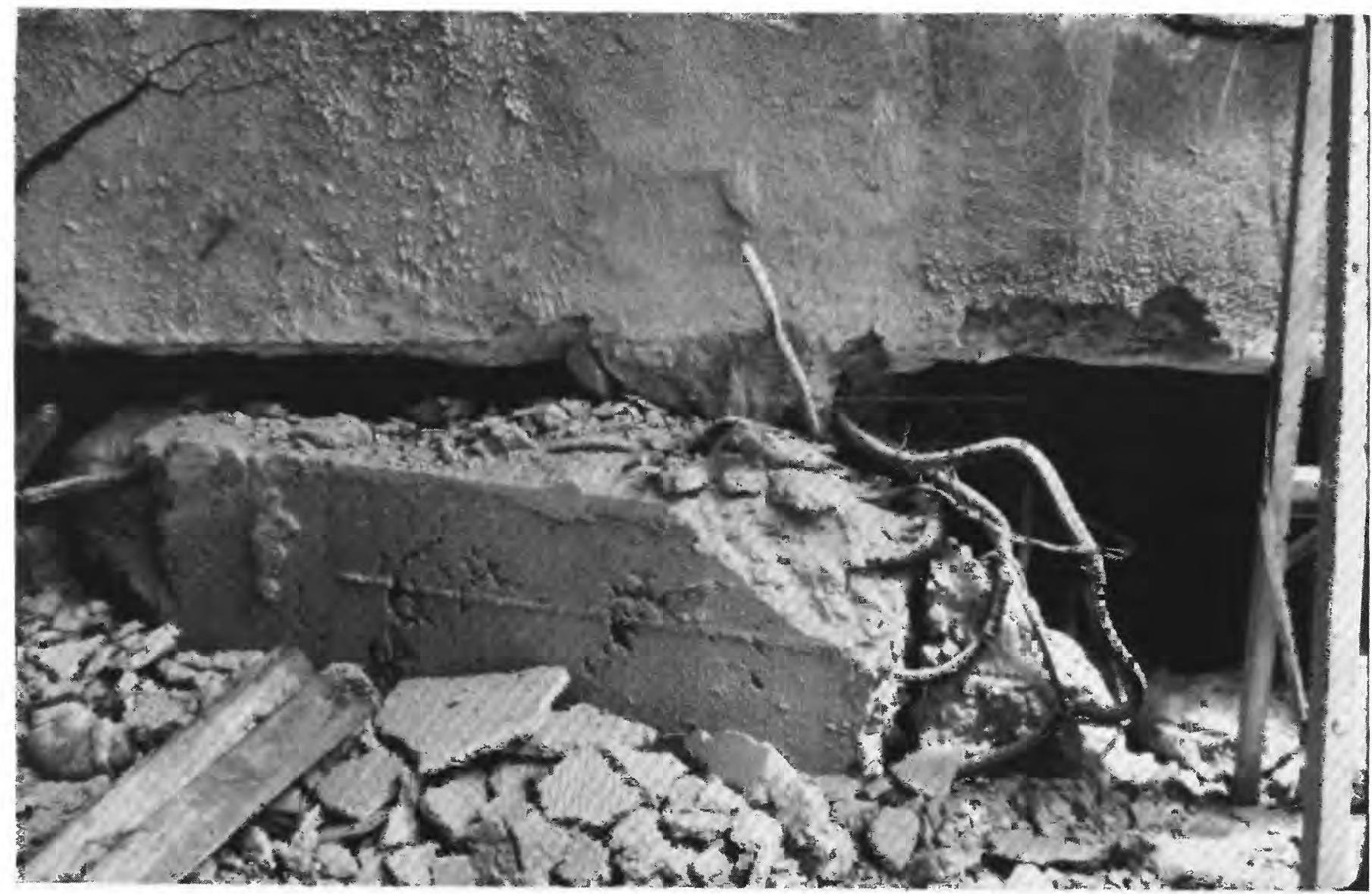

Figure 76.-Detail of column failure in second story at the Catholic Boys School. Story height now measured in inches.

at almost all the locations inspected by the author, but, undoubtedly, instances of failure did occur. Batteries required for standby power generally did not shift or, if they shifted, did not fall or break their connecting cables.

The nearest American counterparts to Guate- malan adobe buildings are the brick structures in the older sections of almost every U.S. city, including San Francisco and Los Angeles. These nonearthquake-resistant brick buildings, with their sandlime mortar that "holds brick apart," are a major potential source of loss of life. 
Aburto, Arturo, 1975, Reporte de los temblores ocurridos en Nicaragua los meses de Marzo a Junio de 1975: Buletin Instituto de Inv. Sismicas, v. 1, no. 1, 38 p.

Aki, Keiiti, 1966, Generation and propagation of $\mathrm{G}$ waves from the Niigata earthquake of June 16, 1964, part 2, estimation of earthquake moment, released energy, and stress-strain drop from $G$ wave spectrum: Tokyo Univ. Earthquake Research Inst. Bull., v. 44, p. 73-88.

Ambraseys, N. N., and Zátopek, A., 1968, The Varto-Ùstukran (Anatolia) earthquake of 19 August 1966; summary of field report: Seismol. Soc. America Bull., v. 58, no. 1, p. 47-102.

Benioff, Hugo, 1955, Mechanism and strain characteristics of the White Wolf fault as indicated by the aftershock sequence, in Oakeshott, G. B., ed., Earthquakes in Kern County, California, during 1952: California Div. Mines and Geology Bull. 171, p. 199-202.

Berg, G. V., and Husid, L. R., 1971, Structural effects of the Peru earthquake: Seismol. Soc. America Bull., v. 61, no. 3, p. 613-631.

- 1973, Structural behavior of the 1970 Peru earthquake, in World Conf. on Earthquake Eng., 5th, Proc., v. 1: Rome, Edigraf, p. 458-467.

Bonis, Samuel, 1976, The 1974 eruption of Volcan de Fuego, Guatemala [abs.]: EOS Am. Geophys. Union Trans., v. 57 , no. 4, p. 345 .

Bonis, Samuel, Bohnenberger, O. H., and Dengo, Gabriel, 1970, Mapa Geológico de la República de Guatemala [1st ed.]: Guatemala Instituto Geográfico Nacional.

Bowin, C. O., 1968, Geophysical study of the Cayman trough: Jour. Geophys. Research, v. 73, no. 16, p. 5159-5173.

Brigham, W. T., 1887, Guatemala, the land of the Quetzal: New York, Scribner, $453 \mathrm{p}$.

Brown, R. D., Ward, P. L., and Plafker, George, 1973, Geologic and seismologic aspects of the Managua, Nicaragua, earthquakes of December 23, 1972: U.S. Geol. Survey Prof. Paper 838, $34 \mathrm{p}$.

Brune, J. N., 1968, Seismic moment, seismicity, and rate of slip along major fault zones: Jour. Geophys. Research, v. 73 , no. 2 , p. $777-784$.

1970, Tectonic stress and the spectra of seismic shear waves from earthquakes: Jour. Geophys. Research, v. 75, no. 26 , p. 4997-5009.

Brune, J. N., and Allen, C. R., 1967, A microearthquake survey of the San Andreas fault system in southern California: Seismol. Soc. America Bull., v. 57, no. 2, p. 277-296.

Brune, J. N., and Engen, G. R., 1969, Excitation of mantle Love waves and definition of mantle wave magnitude: Seismol. Soc. America Bull., v. 59, no. 2, p. 923-933.

Burridge, R., and Knopoff, Leon, 1964, Body force equivalents for seismic dislocations: Seismol. Soc. America Bull., v. 54, no. 6, p. 1875-1888.

Carey, S. W., 1958, The tectonic approach to continental drift, in Continental drift, a symposium: Hobart, Univ. of Tasmania, p. 177-355.

Carr, M. J., 1974, Tectonics of the Pacific margin of northern Central America: New Hampshire, Dartmouth Coll., Ph.D. dissert., $181 \mathrm{p}$.

Chinnery, M. A., 1963, The stress changes that accompany strike-slip faulting: Seismol. Soc. America Bull., v. 53, no. 5, p. 921-932.
Dengo, Gabriel, 1968, Estructura geologica, historia tectonica, y morfologia de America Central: Mexico, Centro Regional de Ayuda Técnica, Agencia para el Desarrollo Internacional, $50 \mathrm{p}$.

1969, Problems of tectonic relations between Central America and the Caribbean: Gulf Coast Assoc. Geol. Socs., 19th Ann. Mtg., Trans., p. 311-320.

Dengo, Gabriel, and Bohnenberger, Otto, 1969, Structural development of northern Central America, in McBirney, A. R., ed., Tectonic relations of northern Central America and the western Caribbean: Am. Assoc. Petroleum Geologists Mem. 11, p. 203-220.

Dewey, J. W., 1976, Seismicity of northern Anatolia: Seismol. Soc. America Bull. [In press.]

Dewey, J. W., and Algermissen, S. T., 1974, Seismicity of the Middle America arc-trench system near Managua, Nicaragua, in Special Papers on the Managua, Nicaragua, earthquakes of December 23, 1972: Seismol. Soc. America Bull., v. 64 , no. 4, p. 1033-1048.

Eaton, J. P., O'Neill, M. E., and Murdock, J. N., 1970, Aftershocks of the 1966 Parkfield-Cholame, California, earthquake-a detailed study: Seismol. Soc. America Bull., v. 60 , no. 4 , p. 1151-1197.

Eisenberg, A., Husid, Raul, and Luco, J. E., 1972, A preliminary report-the July 8, 1971, Chilean earthquake: Seismol. Soc. America Bull., v. 62, no. 1, p. 423-430.

Engdahl, E. R., 1971, Explosion effects and earthquakes in the Amchitka Island region: Science, v. 173, no. 4003, p. 1232-1235.

- 1973, Relocation of intermediate depth earthquakes in the central Aleutians by seismic ray tracing: Nature Phys. Sci., v. 245, no. 141, p. 23-25.

Espinosa, A. F., Husid, R., and Algermissen, S. T., 1975, Seismological and engineering features of the October 3, 1974, Lima earthquake [paper 141]: European Conf. on Earthquake Eng., 5th, Istanbul 1975, Proc., v. 2.

Espinosa, A. F., Husid, R., Algermissen, S. T., and de las Casas, J., 1976, The Lima earthquake of October 3, 1974, intensity distribution: Seismol. Soc. America Bull. [In press.]

Fahquist, D. A., and Davies, D. K., 1971, Fault-block origin of the western Cayman Ridge, Caribbean Sea: Deep-Sea Research, v. 18, no. 2, p. 243-253.

Freeland, G. L., and Dietz, R. S., 1971, Plate tectonic evolution of Caribbean-Gulf of Mexico region: Nature, v. 232, no. 5305, p. 20-23.

Gill, J. E., 1972, Continued confusion in the classification of faults; Reply: Geol. Soc. America Bull., v. 83, no. 3, p. $925-926$.

Gutenberg, Beno, and Richter, C. F., 1954, Seismicity of the Earth [2d ed.]: New York, Hafner, 310 p.

Hanks, T. C., 1975, Strong ground motion of the San Fernando, California, earthquake-ground displacements: Seismol. Soc. America Bull., v. 65, no. 1, p. 193-225.

Hess, H. H., and Maxwell, J. C., 1953, Caribbean research project: Geol Soc. America Bull., v. 64, no. 1, p. 1-6.

Holcombe, T. L., Vogt, P. R., Matthews, J. E., and Murchison, R. R., 1973, Evidence for sea-floor spreading in the Cayman Trough: Earth and Planetary Sci. Letters, v. 20, no. 3 , p. 357-371.

Husid, R., and Espinosa, A. F., 1975, Seismological and engineering aspects of the March 6, 1974, Carazo earthquake (Nicaragua) [paper 137]: European Conf. on Earthquake Eng., 5th, Istanbul 1975, Proc., v. 2. 
Husid, R., and Gajardo, E., 1970, Aspectos sismologicos y estructurales en el terremoto del Peru del 31 de Mayo de 1970: Simposio Panamericano de Estructuras, Buenos Aires, Argentina.

Husid, R., Espinosa, A. F., and de las Casas, J., 1976, The Lima earthquake of October 3, 1974, damage distribution: Seismol. Soc. America Bull. [In press.]

Jordan, T. H., 1975, The present-day motions of the Caribbean plate: Jour. Geophys. Research, v. 80 , no. 32, p. 4433-4439.

Jorquera, L., 1964, Estudio experimental sobre la resistencia de muros de Albañileria sometidos a cargas horizontales: Rev. Idiem, v. 3, no. 3., p. 193-222.

Kanamori, Hiroo, and Anderson, D. L., 1975, Theoretical basis of some empirical relations in seismology: Seismol. Soc. America Bull., v. 65, no. 5, p. 1073-1095.

Keilis-Borok, V. I., 1959, On estimation of the displacement in an earthquake source and of source dimensions: Annali Geofisica, v. 12, p. 205-214.

Kelleher, John, Sykes, Lynn, and Oliver, Jack, 1973, Possible criteria for predicting earthquake locations and their application to major plate boundaries of the Pacific and the Caribbean: Jour. Geophys. Research, v. 78, no. 14, p. 2547-2585.

Kesler, S. E., 1971, Nature of ancestral orogenic zone in nuclear Central America: Am. Assoc. Petroleum Geologists Bull., v. 55, no. 12 , p. 2116-2129.

King, Cyi-yu, and Knopoff, Leon, 1968, Stress drop in earthquakes: Seismol. Soc. America Bull., v. 58, no. 1, p. 249257.

King, P. B., compiler, 1969, Tectonic map of North America: Reston, Va., U.S. Geol. Survey, 2 sheets.

Knopoff, Leon, 1958, Energy release in earthquakes: Geophys. Jour., v. 1 , no. 1 , p. 44-52.

Koch, A. J., and McLean, Hugh, 1975, Pleistocene tephra and ash-flow deposits in the volcanic highlands of Guatemala: Geol. Soc. America Bull., v. 86, no. 4, p. 529-541.

Lee, W. H. K., and Lahr, J. C., 1975, HYPO71 (revised)-a computer program for determining hypocenter, magnitude, and first motion pattern of local earthquakes: U.S. Geol. Survey open-file rept., $113 \mathrm{p}$.

Lee, W. H. K., Bennett, R. E., and Meagher, K. L., 1972, A method of estimating magnitude of local earthquakes from signal duration: U.S. Geol. Survey open-file rept., $28 \mathrm{p}$.

Malfait, B. T., and Dinkelman, M. G., 1972, Circum-Caribbean tectonic and igneous activity and the evolution of the Caribbean plate: Geol. Soc. America Bull., v. 83, no. 2, p. 251-271.

McBirney, A. R., 1963, Geology of a part of the Central Guatemalan Cordillera: Calif. Univ. Pubs. Geol. Sci., v. 38 , no. 4 , p. $177-242$.

McBirney, A. R., and Bass, M. N., 1969, Structural relations of pre-Mesozoic rocks of northern Central America, in Tectonic relations of northern Central America and the western Caribbean: Am. Assoc. Petroleum Geologists Mem. 11, p. 269-280.

Minster, J. B., Jordan, T. H., Molnar, Peter, and Haines, E., 1974, Numerical modelling of instantaneous plate tectonics: Roy. Astron. Soc. Geophys. Jour., v. 36, no. 3, p. 541-576.

Mitronovas, Walter, Isacks, Bryan, and Seeber, Leonardo, 1969, Earthquake locations and seismic wave propagation in the upper $250 \mathrm{~km}$ of the Tonga Island arc: Seismol. Soc. America Bull., v. 59, no. 3, p. 1115-1135.

Molnar, Peter, and Sykes, L. R., 1969, Tectonics of the Caribbean and Middle America regions from focal mechanisms and seismicity: Geol. Soc. America Bull., v. 80, no. 9, p. 1639-1684.

Montessus de Ballore, Fernard de, 1888, Tremblements de terre et éruptions volcaniques au Centre-Amérique: Dijon, Societé de sciences naturelles de Saône-et-Loire, 293 p.

Morgan, W. J., 1971, Convection plumes in the lower mantle: Nature, v. 230, no. 5288, p. 42-43.

Page, R. A., ed., Interim report on the Guatemalan earthquake of 4 February 1976 and the activities of the U.S. Geological Survey earthquake investigation team: U.S. Geol. Survey open-file rept., $31 \mathrm{p}$.

Penney, W. T., 1918, Guatemala earthquake shifts steel viaduct on its piers: Eng. News-Record, v. 80, no. 21, p. 999.

Pinet, P. R., 1972, Diapirlike features offshore Honduras; implications regarding tectonic evolution of Cayman Trough and Central America: Geol. Soc. America Bull., v. 83 , no. 7 , p. 1911-1921.

Richter, C. F., 1958, Elementary seismology: San Francisco, W. H. Freeman and Co., 768 p.

Savage, J. C., 1971, A theory of creep waves propagating along a transform fault: Jour. Geophys. Research, v. 76, no. 8, p. 1954-1966.

Seismological Society of America, 1911-1975, Seismological notes: Seismol. Soc. America Bull., v. 1-65, pagination varies.

Stoiber, R. E., and Carr, M. J., 1973, Quaternary volcanic and tectonic segmentation of Central America: Bull. Volcanol., v. 37 , no. 3 , p. $304-325$.

Tarr, A. C., and King, K. L., 1976, Puerto Rico seismic program: U.S. Geol. Survey open-file rept., 23 p.

Thatcher, Wayne, 1975, Strain accumulation and release mechanism of the 1906 San Francisco earthquake: Jour. Geophys. Research, v. 80 , no. 35, p. $4862-4872$.

Uchupi, Elazar, 1973, Eastern Yucatan continental margin and western Caribbean tectonics: Am. Assoc. Petroleum Geologists Bull., v. 57, no. 7, p. 1075-1085.

U.S. Coast and Geodetic Survey, 1960, United States earthquakes: Washington, D.C., Govt. Printing Office, 90 p.

1965, United States earthquakes: Washington, D.C., Govt. Printing Office, $91 \mathrm{p}$.

Vassaux, P. J., 1969, Cincuenta años de sismologia en Guatemala: Guatemala City, Observatorio Nacional, p. 85-98.

Wallace, R. E., 1968, Earthquake of August 19, 1966, Varto area, eastern Turkey: Seismol. Soc. America Bull., v. 58 , no. 1 , p. 11-45.

Ward, P. L., Endo, E. T., Harlow, D. H., Allen, Tex, Marquez, Dan, and Eaton, J. P., 1974, Development and evaluation of a prototype global volcano surveillance system utilizing the ERTS-1 satellite data collection system: U.S. Geol. Survey open-file rep., $154 \mathrm{p}$.

Williams, Howel, and McBirney, A. R., 1969, Volcanic history of Honduras: Calif. Univ. Pubs. Geol. Sci., v. 85, 101 p.

Williams, Howel, McBirney, A. R., and Dengo, Gabriel, 1964, Geologic reconnaissance of southeastern Guatemala: Calif. Univ. Pubs. Geol. Sci., v. 50, 62 p.

Wilson, J. T., 1963, A possible origin of the Hawaiian Islands: Canadian Jour. Physics, v. 41, no. 6, p. 863-870. 
CHRONOLOGICAL HISTORICAL REGORD OF

DAMAGING EARTHQUAKES IN GUATEMALA, 1526-1976

[Reference sources listed at end of table. Dashes mean no data. $h$ is the depth of focus for the earthquake. Asterisks mark earthquakes plotted in fig. 3. Station codes are given in the Glossary]

NONINSTRUMENTAL DATA

\begin{tabular}{llcc}
\hline Date & Time (local time) & Place & Reference \\
\hline 1526 & $\begin{array}{l}\text { July } 19 \text { or } 20 \\
\text { Damaging earthquake } \\
\text { Ciudad Vieja. }\end{array}$ & $\begin{array}{c}\text { Shat caused removal of } \\
\text { Spanish settlement to }\end{array}$ & \\
1541 September $10 *$ & Ciudad Vieja & 1,3
\end{tabular}

1541 September $10 \%$

Two destructive earthquakes killed approximately 150 Spaniards and at least 600 Indians and Negroes. Two days of rain prior to the earthquakes added damage from avalanches and landslides. The primary Spanish settlement then moved to Antigua.

1565 February

$----$

3

Series of violent earthquakes caused extensive damage in and near Antigua.

1575

Several large shocks caused damage in San Salvador and also in Antigua, Guatemala.

1577 November 30

-.-.-..-

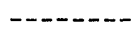

Earthquake swarm. Largest shock caused much damage in Antigua.

1586 December 23*

- - - - - -

$-\cdots---$

$1,3,6$

Long earthquake sequence beginning January 16,1585 , and ending with largest shock on above date. Accompanied by eruption of Fuego Volcano. Antigua was destroyed, causing many deaths.

1607 April*

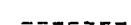

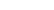

Many buildings collapsed, killing a number of people in Antigua.

1651 February 18

1,3

Extensive damage in Antigua.

1681 July 22

-.-.-.--

-------

3

A swarm of earthquakes caused extensive damage in Antigua.

1684 August

- - - - - -

$------$

Earthquake swarm caused notable damage in Antigua area.

1689 February 12

- - - - - -

Earthquake swarm caused extensive damage and loss of life in Antigua area. Stronger than shock of 1651 .

1702 August 4*

-.--.--

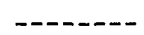

3,6

A strong earthquake caused extensive damage in Antigua.

1717 September 29 19:00 and 9:00

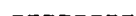

$1,3,6$ and $30^{*}$

Antigua damaged on September 29, destroyed September 30; loss of life was extensive. Large aftershock on October 3. Earthquakes accompanied by violent eruptions of Fuego.

1751 March 4

8:00*

$1,3,6$

Antigua damaged. Cathedral dome destroyed. 
NONINSTRUMENTAL DATA-Continued

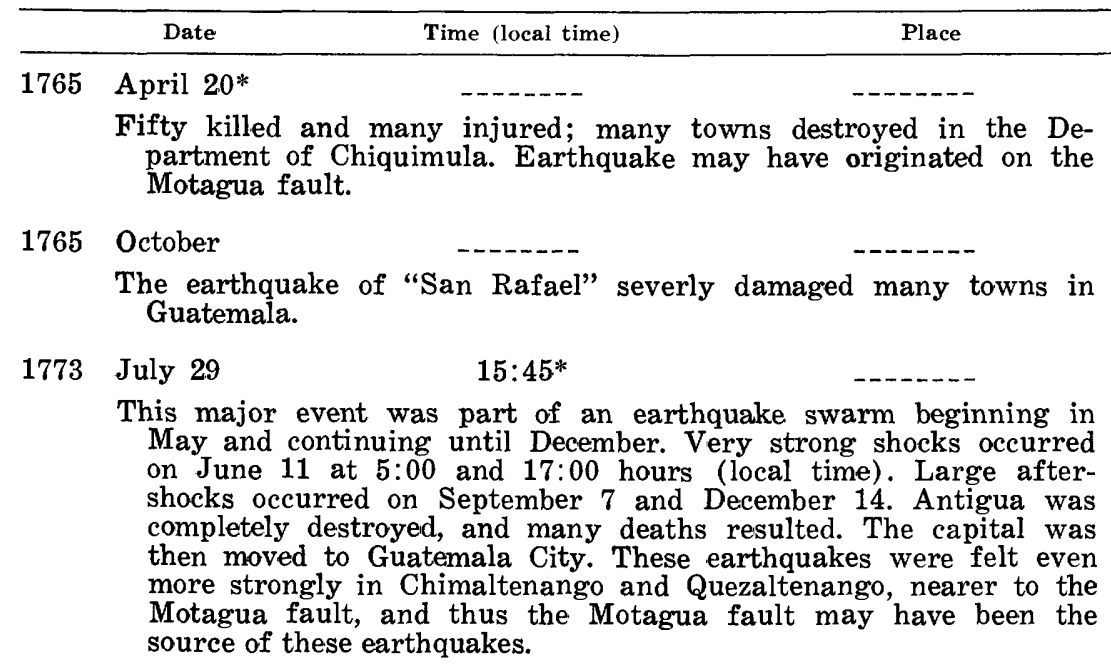

1830 April 1

-.......

(-

Swarm, similar to that of 1773 , destroyed many buildings in Antigua. Major aftershock on April 23.

1852 May 16

- - - - -

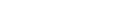

Damage in the vicinity of Quezaltenango.

February $9 *$

Major earthquake caused great alarm in Quezaltenango. Also strongly felt in Antigua and Amatitlán.

1855 January 1-26

Swarm with main events on the 18th and 26th. Damage at Cantel and Zunil.

December 8

$20: 15$

$-\cdots---$

Major earthquake near El Salvador-Guatemala border. Houses were shattered in Escuintla and Amatitlán. Tsunami at Acajutla, El Salvador.

1860 December 19*

-..-- -

Extensive damage to churches and homes in Escuintla. Aftershocks continued until December 31.

1861 August 27

-....-

Damage to homes and churches in Conquaco and Jalpatagua.

1862 December $19 *$

-.......

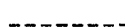

1,3

Antigua, Amatitlán, Escuintla. Tecpan, and neighboring towns were severely damaged. Damage to many churches and ancient constructions. Slight damage to old churches in Guatemala City; astronomical observatory reported tilt of $3^{\prime} 29^{\prime \prime}$.

1863 December 12

ed near Guatemala City, caused changes in

The earthquake, centered near Guatemala City, caused changes in flow of springs in the northern part of the city, and earth fractures opened in the areas of Jocotenango and El Bosque, causing much panic throughout the city.

June 12

15:00

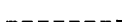

$1,3,6$

Extensive damage in the regions of Chiquimulilla, Cuilapa, and Ixhuatan. A later quake at 18:23 (local time) caused serious damage in Cuilapa. Aftershocks continued until the 23d.

1874 September 3

21:00*

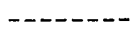

Antigua, Chimaltenango, and Patzicia were destroyed and 200 people killed. 
NONINSTRUMENTAL DATA-Continued

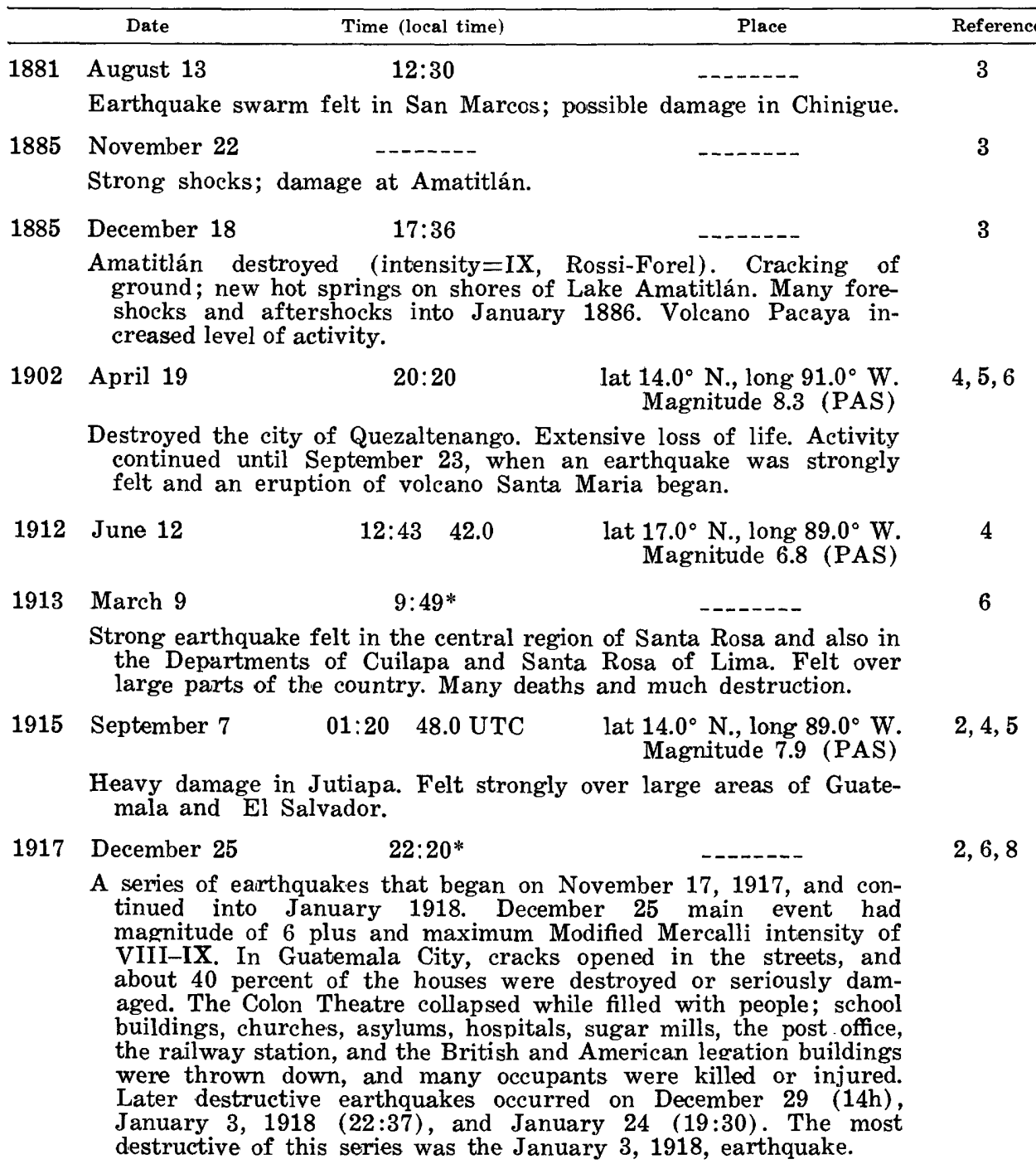

INSTRUMENTAL DATA

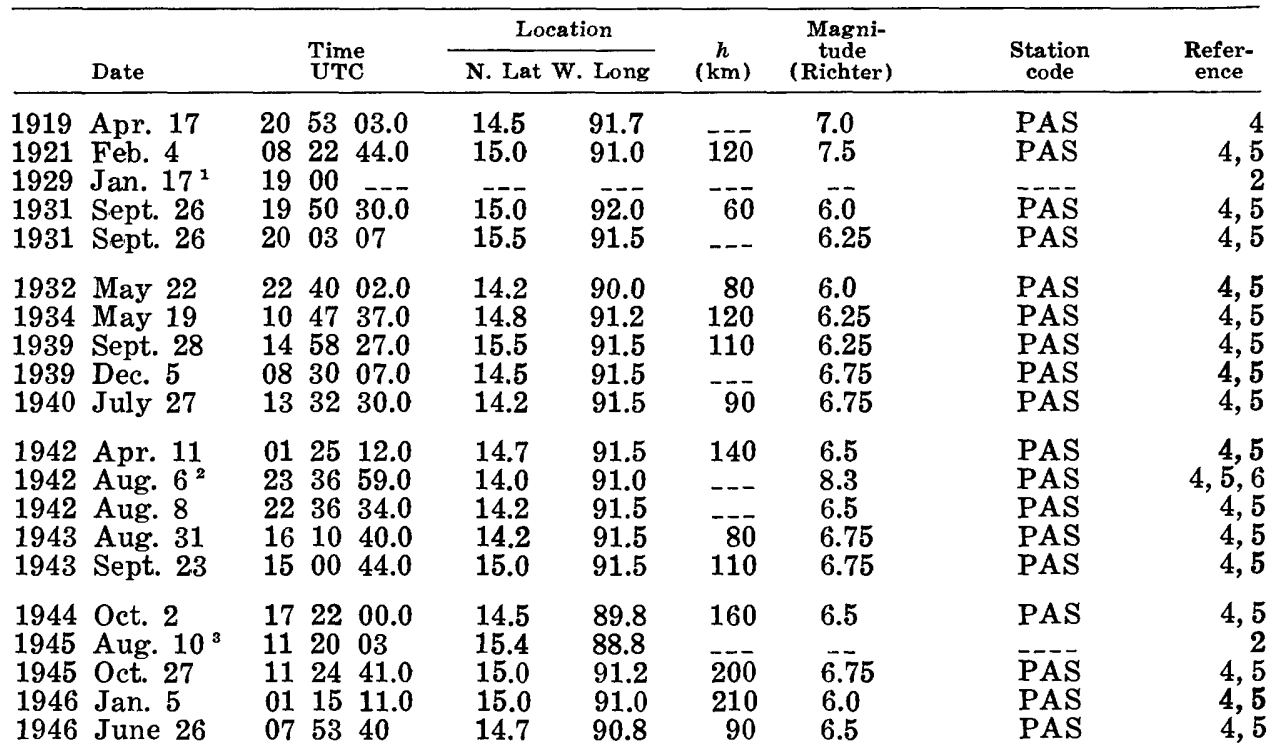


INSTRUMENTAL DATA-Continued

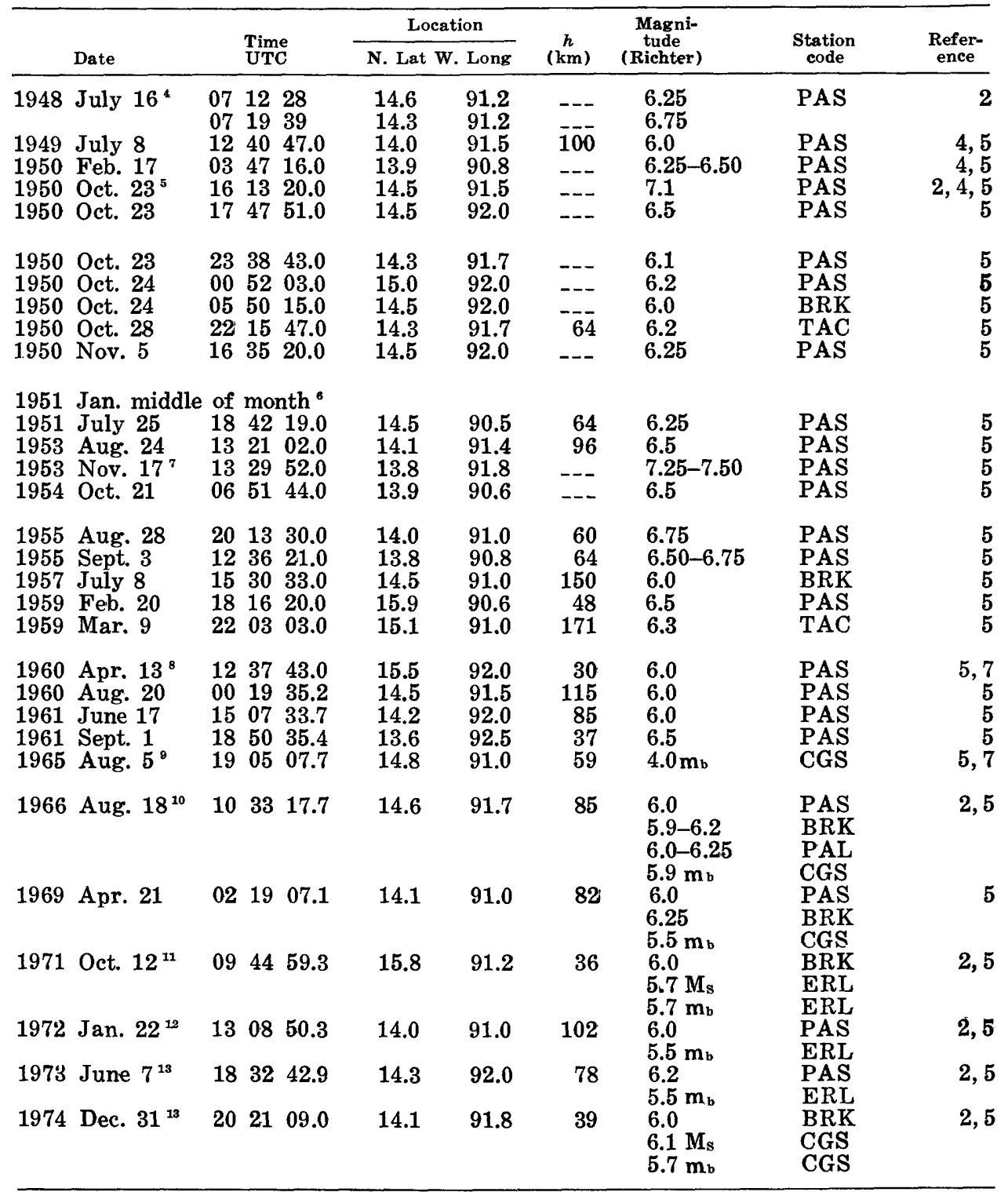

1 Considerable damage in Puerto Barrios.

2 Felt strongly throughout the central region of Guatemala; alarmed a large part of the population and

${ }_{3}$ Numerous earth cracks near Quiriguá and significant (moderate) damage in Quiriguá. Felt in Departments of Chiquimula, Zacapa, and part of Izabal.

4 People were tossed from their beds in Guatemala City.

5 Near the coast of Guatemala. Damage in San Marcos area.

A series of strong earthquakes in the region of Ixhuatan in the Department of Santa Rosa that caused considerable damage in the area.

T Near the coast of Guatemala.

8 Guatemala-Mexico border; one killed, 14 ingeter

9 One killed and four injur

10 Felt at San Salvador.

11 Mexico-Guatemala region.

12 Felt (intensity V) at San Salvador, El Salvador.

${ }^{13}$ Felt in Guatemala City area.

References :

(1) Brigham (1887)

(2) Seismological Notes, Seismological Society of America Bulletin, v. 5-15, v. 8-18, v. 38-48.

(3) Montessus de Ballore (1888).

(4) Gutenberg and Richter (1954).

(5) NOAA Hypocenter Data File (1976, written commun).

(6) Vassaux (1969).

(7) U.S. Earthquakes $(1960,1965)$

(8) Claudio Urrutia E. (1976, written commun). 


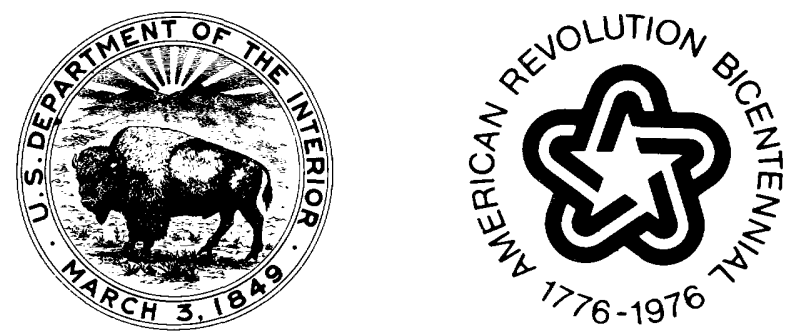

\section{COVER PHOTOGRAPH:}

Surface fractures along the Motagua fault crossing a soccer field at Gualán, Department of Zacapa. The fractures, formed during the February 4, 1976, earthquake, show left-lateral strike-slip displacement; the ground on the right side of the photograph moved west (away from the viewer), and the ground on the left side of the photograph moved east (toward the viewer). Superimposed on this picture is the trace of the horizontal long-period low-gain seismogram, east-west component, recorded at Albuquerque Seismological Center, Albuquerque, New Mexico, U.S.A. Epicentral distance is $2,778 \mathrm{~km}$. 